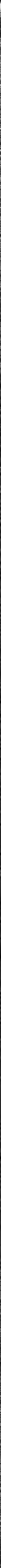




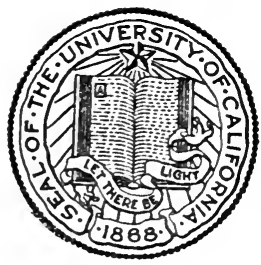

THE LIBRARY OF THE UNIVERSITY OF CALIFORNIA

GIFT OF

Mirs. Edwin Grabhorn

The Bancroft Library

University of California - Berkeley 
Digitized by the Internet Archive in 2007 with funding from Microsoft Corporation 




\section{A BIBLIOGRAPHY}

\section{$\mathrm{OF}$}

OLIVER WENDELL HOLMES 




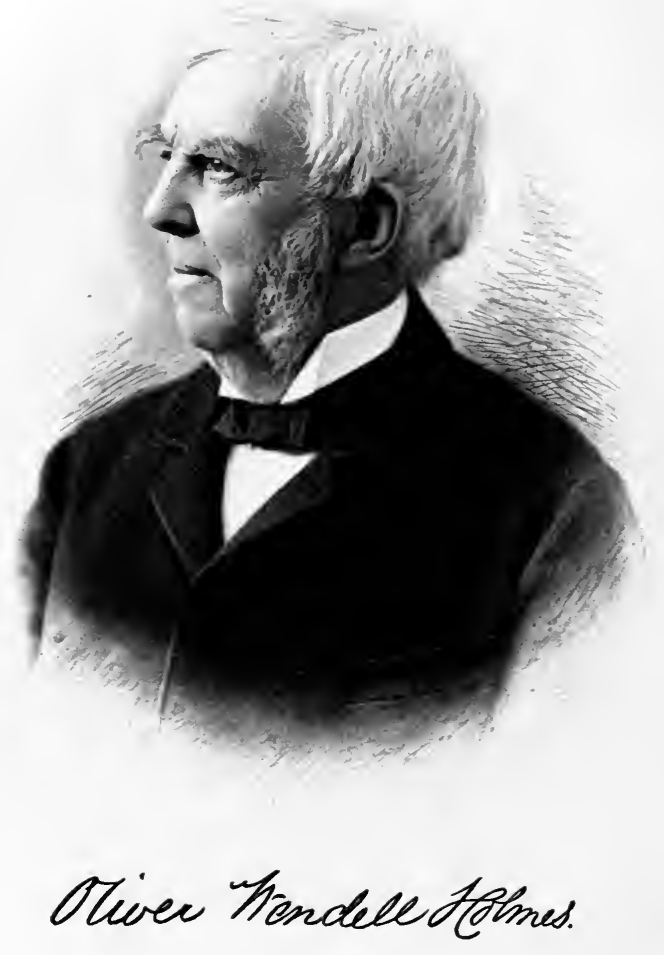






\section{A BIBLIOGRAPHY OF}

\section{OLIVER WENDELL HOLMES}

COMPILED BY GEORGE B. IVES

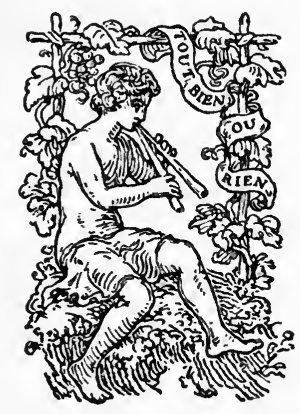

BOSTON AND NEW YORK HOUGHTON, MIFFLIN AND COMPANY MDCCCCVII 
COPYRIGHT 1907 BY HOUGHTON, MIFFLIN \& CO. ALL RIGHTS RESERVED

FIVE HUNDRED AND THIRTY COPIES PRINTED NUMBER 34\% 


\section{PREFACE}

"Des communications et des rencontres, voilà ce qui arrive à tout lexicographe en quête de matériaux," wrote Littré by way of introduction to the third supplement to his great dictionary. With the substitution of a word the observation will apply with equal force to one in quest of material for the bibliography of an author so prolific as Dr. Holmes in "occasional" prose as well as verse. The compiler of this volume early abandoned all hope of achieving completeness, even before he was warned by one who knew whereof he spoke that he had undertaken a "supernatural" task. He has finally become convinced that, no matter how long the book may be withheld from the press, there will be no end to the "communications and discoveries ;" the Appendix contains those which have come to hand since the pages were made up, and which it was impossible to incorporate in the text.

The general arrangement of the bibliography is substantially the same as that adopted by Mr. Cooke in his Bibliography of Lowell.

I. A Chronological List of Titles, accompanied by page references. This list is extended to include the more important volumes in which some of Dr. Holmes's works are printed in conjunction with the work of other writers.

II. An Alphabetical List of Single Works. This list has been extended by the necessity of introducing a large number of cross-references. So many poems written for special occasions have never received any distinguishing titles, and are printed in the collections simply as "Songs," "Poems," or "Hymns," that it is not easy to find any particular one without the aid of a cross-reference. Again, a number of the poems, especially the earlier ones, were originally pub- 


\section{[ vi ]}

lished under different titles from those which they now bear, and a complete list must necessarily include both.

In searching for unpublished matter in the periodicals and "Annuals" of the years between Dr. Holmes's graduation and the publication of his first volume of poems (1836), the compiler remembered a passage in a letter to Phineas Barnes, quoted by Mr. Morse, in his biography of Dr. Holmes: "By the way, if you find any floating scraps with O. W. H. to the tail of them, set them down to the owner and, I believe, the only one, of those preposterous initials." In this way he was able to fix the original appearance of some, even of the acknowledged poems, which the careful editor of the Cambridge Edition had failed to place. The purpose has been to give, so far as possible, in connection with each item:-

1. Particulars as to its first appearance in print.

2. If it first appeared elsewhere than in a bound volume, the title and date of publication of such volume in which it was first printed, if at all.

3. Its first appearance in a volume of Dr. Holmes's collected works.

In some special cases further details are given; and when it has come to the compiler's knowledge that a poem was printed in the form of a leaflet, or broadside, for distribution on the "occasion" for which it was written, or for any other purpose, that fact also is noted. Such printings are, in the eye of the collector, first editions, and are prized accordingly.

Unfortunately, for the purposes of the bibliographer, at least, there is no possibility of identifying Dr. Holmes's earliest original works. His own statements on the subject are not illuminating. In the "Autobiographical Notes" printed by Mr. Morse, ${ }^{2}$ he says, "I have often been asked what were the first verses I printed. I can't be quite certain on this point; but of one thing I am quite certain, that, so far as I know, no vestige of talent is found in any one of ${ }^{2}$ Vol. i, p. 71.

2 Vol. i, p. 47. 


\section{[ vii ]}

them." And in the letter to Mr. John O. Sargent of Feb. 19, 1878, accompanying the famous sonnets written for the anniversary of the Harvard Club of New York: "May I venture to remind you, Mr. President, that it is nearly fifty years since you, as Editor of a College Magazine, gave a kindly welcome to the earliest printed verses known as coming from my pen?" The reference is, of course, to the Collegian, and perhaps the qualifying phrase, "known as coming from my pen," may reconcile it with the following passage of a letter to Phineas Barnes, written in March, 1828, fifty years earlier, while Holmes was still an undergraduate at Harvard: "I smoke most devoutly, and sing most unmusically, have written poetry for an Annual, and seen my literary bantlings swathed in green silk and reposing in the drawing-room." 1 Thus far no one has succeeded in discovering an "Annual" bound in green silk, of a sufficiently early date to meet the requirements of this allusion, although some of those who have been interested enough to follow it up, have thought that they detected Dr. Holmes's hand in different poems in the Token for 1828 and 1829.

It is certain, however, that he was the author of two poems which were composed and delivered during the year 1829, but of which neither, in all likelihood, was ever printed. On July 14, Class Day, Holmes "delivered a humorous and characteristic poem, the chief objection to which was its brevity." Such is the record of the Secretary of the Class of $1829 ;^{2}$ and Mr. Lowell, in his article on Class Day for the Harvard Book, ${ }^{3}$ quotes the diary of the Rev. George Whitney of Roxbury with respect to this Class Day of 1829 as follows:-

1 Morse, vol. i, p. 55.

2 The compiler cannot adequately express his regret that, under the conditions governing the deposit in the Library of Harvard College of the absolutely unique volume containing the records of the famous Class, as kept for sixty years by the Secretary, Mr. Samuel May, he is unable to draw upon it for material which would add immeasurably to the interest of this work. It is occasionally referred to as authority for some fact for which there is no other authority.

${ }^{3}$ Cambridge, 1875, vol. ii, p. 165. 


\section{[ viii ]}

“His [Holmes's] poem was very happy and abounded in wit. Instead of a spiritual muse he invoked for his goddesses the ladies present, and in so doing he sang very amusingly of his "hapless amour with too tall a maid.",

Again, at Commencement, we have, in addition to the Class records, the testimony of Rev. John Pierce of the Class of 1793, in his diary, that "Holmes gave much delight in a poem without a subject." 1 .

It is probable that the poem printed, under the title "Banditti," in the New England Galaxy early in 1830, and reprinted under the same title, in the same year, in the Gleaner, is the earliest production of Dr. Holmes's of which we can be absolutely sure. It is familiar to all readers under the title "The Music-Grinders."

III. A Chronological List of Single Publications.

Beginning with the Harbinger, in which seventeen of Dr. Holmes's poems, all of which save one ${ }^{2}$ had been previously printed, in various periodicals and annuals, were "collected," an attempt has been made to include all the important editions, at least, of each successive publication of Dr. Holmes. Recourse has been had to the Library of Harvard College, the Boston Public Library, the Boston Athenæum, and the Boston Medical Library; also to the Library of Congress, and, lastly, to the Catalogue of Printed Books in the British Museum. As to the last-named authority, the compiler feels bound to say that he is not altogether satisfied as to the extraordinary number of editions of various works said to have been issued by Messrs. Routledge, most of which are given in the Appendix.

In this list only those separate issues of individual poems

1 Proceedings of the Massachusetts Historical Society, 2d series, vol. 5, p. 200. Extracts from Mr. Pierce's diary have been published at intervals by the Society. See under "Poetry: a Metrical Essay" and "The Pilgrim's Vision."

2 “The Dying Seneca." It probably had been printed elsewhere, but has not been discovered. 


\section{[ix ]}

are included which seem to have been printed with some idea of permanence.

IV. Selections and Compilations.

This list has been extended somewhat beyond its natural intent, in order to give, in conjunction with that immediately preceding, prominent position to every book (not including periodicals, or reports of proceedings on special occasions) in which any work of Dr. Holmes was first printed.

\section{Letters.}

VI. Contributions to the Atlantic Monthly.

The foregoing lists are intended to include, in some form, mention of everything written by Dr. Holmes. Those which follow represent the compiler's endeavors to collect what has been written about him and his work.

I. Biographies, including a list of bibliographies, of which only those of Mr. Foley, Mr. Arnold, and Mr. Kennedy ${ }^{1}$ deserve special mention. None of these were published separately.

II. List of books and articles of which the authors are known, arranged alphabetically by the authors', names.

III. Chronological List of anonymous articles.

As to the last two lists, the compiler regrets that it was impracticable, without extending them beyond measure, to indicate, except in rare instances, the comparative importance of the works enumerated. Many would have been omitted except for his reluctance to attempt to discriminate.

IV. Poems.

The volume closes with a list of sales at auction. Even a cursory examination will show how unreliable such sales are in fixing the value of any particular volume; for the prices obtained are not only influenced by considerations of sentiment and association, but vary mysteriously accord-

${ }^{1}$ In his Life of Holmes. 


\section{$[\mathbf{x}]$}

ing to the dates of the various sales, and, to some extent, according to the names of the owners of the volumes sold.

If he has fallen far short of completeness, the compiler ventures to hope that his work will, at least, be found to be free from serious errors, although there may be occasional inconsistencies in the arrangement of material. To remedy this defect so far as possible, and to direct attention to the miscellaneous items of information which are scattered through the various lists and to which neither alphabetical nor chronological arrangement gives a clue, an index has been added. It does not pretend to be exhaustive, or to be arranged on any scientific plan, but it is hoped that it may measurably serve the purpose indicated.

The compiler is glad to acknowledge his indebtedness to Mr. Charles Albert Read, of the Harvard Library, for valuable assistance in collecting material, especially data of magazine articles and other works concerning Dr. Holmes; to Miss Annie L. Sinclair, of the Library of Congress at Washington, for descriptions of editions of Dr. Holmes's works other than those issued by his authorized publishers; and to Mr. James F. Ballard, of the Boston Medical Library, for courteous and willing coöperation in his investigations there. $\mathrm{He}$ is also under great obligation to Mr. Justice Holmes for memoranda relating to certain editions in his library, of which he has obtained no information from any other source. Mr. Luther S. Livingston, in addition to his generous assistance, acknowledged elsewhere, in connection with the record of auction sales for 1905-06, has very kindly furnished bibliographical material which has made it possible to add considerably to the list of volumes containing letters of Dr. Holmes; and Mr. Patrick Kevin Foley, with the most unselfish and hearty good-will, has supplied valuable information and suggestions which are gratefully acknowledged. Thanks are due also to Mr. George Blatchford, of Pittsfield, and to the family of the late Mr. J. E. A. Smith, for their generous permission to print those of the 
"Berkshire poems" of Dr. Holmes, which were first published in Mr. Smith's "The Poet among the Hills;" also to Dr. James Jackson Putnam for permission to print the verses to Dr. James Jackson on his eightieth birthday.

Mrs. J. Chester Chamberlain, of New York, has, with the utmost courtesy and kindness, supplied descriptions of two very rare works, - "New England's Master-Key" and a Lecture of 1863 , - the only known copies of which are in the great collection of the late Mr. Chamberlain, whose untimely death in the prime of life and in the midst of a career of great usefulness and promise is lamented not by collectors alone. The value of this work to those persons to whom, if to anybody, it can have value is greatly increased by the inclusion of such material.

Mr. Stephen H. Wakeman, of New York, whose collection of works by and concerning the New England group of authors is very extensive and complete, kindly allowed the compiler to inspect his valuable Holmes collection; the most notable result of that permission is the description of the unique "Lecture on the Poetry of the War," of which only two copies are known to have been printed. In addition to this, however, the compiler is indebted to Mr. Wakeman for his knowledge of the existence of a number of poems in the shape of separate leaflets, and of the reprint of the Atlantic article on Hawthorne in that author's "Pansie;" also for the opportunity to inspect the "Verses from the Island Book," for copies of the "Prelude" to that volume, and of the curious versions of the passage from "The Old Player," printed in the Recreations of the Rabelais Club; and for much other information which was unobtainable elsewhere, all of which is gratefully acknowledged.

In conclusion the compiler takes the opportunity to say that his investigations have satisfied him that collectors outside of New England are rapidly acquiring all that is most valuable from their standpoint in the way of editions and manuscripts of the group of authors to whom that section of the country owes its literary prestige. 



\section{CONTENTS}

Chronological List of Dr. Holmes's Works - 1 Alphabetical List of Single Titles

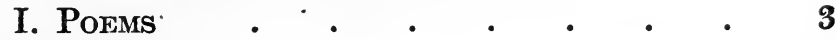

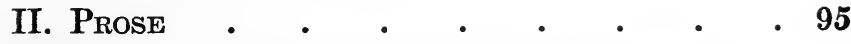

Chronological List of Single Publications

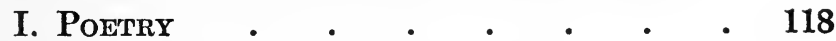

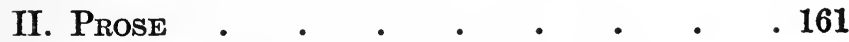

COLlected Works . . . . . . . 200

Selections and Compilations $\quad . \quad$. $\quad .202$

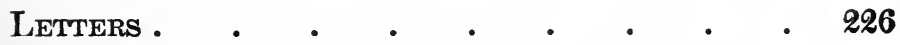

Dr. Holmes's Contributions to the Atlantic

Monthly • • • • • • • • . 236

Biography and Criticism

I. Biographies • • • • • $\quad 243$

Bibliographies . . . . . . 245

II. Signed Essays, Reviews, etc. • • 246

III. Essays, Reviews, and other Anonymous

Articles, arranged in Chronological

ORDER • . . . . . . . 263

IV. Poems • • • .

Record of Sales at Auction . . . . 287

Manuscripts . . . . . 302

APPENDIX.$\quad \cdot \quad \cdot \quad \cdot \quad \cdot \quad \cdot \quad \cdot \quad \cdot 305$

INDEX $. \quad . \quad . \quad . \quad . \quad . \quad . \quad . \quad .317$ 



\section{BIBLIOGRAPHY}





\section{CHRONOLOGICAL LIST OF DR. HOLMES'S WORKS}

The figures opposite the titles refer to the pages upon which the various editions of the respective publications are described. The list includes, besides Dr. Holmes's own publications, the most important works of which his contributions form only a part of the contents.

1830. The Collegian 202

The Gleaner 205

1833. The Harbinger 118

1836. The Laurel 206

Poems 119

1838. Boylston Prize Dissertations, 1836-1837 161

1842. Homœopathy, and its Kindred De- *

lusions 162

1843. The Contagiousness of Puerperal Fever 162

1846. Poems, London 123

Urania: a Rhymed Lesson 125

1849. Poems 125, 127

1850. Astræa: the Balance of Illusions 129

Dedication of Pittsfield Cemetery 130

1852. Poems, London 130

1854. Songs of the Class of 1829 132, 133, 134, 135 The New Eden 136

1856. Oration before the New England Society 164

1858. The Autocrat of the Breakfast-Table 165, 314

1859. The Promise

136

1860. The Professor at the Breakfast-Table 171, 315

Currents and Counter-Currents in Medical Science

174

1861. Currents and Counter-Currents in Medical Science, with other Addresses and Essays

Elsie Venner

Vive la France

175

176,315

137

1862. Songs in Many Keys

137

Poems, Blue and Gold Edition $\quad 141$ 


\section{[2]}

1863. Oration delivered before the City Authorities of Boston, July 4th

Lecture

New Englanu's Master-Key

1864. Soundings from the Atlantic

1865. Poetry of the War

Humorous Poems

208

Verses from the Island Book

207

1867. The Guardian Angel

181,316

1869. History of the American Stereoscope

1871. Mechanism in Thought and Morals

182

182

1872. The Claims of Dentistry

183

The Poet at the Breakfast-Table

1874. Professor Jeffries Wyman

183,316

1875. Songs of Many Seasons

Grandmother's Story of Bunker Hill Battle

185

142

1877. Poems, Household Edition

144

1879. John Lothrop Motley. A Memoir The School-Boy

146

185

150

1880. Jonathan Edwards

188

The Iron Gate, and Other Poems 151

1881. Poems, Handy Volume Edition 152

1883. Medical Essays, 1842-82 189

Pages from an Old Volume of Life $\quad 190$

1885. Ralph Waldo Emerson 191

A Mortal Antipathy 192, 316

The Last Leaf 153

1887. Our Hundred Days in Europe 192

Before the Curfew, and Other Poems 155

1891. Tribute to Henry J. Bigelow, M. D. 195

Over the Teacups 196

Works, Riverside Edition 200

1892. Works, Standard Library Edition 200

1892-96. Works, Artists' Edition 201

The One-Hoss Shay, etc. $\quad 157$

Dorothy Q., etc. 158

1895. Poems, Cambridge Edition 158

1899. Poems, Cabinet Edition 160

1900. Works, Popular Edition 201

1904. Works, Autocrat Edition 201 


\section{ALPHABETICAL LIST OF SINGLE TITLES}

IN this list those titles which are not included in the collected editions of Dr. Holmes's Works are preceded by an asterisk; those which have been published separately are printed in small capitals.

I

\section{POEMS}

"Ad Amicos" (For the Class Meeting, Jan. 6, 1876)

Atlantic Monthly, March, 1876, vol. 37, pp. 314-315.

Poems, Household Edition, 1877.

Additional Songs and Poems of the Class of 1829, 1881, pp. 165-168.

Ad Sodales (Written for the Class Meeting, Jan. 6, 1870)

Songs of Many Seasons, 1875.

Additional Songs and Poems of the Class of 1829, 1881, pp. 130-135.

Printed in Songs of Many Seasons, and in all subsequent collected editions, under the title "Even-Song." The records of the Class aver that Dr. Holmes had given it as a title "Sat prata biberunt," and had addressed it Ad Sodales.

Address for the Opening of the Fifth Avenue Theatre (New York, Dec. 3, 1873)

Songs of Many Seasons, 1875.

See Appendix, p. 305, infra.

Estivation (An Unpublished Poem by my late Latin Tutor)

Atlantic Monthly, Sept., 1858, vol. 2, pp. 500-501, in the "Autocrat."

Autocrat of the Breakfast-Table, 1858, p. 307.

Songs in Many Keys, 1862.

After a Lecture on Keats

Songs in Many Keys, 1862. 


\section{[4]}

After a Lecture on Moore

Songs in Many Keys, 1862.

After a Lecture on Shelley

Songs in Many Keys, 1862.

After a Lecture on Wordsworth ${ }^{1}$

Songs in Many Keys, 1862.

See "A Vision of the Housatonic."

After the Buria'.

Boston Weekly Globe, Tuesday, Sept. 27, 1881. (Garfield Memorial Number.)

The Poets' Tribute to Garfield. The collection of poems for the Boston Globe, 1881, pp. 28-30.

See "On the Death of President Garfield."

After the Curfew (Read at the Class Meeting, Jan. 10, 1889)

Latest Poems of the Class of 1829, 1890, pp. 227-229.

Atlantic Monthly, Feb., 1890, vol. 65, pp. 242-243, in “ Over the Teacups."

Over the Teacups, 1890, pp. 69-70.

Poems, Riverside Edition, 1891.

This was the last of the long and wonderful list of Class poems. There was but one more "regular" meeting, - on January 9 , 1890 , - when Dr. Holmes and only two other members of the class met at the Parker House; "for the first time in forty full years Holmes had come without a poem."

After the Fire (Boston, Nov. 30, 1872)

Atlantic Monthly, 1873, vol. 31, pp. 96-97

Songs of Many Seasons, 1875.

After-Dinner Poem, An (Phi Beta Kappa, Cambridge, 1843)

Poems, Household Edition, 1877.

Originally printed in Graham's Magazine and in Poems (London), 1846, under the title "Terpsichore," which see.

1 The four poems last named, together with a fifth, "At the Close of a Course of Lectures," were read as postludes to a course on English Poetry of the Nineteenth Century, delivered before the Lowell Institute, Boston, in 1853, and never published. 
Agassiz, Farewell to

See "A Farewell to Agassiz."

Agnes

Songs in Many Keys, $1862 .{ }^{1}$

"Liberty was granted to Dr. Holmes, at his written request, to make certain extracts from the manuscript diary of Sir Henry Franckland, for the illustration of a narrative poem written by himself." - Proceedings of Massachusetts Historical Society, Sept. 13, 1860, vol. 5, p. 63.

\section{Album Verses}

Atlantic Monthly, Nov., 1857, vol. 1, p. 54, in the "Autocrat." ${ }_{2}$ Autocrat of the Breakfast-Table, 1858, pp. 18-19.

Poems, Household Edition, 1877.

Alexis, Grand Duke, of Russia

See "At the Banquet to the Grand Duke Alexis," and "A Welcome to the Grand Duke Alexis."

All Here. 1829-1867 (Written for the Class Meeting, Jan. 10, 1867)

Atlantic Monthly, March, 1867, vol. 19, pp. 323-324.

Songs and Poems of the Class of 1829, 1868, pp. 90-92.

Songs of Many Seasons, 1875.

Alumni of Harvard College, Meeting of the

See "Meeting of the Alumni," etc.

America to Russia (Read by Hon. G. V. Fox at a dinner given to the Mission from the United States, St. Petersburg, Aug. 5, 1866)

Russian Account of the Official Mission of G. V. Fox to Russia in 1866. Translated by S. N. Buynitzky, 1867, p. 18. Songs of Many Seasons, 1875.

"Early in 1866," says Mrs. Hughes, ${ }^{3}$ " Mr. Fox, still Assistant

1 In a note to this poem Dr. Holmes speaks of its having been published June 10, 1861, but the compiler has been unable to find any publication containing it of an earlier date than this volume, which was copyrighted in 1861 , and actually issued late in that year.

2 There printed without title.

3 Sarah Forbes Hughes: Letters and Recollections of John Murray Forbes, 1899, vol. ii, pp. 159-160. 


\section{[6]}

Secretary of the Navy, was sent by the United States Government, in a monitor, to Russia, to offer to the Czar our country's congratulations on the freeing of the serfs. When this was in contemplation, it occurred to my father that a slightly different touch might be given to the affair by some verses 'with a good ring to them;' and accordingly, at his suggestion, his kind friend, Dr. Oliver Wendell Holmes, wrote for this occasion the ode beginning:

\section{' Though watery deserts hold apart}

The worlds of East and West.'

"Mr. Fox, after crossing the ocean successfully in the small monitor, ... arrived duly in Russia; the poem was read to the Czar and translated by the court poet, and was a great success."

American Academy Centennial Celebration (May 26, 1880)

Memoirs of the American Academy of Arts and Sciences, Centennial Volume (vol. 11, part i), 1882, pp. 11-13. ${ }^{1}$

The Iron Gate, and Other Poems, 1880.

American Medical Association, Meeting of the (1853)

See "Poem for the Meeting, etc.," and ["A Sentiment"].

Andrew, Governor, Hymn for the Inauguration of

See "Hymn for the Inauguration," etc.

Angel-Thief, The (Read at the Class Meeting, Jan. 5, 1888)

Before the Curfew, and Other Poems, 1888.

Latest Poems of the Class of 1829, 1890, pp. 225-226.

A[ngier], J[oseph], 1871

See "Our Sweet Singer."

Appeal for the Old South, An

Poems, Household Edition, 1877.

See "The Brave Old South."

1 The poem was read during the exercises at the Old South Church, and was prefaced by some humorous remarks, printed on p. 11 of the volume. 


\section{[7]}

Archbishop, The, and Gil Blas

Atlantic Monthly, Aug., 1880, vol. 46, pp. 205-206.

The Iron Gate, and Other Poems, 1880.

See "A Dialogue. Senex - Juvenis."

Army Hymn

Atlantic Monthly, June, 1861, vol. 7, p. 757.

A Discourse before the Ancient and Honorable Artillery Company on its ccxxirr Anniversary, June 3, 1861; by S. K.

Lothrop, D.D., pp. 59-60.

Chimes of Freedom and Union, 1861, p. 14.

Monthly Journal of the American Unitarian Association, Oct., 1861 (army number), vol. 2, p. 452.

Songs in Many Keys, 1862.

Astraa: the Balance of Illusions (Phi Beta Kappa, Yale, 1850)

Poems, London, 1852.

Poems, Cambridge Edition, 1895.

The original ms. of "Astræa," $32 \mathrm{pp.} \mathrm{4to,} \mathrm{signed,} \mathrm{dated}$ Aug. 4, 1850 (bound in half morocco), brought $\$ 111.00$ at the Kennedy Sale, April, 1904.

[At a Birthday Festival] To J. R. Lowell

Atlantic Monthly, April, 1859, vol. 3, p. 493, in the "Professor."

Professor at the Breakfast-Table, 1859, pp. 96-97.

Songs in Many Keys, 1862.

First printed with title in last-named volume.

At a Dinner to Admiral Farragut (July 6, 1865)

Songs of Many Seasons, 1875.

At a Dinner to General Grant (July 31, 1865)

Songs of Many Seasons, 1875.

At a Meeting of Friends (Aug. 29, 1859)

Poems, Household Edition, 1877.

In Mr. Longfellow's Journal under the above date is the following entry: "Drove up to town to dine with Dr. Holmes's friends on his fiftieth birthday. Felton presided. A delightful dinner. 


\section{[8]}

Holmes made a charming little speech with some verses at the end to round it off." - S. Longfellow's Life of H. W. Longfellow, vol. ii, p. 393, Standard Library Edition.

\section{At my Fireside}

Before the Curfew, and Other Poems, 1888, p. iii, as Prelude.

At the Atlantic Dinner (Dec. 15, 1874)

Poems, Household Edition, 1877.

At the Banquet to the Chinese Embassy (Aug. 21, 1868)

Reception and Entertainment of the Chinese Embassy by the City of Boston, 1868, pp. 41-42.

Songs of Many Seasons, 1875.

At the Banquet to the Grand Duke Alexis (Dec. 11, 1871)1

His Imperial Highness the Grand Duke Alexis in the United States of America during the winter of 1871-72 (1872), p. 97.

Songs of Many Seasons, 1875.

At the Banquet to the Japanese Embassy (Aug. 2, 1872)

Songs of Many Seasons, 1875.

At the Close of a Course of Lectures

Songs in Many Keys, 1862.

See note on p. 4, supra.

At the Pantomime (18-. Rewritten 1874)

Songs of Many Seasons, 1875.

The last four stanzas are printed in "Over the Teacups," 1890, pp. 198-199 (Atlantic Monthly, July, 1890, vol. 66, p. 103).

\section{At the Papyrus Club}

The Iron Gate, and Other Poems, 1880.

\section{At the Saturday Club}

Atlantic Monthly, Jan., 1884, vol. 53, pp. 68-71.

Before the Curfew, and Other Poems, 1888.

1 This poem is dated Dec. 9 in all editions of the Poems, but the banquet actually took place on the 11th. 
At the Summit (To Harriet Beecher Stowe on her seventieth birthday, June 14, 1882)

Atlantic Monthly, Aug., 1882, vol. 50, pp. 164-165.

Before the Curfew, and Other Poems, 1888.

At the Turn of the Road

Atlantic Monthly, Oct., 1890, vol. 66, p. 547, in "Over the Teacups."

Over the Teacups, 1890, pp. 288-289.

Poems, Riverside Edition, 1891.

At the Unitarian Festival (March 8, 1882)

Before the Curfew, and Other Poems, 1888.

\section{Aunt Tabitha}

Atlantic Monthly, March, 1872, vol. 29, p. 349, in the "Poet."

Poet at the Breakfast-Table, 1872, pp. 102-103.

Songs of Many Seasons, 1875.

Ave

Atlantic Monthly, April, 1884, vol. 53, pp. 456-457.

Illustrated Poems, 1885, pp. x-xi, as Prelude. Avis

Atlantic Monthly, Dec., 1858, vol. 2, pp. 893-894, in "The Autocrat Gives a Breakfast to the Public."

Songs in Many Keys, 1862.

An autograph ms. of "Avise" [sic] on 3 quarto pages, with an explanatory note, also in autograph, on a separate page, signed in full, brought $\$ 36.00$ at the Williamson Sale in March, 1904, and $\$ 11.00$ at the Wendell Sale, in May, 1905. See also p. 97, infra.

Ballad of the Boston Tea-Party, A

Proceedings of the Massachusetts Historical Society, Dec. 16, 1873, vol. 13, pp. 202-204.

Proceedings at a Special Meeting of the Mass. Hist. Soc., Dec. 16, 1873, being the 100th Anniversary of the destruction of the tea in Boston Harbor, 1874, pp. 56-58. Atlantic Monthly, Feb., 1874, vol. 33, pp. 219-221.

Songs of Many Seasons, 1875.

Ballad of the Oysterman, The

The Amateur, July 17, 1830, no. 3, pp. 37-38. 
The Harbinger (1833), pp. 36-38.:

Poems, 1836.

\section{Banditti}

New England Galaxy, 1830.

The Gleaner, or Selections in Prose and Poetry from the Periodical Press, 1830, pp. 33-35.

See "The Music-Grinders."

Banker's Dinner, The

Songs in Mary Keys, 1862.

Poems, Household Edition, 1877.

See "The Banker's Secret," "Each Heart has its own Secret," and "Readings over the Teacups."

Banker's Secret, The

Poems, Riverside Edition, 1891, in "Readings over the Teacups."

Poems, Cambridge Edition, 1895.

Originally printed under the title "The Banker's Dinner," as one of the group, Pictures from Occasional Poems, in Songs in Many Keys, 1862, and still so printed in the Household Edition. See "Each Heart has its own Secret."

Before the Curfew (Read at the Class Meeting, Jan. 5, 1882)

Atlantic Monthly, March, 1882, vol. 49, pp. 386-388.

Before the Curfew, and Other Poems, 1888.

Latest Poems of the Class of 1829, 1890, pp. 204-208.

Printed under the title "In the Twilight," in Poems, Riverside Edition, 1891, and in the Cambridge Edition, 1895.

Bells, The

Songs in Many Keys, 1862.

See note to "Spring."

* Beni-Israel

Gifts of Genius, a Miscellany of Prose and Poetry, 1859, pp. 260-263.

Berkshire Festival, Lines recited at the

See "Lines recited at the Berkshire Festival." 


\section{[11]}

Bill and Joe

Atlantic Monthly, Sept., 1868, vol. 22, pp. 313-314.

Songs of Many Seasons, 1875.

Additional Songs and Poems of the Class of 1829, 1881, pp. 121-123.

"Although not written for a meeting of the Class, yet as the Class of 1829 is the subject of them, and one of the Class their author, these lines belong here." Dr. Holmes read the poem to the Class in Jan., 1869, and thereafter it 'was "one of the Class Poems unmistakably and forever." Since 1877 it has stood, without date, at the head of the "Poems of the Class of 1829," in all collected editions.

Birthday of Daniel Webster (Jan. 18, 1856)

The Seventy-Fourth Anniversary of the Birthday of Daniel

Webster, 1856, pp. 49-51.

Songs in Many Keys, 1862.

Birthday Tribute, A. To J. F. Clarke (April 4, 1860)

Memorial of the Commemoration by the Church of the Disciples of the 50th Birthday of their Pastor, James Freeman Clarke, 1860, pp. 19-20.

Songs in Many Keys, 1862.

Bonaparte, August 15, 1769. - Humboldt, September 14, 1769

Leaflet, oblong $8 \mathrm{vo}$.

Address delivered on the Centennial Anniversary of the birth of Alexander von Humboldt, etc., by Louis Agassiz. With an Account of the Evening Reception, 1869, pp. 86-88.

Atlantic Monthly, Dec., 1869, vol. 24, pp. 637-638.

"Last week we had a Humboldt celebration, or rather two, in Boston. ... . Of course I wrote a poem, which I had the wonderful good sense to positively refuse delivering in Music Hall after the long Address of Agassiz, but read at the Soirée afterwards. I thought well of it, as I am apt to, and others liked it. Applaud my abstinence in not sending it to you." Holmes to Motley, Sept. 26, 1869, in Morse's Life and Letters of O. W. H., vol. ii, p. 184.

See "Humboldt's Birthday." 
Boston Church Bells

The Boston Book, 1850, pp. 9-10.

An extract from "Urania, a Rhymed Lesson." A portion of the same extract appears in Poetry of the Bells, collected by S. Batchelder, Jr., 1858, p. 64. See "A Sabbath in Boston."

Boston Common - Three Pictures (1630, 1774, 186-) (For the Fair in aid of the Fund to procure Ball's Statue of Washington)

Leaflet, 4to: pp. 4, 1859. See Appendix, p. 305, infra.

Songs in Many Keys, 1862.

Boston to Florence (Sent to the "Philological Circle" of Florence for its meeting in commemoration of Dante, Jan. 27, 1881, anniversary of his first condemnation)

Atlantic Monthly, March, 1881, vol. 47, p. 412.

Poems, Handy Volume Edition, 1881.

Boston Young Men's Christian Union

See "Hymn written for the Twenty-fifth Anniversary of the Reorganization," etc., and "Youth."

Boys, The (Written for the Class Meeting, Jan. 6, 1859)

Atlantic Monthly, Feb., 1859, vol. 3, pp. 240-241, in the "Professor."

Professor at the Breakfast-Table, 1859, pp. 61-62.

Songs and Poems of the Class of 1829, 1859, pp. 29-31.

Songs in Many Keys, 1862.

\section{Brave Old South, The}

"While stands the Coliseum, Rome shall stand;

When falls the Coliseum, Rome shall fall."

Leaflet, 1 page.

Poems of the Old South (illustrated), 1877, pp. 8-10.

Copies of the leaflet were sold at Libbie's in April, 1900, for $\$ 5.75$, and at Anderson's in the same month for $\$ 9.00$.

See "An Appeal for the Old South."

\section{Britain and America}

Canadian Journal of Agriculture, July, 1858, vol. 3, pp. 365-367. 
Addressed to Charles Mackay at Boston "on the eve of his final departure from American shores ... from the pen of the American poet Dr. Oliver Wendell Holmes."

See "A Good Time Going."

Broken Circle, The (Read at the Class Meeting, Jan. 6, 1887)

Atlantic Monthly, June, 1887, vol. 59, p. 842, in "Our Hundred Days in Europe."

Our Hundred Days in Europe, 1887, pp. 111-113.

Before the Curfew, and Other Poems, 1888.

Latest Poems of the Class of 1829, 1890, pp. 223-225.

Broomstick Train, The

Atlantic Monthly, Aug., 1890, vol. 66, pp. 246-248, in “Over the Teacups."

Over the Teacups, 1890, pp. 226-230.

Poems, Riverside Edition, 1891.

Brother Jonathan's Lament for Sister Caroline (March 25, 1861)

Atlantic Monthly, May, 1861, vol. 7, p. 613.

Chimes of Freedom and Union, 1861, pp. 27-28.

Songs in Many Keys, 1862.

Bryant's Seventieth Birthday (November 3, 1864)

The Bryant Festival at "The Century" (illustrated), 1865

(c. 1864), pp. $43-47 .^{1}$

Atlantic Monthly, Dec., 1864, vol. 14, pp. 738-740.

Songs of Many Seasons, 1875.

\section{But One Talent}

Atlantic Monthly, Dec., 1890, vol. 66, pp. 833-834.

Poems, Cambridge Edition, 1895.

Cacoethes Scribendi

Atlantic Monthly, March, 1890, vol. 65, p. 412, in "Over the Teacups."

Over the Teacups, 1890, p. 93.

Poems, Riverside Edition, 1891.

${ }^{1}$ Only 150 copies printed. 


\section{[ 14 ]}

Cambridge Churchyard, The

Poems, 1836, pp. 16-20.

Here printed as a part of "Poetry: a Metrical Essay," without separate title; in the contents, however, the above appears as a sub-title under "Poetry." First printed as a separate poem in Blue and Gold Edition, 1862.

\section{* Camilla}

The Poet among the Hills (J. E. A. Smith), 1895, pp. 153-154.

Written in 1855. A zealous parishioner of St. Stephen's, Pittsfield, called upon Dr. Holmes to ask him to contribute two poems for the "post-office" at a fair to be given by the parish. Having promised the poems, "Dr. Holmes, of course, escorted his fair besieger to the door; and in assisting her to remount her horse, being perhaps poetically nervous, he did not calculate with precise accuracy the amount of force necessary to place her gracefully in her seat. The saddle was, however, gained without a fall. But the poet, busy as he was, did not forget the incident, and when the fair postmistress received the two poems promised for her mail, there came also one for Miss M- which described it with his never-failing grace, wit, and accuracy." - Smith, pp. 151-153.

The gray robe trailing round her feet,

She smiled and took the slippered stirrup

(A smile as sparkling, rosy, sweet,

As soda, drawn with strawberry syrup); -

Now, gallant, now! be strong and calm, -

The graceful toilet is completed, -

Her foot is in thy hollowed palm -

One little spring, and she is seated!

No foot-print on the grass was seen,

The clover hardly bent beneath her,

I knew not if she pressed the green,

Or floated over it in ether;

Why, such an airy, fairy thing

Should carry ballast in her pocket, -

God bless me! If I help her spring

She'll shoot up heavenward like a rocket.

Ah, fatal doubt! The sleepless power

That chains the orbs of light together, 
Bends on its stem the slenderest flower

That lifts its plume from turf or heather;

Clasp, lady, clasp the bridle rein!

The filly stands - hold hard upon her!

Twine fast those fingers in her mane,

Or all is lost - excepting honor!

Earth stretched his arms to snatch his prize.

The fairies shouted "Stand from under!"

The violets shut their purple eyes,

The naked daisies stared in wonder;

One moment. - Seated in her pride,

Those arms shall try in vain to win her;

"Earth claims her not," the fairies cried,

"She has so little of it in her!"

* Cannibal, The

Collegian, April, 1830, no. 3, pp. 103-106.

Chambered Nautilus, The

Atlantic Monthly, Feb., 1858, vol. 1, pp. 468-469, in the "Autocrat."

Autocrat of the Breakfast-Table, 1858, pp. 110-111.

Songs in Many Keys, 1862.

Mr. Foley catalogues a privately printed edition of The Chambered Nautilus (12mo, Cambridge, 1879), with a translation into Latin, signed E. S. D. A copy of this edition was sold at Libbie's in April, 1897, for $\$ 13.00$. At the Edwin P. Whipple Sale, in April, 1903, the original ms. of the poem, with this inscription : "For Mr. Whipple, with kindest regards and good wishes, Christmas" [1879], was sold for $\$ 65.00$.

Chanson without Music. By the Professor Emeritus of Dead and Live Languages ( $\Phi$. B. K. Cambridge, 1867)

Atlantic Monthly, Nov., 1867, vol. 20, pp. 543-544.

Songs of Many Seasons, 1875.

Chinese Embassy, At the Banquet to the

See "At the Banquet," etc.

Choose You this Day whom Ye will Serve (Read at the Class Meeting, Jan. 8, 1863)

Atlantic Monthly, March, 1863, vol. 11, pp. 288-289. 


\section{[ 16 ]}

Songs and Poems of the Class of 1829, 1868, pp. 69-71.

Songs of Many Seasons, 1875.

See Appendix, p. 305, infra.

* City Madrigals (By the Author of State Prison Melodies)

The Amateur, April 9, 1831, no. 18, p. 275. Signed O. W. H.

Clarke, James Freeman

See "A Birthday Tribute," and "To James Freeman Clarke."

Class of '29. NTov. 6, 1856

Songs in Many Keys, 1862.

See "Our Indian Summer."

\section{Claudian Aqueduct, The}

The Token and Atlantic Souvenir, 1837 [c. 1836], pp. 337338.

In Table of Contents, "Roman Aqueduct, by O. W. Holmes." The poem is accompanied by a cut representing the ruins of an aqueduct, and there is a head-note, which, after describing the cut, continues: "The following lines handed us by a friend, though not accurately descriptive of this aqueduct, are full of beauty, and suggest many thoughts and feelings appropriate to the scene."

See "A Roman Aqueduct."

\section{Comet, The}

[Buckingham's] New England Magazine, April, 1832, vol. 2, pp. 300-301.

Poems, 1836.

The Boston Book, 1837, pp. 37-39.

\section{Coming Era, The}

Atlantic Monthly, Jan., 1880, vol. 45, pp. 84-85.

The Iron Gate, and Other Poems, 1880.

\section{Contentment}

Atlantic Monthly, Sept., 1858, vol. 2, pp. 502-503; in the "Autocrat."

Autocrat of the Breakfast-Table, 1858, pp. 312-315.

C[rocker], F[rederick] W[illiam]

See "Our Classmate, F. W. C." 
Crooked Footpath, The

Atlantic Monthly, April, 1859, vol. 3, p. 503, in the "Professor."

Professor at the Breakfast-Table, 1859, pp. 128-129.

Songs in Many Keys, 1862.

* Crossing the Ford

Youth's Keepsake; a Christmas and New Year's Gift for Young People, 1831, p. 198.

American Common-Place Book of Poetry, Geo. B. Cheever, editor, 1831, pp. 396-397.

Clouds, forests, hills and waters! - and they sleep

As if a spirit pressed their pulses down, -

From the calm bosom of the waveless deep

Up to the mountain with the sunlit crown,

Still as the moss-grown cities of the dead,

Save the dull plashing of the horse's tread.

And who are they that stir the slumbering stream?

Nay, curious reader, I can only say

That, to my eyes of ignorance, they seem

Like honest rustics on their homeward way;

There is a village; doubtless thence they came;

There was a christening; and they have a name.

They are to us, like many a living form,

The image of a moment, and they pass

Like the last cloud that vanished on the storm,

Like the last shape upon the faithless glass;

By lake, or stream, by valley, field, or hill,

They must have lived; perchance are living still.

\section{Daily Trials, by a Sensitive Man}

\section{Poems, 1836.}

Originally appeared in [Buckingham's] New England Magazine, vol. 3, p. 21, under the title "Ugly Reflections."

De Sauty. An Electro-Chemical Eclogue

Atlantic Monthly, Jan., 1859, vol. 3, p. 96, in the "Professor."

Professor at the Breakfast-Table, 1859, pp. 33-35.

Songs in Many Keys, 1862. 


\section{[ 18 ]}

Deacon's Masterpiece, The: or the Wonderful One-Hoss Shay

Atlantic Monthly, Sept., 1858, vol. 2, pp. 496-497, in the "Autocrat."

Autocrat of the Breakfast-Table, 1858, pp. 295-298.

Songs in Many Keys, 1862.

* "Dear little Dorothy, Dorothy Q"

Life and Letters of Oliver Wendell Holmes (Morse), 1896, vol. i, p. 231.

When Dr. Holmes heard of the birth of a daughter to his nephew and namesake, O. W. H. Upham, and that she was named Dorothy Q., "he wrote and sent to his little grandniece a couple of stanzas, which make a pretty pendant to the original poem [Dorothy Q.]." The ms. of the poem is still in the possession of the young lady to whom it was addressed. It was written in 1882 .

“Dear little Dorothy, Dorothy Q.,

What can I find to write to you?

You have two U's in your name, it's true, And mine is adorned with a double-u;

But there's this difference in the U's, That one you will stand a chance to lose When a happy man of the bearded sex Shall make it Dorothy Q. +X.

"May Heaven smile bright on the blissful day That teaches this lesson in Algebra!

When the orange blossoms crown your head, Then read what your old great-uncle said, And remember how in your baby-time He scribbled a scrap of idle rhyme, Idle, it may be - but kindly, too, For the little lady, Dorothy Q."

Departed Days

The Boston Book, 1841, p. 298.

Poems, London, 1846.

* Departure, The (The Athenæum Gallery)

The Amateur, June 15, 1830, no. 1, p. 16.

The Harbinger, 1833, pp. 32-34. 
* Destroyers, The

[Buckingham's] New England Magazine, March, 1832, vol. 2, p. 202.

Dialogue, A. Senex-Juvenis (Read at the Class Meeting, Jan. 9, 1879)

Additional Songs and Poems of the Class of 1829, 1881, pp.

-180-183.

Printed "with some changes" in the Atlantic Monthly for Aug., 1880, under the title "The Archbishop and Gil Blas."

Dickens, Charles, Dinner given to, by the Young Men of Boston

See "Song, written for the Dinner," etc.

Dilemma, The

[Buckingham's] New England Magazine, Jan., 1832, vol. 2, p. 36.

The Harbinger, 1833, pp. 46-48.

Poems, 1836.

Disappointed Statesman, The

Songs in Many Keys, 1862.

Poems, Household Edition, 1877.

See "The Statesman's Secret," "Readings over the Teacups," and "Each Heart has its own Secret."

* Dollar's Worth, A

The Poet among the Hills (J. E. A. Smith), 1895, pp. 156-157.

This was the second of the poems written by Dr. Holmes in 1855 for the "post-office" in connection with the St. Stephen's Church fair. (See "Camilla," and "Fair lady, whosoe'er thou art.") The motto on the envelope was:

"If man, or boy, or dolt, or scholar

Will break this seal, he pays his dollar;

But if he reads a single minute,

He'll find a dollar's worth within it"

* Domestic Thoughts

The Amateur, Sept. 4, 1830, no. 6, p. 92.

The Harbinger, 1833, pp. 40-41. 


\section{[20]}

Dorchester Giant, The

The Collegian, April, 1830, no. 3, pp. 123-125.

Poems, 1836.

Dorothy Q

Atlantic Monthly, Jan., 1871, vol. 27, pp. 120-121.

Songs of Many Seasons, 1875.

Dream, The (Written for the Class Meeting, Nov., 1854)

Songs and Poems of the Class of 1829, 1859, pp. 14-16.

See "The Old Man Dreams."

Dying Seneca, The

The Harbinger, 1833, pp. 31-32.

Poems, 1836.

Poems, Cambridge Edition, 1895.

Not in Household or Riverside Edition.

\section{* Each Heart has its own Secret}

In the Mercantile Library Reporter ("conducted by the Literary Committees of the Mercantile Library Association") for January, 1856, vol. $2,{ }^{1}$ pp. $36-40$, is a report of the opening of the fifteenth annual course of public lectures before the Association, on Wednesday [Thursday], Nov. 15, 1855, when an address was delivered by Prof. F. D. Huntington of Cambridge, and a poem by Dr. Holmes. After a sketch of Prof. Huntington's remarks the report continues (p. 38):-

"The new poem by Dr. Holmes, 'Each heart has its own Secret,' was the next grand feature of the evening. Although not written in the Doctor's most humorous vein, it nevertheless abounded in many sly hits and jocose allusions, and, when published (as it soon will be, with Mr. Huntington's address, under the auspices of the Association), we are confident that it will be eagerly sought for and read with intense pleasure, and will prove to be the happiest of the genial author's many happy efforts. . . .

"The unity of the poem consisted in the fact that all its parts illustrated the truth that 'Each Heart has its own Secret.' The illustrations were five in number, each of them a distinct, independent narrative or picture.

1 Only three volumes of this periodical were published. 


\section{[21]}

"The first may be called 'The Island Ruin.' Such a ruin as is described is still to be seen in Boston Harbor. The life of its former occupant was a mystety [sic]. His secret perished with him.

“'The second narrative, or picture, is 'The Banker's Dinner.' The supposed rich man gives a great banquet, which is described. His secret comes out at the end of the feast.

"The third story is that of a young Roman, who was sick, and nobody could tell what was the matter with him. A Greek physician came and found out his secret. This story is a variation on the old stories of Erasistratus and Galen.

"The fourth picture is that of a statesman who is unhappy in the midst of his triumphs. His secret, which all the world guesses, is a devouring ambition to reach a certain high office which really great men ought not to expect in these times.

"The fifth picture is that of Mary, the Virgin Mother, who kept the secret of her wonderful child in her own heart.

"The concluding lines relate to the secrets of the earth, of the stars, and of their Creator.

"In an introduction of about a hundred lines, a veteran actor is brought before the curtain, and his feelings and recollections traced in a few sketches.

"We subjoin some passages from different parts of the poem.

The compiler has been unable to discover any direct evidence that the address and poem were ever published "under the auspices of the Association;" inquiry at the rooms of the Association, which is still in existence, in its 86th year, failed to disclose any trace of such publication. But the following passages of a letter from J. L. Motley, to Dr. Holmes, dated May 3, 1857, prove conclusively that this same poem was sent - it may have been in print, or in manuscript, but as a single poem - to the historian; the last sentence, it will be noticed, identifies the place where it was delivered.

"I have read your poem a great many times, and have admired it more at each successive reading. Each of the episodes has freshness, strength and beauty, and the whole fabric is simple and noble... The episode of the young Roman is handled with much classic elegance, as well as with great tenderness and truth. The best portion, however, is that which embodies the mother's secret. ... The Webster photograph is bold, shadowy and imposing, but would probably elicit more 


\section{[22]}

hearty applause from a public audience than from some of us who have perhaps pondered too much the unheroic and the unpoetical elements which constituted so much of that goldenhearted and clay-footed image.

"The same remark I should be inclined to make upon the fraudulent banker. I suppose that you will not agree with me, and very likely it is some narrowness on my part, or oversqueamishness, but the particulars of a modern dinner-party will refuse to make poetry to my imagination. . . . The description of the ruined home on Apple Island is almost the best thing in the poem. . . .

"But you cannot do what I wish you to do except upon two conditions: one, devotion of your faculties and of your time to the one great object; the other, cotton-wooling your ears absolutely to all hand-clapping and greasy mob-applause of mercantile lecture-rooms." 1

When Dr. Holmes published the collection called "Songs in Many Keys," in 1862, he included therein, under the subheading, "Pictures from Occasional Poems, 1850-1856," certain portions of the Yale Phi Beta Kappa poem of 1850: "Astræa" (see supra,p. 7), and the following seven poems, viz., "The Old Player," "The Island Ruin," "The Banker's Dinner," “The Mysterious Illness," "A Mother's Secret," “The Disappointed Statesman," and "The Secret of the Stars." These poems were published under the same sub-heading, and with the same titles, in all subsequent collections prior to the Riverside Edition in $1895,{ }^{2}$ when all of them save the first were arranged in a new setting, with a prelude and interludes, and under different titles, with the exception of "The Secret of the Stars." "The Old Player" was left by itself among the Songs in Many Keys.

Now, it appears from the passages of "Each Heart has its own Secret" printed in the Mercantile Library Reporter that these

1 The morning papers of Thursday, Nov. 15, report this meeting of the Association, and the Advertiser gives an outline of the poem at some length. "The general theme was 'The Heart's Secret." - - The Post says: "The poem was a mystery. It abounded in the humor with which the Doctor is surcharged, revealing itself in flashes of jetty light .... all woven in a mystical braid, that like a strain of wild music, puzzled the mind to understand it, but made the heart feel better as it listened."

${ }^{2}$ And are still so printed in the Household Edition. 


\section{[23 ]}

seven poems were originally embodied in the long poem of that title read before the Mercantile Library Association. The "introduction of about a hundred lines" is "The Old Player," which has 120. "The Island Ruin" retains its name, as does "The Banker's Dinner;" "the story of the young Roman" (named Lucius) is "The Mysterious Illness;" "The Disappointed Statesman" retains its name, while the "picture of Mary, the Virgin Mother," becomes "A Mother's Secret." 1

The Riverside Edition of the Poems was prepared under the personal supervision of Dr. Holmes, so that the separation of "The Old Player" from its fellows was presumably intentional; but the editor of the Cambridge Edition was evidently not aware of the history of these poems, as he gives $1850-1856$ as the date of composition of those included in "Readings over the Teacups;" whereas it is clear enough that those dates, 1850-1856, meant that the extracts from "Astræa" belonged in 1850, and the others in 1856 (1855). Furthermore, in the Cambridge Edition 1859 is suggested as the probable date of "The Old Player."

Almost all of the passages given in the Reporter show some variations from the present text of the corresponding passages of the separate poems, and a number of lines are omitted altogether. For instance, at the close of the introduction, the subject of the poem is announced thus:

“The Heart's own Secret! How a single word

Would tell our history, and we die unheard!

When Love's dear witchery makes us more than kind;

When Friendship lifts the flood-gates of the mind;

When the red wine-cup brings its half-eclipse,

And the heart's night-birds flutter round the lips;

That single word the faithful traitors shun:

Tell follies, sins and secrets - all but oNE.

Behold the simple thread that intertwines

Its sober strand along my pictured lines."

And from the conclusion (The Secret of the Stars), these lines are quoted, referring to the national flag:

"One hue it borrows from the tropic rose, And one comes glistening from the polar snows;

${ }^{1}$ It had already appeared under that title in "The Professor at the Breakfast-Table," in the Atlantic Monthly for June, 1859. 


\section{[24]}

Forever braided, till the crownless Queen

Sweeps with its folds the mighty world between!"

Neither of these passages is to be found in any edition of Dr. Holmes's poems.

In rearranging the titles for resetting these poems, Dr. Holmes recurred to the original idea suggested in the title "Each Heart has its own Secret:" "The Island Ruin" becomes "The Exile's Secret;" "The Banker's Dinner," “The Banker's Secret;" "The Mysterious Illness," "The Lover's Secret;" and "The Disappointea Statesman," "The Statesman's Secret."

Enigma, An

The Collegian, Feb., 1830, no. 1, p. 43.

Epilogue to the Breakfast-Table Series. Autocrat - Professor - Poet. At a Bookstore, A. D. 1972

Atlantic Monthly, Dec., 1872, vol. 30, pp. 733-734, in the "Poet."

Poet at the Breakfast-Table, 1872, pp. 410-412.

Songs of Many Seasons, 1875.

Even-Song

Atlantic Monthly, March, 1870, vol. 25, pp. 349-351.

Songs of Many Seasons, 1875.

See "Ad Sodales."

Evening, by a Tailor

The Collegian, July, 1830, no. 6, pp. 255-256.

The Gleaner, 1830.

The Harbinger, 1833, pp. 56-58.

Poems, 1836.

Evening Thought, An. Lines written at Sea

Poems, 1836.

Originally appeared, under the title "Lines Written at Sea" (unsigned), in American Monthly Magazine, May, 1836, vol. 7, pp. 183-184.

Everett, Edward

See "Our First Citizen."

Exile's Secret, The

Poems, Riverside Edition, 1891.

Poems, Cambridge Edition, 1895. 
Originally printed, under the title "The Island Ruin," as one of the group Pictures from Occasional Poems, in Songs in Many Keys, 1862, and still so printed in the Household Edition. See "Each Heart has its own Secret."

\section{Extracts from a Medical Poem}

Poems, 1849.

These "extracts" are "The Stability of Science," "A Portrait," and "A Sentiment." The second, the subject of which was the universally beloved and respected Dr. James Jackson, was slightly changed in subsequent editions, the first line,

"Simple in youth, but not austere in age,"

becoming "Thoughtful in youth," etc.

* " Fair lady, whosoe'er thou art"

The Poet among the Hills (J. E. A. Smith), 1895, pp. 155156.

This is one of the two poems written by Dr. Holmes in 1855 for the "post-office" in connection with the entertainment given by St. Stephen's Parish, Pittsfield. (See "Camilla.") "The poem was inclosed in an envelope upon which was written this motto:

"Faith is the conquering Angel's crown;

Who hopes for grace must ask it;

Look shrewdly ere you lay me down,

I'm Portia's leaden casket."

Within the envelope was the poem:

“Fair lady, whosoe'er thou art,

Turn this poor leaf with tenderest care,

And - hush, $O$ hush thy beating heart -

The One thou lovest will be there!

"Alas! not loved by thee alone,

Thine idol, ever prone to range;

To-day, all thine, to-morrow flown,

Frail thing that every hour may change.

"Yet, when that truant course is done,

If thy lost wanderer reappear,

Press to thy heart thy only One

That nought can make more truly dear!" 


\section{[26 ]}

Within this sheet was a slip of paper, with the following verses, inclosing a one dollar bill:

"Fair lady, lift thine eyes and tell

If this is not a truthful letter;

This is the one (1) thou lovest well,

And nought (0) can make thee love it better (10).

"Though fickle, do not think it strange

That such a friend is worth possessing,

For one that gold can never change

Is Heaven's own dearest earthly blessing."

* Fairy World, The

Youth's Keepsake; a Christmas and New Year's Gift for

Young People, 1831, pp. 207-209.

\section{Familiar Letter to Several Correspondents, A}

Atlantic Monthly, Jan., 1876, vol. 37, p. 103.

Poems, Household Edition, 1877.

Family Record, A

The Independent, July 12, 1877.

Poems, Household Edition, 1877.

Fantasia

Atlantic Monthly, Feb., 1872, vol. 29, p. 236, in the "Poet."

Poet at the Breakfast-Table, 1872, pp. 71-72.

Songs of Many Seasons, 1875.

Farewell to Agassiz, A (Written on the Eve of Agassiz's journey to Brazil, in 1865)

Humorous Poems, 1865.

Songs of Many Seasons, 1875.

Farewell to J. R. Lowell, A

Poems, Household Edition, 1877.

See "A Good-by."

First Fan, The (Read at a Meeting of the Boston Bric-àBrac Club, February 21, 1877)

Atlantic Monthly, May, 1877, vol. 39, pp. 659-662.

Poems, Household Edition, 1877. 


\section{[27 ]}

First Verses (Phillips Academy, Andover, 1824 or 1825)

Poems, Household Edition, 1877.

Translation from the Eneid, Book I. "It is sixty-one years since I read my first verses at Phillips Academy." Dr. Holmes's speech at the first dinner of the P. A. Alumni Association, March 24, 1886.

\section{* Fish-Pieces, The}

The Amateur, June 15, 1830, no. 1, pp. 12-13. In "Annual Exhibition of Paintings."

Flaneur, The (Boston Common, Dec. 6, 1882, during the Transit of Venus)

Atlantic Monthly, May, 1883, vol. 51, pp. 674-677.

Poems, Riverside Edition, 1891.

* Flies, The (Poetry of Real Life)

The Amateur, Sept. 4, 1830, no. 6, p. 90.

Flower of Liberty, The

Atlantic Monthly, Nov., 1861, vol. 8, p. 550.

Songs in Many Keys, 1862.

For the Burns Centennial Celebration (Jan. 25, 1859)

Celebration of the Hundredth Anniversary of the Birth of Robert Burns by the Boston Burns Club, 1859, pp. 44-45.

Songs in Many Keys, 1862.

For the Centennial Dinner of the Proprietors of Boston Pier, or the Long Wharf (April 16, 1873)

Centennial of the Boston Pier, or the Long Wharf Corporation, 1873, pp. 18-20 (preceded by remarks by O. W. H.). Songs of Many Seasons, 1875.

For Class Meeting (Written for the Class Meeting, Jan. 7, 1875)

Poems, Household Edition, 1877.

Additional Songs and Poems of the Class of 1829, 1881, pp. 160-161.

Here printed with no other title than "Lines." 


\section{[28 ]}

For the Commemoration Services (Cambridge, July 21, 1865)

Songs of Many Seasons, 1875.

There seems to have been no separate publication of the exercises on this occasion except Mr. Lowell's Commemoration Ode. Harvard College preserves the record of the day in a copy of the New York Times for Tuesday, July 25, 1865.

\section{For the Dedication of the New City Library, Boston}

Proceedings on the Occasion of Laying the Corner-Stone of the New Library Building of the City of Boston, Nov. 28, 1888 (1889), pp. 17-20. (Page 17 is a half-title. The poem is on pp. 19-20.)

Poems, Riverside Edition, 1891.

For the Meeting of the Burns Club, 1856

Celebration of the Hundredth Anniversary of the Birth of Robert Burns, by the Boston Burns Club, 1859, pp. 19-21.

In "Record of Transactions" of the Burns Club, under date of Jan. 25, 1856 (97th anniversary). The poem as printed in Songs in Many Keys, and since, is thus introduced:

"The following witty introduction, and beautiful poem, were read by Dr. Oliver Wendell Holmes, one of the guests on the occasion, and always a cherished friend of the Club:

"I have come with the rest, I can hardly tell why, With a line I will read you before it is dry.

I know I've no business among you, full well, But I'm here, notwithstanding, and how, I will tell.

“ It was not a billet beginning 'Dear Sir;'

No missive like that would have coaxed me to stir; Nor a ticket, announcing the 'on' and the 'at,' And 'requesting the honor,' - ' $t$ was better than that.

“It was done by a visit, from one that you know, Whose smile is unchilled by life's season of snow, Whose voice is so winning, resist as you may, You must do what it says, for it will have its way.

"It is true that at first I began to suggest I should sit like a stranger apart from the rest; 
But he said: 'To no clan is our banquet confined, For the heart of the poet belongs to mankind.'

“ Then I timidly asked, 'Can I run, at a pinch, If our friends from the old world have learned how to lynch ?' For I thought with dismay of the Know-Nothing Crew, And I fancied a yell - 'He's a Know-Nothing too!'

"I thought of old Porteous, of Hare and of Burke; I remembered the witches of Alloway Kirk; 'Why bless you,' he said with a smile, 'if you're cotched, You will never be killed, you will only be Scotched!'

" So I came, and I'm here, with a line as I said;

I don't mean the verses that just have been read, But the ones in my pocket, and so, if you please, You shall hear them at once if you'll pardon me these."

Songs in Many Keys, 1862.

For the Meeting of the National Sanitary Association (1860)

Proceedings and Debates of the Fourth National Quarantine and Sanitary Convention, Boston, 1860, pp. 135-136. Remarks by O. W. H. on pp. 134-135.

Songs in Many Keys, 1862.

For the Moore Centennial Celebration (May 28, 1879)

The Iron Gate, and Other Poems, 1880.

For the Services in Memory of Abraham Lincoln

Memorial Services in Honor of Abraham Lincoln, at Music Hall, Boston, June 1, 1865; Order of Services, p. 3.

A Memorial of Abraham Lincoln, etc., 1865. Songs of Many Seasons, 1875.

For the Window in St. Margaret's (In Memory of a Son of Archdeacon Farrar)

Poems, Riverside Edition, 1891.

For Whittier's Seventieth Birthday (Dec. 17, 1877)

The Iron Gate, and Other Poems, 1880.

Forbes, John Murray

See "To J. M. F." 


\section{[ 30 ]}

Fountain of Youth, The (Read" at the Meeting of the

Harvard Alumni Association, June 25, 1873)

Atlantic Monthly, Aug., 1873, vol. 32, pp. 209-210.

Songs of Many Seasons, 1875.

Freedom, our Queen

Songs in Many Keys, 1862.

From a Bachelor's Private Journal

The Amate'r, July 3, 1830, no. 2, p. 22.

The Harbinger, 1833, pp. 39-40.

Poems, 1836.

Garfield, President, On the Death of

See "On the Death of President Garfield."

* Gipsy, The

The Amateur, June 15, 1830, no. 1, p. 13. In "Annual Exhibition of Paintings."

Girdle of Friendship, The (Read at the Class Meeting, Jan. 10, 1884)

Atlantic Monthly, March, 1884, vol. 53, pp. 386-387.

Before the Curfew, and Other Poems, 1888.

Latest Poems of the Class of 1829, 1890, pp. 213-214.

God Save the Flag

Atlantic Monthly, Jan., 1865, vol. 15, p. 115.

Songs of Many Seasons, 1875.

Golden Flower, The

Poems, Riverside Edition, 1891.

Good Time Going, A

Atlantic Monthly, July, 1858, vol. 2, pp. 244-245, in the "Autocrat."

Autocrat of the Breakfast-Table, 1858, pp. 259-261.

Songs in Many Keys, 1862.

Printed in the Canadian Journal of Agriculture, July, 1858, vol. 3, pp. 365-367, under the title "Britain and America," which see. 


\section{[ 31 ]}

Good-by, A. To J. R. Lowell (April 29, 1855)

Songs in Many Keys, 1862.

See "A Farewell to J. R. Lowell."

Gould, Dr. Benjamin Apthorp, A Welcome to

See "A Welcome to Dr. Benjamin Apthorp Gould."

* Graduate's Song, The

The Collegian, July, 1830, no. 6, p. 282.

Grandmother's Story of Bunker Hill Battle

Memorial, Bunker Hill, 1875, pp. 1-4 (pages unnumbered). ${ }^{1}$

Proceedings of Mass. Historical Society, May 13, 1875, vol. 14, pp. 33-36.

Poems, Household Edition, 1877.

A Memorial of the American Patriots who fell at the Battle of Bunker Hill, June 17, 1775. With an account of the Dedication of the Memorial Tablets on Winthrop Square, Charlestown, June 17, 1889, etc., pp. 245-250.

Gray Chief, The (1859)

Songs in Many Keys, 1862.

Grisette, La

American Monthly Magazine, April, 1836, n. s. vol. 1, p. 377.

Poems, 1836.

Hail, Columbia! (Additional Verses, written at the request of the Committee for the Constitutional Centennial Celebration at Philadelphia, 1887)

Poems, Riverside Edition, 1891.

Halleck [Fitz-Greene] Monument, Dedication of

See "Poem at the Dedication," etc.

$\because$ This is a quarto pamphlet of 16 unnumbered pages; ornamental cover and title-page combined: view of Bunker Hill on inside of front cover; poem, "The Crossed Swords," by N. L. Frothingham, on inside of back cover; cut of monument on back cover; pictorial borders to all the pages, and numerous portraits and cuts. Boston, James R. Osgood and Co. On page 1 is the following note: "As this poem is written expressly for this Memorial and not intended for publication elsewhere, the Publishers request that it be not copied or reprinted." 


\section{[32 ]}

Harvard (Read at the Commenčlement Dinner, 1880)

Poems, Cambridge Edition, 1895.

Harvard: Two Sonnets-Christo et Ecclesiæ: Veritas

Leaflet.

Proceedings of the Harvard Club of New York City at their 12th annual dinner, held at Delmonico's, Feb. 21, 1878, p. $16 .^{1}$

The Iron Gate, and Other Poems, 1880.

Harvard College, Alumni of

See "Meeting of the Alumni," etc., "The Old Cruiser," and "Vestigia Quinque Retrorsum."

Harvard College, Centennial Celebration of

See "A Song for the Centennial," etc.

Harvard College, Two Hundred and Fiftieth Anniversary of

See "Poem for the Two Hundred and Fiftieth Anniversary," etc.

* Hast thou a look for me, love?

[Buckingham's] New England Magazine, Oct., 1831, vol. 1, p. 319, in "A Week of Frailty."

Hayes, Rutherford Burchard

See "To R. B. H."

Hedge, Frederick Henry

See "To Frederick Henry Hedge."

Height of the Ridiculous, The

The Collegian, July, 1830, no. 6, pp. 285-286.

Poems, 1836.

\section{Home}

Exercises in celebrating the Two Hundred and Fiftieth Anniversary of the Settlement of Cambridge, Dec. 28, 1880 (1881), pp. 33-35.

See "Our Home - Our Country."

1 On pp. 16-17 of the same pamphlet is a letter of Dr. Holmes to Mr. John O. Sargent, which is printed also in Mr. Morse's Life and Letters of O. W.H., vol.i, pp. 236-238. 


\section{[33 ]}

Homesick in Heaven

Atlantic Monthly, January, 1872, vol. 29, pp. 103-104, in the " Poet."

Poet at the Breakfast-Table, 1872, pp. 37-40.

Songs of Many Seasons, 1875.

Hot Season, The

Poems, 1836.

* "How came I here?' The Portrait thus might speak"

Boston Medical and Surgical Journal, May 5, 1892, vol. 126, pp. 451-452.

See Appendix, pp. 306-309, infra.

How not to Settle It (Read to the Class, Jan. 4, 1877)

Atlantic Monthly, Feb., 1877, vol. 39, pp. 257-259.

Poems, Household Edition, 1877.

Additional Songs and Poems of the Class of 1829, 1881, pp. 168-173.

How the Old Horse won the Bet. Dedicated by a contributor to The Collegian, 1830, to the Editors of the Harvard Advocate, 1876.

Atlantic Monthly, July, 1876, vol. 38, pp. 44-48.

Poems, Household Edition, 1877.

New Verses from the Harvard Advocate, privately printed [1886], pp. xv-xxii. ${ }^{1}$

On page xxiii of the volume last cited is the following note: "'How the Old Horse Won the Bet,' was read at one of the Advocate dinners. Mr. Lowell and Harvard's poets, of the Advocate staff, were upon the course that day, to bestow the palm on 'The same that drew the One Hoss Shay.' . . . We all

${ }^{1}$ In the Harvard Advocate, May 26, 1876, vol. 16, p. 88, is an account of the decennial dinner, on May 11, by Charles $\mathrm{H}$. Barrows, in which we find the following reference to this poem:-

"Dr. Holmes, ... . to the surprise and gratification of all, finished his speech by producing a poem, prepared for the occasion, which he read in the happiest way, interrupted at various points by applause. The subject was 'The Old Horse,' a sequel to the 'Wonderful One-Hoss Shay,' the leading character being the horse instead of the 'shay.' The author's native humor was well-sustained throughout his verses, and one or two local hits were especially appreciated." 


\section{[34 ]}

thank the Doctor for this, and for much besides. The Doctor is the dear and ever-young colleague of all Harvard editors. With them, perennially,

'He steps a five-year-old again.'

Our founders, the Class of 1867 , have a closer bond with Dr. Holmes, in the common memory of one whom it will be always of good cheer to remember."

The last reference is to Dr. Holmes's younger son, Edward Jackson Holmes, of the Class of 1867, who died in 1884 .

In the Harvard Graduates' Magazine for June, 1906, vol. 14, p. 600, Mr. T. T. Baldwin says ("Forty Years of the Harvard Advocate "): "It is related that a few days after the dinner two of the editors waited upon the genial doctor and asked permission to print the verses in the Advocate, to which request he replied: 'Young gentlemen, that poem might do to read before your board, but I hardly think it worthy a place in your columns.' It appeared two months later in the Atlantic."

Howe, Dr. Samuel G.

See "A Memorial Tribute."

Hudson, The. After a Lecture at Albany (Dec., 1854)

Songs in Many Keys, 1862.

Humboldt's Birthday. Centennial Celebration, Sept. 14, 1869

Songs of Many Seasons, 1875.

Originally appeared, under the title "Bonaparte, August 15, 1769 - Humboldt, September 14, 1769," in Atlantic Monthly, Dec., 1869, vol. 24, pp. 637-638.

Hymn - After the Emancipation Proclamation

Songs of Many Seasons, 1875.

Hymn : The Word of Promise

See "The Word of Promise."

Hymn at the Funeral Services of Charles Sumner (April 29, 1874)

A Memorial of Charles Sumner, from the City of Boston, 1874, pp. 76-77.

Songs of Many Seasons, 1875. 


\section{[35 ]}

Hymn [for the Class Meeting] (Written for the Class, and sung at their meeting, Jan. 6,1869$)$

Broadside, 8vo, pp. 2. Poem on page 1, dated Jan. 6, 1869, and signed $\mathrm{O}$. W. H.

Songs of Many Seasons, 1875.

Additional Songs and Poems of the Class of 1829, 1881, p. 124.

Hymn for the Dedication of Memorial Hall at Cambridge (June 23, 1874)

Harvard Book, 1875, vol. ii, p. 54.

Songs of Many Seasons, 1875.

There is in the archives of Harvard College a manuscript record of the "Proceedings of the Committee of Fifty upon the subject of a Memorial Hall, appointed July 19th, 1865." It contains the order of exercises and the poems.

Hymn for the Fair at Chicago (1865)

Songs of Many Seasons, 1875.

Hymn for the Inauguration of the Statue of Governor Andrew

Poems, Household Edition, 1877.

A Memorial Volume containing the exercises at the dedication of the Statue of John A. Andrew at Hingham, Oct. 8, 1875 (1878), p. 73.

Hymn for the Laying of the Corner-Stone of Harvard Memorial Hall (Oct. 6, 1870)

Harvard College, services on the laying of the corner-stone, etc., 1870.

Harvard Book, 1875, vol. ii, p. 56 .

Songs of Many Seasons, 1875.

Hymn for the Two Hundredth Anniversary of King's Chapel

Programme of the Commemoration by King's Chapel, Boston, of the Completion of Two Hundred Years since its Foundation, on Wednesday, December 15, 1886.

The Commemoration, etc., 1887, p. 60.

Poems, Riverside Edition, 1891.

Hymn of Peace, A (Sung at the Jubilee, June 15, 1869, to the Music of Keller's American Hymn)

Grand National Peace Jubilee and Musical Festival. Official

Programme for the First Day, June 15, 1869, p. 4.

Songs of Many Seasons, 1875 . 


\section{[36 ]}

Hymn of Trust, A

Atlantic Monthly, Nov., 1859, vol. 4, pp. 633-634, in the "Professor."

Professor at the Breaiffast-Table, 1859, p. 356.

Songs in Many Keys, 1862.

Hymn read at the Dedication of the Oliver Wendell Holmes Hospital at Hudson, Wisconsin, 1887

Poems, Riverside Edition, 1891.

The compiler has been informed by Dr. I. D. Wiltrout, formerly of Hudson, the founder of the O. W. H. Hospital at that place, that he is the possessor of a considerable number of letters from Dr. Holmes (preceding and following the composition of this poem), none of which have been published. The Hospital has ceased to be called by its original name, and is now known as "The Sanatorium."

\section{Hymn written for the Great Central Fair at Philadelphia}

Our Daily Fare, ${ }^{1}$ Philadelphia, June 8, 1864, no. 1, p. 7.

Poems, Cambridge Edition, 1895.

Not in Riverside Edition.

Hymn written for the Twenty-Fifth Anniversary of the Reorganization of the Boston Young Men's Christian Union, May 31, 1893

Leaflet, 8vo.

Poems, Cambridge Edition, 1895.

Not in Riverside Edition.

* "I cannot say if truth there be"

[Buckingham's] New England Magazine, March, 1832, vol. 2, p. 227, in "The Debut."

I cannot say if truth there be

In that fantastic tale

About the bargain made between

The toad and nightingale; -

But thou - if thou hast ever called

One heavenly gift thine own-

1 A newspaper published daily during the Fair, June 8-21, 1864. 


\section{[ 37 ]}

Hast let it go, and kept unsold Thine ugliness alone.

$O$ would the blazing chandelier, That lights each hideous line, But save its rays for eyes that beam And cast its shade on thine!

$O$ would the laboring echoes cease Thine accents to repeat!

Thou wert in shadow doubly fair, In silence doubly sweet!

\section{Like You and I Love You}

Atlantic Monthly, May, 1890, vol. 65, p. 703, in "Over the Teacups."

Over the Teacups, 1890, pp. 144-145.

Poems, Riverside Edition, 1891.

* Idle Boys, The

The Amateur, June 15, 1830, no. 1, p. 13, in "Annual Exhibition of Paintings."

\section{Illustration of a Picture}

Poems, 1836.

Impromptu, An (Read at the Walcker Dinner on the completion of the Great Organ for Boston Music Hall, 1863)

Poems, Cambridge Edition, 1895.

Not in Riverside Edition.

Impromptu, An - Not Premeditated (Written for the Class Meeting, Nov. 29, 1853)

Songs of the Class of 1829, 1854, p. 10.

Poems, Household Edition, 1877.

* "In gentle bosoms tried and true"

Life of Henry Wadsworth Longfellow, by Samuel Longfellow, 1886, vol. iii, p. 85.

H. W. L.'s Journal, Feb. 27, 1867. Longfellow's sixtieth birthday. "At supper Holmes read these lines:

"In gentle bosoms tried and true

How oft the thought will be, 


\section{[ 38 ]}

'Dear friend, shall I remember you,

Or you remember me?'

"But thou, sweet singer of the West,

Whose song in every zone

Has soothed some aching grief to rest

And made some heart thine own,

"Whene'er thy tranquil sun descends, -

Far, far that evening be, -

Waat mortal tongue may count the friends

That shall remember thee?"

In Memoriam

See "The Old Man Dreams."

In Memory of J. D. R.

See “J[ames] D[utton] R[ussell]."

In Memory of Charles Wentworth Upham, Junior (1860)

Songs in Many Keys, 1862.

In Memory of J[ohn] W[are] R[obert] W[are] (Read at the Annual Meeting of the Massachusetts Medical Society, May 25, 1864)

Atlantic Monthly, July, 1864, vol. 14, pp. 115-116.

Boston Medical and Surgical Journal, July 7, 1864, vol. 70, p. 467.

Songs of Many Seasons, 1875.

In Memory of John Greenleaf Whittier (Dec. 17, 1807Sept. 7, 1892)

Atlantic Monthly, Nov., 1892, vol. 70, pp. 648-649.

Poems, Cambridge Edition, 1895.

Not in Riverside Edition.

In Response (Breakfast at the Century Club, New York, May, 1879)

The Iron Gate, and Other Poems, 1880.

In the Twilight

See "Before the Curfew." 


\section{[39 ]}

Inconnue, $\mathrm{L}^{\prime}$

"Is thy name Mary, maiden fair?"

[Buckingham's] New England Magazine, Oct., 1831, vol. 1, pp. 316-320, in "A Week of Frailty."

The Harbinger (1833), pp. 48-49.

Poems, 1836.

In last-mentioned volume first printed with the above title.

\section{* Infelix Senectus}

The Amateur, Sept. 4, 1830, no. 6, p. 95.

The Gleaner, 1830, pp. 161-162.

International Ode. Our Father's Land (Sung in unison by 1200 children of the public schools, at the visit of the Prince of Wales to Boston, Oct. 18, 1860)

The New England Tour of his Royal Highness the Prince of Wales, etc., 1860, p. 19.

Songs in Many Keys, 1862.

\section{Invita Minerva}

Atlantic Monthly, Nov., 1890, vol. 66, p. 671, in "Over the Teacups."

Over the Teacups, 1890, p. 314.

Poems, Riverside Edition, 1891.

* Invocation, An

The Collegian, May, 1830, no. 4, pp. 199-200.

Iris, her Book

Atlantic Monthly, Oct., 1859, vol. 4, p. 500, in the "Professor."

Professor at the Breakfast-Table, 1859, pp. 285-287.

Songs in Many Keys, 1862.

Iron Gate, The (Read at the Breakfast given in honor of

Dr. Holmes's Seventieth Birthday by the Publishers of the Atlantic Monthly, Dec. 3, 1879)

Atlantic Monthly, Feb., 1880, vol. 45, supp. pp. 4-5.

The Iron Gate, and Other Poems, 1880.

A ms. copy of the poem, in Dr. Holmes's hand and initialed by him, brought $\$ 50.00$ at the Williamson Sale in March, 1904. 


\section{[ 40 ]}

Island Hunting-Song, The

Poems, 1849, 2d issue.

Printed under the title "Song," in Verses from the Island Book, 1865.

"The island referred to is a domain of princely proportions, which has long been the seat of a generous hospitality. Naushon is its old Indian name. William Swain, Esq., commonly known as 'the Governor,' was the proprictor of it at the time when this song was written." - Note of Dr. Holmes in Riverside Edition.

Island Ruin, The

Songs in Many Keys, 1862.

Poems, Household Edition, 1877.

See "The Exile's Secret," "Each Heart has its own Secret," and "Readings over the Teacups."

Japanese Embassy, At the Banquet to the

See "At the Banquet," etc.

* Jubilee, The

The Boatswain's Whistle (published at the National Sailors'

Fair), Nov. 15, 1864, no. 5, p. 37.

Humorous Poems, 1865.

King's Chapel (Read at the Two Hundredth Anniversary)

Atlantic Monthly, Sept., 1883, vol. 52, pp. 322-323.

The Commemoration, etc., 1887, pp. 131-133.

This is the first publication of this poem in a book, although it was not written for the anniversary.

Poems, Riverside Edition, 1891.

* Lady Drinking (The Athenæum Gallery)

The Amateur, June 15, 1830, no. 1, p. 16.

Last Blossom, The

Atlantic Monthly, May, 1858, vol. 1, p. 877, in the "Autocrat." Autocrat of the Breakfast-Table, 1858, pp. 186-187.

Songs in Many Keys, 1862.

Last Charge, The (Read at Class Meeting, Jan. 7, 1864)

Atlantic Monthly, Feb., 1864, vol. 13, p. 244.

Songs and Poems of the Class of 1829, 1868, pp. 77-78.

Songs of Many Seasons, 1875. 


\section{[41]}

A signed copy of this poem, in Dr. Holmes's hand, dated Jan. 7, 1864, brought $\$ 16.00$ at auction, in May, 1895 .

\section{Last Leaf, The}

The Amateur, March 26, 1831, no. 17, p. 261. Signed

O. W. H.

The Harbinger, 1833, pp. 34-36.

The Laurel, 1836.

Knickerbocker, or New York Monthly Magazine, Feb., 1836, vol. 7, p. 219.

In a review of The Laurel, where "The Last Leaf" is described as an "oddly-pathetic poem, by O. W. Holmes Esq., a fine prose-writer, and no mean poet."

Poems, 1836.

Last Look, The. W. W. Swain

Atlantic Monthly, Nov., 1858, vol. 2, p. 749.

Songs in Many Keys, 1862.

Verses from the Island Book, 1865.

Written at Naushon in September, 1858. W. W. Swain was the son of the "Governor" Swain to whom an earlier poem was addressed. See "To Grovernor Swain."

* Last Prophecy of Cassandra, The

The Collegian, March, 1830, no. 2, pp. 55-56.

Poems, 1836.

Poems, Cambridge Edition, 1895.

Not in Household or Riverside Edition.

Last Reader, The

American Monthly Magazine, April, 1836, n. s. vol. 1, pp. 372-373.

Poems, 1836.

In the magazine "corroding" was substituted for "sarcastic" in the third line of the third stanza:

"Or o'er them his sarcastic thread;"

"changed by the New York editor on his own responsibility," says Dr. Holmes, " "which occasioned immense indignation on my part, and a refusal to write until he would promise to keep hands off."

${ }^{1}$ In a letter to J. F. Clarke, of May 11, 1836, printed by Mr. Morse in his Life and Letters of Dr. Holmes, vol. ii, p. 270. 


\section{[42]}

Last Survivor, The (Read at Class Meeting, Jan. 10, 1878)

The Iron Gate, and Other Poems, 1880.

Additional Songs and Poems of the Class of 1829, 1881, pp. 176-180.

\section{Latter-Day Warnings}

Atlantic Monthly, Nov., 1857, vol. 1, p. 57, in the "Autocrat."

Autocrat of the Breakfast-Table, 1858, pp. 26-27.

Songs in Many Keys, 1862.

\section{Lexington}

Poems, 1849, 2d issue.

Lincoln, Abraham

See "For the Services in Memory of Abraham Lincoln."

Lines (Written for the Class Meeting, 1860) ${ }^{1}$

Songs and Poems of the Class of 1829, 1868, pp. 41-42.

Poems, Household Edition, 1877.

Lines by a Clerk

Poems, 1836.

First appeared in the Amateur (see below), under the title, "Lines by a Very Interesting Young Man."

\section{Lines by a Very Interesting Young Man}

The Amateur, April 9, 1831, no. 18, p. 273, signed O.W. H.

The Harbinger, 1833, pp. 42-43.

\section{Lines recited at the Berkshire Festival}

The Berkshire Jubilee, celebrated at Pittsfield, Mass., August

22 and 23, 1864, pp. 162-163.

Dr. Holmes's copy of this volume was sold by Bangs in June, 1899 , for $\$ 4.50$.

Poems, London, 1846.

Lines recited at the Cambridge Phi Beta Kappa Dinner [1844]

Poems, London, 1846.

${ }^{1}$ At this meeting of the Class, seven original poems were read by different members. 


\section{[43 ]}

See "Verses for After-Dinner."

Dr. John Pierce wrote in his diary, concerning this meeting of the Phi Beta Kappa: "One of the most humorous of the jeus [sic] d'esprit was from the pen of Dr. O. W. Holmes." (Proceedings of the Mass. Hist. Soc., 2d series, vol. 9, p. 137.)

Lines written at Sea

See Appendix, p. 309, infra.

Living Temple, The

Atlantic Monthly, May, 1858, vol. 1, pp. 882-883, in the "Autocrat."

Autocrat of the Breakfast-Table, 1858, pp. 202-203.

Songs in Many Keys, 1862.

Longfellow, Henry Wadsworth

See "In gentle bosoms, tried and true," “Our Dead Singer," and "To H. W. Longfellow."

\section{* Lost Boy, The}

The Token, 1831, pp. 27-28.

How sweet to boyhood's glowing pulse

The sleep that languid summer yields,

In the still bosom of the wild,

Or in the flowery fields!

So art thou slumbering, lonely boy -

But ah! how little deemest thou

The hungry felon of the wood

Is glaring on thee now!

He crept along the tangled glen,

He panted up the rocky steep,

He stands and howls above thy head, And thou art still asleep!

No trouble mars thy peaceful dream;

And though the arrow, winged with death,

Goes glancing near thy thoughtless heart,

Thou heedest not its breath.

Sleep on! the danger all is past,

The watch-dog, roused, defends thy breast,

And well the savage prowler knows

He may not break thy rest! 


\section{$[44]$}

Lover's Secret, The

Poems, Riverside Edition, 1891, in "Readings over the Teacups."

Poems, Cambridge Edition, 1895.

Originally printed under the title "The Mysterious Illness," as one of the group, Pictures from Occasional Poems, in Songs in Many Keys, 1862, and still so printed in the Household Edition. See "Each Heart has its own Secret."

Loving-Cup Scng, A (Read at the Class Meeting, Jan. 4, 1883)

Atlantic Monthly, March, 1883, vol. 51, pp. 349-350.

Before the Curfew, and Other Poems, 1888.

Latest Poems of the Class of 1829, 1890, pp. 211-212.

Lowell, James Russell, 1819-1891

Leaflet, 8vo.

Atlantic Monthly, Oct., 1891, vol. 68, pp. 552-553.

Poems, Riverside Edition, 1891. ${ }^{1}$

A copy of the leaflet, with Dr. Holmes's autograph, brought $\$ 8.00$ at the William Harris Arnold Sale in 1901 .

“ Lucy." For her Golden Wedding, Oct. 18, 1875

Poems, Household Edition, 1877.

Lyre of Anacreon, The (Read at the Class Meeting, Jan. 8, 1885)

Before the Curfew, and Other Poems, 1888.

Latest Poems of the Class of 1829, 1890, pp. 217-219.

Originally appeared, under the title "The Old Song," in the Atlantic Monthly, April, 1885, vol. 55, pp. 533-534, in "The New Portfolio" ["A Mortal Antipathy"].

\section{Maison d'Or, La (Bar Harbor)}

Atlantic Monthly, May, 1890, vol. 65, p. 703, in "Over the Teacups."

Over the Teacups, 1890, p. 172.

Poems, Riverside Edition, 1891.

${ }^{1}$ For other poems concerning Mr. Lowell, or addressed to him, see "At a Birthday Festival," "A Farewell to J. R. Lowell," "To J. R. Lowell," “To J. R. L.," "To James Russell Lowell." 


\section{[45]}

Mare Rubrum (Written for the Annual Meeting of the Class [Jan. 14], 1858)

Atlantic Monthly, March, 1858, vol. 1, pp. 624-625, in the "Autocrat."

Autocrat of the Breakfast-Table, 1858, pp. 140-142.

Songs and Poems of the Class of 1829, 1859, pp. 22-24.

Songs in Many Keys, 1862.

The poem as copied in the records of the Class bears no title. The following changes were made in the text before it was printed in the Atlantic. In stanza 6, line 5, wondrous was changed to maddening; ${ }^{1}$ and in stanza 7 , line 5 , tasteless to palest.

Martha. Died Jan. 7, 1861

Songs in Many Keys, 1862.

Massachusetts Medical Society, Centennial Dinner of the See "Poem for the Centennial Dinner," etc.

Meeting of the Alumni of Harvard College, 1857

Songs in Many Keys, 1862.

Meeting of the Dryads, The

The Collegian, June, 1830, no. 5, pp. 221-223.

Poems, 1836.

Written after a general pruning of the trees around Harvard College.

\section{Memorial Hall, Cambridge}

See "Hymn for the Laying of the Corner-Stone" and "Hymn for the Dedication of Memorial Hall."

Memorial Tribute, A (Read at the meeting, Feb. 8, 1876, in memory of Dr. Samuel G. Howe)

The Massachusetts Philanthropist. Memoir of Dr. Samuel Gridley Howe, etc., 1876, pp. 89-91.

Atlantic Monthly, April, 1876, vol. 37, pp. 464-466.

Poems, Household Edition, 1877.

1 Wondrous was afterward restored and is now the usual reading, except in the "Autocrat." 


\section{[ 46 ]}

$\mathbf{M}[$ eriam], H[oratio] C[ook], H[oward] S[argent], J[osiah] K[endall] W[aite] (Written for the Class Meeting, Jan. 9, 1873)

Songs of Many Seasons, 1875.

Additional Songs and Poems of the Class of 1829, 1881, pp. 153-155.

In last-mentioned volume printed with no other title than "Lines."

\section{Midsummer}

Atlantic Monthly, Sept., 1859, vol. 4, pp. 378-379, in the "Professor."

Professor at the Breakfast-Table, 1859, pp. 284-285.

Songs in Many Keys, 1862.

Mind's Diet, The

Songs in Many Keys, 1862.

See note to "Spring."

Modest Request, A. Complied with after the dinner at President Everett's Inauguration [1846]

Poems, 1849.

Dr. Holmes's " humorous poem" at this dinner is mentioned but not printed in Addresses at the Inauguration of the Hon. Edward Everett, LL.D., as President of the University at Cambridge,Thursday, April 30, 1846, Appendix, p. 61. The records of the Class of '29 contain a newspaper print of the poem, cut from the Boston Daily Advertiser.

\section{* Moonshine}

The Collegian, July, 1830, no. 6, p. 277.

The Harbinger (1833), pp. 59-60.

\section{Moral Bully, The}

Songs in Many Keys, 1862.

See note to "Spring."

Morning Visit, The ${ }^{1}$

The Boston Book, 1850, pp. 89-92.

Poems, Riverside Edition, 1891.

${ }^{1}$ See Memoir of Dr. James Jackson, by James Jackson Putnam, 1905, pp. 164-166. 


\section{Mother's Secret, A}

Atlantic Monthly, June, 1859, vol. 3, pp. 619-620, in the

"Professor."

Professor at the Breakfast-Table, pp. 159-163.

Songs in Many Keys, 1862.

Poems, Household Edition, 1877.

Mother's Secret, The

Poems, Riverside Edition, 1891.

Poems, Cambridge Edition, 1895.

Originally printed, under the title "A Mother's Secret," as above, and still so printed in the Household Edition. See "Each Heart has its own Secret."

Motley, J. L., A Parting Health to

See "A Parting Health to J. L. Motley."

\section{Musa}

Atlantic Monthly, Aug., 1858, vol. 2, pp. 369-370, in the "Autocrat."

Autocrat of the Breakfast-Table, 1858, pp. 290-292.

Songs in Many Keys, 1862.

Music-Grinders, The

Poems, 1836.

Printed under the title "Banditti" in the New England Galaxy, 1830, and in the Gleaner of the same date. The editor of the Cambridge Edition gives 1836 as the conjectural date of composition. The second line of stanza 4 originally read "Some filthy creature begs;" in the Household Edition, filthy was changed to odious.

My Annual. For the "Boys of '29" (At Annual Meeting, Jan. 4, 1866)

Atlantic Monthly, April, 1866, vol. 17, pp. 395-396.

Songs and Poems of the Class of 1829, 1868, pp. 84-86.

Songs of Many Seasons, 1875.

My Aunt

[Buckingham's] New England Magazine, Oct., 1831, vol. 1, p. 433.

The Harbinger, 1833, pp. 44-46.

Poems, 1836. 


\section{[48 ]}

My Aviary

Atlantic Monthly, Jan., 1878, vol. 41, pp. 122-125.

The Iron Gate, and Other Poems, 1880.

Mysterious Illness, The

Songs in Many Keys, 1862.

Poems, Household Edition, 1877.

See "The Lover's Secret," "Each Heart has its own Secret," and "Readings over the Teacups."

Mysterious Visitor, The

The Collegian, June, 1830, no. 5, pp. 212-214.

Poems, 1836.

In the last-named volume the last word of the title is spelled visiter.

Nearing the Snow-Line

Atlantic Monthly, Jan., 1870, vol. 25, p. 86.

Songs of Many Seasons, 1875.

Never or Now! An Appeal

Lyrics of Loyalty, 1864, pp. 241-242.

Songs of Many Seasons, 1875.

New Eden, The (Read before the Berkshire Horticultural Society at Stockbridge, Sept. 13, 1854)

Songs in Many Keys, 1862.

The Poet among the Hills (J. E. A. Smith), 1895, pp. 146-150.

New England Society in New York, the, Semi-Centennial Celebration of

See "Semi-Centennial Celebration," etc.

New York Mercantile Library Association, Annual Dinner of

See "Song, written for the Annual Dinner," etc.

No Time like the Old Time

Atlantic Monthly, Sept., 1865, vol. 16, pp. 398-399.

Poems, Riverside Edition, 1891.

Non-Resistance

Songs in Many Keys, 1862.

See note to "Spring." 
Noontide Lyric, A

Poems, 1836.

Originally appeared, under the title "Poultry," in the Amateur, July 3, 1830, no. 2, p. 25.

\section{Nux Postcœnatica}

Poems, 1849.

\section{* Octosyllabics}

The Collegian, July, 1830, no. 6, pp. 261-263.

Ode for a Social Meeting [with Slight Alterations by a Teetotaler]

Atlantic Monthly, Dec., 1857, vol. 1,p. 184, in the "Autocrat." Autocrat of the Breakfast-Table, 1858, p. 53.

Songs in Many Keys, 1862.

In last-named volume first printed with title.

Ode for Washington's Birthday (Mercantile Library Association, Feb. 22, 1856)

Songs in Many Keys, 1862.

\section{Old Cambridge}

Proceedings, July 3, 1875, in celebration of the Centennial Anniversary of Washington's taking Command of the Continental Army on Cambridge Common, 1875, pp. 88-91. ${ }^{1}$ Atlantic Monthly, Aug., 1875, vol. 36, pp. 237-239.

Laurel Leaves, 1876 [c. 1875], pp. 167-175.

Poems, Household Edition, 1877.

Old Cruiser, The (Written for the Class Meeting, Jan. 6, 1869)

Songs of Many Seasons, 1875.

1 This poem was read at the dinner in Memorial Hall, following the formal exercises, at which Mr. Lowell read his "Under the Old Elm." When Mr. Lowell was called upon to respond to the toast, "The Poet of the Day," he introduced Dr. Holmes, to "respond to the spirit of the toast." Dr. H. prefaced the reading of the poem with the following remarks:

"Ladies and Gentlemen, - I know you will not accuse me of lightly or wantonly taking the compliment to myself, when you have sat to-day and listened to my friend's inspiring poem; and I should hesitate to read the few verses $I$ have here, were it not that one was before and the other after dinner. I have addressed the gray heads and bald heads of this assembly more particularly, asking if they can tell where some of the old familiar places in this immediate vicinity are." 
Additional Songs and Poems of the Class of 1829, 1881, pp. 125-128.

The last four stanzas "were added and the completed lines read at the dinner of the Alumni, Commencement Day, June 29, 1869."

In the class publication, the title is "Lines," simply.

* Old Gentleman's Story, The

The Collegian, July, 1830, no. 6, pp. 277-279.

\section{Old Ironsides}

Boston Daily Advertiser, Sept. 16, 1830.

"One genuine lyric outburst, done in this year of the law, almost made him in a way actually famous. The frigate Constitution, historic indeed, but old and unseaworthy, then lying in the navy yard at Charlestown, was condemned by the Nary Department to be destroyed. Holmes read this in a newspaper paragraph, and it stirred him. On a scrap of paper, with a lead pencil, he rapidly shaped the impetuous stanzas of 'Old Ironsides,' and sent them to the Daily Advertiser, of Boston. Fast and far they travelled through the newspaper press of the country; they were even printed in hand-bills and circulated about the streets of Washington. An occurrence, which otherwise would probably have passed unnoticed, now stirred a national indignation. The astonished Secretary made haste to retrace a step which he had taken quite innocently in the way of business. The Constitution's tattered ensign was not torn down. The ringing spirited verses gave the gallant ship a reprieve, which satisfied sentimentality, and a large part of the people of the United States had heard of O. W. Holmes, law student at Cambridge, who had only come of age a month ago." - Life and Letters of O. W. Holmes, by J. T. Morse, Jr., vol. i, pp. 79-80. ${ }^{1}$

Poems, 1836, pp. 24-25.

Here printed as a part of "Poetry: a Metrical Essay," without

1 Curiously enough, while this compilation was in the making, a similar suggestion by the Secretary of the Navy (1905), with reference to the same venerable and venerated vessel, inspired a like outburst of popular feeling; the matter was made the subject of discussion in Congress, and Dr. Holmes's lines were recited dramatically on the floor of the House of Representatives by Mr. Sulzer of New York. See Congressional Record, Fifty-Ninth Congress, 1st Session, p. 578. See also the remarks of Mr. McCall of Massachusetts, ibid. p. 1226. 


\section{[51 ]}

separate title; in the Contents, however, the above title appears as a sub-title under "Poetry," which see.

The Boston Book, 1837, p. 239.

The poem was first printed separately, under its present title, in the Blue and Gold Edition of the Poems, in 1862.

A copy of "Old Ironsides," in Dr. Holmes's autograph, signed by him, and dated 1842, was sold by Bangs in Nov., 1900 , for $\$ 45.00$; another, 1 page, 4to, signed, with portrait, for $\$ 37.00$, in the Kennard Sale, April, 1904; and an autograph letter, including a copy of the poem, for $\$ 29.00$, in the Carson Sale, 1904.

\section{Old Man Dreams, The}

Atlantic Monthly, Jan., 1858, vol. 1, pp. 319-320, in the "Autocrat."

Autocrat of the Breakfast-Table, 1858, pp. 76-77.

Songs and Poems of the Class of 1829, 1859, pp. 14-16.

Songs in Many Keys, 1862.

This poem was written for and read at the annual meeting of the Class of 1829, on Nov. 23, 1854. The secretary of the Class, upon spreading it on his records, entitled it "In Memoriam;" but in the Songs of the Class of '29, it is called "The Dream." There are several variations between the manuscript copy in the Class records and the poem as printed:

Stanza 2, line 4, ms., has glories for trophies; stanza 4, line 2, smiling calmly for calmly smiling; stanza 6 reads in the ms.:

"Nay - since you call it to my mind,

One thing in manhood's life

I should not care to leave behind,

I think I'll take - my wife."

Stanza 7, line 3, ms., has youth for boy; stanza 8, line 1, ms., has still for yet; line 3, ms., has thy past has, for these gifts have; last stanza reads in the ms.:

"And so I laughed, and, laughing, woke

From dreams of fancied joys;

And came to tell the Angel's joke

Among us gray-haired boys."

Old Man of the Sea, The. A Nightmare Dream by Daylight Atlantic Monthly, Nov., 1858, vol. 2, pp. 743-744, in "A Visit to the Autocrat's Landlady." 


\section{[52 ]}

Songs in Many Keys, 1862.

The original ms. of the "Visit," including the poem, $22 \mathrm{pp}$. 4to, brought $\$ 195.00$ at the Williamson Sale, in March, 1904; at the same sale, 2 leaves, containing the first draft of the poem, beginning with the $2 \mathrm{~d}$ stanza, signed, brought $\$ 41.50$.

\section{Old Player, The}

Songs in Many Keys, 1862.

See "Each Heart has its own Secret."

\section{Old Song, The}

Atlantic Monthly, April, 1885, vol. 55, pp. 533-534, in "The New Portfolio."

A Mortal Antipathy; First Opening of the New Portfolio, 1885, pp. 85-86.

Read to the Class of 1829 , Jan. 8,1885 , and printed in Before the Curfew, and Other Poems, 1888, and all subsequent collected editions, under the title, "The Lyre of Anacreon."

Old Tune, The. Thirty-Sixth Variation (Read at the Class Meeting, Jan. 7, 1886.)

Atlantic Monthly, March, 1886, vol. 57, p. 373, in "Two 'Occasional' Poems with an Introduction" (The New Portfolio).

Before the Curfew, and Other Poems, 1888.

Latest Poems of the Class of 1829, 1890, pp. 219-220.

\section{Old-Year Song, An}

Atlantic Monthly, Jan., 1874, vol. 33, pp. 101-102.

Songs of Many Seasons, 1875.

Oliver Wendell Holmes Hospital at Hudson, Wisconsin, Hymn read at the Dedication of

See "Hymn read at the Dedication of," etc.

\section{On Lending a Punch-Bowl}

Poems, 1849.

\section{On the Death of President Garfield}

Poems, Riverside Edition, 1891.

Originally appeared under the title "After the Burial," in the Boston Globe, Garfield Memorial Number, Sept. 17, 1881. 


\section{[53 ]}

\section{On the Threshold}

The Iron Gate, and Other Poems, 1880.

Once More. Condiscipulis, Coœtaneis, Harvardianis, Amicis (Written for the Class Meeting, Jan., 1868)

Atlantic Monthly, March, 1868, vol. 21, pp. 430-431.

Songs and Poems of the Class of 1829, 1868, pp. 96-99.

Songs of Many Seasons, 1875.

\section{One Country (1865)}

Songs of Many Seasons, 1875.

One-Hoss Shay, The

See "The Deacon's Masterpiece."

\section{Only Daughter, The}

The Token and Atlantic Souvenir, 1838, pp. 33-36.

The Token, or Affection's Gift, 1846, pp. 33-36.

Poems, London, 1846.

This poem was omitted - accidentally, it would seem from the first issue of the Poems of $\mathbf{1 8 4 9}$ (that which bears the imprint of W. D. Ticknor and Co.), but was printed in the second issue (Ticknor, Reed and Fields). See the description of that edition of the poems, p. 128, infra.

Opening of the Piano, The

Atlantic Monthly, March, 1859, vol. 3, pp. 360-361, in the "Professor."

Professor at the Breakfast-Table, 1859, pp. 92-93.

Songs in Many Keys, 1862.

Opening the Window

Songs of Many Seasons, 1875, pp. iii-iv.

Organ-Blower, The

Old and New, Jan., 1872, vol. 5, pp. 69-70.

Songs of Many Seasons, 1875.

Our Banker (Written for the Class, Jan. 8, 1874)

Songs of Many Seasons, 1875.

Additional Songs and Poems of the Class of 1829, 1881, pp. 156-158.

In last-mentioned volume printed with no other title than "Lines." 


\section{[54 ]}

Our Classmate, F[rederick] W[illiam] C[rocker] (Written for the Class Meeting, Jan. 7, 1864)

Atlantic Monthly, March, 1864, vol. 13, pp. 329-330.

Songs and Poems of the Class of 1829, 1868, pp. 73-75.

Songs of Many Seasons, 1875.

Our Dead Singer. H. W. L.

Atlantic Monthly, June, 1882, vol. 49, pp. 721-722.

Before the Curfew, and Other Poems, 1888.

Our First Citizen [Edward Everett] (Read at the Meeting of the Massachusetts Historical Society, Jan. 30, 1865) Proceedings of the Mass. Hist. Soc. Jan. 30, 1865, vol. 8, p. 151.

Tribute of the Mass. Hist. Soc. to the Memory of Edward Everett, 1865, pp. 65-67.

Atlantic Monthly, April, 1865, vol. 15, pp. 462-463.

Memorial of Edward Everett, from the City of Boston, 1865, pp. 189-191.

Songs of Many Seasons, 1875.

\section{Our Home - Our Country}

Poems, Handy Volume Edition, 1881.

Printed under the title "Home," in Exercises in Celebrating the Two Hundred and Fiftieth Anniversary of the Settlement of Cambridge, 1880.

Our Indian Summer (Written for the Class Meeting, Nov., 1856)

Songs and Poems of the Class of 1829, 1859, pp. 20-21.

The title here is "A Poem," simply. Printed in Songs in Many Keys, 1862, under the title "Class of '29 (Nov. 6, 1856)." "Our Indian Summer" was first used as title in Poems, Household Edition, 1877.

According to the Class records Dr. Holmes read at this same meeting of 1856 "a portion of an epic" on the Class, of which no trace remains.

\section{Our Limitations}

Songs in Many Keys, 1862.

See note to "Spring." 


\section{[55 ]}

Our Oldest Friend (Read to "The Boys of '29," Jan. 5, 1865)

Atlantic Monthly, March, 1865, vol. 15, pp. 340-341.

Songs and Poems of the Class of 1829, 1868, pp. 80-82.

Songs of Many Seasons, 1875.

Our Sweet Singer. J[oseph] A[ngier] (Written for the Class Meeting, Jan. 4, 1872)

Atlantic Monthly, April, 1872, vol. 29, p. 496, in the "Poet." Poet at the Breakfast-Table, 1872, pp. 134-135.

Songs of Many Seasons, 1875.

Additional Songs and Poems of the Class of 1829, 1881, pp. 142-144.

In this latter compilation the poem is printed as in the copy spread on the Class records. But as printed in the "Poet," and in the collected editions, it shows the following variations from its original form: the $3 \mathrm{~d}$ and 9 th stanzas are omitted, and that which stands 6th in the revised form - "The cheering smile, the voice of mirth," etc. - does not appear in the ms. In the 5 th stanza the ms. has second childhood's instead of love and friendship's.

The 3d stanza in the ms. reads:

"Clear as the lark at morning's blush It filled the springtide bowers;

Sweet as the vesper-trilling thrush It charmed the autumn hours."

And the 9th:

"And if, in some great anthem's pause,

That voice should once begin -

May Heaven forgive its slighted laws!

The Boys would all strike in!"

\section{Our Yankee Girls}

American Monthly Magazine, March, 1836, n. s. vol. 1, p. 292.

Poems, 1836.

Boston Book, 1837, pp. 117-118.

"Our Yankee Girls" was set to music; a copy in sheet music form, published in 1852, was sold at the Pyser Sale, 1906, for $\$ 3.10$; and a copy in the same form, under the title "God Bless our Yankee Girls," with music by T. Comer (1854), brought $\$ 8.00$ at Bangs's in April, 1900. 
Papyrus Club, At the

See "At the Papyrus Club."

Parkman, Francis. Sept. 16, 1823-Nov. 3, 1893

Proceedings of the Massachusetts Historical Society, Nov. 21, 1893, 2d series, vol. 8, pp. 360-361.

Atlantic Monthly, Feb., 1894, vol. 73, pp. 222-223.'

Poems, Cambridge Edition, 1895.

Not in Riverside Edition.

Parson Tureli's Legacy: or The President's Old Arm-Chair.

A Mathematical Story

Atlantic Monthly, Oct., 1858, vol. 2, pp. 626-628, in the "Autocrat."

Autocrat of the Breakfast-Table, 1858, pp. 345-349.

Songs in Many Keys, 1862.

Parting Health to J. L. Motley, A. On his return to England after the publication of the Rise of the Dutch Republic

Autocrat of the Breakfast-Table, 1858, pp. 28-29. ${ }^{1}$

Songs in Many Keys, 1862.

This poem was read at a farewell dinner to Motley, Aug. 7, 1857. See Longfellow's Journal of that date in S. Longfellow's Life of H. W. L.

\section{Parting Hymn}

Atlantic Monthly, Aug., 1861, vol. 8, p. 235.

Songs in Many Keys, 1862.

Parting Song, The (1857) (At the Meeting of the Alumni of Harvard College)

Songs in Many Keys, 1862.

Parting Word, The

Western Messenger, May, 1838.

Poems, London, 1846.

Peabody, George

See "To George Peabody."

${ }^{1}$ Not included in the "Autocrat" when that work appeared in the Atlantic Monthly. 


\section{Peau de Chagrin of State Street, The}

Atlantic Monthly, March, 1890, vol. 65, p. 403, in "Over the Teacups."

Over the Teacups, 1890, pp. 73-74.

Poems, Riverside Edition, 1891.

Peirce, Benjamin: Astronomer, Mathematician. 1809-1880 ${ }^{1}$ (Read at the Class Meeting, Jan. 6, 1881)

Atlantic Monthly, Dec., 1880, vol. 46, pp. 823-824.

Benjamin Peirce. A Memorial Collection, 1881, pp. 63-64.

Additional Songs and Poems of the Class of 1829, 1881, pp. 196-197.

Poems, Handy Volume Edition, 1881.

Phi Beta Kappa Society, Harvard

See "An After-Dinner Poem," "Chanson without Music,"

"A Poem Served to Order," "Poetry: a Metrical Essay," "PostPrandial," "Terpsichore," "To the Poets who only Read and Listen," "Verses for After-Dinner."

Phi Beta Kappa Society, Yale

See "Astræa."

Philosopher to his Love, The

The Token and Atlantic Souvenir, 1833, pp. 310-311.

Poems, 1836.

Pilgrim's Vision, The

C. J. Fox's History of the Old Township of Dunstable, etc. (Nashua), 1846, pp. 51-54.

W. S. Russell's Guide to Plymouth and Recollections of the Pilgrims, 1846, supp. pp. 73-74.

Poems, 1849.

The diary of Dr. John Pierce has the following entry concerning the anniversary celebration of the Landing of the Forefathers at Plymouth, Dec. 22, 1845: "Dr. Oliver Wendell Holmes next read a beautiful poetical effusion suited to the occasion." Dr. Pierce copied "The Pilgrim's Vision" in full into his diary. (Proceedings of Mass. Hist. Soc., 2d series, vol. 10, pp. 399-400.)

Pittsfield Cemetery, Dedication of

See "Poem for the Dedication," etc.

' Printed in first impression of Riverside Edition, vol. xii, "1809-1890." 


\section{[ 58 ]}

Ploughman, The (Anniversary of the Berkshire Agricultural Society, Oct. 4, 1849)

Poems, London, 1852.

Songs in Many Keys, 1862.

The Poet among the Hills (J. E. A. Smith), 1895, pp. 132-133.

'In the last-named volume the poem is said to be given as originally delivered, and the title is spelled "Plowman." The following variations from the text of the poem as now printed may be noted. The last two lines of the $3 \mathrm{~d}$ stanza read:

"There are the lines, oh, Heaven-commanded toil, That fill thy deed - the charter of the soil!"

Line 12 of the 4th stanza:

"Round the fresh clasp of thine embracing arms."

Lines 3-6 of the last stanza:

"By yon twin crests, amid the sinking sphere,

Last to dissolve and first to reappear,

By these fair plains the mountain circle screens, And feeds in silence from its dark ravines."

And the last two lines of the poem:

"Till Greylock thunders to the setting sun,

The sword has rescued what the ploughshare won."

Poem at the Dedication of the Halleck Monument (July $8,1869)$

8 vo leaflet, pp. 4; third and fourth pages blank.

A copy of the leaflet, with Dr. Holmes's autograph, brought $\$ 25.00$ at the William Harris Arnold Sale in 1901 .

Songs of Many Seasons, 1875.

A description of the Dedication of the Monument, erected at Guildford, Conn., in honor of Fitz-Greene Halleck (privately printed), 1869. See Appendix, p. 309, infra.

Poem for the Centennial Dinner of the Massachusetts Medical Society, June 8, 1881

Boston Medical and Surgical Journal, June 23, 1881, vol. 104, pp. 577-580.

Poems, Handy Volume Edition, 1881.

The original ms. of this poem is owned by the Massachusetts Medical Library Association. 
Poem for the Dedication of the Fountain at Stratford-onAvon (1887)

Story of the Memorial Fountain to Shakespeare at Stratfordupon-Avon, given by George W. Childs, L. Clarke Davis, editor (privately printed), 1890 , pp. $41-44 .^{1}$

Poems, Riverside Edition, 1891.

As originally published in the newspapers, "Blandusia" was printed instead of "Bandusia," in line 4 of the $2 d$ stanza. See “After Our Hundred Days," Atlantic Monthly, vol. 61, p. 129.

Poem for the Dedication of the Pittsfield CemeTERY, A

An Address by Rev. Henry Neill and a Poem by Oliver Wendell Holmes, etc., 1850, pp. 55-60.

A copy of this pamphlet was sold by Bangs, in April, 1897, for $\$ 5.00$.

Poems, London, 1852.

Songs in Many Keys, 1862.

Printed under the title "Woodlawn Cemetery" in Memory and Hope, Marian C. D. Silsbee, editor, 1851.

Poem for the Meeting of the American Medical Association, A

Response of Oliver Wendell Holmes, M. D., to the following toast, proposed at the Entertainment given to the American Medical Association, by the Physicians of the City of New York, at Metropolitan Hall, on the 5th of May, 1853. Toast. - "The Union of Science and Literature-a happy marriage, the fruits of which are nowhere seen to better advantage than in our American Holmes." - Broadside, large folio, 1 page.

Songs in Many Keys, 1862.

${ }^{1}$ On page 22 is the following letter:

DeAR Mr. Childs:

I have written a poem for the celebration of the opening of the fountain. There are nine verses, each of nine lines, as it now stands. I mean to revise it carefully, transcribe it, and send you the copy in the course of the week.

I have taken pains with it, and I hope you will like it. Please do not take the trouble of replying before you get the poem.

Always truly yours,

O. W. Holmes. 


\section{[60 ]}

Poem for the Two Hundred and: Fiftieth Anniversary of Harvard College

Record of the Commemoration, November fifth to eighth, 1886, etc. (1887), pp. 237-249.

Atlantic Monthly, Dec., 1886, vol. 58, supp. pp. 18-28.

Before the Curfew, and Other Poems, 1888.

Poem read at the Dinner given to the Author by the Medical Profession of the City of New York

Proceedings at the Dinner, etc., April 12, 1883, Wesley M. Carpenter, editor, 1883, pp. 16-23.

Poems, Cambridge Edition, 1895.

A head-note to the group Medical Poems, in the Cambridge Edition, states that this poem was accidentally omitted from the Riverside Edition.

Poem Served to Order, A (థ. B. K., June 26, 1873)

Atlantic Monthly, Sept., 1873, vol. 32, pp. 296-297.

Songs of Many Seasons, 1875.

Poet to the Readers, The

Atlantic Monthly, July, 1862, vol. 10, pp. 118-119.

Poems, Blue and Gold Edition, 1862.

Printed in this and all subsequent collected editions, as a Prelude, under the title, "To my Readers."

\section{Poet's Lot, The}

Poems, 1836.

First appeared in [Buckingham's] New England Magazine, vol. 1, p. 239, under the title, "Thoughts in Dejection."

* Poet's Reply, The (To a request to contribute to Our Daily Fare)

Our Daily Fare, Philadelphia, June 9, 1864, no. 2, p. 13.

Why in these breathless sleepless times,

When every hour is like an age,

Should poets pair the rusted rhymes

That climb in every school-boy's page?

Are these the days for idle songs?

Are these the nights to doze and dream, 


\section{[61 ]}

When all our fiery manhood throngs

A perilled nation to redeem?

Yet blame not him whose slender tone

Blends with the stirring battle-call;

'T was but a crooked ram's horn blown, -

Down crushed the Godless heathen's wall!

A word of cheer may nerve the blow

That turns the conflict's trembling scale,

And he that never saw his foe

May pierce him through his triple mail.

Poetry: a Metrical Essay (Read before the Phi Beta Kappa Society, Harvard University, Aug., 1836)

Poems, 1836, pp. 3-39.

Dr. John Pierce, of the Harvard Class of 1793, for many years a regular attendant at Commencement and at Phi Beta Kappa meetings, left a diary from which copious extracts have been published from time to time in the Proceedings of the Massachusetts Historical Society. He had this to say of the meeting of 1836: "After a suitable interlude by the band, Oliver Wendell Holmes, M. D., of the class of 1829, delivered a beautiful poem of 1 hour and 10 minutes, committed to memory, and uttered with charming ease and propriety. It was exceedingly miscellaneous. In it he paid a feeling tribute to this as the place of his nativity, to some of the most striking objects in his vicinity, and to his sister, who in the bloom and beauty of youth was consigned to the adjoining cemetery. He took an affectionate notice of Dr. James Jackson, Jr., ${ }^{1}$ with whom he had studied in Paris, and whose early death he deeply deplored. He was often interrupted by the spontaneous and long continued applauses of the Society and of the audience in general." (Mass. Hist. Soc. Proceedings, 2d series, vol. 9, p. 127.) See "Lines recited at the Cambridge Phi Beta Kappa Dinner" and "The Pilgrim's Vision."

"A few lines, perhaps deficient in dignity," have been, from the beginning, omitted from the poem as published, but printed among the "notes."

${ }^{1}$ See Dr. Holmes's letter from Paris to Dr. James Jackson, Senior, in Dr. James Jackson Putnam's Memoir of Dr. James Jackson, 1905, pp. 314-316. 


\section{[62 ]}

Poetry of Real Life

See "The Flies."

Portrait, $\mathbf{A}$

The Token and Atlantic Souvenir, 1833, p. 337.

Poems, 1836.

* Portrait of a Lady (The Athenæum Gallery)

"Lady! I may not see thy face."

The Amateur, June 15, 1830, no. 1, p. 16.

Post-Prandial (Phi Beta Kappa, 1881)

Atlantic Monthly, Sept., 1881, vol. 48, p. 365.

Poems, Riverside Edition, 1891.

The orator of the day was Wendell Phillips and the poet Charles Godfrey Leland (Hans Breitmann). An interesting letter from Dr. Holmes to Mr. Leland on the subject of the latter's poem and the reception accorded it, may be found in Mrs. E. R. Pennell's Charles Godfrey Leland, 1906, vol. ii, pp. 116-118.

Poultry (The Athenæum Gallery)

The Amateur, July 3, 1830, no. 2, p. 25.

See "A Noontide Lyric."

[Prelude]

"I'm the fellah that tole one day."

Atlantic Monthly, Oct., 1858, vol. 2, p. 625, in the "Autocrat."

Autocrat of the Breakfast-Table, 1858, p. 344.

Poems, Cambridge Edition, 1895.

This introduction to "Parson Turell's Legacy," alone of all the poems in the "Autocrat," was never printed in any collection of poems prior to the Cambridge Edition.

Prelude to a Volume printed in Raised Letters for the Blind

Selections from the Poetical Works of Dr. Oliver Wendell Holmes, in raised letters, Howe Memorial Press, Boston, 1885 , p. v.

Before the Curfew, and Other Poems, 1888.

Prelude to Verses from the Island Book

See p. 208, infra. 


\section{[63 ]}

President's Old Arm-Chair, The

See "Parson Turell's Legacy."

\section{Programme}

Songs of Many Seasons, 1875, pp. iv-vii, dated Oct. 7, 1874.

[Prologue]

"A prologue? Well, of course the ladies know."

Atlantic Monthly, Dec., 1857, vol. 1, pp. 182-183, in the "Autocrat."

Autocrat of the Breakfast-Table, 1858, pp. 49-52.

Songs in Many Keys, 1862.

In last-named volume first printed with title. A portion of this poem was printed by Mr. R. W. Emerson in his "Parnassus" (Boston, 1874), under the title, "Rudolph the Headsman."

\section{[Prologue]}

"The piping of our slender, peaceful reeds."

Songs in Many Keys, 1862, p. v.

$\checkmark \quad$ Here, and in all collected editions previous to the Riverside, 1891 , printed as a prologue to Songs in Many Keys, but without separate title.

Promise, The

Songs in Many Keys, 1862.

\section{Questions and Answers}

Poems of $1849,2 \mathrm{~d}$ issue.

Songs of the Class of 1829, 1854, pp. 10-11.

In his Life and Letters of Oliver Wendell Holmes, Mr. Morse quotes letters of Rev. Samuel May, Secretary of the Class of 1829, to Dr. Holmes, as follows: "You regularly began to furnish us a poem in 1851, - 'The summer dawn is breaking' [A Song of Twenty-Nine]." - "From that day to this no class meeting of 1829 has been without a poem from you - not one." It is true, none the less, that there was no contribution from Dr. Holmes in 1852. "Questions and Answers," which had been printed in 1849, was sung by him at the meeting in 1850; it was printed among the Class songs in 1854, and in the second edition (1859) was relegated to the Appendix, with the words "From Dr. Holmes's Poems." In the third edition (1868), it took its place as of 1852 , although with a slightly different designation 


\section{[64 ]}

from the other poems ("For the Class, 1852"), and has been so printed in all collected editions since 1877, although it was originally written much earlier than 1852 , and not for the Class.

Qui Vive

American Monthly Magazine, Nov., 1836, n. s. vol. 2, pp. 468-469.

Poems, 1836.

Readings over the Teacups. Five Stories and a Sequel

Poems, Riverside Edition, 1891.

Poems, Cambridge Edition, 1895.

To my Old Readers.

The Banker's Secret.

The Exile's Secret.

The Lover's Secret.

The Statesman's Secret.

The Mother's Secret.

The Secret of the Stars.

There are also interludes between each two of the poems (excluding "To my Old Readers"), which had never before been printed. See "Each Heart has its own Secret."

Reflections of a Proud Pedestrian

The Collegian, May, 1830, no. 4, p. 199.

Poems, 1836.

Remember - Forget (Written for the Class Meeting, Jan. 10, 1856)

Songs and Poems of the Class of 1829, 1859, pp. 17-19.

The title here is "Song," simply.

Poems, Household Edition, 1877.

Response of Oliver Wendell Holmes to the folLOWING Toast, etc.

See "Poem for the Meeting of the American Medical Association," May 5, 1853.

Rhymed Lesson, $\mathbf{A}$

See "Urania ; a Rhymed Lesson."

Rhymed Riddle, A

Fair Words, 1876. See Appendix, p. 309, infra. 


\section{[65 ]}

Rhymes of a Life-Time (Aug. 2, 1881)

Poems, Riverside Edition, 1891.

Originally appeared, without title, as a Prelude to Poems, Handy Volume Edition, 1881.

*[Riddle]

Fair Play, 1875, p. 3.

This is a book of riddles, compiled for sale at a fair in Waltham, Mass. Pamphlet, 16mo, pp. 20. Dr. Holmes's contribution is Number I ("by permission").

My name declares my date to be

The morning of a Christian year.

Though motherless, as all agree,

I am a mother, it is clear;

A father, too, without dispute,

And when my son comes, - he's a fruit.

And, not to puzzle you too much,

'T was I gave Holland to the Dutch.

The answer is "Adam." A copy of Fair Play, with an autograph letter from Dr. Holmes inserted, was sold at the William Harris Arnold Sale in 1901, for $\$ 12.00$; another copy at the Pyser Sale in 1906, for $\$ 11.00$.

Rip Van Winkle, M. D. An After-Dinner Prescription taken by the Massachusetts Medical Society, at their meeting held May 25, 1870

Boston Medical and Surgical Journal, June 9, 1870, n. s. vol. 5 , pp. 444-446. ${ }^{1}$

Songs of Many Seasons, 1875.

Robinson of Leyden

Atlantic Monthly, July, 1859, vol.4, p. 128, in the "Professor."

Illustrated Pilgrim Almanac for 1860, p. 20.

Professor at the Breakfast-Table, 1859, pp. 220-221.

Songs in Many Keys, 1862.

1 "In placing at the head of the Editor's table the following poem, read by $\mathrm{O}$. W. Holmes, at the recent dinner of the Massachusetts Medical Society, we attain the object of our hunger and thirst. We had failed to secure it by our own syren songs of persuasion, though attuned to their most dulcet notes. But the following letter from the poet's former friends in the profession in Berkshire was too much for his obduracy - and here we have it." 


\section{[66 ]}

Roman Aqueduct, A

Poems, 1836.

See "The Claudian Aqueduct."

* Romance

The Collegian, March, 1830, no. 2, p. 60.

\section{Rose, The, and the Fern}

Atlantic Monthly, April, 1890, vol. 65, p. 560, in "Over the Teacups."

Over the Teacups, 1890, p. 118.

Poems, Riverside Edition, 1891.

\section{Rudolph the Headsman}

Parnassus, R. W. Emerson, editor, 1875.

Taken from the poem in the "Autocrat" beginning: "A prologue? Well, of course the ladies know." See ["Prologue"].

\section{* Runaway Ballads I and II}

The Collegian, Feb., 1830, no. 1, pp. 11-12.

As these are the earliest in date of those poems of Dr. Holmes which it has been found possible to trace (except the translation from the Eneid, "First Verses"), they are here given at length.

\section{I}

Wake from thy slumbers, Isabel, the stars are in the sky, And night has hung her silver lamp, to light our altar by; The flowers have closed their fading leaves, and droop upon the plain,

$O$ wake thee, and their dying hues shall blush to life again.

In such a sacred hour as this, how beams the eye of love, When all is mellowed shade below, and all is light above; And oh, how soft a maiden's sigh melts on the midnight air, When scarce a wanton zephyr breathes, to wave her silken hair.

The rattle of the soldier's steel has left the silent hall, The mastiff slumbers at the gate, the sentry on the wall; And there, by many a stately barge, that rocks upon the tide, A bark is floating on the waves and dancing by their side. 
And when before the flowing wind she spreads her eagle wings, And like a halcyon, from her breast the shivered billow flings; Though many a prouder pendant flies before the ocean breeze,

No keel can track her foaming path, that sweeps the sparkling seas.

Then come to me, my lovely one, and haste we far away, And we will reach the distant isle before the break of day; Let not thy gentle eyes grow dim, thy rosy cheek grow pale, For thou shalt find a beating heart beneath a warrior's mail.

\section{II}

Get up! get up! Miss Polly Jones, the tandem's at the door;

Get up, and shake your lovely bones, it's twelve o'clock and more,

The chaises they have rattled by, and nothing stirs around, And all the world, but you and I, are moving safe and sound.

I broke a drunken watchman's nap, and he began to mutter, I gave him just a gentle tap, that helped him to the gutter;

The cur-dog growled an ugly growl, and grinned a bitter grin;

I tipped the beast a rat's-bane pill, to keep his music in.

When Squaretoes stumps about the house, and does n't find you there,

And all the folks are in a touse, my eyes! how dad will stare! He locked and double-locked the door, and saw you safe abed, And never dreamed a jailor's paw could scratch a booby's head.

Come hurry! hurry! Polly Jones, it is no time to snooze;

Don't stop for t'other petticoat, nor fidget for your shoes;

I have a quilted wrapper here, your tender limbs to fold,

It's growing mighty chilly, dear, and I shall catch a cold.

I've got my gouty uncle's bay, and trotting Peggy too,

I've lined their tripes with oats and hay, and now for love and you;

The lash is curling in the air, and I am at your side,

To-morrow you are Mrs. Snaggs, my bold and blooming bride. R[ussell], J[ames] D[utton] (Read at the Class Meeting, Jan. 23, 1862)

Songs and Poems of the Class of 1829, 1868, p. 63.

Poems, Household Edition, 1877.

In the former, under the title "In Memory of J. D. R." 


\section{[68 ]}

Sabbath in Boston, A

The Rosary of Illustrations of the Bible, 1848.

A passage from "Urania: a Rhymed Lesson."

Saint Anthony the Reformer - His Temptation

Atlantic Monthly, Aug., 1859, vol. 4, p. 24.3, in the "Professor."

Professor at the Breakfast-Table, 1859, pp. 255-256.

Songs in Many Keys, 1862.

Sargent, Howard

See "H. C. M., H. S., J. K. W."

* Scenes from an Unpublished Play

The Collegian, March, 1830, no. 2, pp. 61-62; April, no. 3. pp. 138-140; July, no. 6, pp. 265-268.

* Sceptres and thrones the morning realms have tried

See Appendix, p. 310, infra.

School-Boy, The

The Iron Gate, and Other Poems, 1880.

* Scintilla, A

Addresses at the Inauguration of Jared Sparks, LL. D., as

President of Harvard College, June 20, 1849, p. 11.

The author's name is not suggested here, but a printed copy of the poem, preserved in the Harvard College Library, has written upon it the words, "Written by O. W. Holmes."

THE TASK

Twelve well-crammed lines, firm, juicy, marrowy, sweet,

No bone or trimmings, nothing here but meat,

With rhyme run through them like a golden skewer,

Taste might approve and patience may endure.

THE EXECUTION

Long live old Harvard! Lo, her rushing train

Greets a new sign-board stretched across the plain;

While the bell rings - (and that the bell shall do

Till Charles shall drop his worn-out channel through,) -

It gently hints to every cur that barks,

Here comes the engine, - don't you see the Sparks? 


\section{[69 ]}

How changed the scene! The forest path is clear;

That mighty engine finds no Indian here!

The world's great teachers quit their native Alps

To fill the skulls once trembling for their scalps,

When the red neighbors of our ancient school

Left their own wigwams others' wigs to cool!

\section{Sea Dialogue, A}

The Boatswain's Whistle (published at the National Sailors'

Fair), November 12, 1864, no. 4, p. 27.

Poems, Household Edition, 1877.

Secret of the Stars, The

Songs in Many Keys, 1862, as one of the group Pictures

from Occasional Poems; so in

Poems, Household Edition, 1877.

Poems, Riverside Edition, 1891.

See "Each Heart has its own Secret."

Semi-centennial Celebration of the New England Society in New York, Dec. 22, 1855

Pamphlet of above title, 1856 , pp. 83-84; preceded by remarks by Dr. Holmes, pp. 82-83.

Songs in Many Keys, 1862.

The New England Society Orations. Addresses, Sermons and Poems, etc., 1901, pp. 269-270.

Sentiment, A

"The pledge of Friendship! it is still divine."

Poems, 1849.

Sentiment, A (Written for the Eighth Anniversary of the American Medical Association)

"A triple health to Friendship, Science, Art."

Leaflet.

Boston Medical and Surgical Journal, May 17, 1855, vol. 52, p. 305.

Songs in Many Keys, 1862.

In last-mentioned volume first printed with title.

Sentiment, A

See "Extracts from a Medical Poem." 


\section{$[70]$}

September Gale, The

Poems, 1836.

Shadows, The (Written for the Class Meeting, Jan. 8, 1880)

The Iron Gate, and Other Poems, 1880.

Additional Songs and Poems of the Class of 1829, 1881, pp. 192-194.

Shakespeare Tercentennial Celebration (April 23, 1864)

Atlantic Monthly, June, 1864, vol. 13, pp. 762-763.

Songs of Many Seasons, 1875.

Sherman's in Savannah! a Half-Rhymed Impromptu

(Written for Class Meeting, Jan., 1865)

Songs and Poems of the Class of 1829, 1868, p. 83.

Songs of Many Seasons, 1875.

Ship of State, The (Woodstock, Conn., July 4, 1877)

Poems, Household Edition, 1877.

Read on the same occasion as "A Family Record."

Silent Melody, The

Atlantic Monthly, Sept., 1878, vol. 42, p. 335.

The Iron Gate, and Other Poems, 1880.

* Six Verses

[Buckingham's] New England Magazine, July, 1833, vol. 5, p. 44.

Smiling Listener, The (Written for the Class Meeting, Jan. 5, 1871)

Songs of Many Seasons, 1875.

The date, 1871, is given correctly in the Contents, but in the text it is given as 1872 .

Additional Songs and Poems of the Class of 1829, 1881, pp. 137-140.

In last-mentioned volume printed with no other title than "Lines."

Smith, Rev. Samuel F., D. D.

See "To the Reverend S. F. Smith, D.D."

Song for the Centennial Celebration of Harvard College, A

Poems, 1849, 2d issue. 


\section{[71 ]}

"This song, which I had the temerity to sing myself (felix audacia, Mr. Franklin Dexter had the goodness to call it), was sent in a little too late to be printed with the official account of the celebration. It was written at the suggestion of Dr. Jacob Bigelow, who thought the popular tune 'The Poacher's Song' would be a good model for a lively ballad or ditty." - Note of Dr. Holmes in Riverside Edition of Poems.

Song for a Temperance Dinner to which Ladies were Invited

Poems, Household Edition, $187 \%$.

Originally printed as "Song, written for the Annual Dinner of the New York Mercantile Library Association," in Poems, 1846.

\section{Song of Other Days, A}

Poems, 1849.

Sung by Dr. Holmes to the Class of 1829, at its meeting at Commencement, 1847.

* Song of the Henpecked

The Amateur, Oct. 1, 1830, no. 7, p. 116.

Song of "Twenty-Nine," A (Written for the Annual Meeting, 1851)

Broadside, pp. 4 (page 4 blank), dated Jan. 2, 1851.

Songs of the Class of 1829, 1854.

Poems, Household Edition; 1877.

This was really the first of the long series of poems written by Dr. Holmes expressly for the meetings of the Class of 1829 . It was written in response to a unanimous vote of the Class, passed at the meeting of 1850, and was sung in 1851 to the tune of "The Bay of Biscay, O!" See "Questions and Answers."

\section{* Song of Welcome}

Complimentary Banquet given by the City Council of Boston to Rear-Admiral Lessoffsky and the Officers of the Russian Fleet, at the Revere House, June 8, 1864, p. 57.

See Appendix, p. 310, infra.

Sea-birds of Muscovy, rest in our waters,

Fold your white wings by our rock-girded shore;

While with glad voices its sons and its daughters

Welcome the friends ye have wafted us o'er. 


\section{[72]}

Sea-kings of Neva, our hearts throb your greeting!

Deep as the anchors your frigates let fall;

Down to the fount where our life-pulse is beating, Sink the kind accents you bear to us all.

Fires of the North, in eternal communion, Blend your broad flashes with evening's bright star !

God bless the Empire that loves the great Union; Strength to her people! Long life to the Czar!

Song, written for the Annual Dinner of the New York Mercantile Library Association [1842]

Poems, London, 1846.

See "Song for a Temperance Dinner to which Ladies were Invited."

Song, written for the Dinner given to Charles Dickens by the Young Men of Boston [1842]

Report of the Dinner given to Charles Dickens, in Boston, February 1st, 1842,p. 33. (Sung to the air "Gramachree.")

Poems, London, 1846.

A copy of this poem, printed on a folio sheet, presumably for distribution at the dinner, was sold at Anderson's in Oct., 1902, for $\$ 8.25$.

Souvenir, A

American Monthly Magazine, Nov., 1836, n. s. vol. 2, pp. 498-499.

Poems, 1836.

Poems, Cambridge Edition, 1895.

Not in Household or Riverside Edition.

Spectre Pig, The

The Collegian, May, 1830, no. 4, pp. 180-182.

Poems, 1836.

\section{Spring}

Songs in Many Keys, 1862.

"Spring," like "The Study," "The Bells," "Non-Resistance," "The Moral Bully," "The Mind's Diet." and "Our Limitations," was originally a part of the long poem, "Astræa: the Balance of Illusions," delivered before the Yale Phi Beta 


\section{[73 ]}

Kappa in 1850, and printed in that year in pamphlet form. These extracts were printed in Songs in Many Keys under the group heading, Pictures from Occasional Poems, which has been retained in the Household Edition, but was discarded in the Riverside Edition, 1891.

\section{Spring has Come - Intra Muros}

Atlantic Monthly, June, 1858, vol. 2, pp. 110-111, in the "Autocrat."

Autocrat of the Breakfast-Table, 1858, pp. 228-230.

Songs in Many Keys, 1862.

Stability of Science, The

See "Extracts from a Medical Poem."

\section{Stanzas}

"Strange! that one lightly whispered tone."

The Collegian, July 30, no. 6, p. 268.

The Harbinger, 1833, pp. 60-61.

Poems, 1836.

Star, The, and the Lily

The Amateur, Oct. 1, 1830, no. 7, p. 105.

Star, The, and the Water-Lily

Poems, 1836.

Originally appeared, under the title "The Star and the Lily," in the Amateur, as above.

* Star-Spangled Banner, The. Additional verse

Sheet music, 4to. Published by Oliver Ditson \& Co. [c. 1861].

When our land is illum'd with liberty's smile,

If a foe from within strike a blow at her glory,

Down, down, with the traitor that dares to defile

The flag of her stars and the page of her story.

By the millions unchain'd who our birthright have gained,

We will keep her bright blazon forever unstained.

And the star-spangled banner in triumph shall wave

While the land of the free is the home of the brave.

This stanza was sung by “Our Sweet Singer” (Mr. Angier) at the Class Meeting of Jan. 8, 1863. 


\section{[74 ]}

State Prison Melodies

See "The Treadmill Song."

Statesman's Secret, The

Poems, Riverside Edition, 1891, in "Readings over the Teacups."

Poems, Cambridge Edition, 1895.

Originally printed, under the title "The Disappointed Statesman," as one of the group Pictures from Occasional Poems, in Songs in Many Keys, 1862, and still so printed in Household Edition. See "Each Heart has its own Secret."

Steamboat, The

The Boston Book, 1841, pp. 25-27.

Poems, London, 1846.

Stethoscope Song, The

Poems, 1849.

Stratford-on-Avon, Dedication of the Fountain at

See "Poem for the Dedication," etc.

Study, The

Songs in Many Keys, 1862.

See note to "Spring."

Sumner, Charles, Hymn at the Funeral Services of

See "Hymn at the Funeral Services," etc.

Sun and Shadow

Atlantic Monthly, Dec., 1857, vol. 1, p. 181, in the "Autocrat." Autocrat of the Breakfast-Table, 1858, pp. 45-46.

In last-mentioned volume first printed with title.

Songs in Many Keys, 1862.

Sun-Day Hymn, A

Atlantic Monthly, Dec., 1859, vol. 4, p. 766, in the "Professor."

Professor at the Breakfast-Table, 1859, pp. 402-403.

Songs in Many Keys, 1862.

* Sunset Scene (The Athenæum Gallery)

The Amateur, July 3, 1830, no. 2, p. 24.

Swain, W. W.

See "The Last Look." 
Sweet Little Man, The

Songs in Many Keys, 1862.

* Tail-Piece, The

The Collegian, July, 1830, no. 6, pp. 289-290.

This poem closed the sixth and last number of the Collegian. It is introduced by these words: "We subjoin the following poetical finale, written by our most valued correspondent at the request of the Club."

Kind world, sweet world, on every earthly shore,

From Boston's dome to China's porcelain tower,

We bend our knee in lowly guise once more,

To ask a blessing on our parting hour.

Our bud was nursed in Winter's tempest roar,

The dews of spring fell on the opened flower;

The stem is snapped, and blue-eyed Summer sees

Our lilac leaflets scattered to the breeze.

No more we float upon the tide of time,

That fills the chalice of the star-girt moon;

The sober essay and the sounding rhyme

Are as the echoes of a ceasing tune;

From neighboring village and from distant clime,

From bare-walled study and from gay saloon,

We softly sink to dark oblivion's shade,

Unwept, unblest, unhonored, and unpaid.

The vagrant printer may resume his quill,

To scribble school-boy on the nameless tomb;

The hard-eyed pedant call us, if he will,

Precocious children, nursed to fruitless bloom;

The sad subscriber eye his tardy bill,

And knit his brows in unavailing gloom -

The printer's satire and the pedant's frown,

The debtor's sigh, we swallow boldly down.

But thou, sweet maiden, as thy fingers turn

The last poor leaf that claims thine idle glance,

If there was aught to feel or aught to learn

In ode or treatise, vision, dream, or trance, -

If the cold dust of the neglected urn

Has ever warmed thee, by some happy chance, 


\section{[ 76 ]}

Should aunts look grim, or fathers shake the head, Plead for the harmless ashes of the dead.

Ethereal being, thou whose melting eye

Looks down like heaven where'er its glances fall,

On noiseless slipper, gliding softly by,

So sweetly drest, so proper, and so tall,

The dew-fed offspring of the summer sky,

Beau, critic, poet, soldier, each and all,

From the dormeuse, where thy soft limbs recline,

Sigh out a requiem o'er our broken shrine.

The fire is out - the incense all has fled;

And will thy gentle heart refuse to grieve?

Forget the horrors of the cap-crowned head,

The fatal symbol on a student's sleeve,

Think that a boy may grow if he is fed,

And stroke us softly as we take our leave;

Say we were clever, knowing, smart, or wise,

But do say something, if you $d-n$ our eyes.

Ye who have shrunk not, dangerous though it seem,

To lay your hands on yet unlaureled brows, If e'er we meet - and frown not if we deem

Fame yet may smile on boyhood's burning vows -

Bound in the garlands that we fondly dream

May yet be gathered from Parnassian boughs;

Yours be the praise, who led our doubtful way,

Till harmless Hatred threw his brick away.

Perchance we greet you, not as late we came,

In meagre pamphlet, bound in flimsy fold,

But from a page that bears a prouder name,

With silken covers and with edge of gold;

Look then in kindness on our higher claim

And bid us welcome as ye did of old;

So may your lives in pleasure glide along,

Rich as our prose, and sweeter than our song.

Peace with you all - the summer sun will rise

Not less resplendent that we are no more;

The evening stars will gird the arching skies,

The winds will murmur, and the waters roar - 


\section{[ 77 ]}

Our faded way is lost to mortal eyes,

Our wave has broken on the silent shore -

One whisper rises from the weeping spray -

Farewell, dear readers - and be sure to pay.

\section{Tartarus}

Atlantic Monthly, Sept., 1890, vol. 66, pp. 399-400, in " Over the Teacups."

Over the Teacups, 1890, pp. 259-260.

Poems, Riverside Edition, 1891.

Terpsichore (Phi Beta Kappa, Harvard, Aug. 24, 1843)

Graham's Magazine, ${ }^{1}$ Jan., 1844, vol. 24, pp. 10-11.

Poems, London, 1846.

See "An After-Dinner Poem."

1 See Passages from the Correspondence and Other Papers of Rufus W. Griswold (Cambridge, 1898), p. 146, where the following letter to Mr. Griswold, editor of Graham's, relating to this poem, is printed:-

MY DEAR SiR:

Boston, Sept. 1st, 1843.

I read a Poem at the dinner table of the Phi Beta Kappa at Cambridge the other day which I should like to publish in Graham's Magazine, if the editors want it and are willing to pay for it.

It consists at present of $\mathbf{1 6 6}$ lines in the heroic measure - but I should be inclined to make it about two hundred, or very nearly that, by certain additions. I believe that for me it was remarkably happy, but you may think it no great thing. At any rate it has more point in it than most of the things of the kind I have done lately.

Two or three weeks ago Mr. Frost, on the part of Godey's Lady's Book, made me some liberal offers for anything I would give him. I answered that I felt bound to offer them to you first, but without the least idea that I should so soon have anything to publish. I therefore mention it to you and end my proposals with these questions:

1. Do you want such a poem?

2. What will you give me for it?

3. Are you afraid of a hint at repudiation in it?

4. Can it be published in your Magazine word for word, letter for letter, comma for comma?

5. Do you want to see it before you meddle with it?

This is a very straight-forward business letter, and does not require any answer unless you want the Poem. If so I shall hear from you. Believe me very truly

\section{Your Friend,}

O. W. Holmes.

P. S. No tender feelings are concerned which might interfere with Editorial interests. 


\section{[ 78 ]}

* "This evening hour, which grateful memory spares"

Pamphlet, 16mo, pp. 8.

Boston Medical and Surgical Journal, Oct. 11, 1894, vol. 131, pp. 377-379.

A footnote in the Journal informs us that this poem, some lines of which are omitted, "was read at a medical supperparty about forty-eight years ago;" and on the first page of the pamphlet is the following note: "These verses were read at a medical supper-party about the year 1845."

There is nothing to indicate when the pamphlet was printed. Copies have been sold at auction as follows: Libbie's, 1890, $\$ 12.00$; Arnold Sale, 1901, $\$ 14.00$; Drury Sale, 1906, $\$ 15.50$. The Boston Medical Library Association owns a pamphlet copy of the poem; also a manuscript copy, formerly owned by the late Dr. James R. Chadwick.

* This shrine a precious gift enfolds

Memoir of Dr. James Jackson, by Dr. James J. Putnam, 1905, pp. 414-415.

These verses accompanied the gift of a set of silver salt-cellars to Dr. Jackson on his eightieth birthday, Oct. 3, 1857.

This shrine a precious gift enfolds;

Look, when its lids unclose,

Not on the shining cross it holds,

But on the love it shows.

What though the silvered brow may seem

Amid the youthful throng

A little farther down the stream

That bears us all along;

Those murmuring waves are mute to-day,

The stream forgets to run,

The brown locks mingle with the gray,

And all our hearts are one.

Ah, could we bring earth's sweetest song

And bear its brightest gold,

The gift our grateful hearts would wrong,

Our love were still untold. 
* Thoughts in Dejection

[Buckingham's] New England Magazine, Sept., 1831, vol. 1, p. 239.

The Harbinger (1833), pp. 51-52.

Thus Saith the Lord (1862)

Songs of Many Seasons, 1875.

To a Blank Sheet of Paper

The Amateur, July 17, 1830, no. 3, pp. 39-40.

Poems, 1836.

\section{To a Caged Lion}

The Collegian, April, 1830, no. 3, p. 103.

* To a Lady with her Back to Me

[Buckingham's] New England Magazine, Nov., 1831, vol. 1, p. 429; in the first "Autocrat of the Breakfast-Table," pt. i.

I know thy face is fresh and bright, Thou angel-moulded girl;

I caught one glimpse of purest white, I saw one auburn curl.

$O$ would the whispering ripples breathe The thoughts that vainly strive She turns - she turns to look on me; Black! cross-eyed! seventy-five!

To an English Friend

Poems, London, 1852. ${ }^{1}$

Songs in Many Keys, 1862.

To an Insect

[Buckingham's] New England Magazine, Sept., 1831, vol. 1, p. 235.

The Harbinger, 1833, pp. 53-55.

The Boston Book, 1836, pp. 229-230.

Poems, 1836.

To Canaan. A Puritan War-Song (Aug. 12, 1862) Songs of Many Seasons, 1875.

"This poem, published anonymously in the Boston Evening ${ }^{1}$ Printed as a sort of dedication of this edition. 


\section{[ 80 ]}

Transcript, was claimed by several persons, three, if I remember correctly, whose names I have or have had, but never thought it worth while to publish." - Note of Dr. Holmes in Riverside Edition.

To James Freeman Clarke (April 4, 1880)

Seventieth Birthday of James Freeman Clarke. Memorial of the Celebration by the Church of the Disciples, Monday, April 5, 1880, pp. 11-12.

The Iron Gate, and Other Poems, 1880.

See "A Birthday Tribute."

To Christian Gottfried Ehrenberg (For his Jubilæum at Berlin, Nov. 5, 1868)

Songs of Many Seasons, 1875.

\section{* To Fame}

[Buckingham's] New England Magazine, Nov., 1831, vol. 1, p. 430 ; in the first "Autocrat of the Breakfast-Table," pt. i.

They say thou hast a hundred tongues;

My wife has only one;

If she had been equipped like thee,

$\mathrm{O}$, what should I have done!

\section{The Echo}

Nay, dearest stranger, do not shout;

My wife has worn the echo out.

* To J[ohn] M[urray] F[orbes]. On his Eightieth Birthday, Feb. 23, 1813-Feb. 23, 1893

Letters and Recollections of John Murray Forbes (Sarah Forbes Hughes), 1899, vol. i, p. 35.

"It was this most genial of poets who wrote the verses given below, for the Saturday that fell next after my father's eightieth birthday, when they dined together at the [Saturday] club."

I know thee well. From olden time

Thou hadst a weakness for a rhyme,

And wilt with gracious smile excuse

The languor of a laggard muse,

Whose gait betrays in every line

The weight of years outnumbering thine. 


\section{[81 ]}

And who will care for blame or praise, When love each syllable betrays?

The seven-barred gate has long been past, The eighth tall decade cleared at last; But when its topmost bar is crossed Think not that life its charm hath lost; Ginger will still be hot in mouth, And winter winds blow sometimes south, And youth might almost long to take A slice of fourscore's frosted cake.

Thrice welcome to the chosen band, Culled from the crowd by Nature's hand:

No warmer heart for us shall beat, No freer hand in friendship meet.

Long may he breathe our mortal air, For heaven has souls enough to spare.

Lay at his feet the fairest flowers -

Thank God he still is Earth's and ours.

To R[utherford] B. H[ayes], Boston, June 26, 1877

Poems, Household Edition, 1877.

To Frederick Henry Hedge (At a Dinner given him on his Eightieth Birthday, Dec. 12, 1885. With a bronze Statuette of John of Bologna's Mercury, presented by a few friends)

Atlantic Monthly, March, 1886, vol. 57, p. 374, in "Two 'Occasional' Poems with an Introduction" ("The New Portfolio").

Before the Curfew, and Other Poems, 1888.

To H. W. Longfellow (Before his departure for Europe, May 27, 1868)

Songs of Many Seasons, 1875.

To J[ames] R[ussell] L[owell]

"This is your month, the month of 'perfect days." "

Atlantic Monthly, August, 1885, vol. 56, p. 263.

Before the Curfew, and Other Poems, 1888.

See "Two Anniversary After-Dinner Poems." 


\section{[82]}

To James Russell Lowell (At the Dinner given in his honor at the Tavern Club, on his Seventieth Birthday, Feb. 22, 1889)

Atlantic Monthly, April, 1889, vol. 63, pp. 556-558.

Poems, Cambridge Edition, 1895.

Not in Riverside Edition.

\section{To my Companions}

The Collegian, April, 1830, no. 3, pp. 122-123.

Poems, 1836.

Poems, Cambridge Edition, 1895.

Not in Household or Riverside Edition.

* To my Neighbour, Who Sings and Plays on the Pianoforte

The Amateur, April 23, 1831, no. 19, pp. 291-292. Signed O. W. H.

\section{To my Old Readers}

'Poems, Riverside Edition, 1891, as Prelude to "Readings over the Teacups."

Poems, Cambridge Edition, 1895.

\section{To my Readers}

Poems, Blue and Gold Edition, 1862.

Originally appeared, under the title "The Poet to the Readers," in Atlantic Monthly, July, 1862, vol. 10, pp. 118-119.

To George Peabody ${ }^{1}$ (Danvers, 1866)

The Iron Gate, and Other Poems, 1880.

To Governor Swain

Songs in Many Keys, 1862.

Printed under the title "Answer to an Invitation," in Verses from the Island Book, 1865, where the first line has skiff instead of bark.

"Governor "Swain (see "Island Hunting-Song," p. 40, supra) was an uncle of the wife of John M. Forbes, a later owner of Naushon island. The poem was written at Pittsfield in 1851, says Mr. Scudder.

${ }^{1}$ See Morse's Life and Letters of O. W. H., vol. ii, pp. 180-181. 


\section{[83 ]}

To the Eleven Ladies who presented me with a Silver Loving-Cup on the twenty-ninth of August, M DCCC LXXXIX Atlantic Monthly, Jan., 1890, vol. 65, p. 121, in "Over the Teacups."

Over the Teacups, 1890, pp. 43-44.

Poems, Riverside Edition, 1891.

\section{* To the Lady Opposite}

The Amateur, March 12, 1831, no. 16, p. 244.

To the Poets who only Read and Listen (At the Dinner of the $\Phi$. B. K. Society, June 25, 1885)

Atlantic Monthly, August, 1885, vol. 56, pp. 264-265.

Poems, Riverside Edition, 1891.

See "Two Anniversary After-Dinner Poems."

To the Portrait of a Gentleman

Poems, 1836.

To the Portrait of a Lady

Poems, 1836.

* To the Reverend S. F. Smith, D. D., Author of "My Country, ' $t$ is of Thee," on his eightieth birthday, Oct. 21, 1888

Poems of Home and Country, Rev. Samuel Francis Smith, 1895 , p. ix. (With a letter from Dr. Holmes to Mrs. Smith.)

While through the land the strains resound,

What added fame can love impart

To him who touched the string that found

Its echoes in a nation's heart?

No stormy ode, no fiery march,

His gentle memory shall prolong;

But on fair Freedom's climbing arch,

He shed the light of hallowed song.

Full many a poet's labored lines

A country's creeping waves will hide;

The verse a people's love enshrines

Stands like the rock that breasts the tide. 


\section{[ 84 ]}

Time wrecks the proudest piles we raise;

The towers, the domes, the temples fall;

The fortress ever crumbles and decays, -

One breath of song outlasts them all.

To the Teachers of America

Poems, Cambridge Edition, 1895.

Read at a dinner given by Mr. Houghton and other publishers, during a session in Boston of the National Educational Association, on Februury 23, 1893.

To John Greenleaf Whittier (On his Eightieth Birthday, 1887)

Before the Curfew, and Other Poems, 1888.

Toad-Stool, The

The Collegian, Feb., 1830, no. 1, pp. 23-24.

The Harbinger (1833), pp. 55-56.

Poems, 1836.

Toast to Wilkie Collins, A (Feb. 16, 1874)

Songs of Many Seasons, 1875.

Too Young for Love

Atlantic Monthly, July, 1890, vol. 66, p. 105, in "Over the Teacups."

Over the Teacups, 1890, p. 202.

Poems, Riverside Edition, 1891.

Treadmill Song, The (State Prison Melodies)

The Amateur, Aug. 7, 1830, no. 4, p. 59.

The Gleaner, or Selections in Prose and Poetry from the Periodical Press, 1830, pp. 125-126.

Poems, 1836, where the broader title is dropped, not to appear again.

* Triumph of Song, The

Atlantic Monthly, Sept., 1867, vol. 20, pp. 264-265, in "The Guardian Angel."

The Guardian Angel, 1867, pp. 302-303.

* Trumpet Song

Lyrics of Loyalty, 1864, pp. 150-152. 


\section{[85 ]}

This poem, which is quite unlike any other of its author's productions, has a refrain after each stanza:-

Ta ra! ta ta ta!

Beat drums and blow trumpets!

Trum, trum, tra ra ra ra!

Hurrah, boys, hurrah!

Two Anniversary After-Dinner Poems. I. Harvard Commencement, June 24, 1885, to J[ames] R[ussell] L[owell]. II. At the Dinner of the $\Phi$. B. K. Society, June 25, 1885; to the Poets who only Listen

Atlantic Monthly, Aug., 1885, vol. 56, pp. 263-265.

Two Armies, The

Atlantic Monthly, July, 1858, vol. 2, p. 245, in the "Autocrat." Autocrat of the Breakfast-Table, 1858, pp. 262-264.

Border Lines of Knowledge, etc., 1862, pp. 79-80.

Songs in Many Keys, 1862.

Two Poems to Harriet Beecher Stowe on her Seventieth Birthday (June 14, 1882)

See "At the Summit" and "The World's Homage."

* Two Shadows, The

The Amateur, Aug. 7, 1830, no. 4, p. 59.

The Gleaner, 1830, pp. 133-134.

The Harbinger, 1833, pp. 49-51.

\section{Two Streams, The}

Atlantic Monthly, June, 1859, vol. 3, p. 770, in the "Professor."

Professor at the Breakfast-Table, 1859, pp. 192-193.

Songs in Many Keys, 1862.

\section{Ugly Reflections}

[Buckingham's] New England Magazine, July, 1832, vol. 3, p. 21.

See "Daily Trials, by a Sensitive Man."

\section{Under the Violets}

Atlantic Monthly, Oct., 1859, vol.2,p.511, in the "Professor."

Professor at the Breakfast-Table, 1859, pp. 319-320.

Songs in Many Keys, 1862. 


\section{[86 ]}

Little Classics, Rossiter Johnson, editor, 1875, vol. vii, pp. 58-59.

Under the Washington Elm (April 27, 1861)

Chimes of Freedom and Union, 1861, p. 5.

Songs in Many Keys, 1862.

\section{Union and Liberty}

Atlantic Monthly, Dec., 1861, vol. 8, pp. 756-757.

Songs in Many Keys, 1862.

Printed on the programme for Commemoration Day at Harvard College, July 21, 1865.

\section{Unsatisfied}

Boston Daily Advertiser, May 10, 1876 (unsigned).

Poems, Household Edition, 1877.

At the Donaldson Sale, in 1899, an autograph letter of Dr. Holmes to the editors of the Advertiser, dated May 8, 1876, together with the original ms. of this poem, which he inclosed in the letter, requesting that it be printed anonymously, was sold for $\$ 16.00$.

Upham, Charles Wentworth, Jr., In Memory of

See "In Memory of," etc.

Urania, a Rhymed Lesson. Delivered before the Boston Mercantile Library Association, Oct. 14, 1846

Poems, 1849, pp. 207-240.

In the later collections, printed under the title, "A Rhymed Lesson," simply. For notes concerning the publication of extracts from "Urania," see "Boston Church Bells" and "A Sabbath in Boston."

\section{Verses for After-Dinner (Phi Beta Kappa, 1844)}

Poems, 1849.

See "Lines recited at the Cambridge Phi Beta Kappa Dinner."

Vestigia Quinque Retrorsum. An Academic Poem (Read at the Commencement Dinner of the Alumni of Harvard University, June 25, 1879, by one of the Class of 1829)

Atlantic Monthly, August, 1879, vol. 44, pp. 238-241.

The Iron Gate, and Other Poems, 1880. 


\section{[87 ]}

Additional Songs and Poems of the Class of 1829, 1881, pp. 186-192.

"Although not written for a class-meeting [it] cannot be omitted from a collection of poems of the Class of 1829."

\section{Vignettes}

Songs in Many Keys, 1862.

Under this group heading are included:

After a Lecture on Wordsworth.

After a Lecture on Moore.

After a Lecture on Keats.

After a Lecture on Shelley.

At the Close of a Course of Lectures.

The Hudson. After a Lecture at Albany.

The heading is retained in the Household Edition, but does not appear in the Riverside, Cambridge, or Cabinet Edition.

Vision, The

The Poet among the Hills (J. E. A. Smith), 1895, pp. 101105.

See "After a Lecture on Wordsworth" and "A Vision of the Housatonic."

* Vision of Life, A (Read at the graduating exercises of the Pittsfield Young Ladies' Institute in 1849)

The Poet among the Hills (J. E. A. Smith), 1895, pp. 111113.

Dr. Holmes made a short speech (given on pp. 110 and 111), after which he said:

"I will read you a few lines from a scrap of paper which, as you see, I have kept artfully concealed about my person."

\section{A VISION OF LIFE}

The well-known weakness of the rhyming race

Is to be ready in and out of place;

No bashful glow, no timid begging off,

No sudden hoarseness, no discordant cough

(Those coy excuses which your singers plead,

When faintly uttering: "No, I can't, indeed")

Impedes your rhymster in his prompt career.

Give him but hint; and won't the muse appear? 


\section{[88 ]}

So, without blushing, when they asked, I came -

I whom the plough-share, not the quill, should claim The rural nymphs that on my labors smile May mend my fence, but cannot mend my style.

The wingèd horse disdains my steady team, And teeming fancy must forget to dream.

I harrow fields and not the hearts of men;

Pigs, and not poems, claim my humble pen.

And then to enter on so new a stage,

With the iair critics of this captious age,

Might lead a sceptic to the rude surmise

That cits, turned rustics, are not overwise;

Or the bright verdure of the pastoral scene

Had changed my hue, and made me very green.

A few brief words that, fading as they fall, Like the green garlands of a festal hall,

May lend one glow, one breath of fragrance pour,

Ere swept ungathered from the silent floor.

Such is my offering for your festal day:

These sprigs of rhyme; this metrical bouquet.

$O$ my sweet sisters - let me steal the name

Nearest to love and most remote from blame -

How brief an hour of fellowship ensures

The heart's best homage at a shrine like yours.

As o'er your band our kindling glances fall,

It seems a life-time since I 've known you all!

Yet on each face, where youthful graces blend,

Our partial memory still revives a friend;

The forms once loved, the features once adored,

In her new picture nature has restored.

Those golden ringlets, rippling as they flow,

We wreathed with blossoms many years ago.

Seasons have wasted; but, remembered yet,

There gleams the lily through those braids of jet.

Cheeks that have faded, worn by slow decay,

Have caught new blushes from the morning's ray.

That simple ribbon, crossed upon the breast,

Wakes a poor heart that sobbed itself to rest;

Aye, thus she wore it; tell me not she died,

With that fair phantom floating by my side. 


\section{[ 89 ]}

'T is as of old: why ask the vision's name? All, to the white robe's folding, is the same; And there, unconscious of a hundred snows, On that white bosom burns the self-same rose.

$\mathrm{Oh}$, dear illusion, how thy magic power Works with two charms - a maiden and a flower!

Then blame me not if, lost in memory's dream, I cheat your hopes of some expansive theme. When the pale starlight fills the evening dim, A misty mantle folds our river's brin.

In those white wreaths, how oft the wanderer sees Half real shapes, the playthings of the breeze.

While every image in the darkening tide

Fades from its breast, unformed and undescried.

Thus, while I stand among your starry train,

My gathering fancies turn to mist again.

O'er time's dark wave aerial shadows play,

But all the living landscape melts away.

Vision of the Housatonic, A. Epilogue to a Lecture on Wordsworth

Knickerbocker Gallery (1855), pp. 23-26, with portrait.

See "After a Lecture on Wordsworth" and "The Vision."

\section{Vive la France!}

The Address of Mr. Everett and the Poem of Dr. Holmes at the Dinner given to $H$. H. Monseigneur the Prince Napoleon, Sept. 25, 1861, pp. 19-20.

Songs in Many Keys, 1862.

Voice of the Loyal North, A. National Fast, Jan. 4, 1861

(Written for the Class Meeting, Jan. 3, 1861)

Chimes of Freedom and Union, 1861, p. 44.

Songs in Many Keys, 1862.

Songs and Poems of the Class of 1829, 1868, pp. 59-61.

\section{Voiceless, The}

Atlantic Monthly, Oct., 1858, vol. 2, p. 630, in the "Autocrat." Autocrat of the Breakfast-Table (1858), pp. 355-356.

Songs in Many Keys, 1862.

Little Classics, Rossiter Johnson, editor, 1875, vol. xv, p. 229. 


\section{[90 ]}

"The Voiceless" is probably the "serious poem" to which Longfellow refers in his Journal as having been read by Holmes at a dinner of the Harvard Musical Association, Jan. 18, 1858.

Voyage of the Good Ship Union (Read at the Class Meeting, Jan., 1862)

Atlantic Monthly, March, 1862, vol. 9, pp. 398-400.

Poems, Blue and Gold Edition, 1862.

Songs and Poems of the Class of 1829, 1868, pp. 64-67.

The original ris. of this poem, 6 pp., small 4to, is in the Harvard College Library.

Waite, Josiah Kendall

See "H. C. M., H. S., J. K. W."

Ware, John and Robert, In Memory of

See "In Memory of J. W. R. W."

Warren, Joseph, M. D.

Boston Medical and Surgical Journal, June 17, 1875, vol. 92, p. 703.

Proceedings of the Bunker Hill Monument Association at the Annual Meeting, June 23, 1875, with the Oration of Hon. Charles Devens, Jr., and an account of the Centennial Celebration, June 17, 1875, p. 154.

Poems, Household Edition, 1877.

\section{Wasp, The, and the Hornet}

The Token and Atlantic Souvenir, 1833, p. 309.

The Boston Book, 1836, p. 118.

Poems, 1836.

* "We owe, alas! to woman's sin"

Iife and Letters of Oliver Wendell Holmes (Morse), 1896, vol. i, p. 202.

"In 1870 Miss Harriet Putnam (now Mrs. H. J. Hayden, of New York) sent him an apple 'stolen' from a tree which overhung the road in front of his old house, and he replied thus:"

We owe, alas! to woman's sin

The woes with which we grapple; -

To think that all our plagues came in

For one poor stolen apple! 


\section{[91 ]}

And still we love the darling thief

Whose rosy fingers stole it; -

Her weakness brought the world to grief,

Her smiles alone console it !

- I take the "stolen" fruit you leave, -

(Forgive me, Maid and Madam,)

It makes me dream that you are Eve,

And wish that I were Adam !

Webster, Daniel, Birthday of

See "Birthday of Daniel Webster."

Welcome to Chicago Commercial Club (Jan. 14, 1880)

The Iron Gate, and Other Poems, 1880.

Welcome to Dr. Benjamin Apthorp Gould, A (On his

Return from South America, after fifteen years devoted to cataloguing the stars of the Southern Hemisphere)

Addresses at the Complimentary Dinner to Dr. Benjamin Apthorp Gould, May 6, 1885, pp. 22-24.

Before the Curfew, and Other Poems, 1888.

Welcome to the Grand Duke Alexis. Music Hall, Dec. 9, 1871 (Sung to the Russian National Air by the Children of the Public Schools)

Programme of Exercises at the Musical Entertainment in

Honor of his Imperial Highness the Grand Duke Alexis;

4-page folder.

Songs of Many Seasons, 1875.

Mentioned, but not printed, in His Imperial Highness the Grand Duke Alexis in the United States, etc. (see page 8, supra). The date is given correctly in all collected editions of the poems prior to the Riverside, 1891, in which, and in the Cambridge and Cabinet Editions, it is printed December 6th.

Welcome to the Nations (Philadelphia, July 4, 1876)

The Centennial Liberty Bell, by Jos. S. Longshore, M. D., and Benjamin L. Knowles, Esq., 1876, p. 61.

His Royal Highness Prince Oscar [of Sweden] at the National Celebration of the Centennial Anniversary of American Independence, 1876, pp. 65-66.

Poems, Household Edition, 1877. 


\section{[92]}

What I Have Come For (Written for the Class Meeting, Jan. 9, 18\%3)

Songs of Many Seasons, 1875.

Additional Songs and Poems of the Class of 1899, 1868, pp. $155-156$.

What we all Think

Atlantic Monthly, April, 1858, vol. 1, pp. 743-744, in the "Autocrat."

Autocrat of the Breakfast-Table, 1858, pp. 168-170.

Songs in Many Keys, 1862.

Whittier, John Greenleaf

See "In Memory of John Greenleaf Whittier" and "To John Greenleaf Whittier."

* "Who that can pluck the flower will choose the weed"

Life and Letters of Oliver Wendell Holmes (Morse), 1896, vol. i, p. 232.

"A gentleman, famous for a generation as 'Tom Appleton,' . . . in a lottery at a fair drew an album, of which the alternate sheets bore prettily painted flowers and foliage. $\mathrm{He}$ passed it about to Longfellow, Emerson, Holmes, and the rest, asking each to select his page and write something upon it. . . . Holmes took a page bearing a cluster of wild autumnal leaves, and wrote:-

"Who that can pluck the flower will choose the weed, Leave the sweet rose and gather blooms less fair? And who my homely verse will stay to read, Straying enchanted through this bright parterre, When morning's herald lifts his purple bell And spring's young riolet wooes the wanderer's eye? Nay! let me seek the fallen leares that tell Of beggared winter's footstep drawing nigh; There shall my shred of song enshrouded lie, A leaf that dropped in memory's flowery dell; The breath of friendship stirred it, and it fell, Tinged with the loving hue of Autumn's fond farewell. "Boston, February 22, 1874." 


\section{[93 ]}

\section{Wind-Clouds and Star-Drifts, I-VII}

Atlantic Monthly, May-Nov., 1872, vol. 29, pp. 617-618, 742; vol. 30, pp. 107-110, 237-239, 362-363, 436-437, 522-523, in the "Poet."

The Poet at the Breakfast-Table, 1872, pp. 169-171, 201-203, 230-236, 270-274, 302-306, 334-338, 364-367.

Poems, Household Edition, 1877.

Wonderful One-Hoss Shay, The

See "The Deacon's Masterpiece."

\section{Woodlawn Cemetery}

Memory and Hope, Marian C. D. Silsbee, editor, 1851.

See "Poem for the Dedication of -the Pittsfield Cemetery."

Word of Promise, The (By supposition). An Hymn set forth to be sung by the Great Assembly at Newtown, Mo. 12. 1. 1636

Services at the Celebration of the Two Hundred and Fiftieth Anniversary of the Organization of the First Church in Cambridge, February 7-14, 1886, p. 22; preceded by remarks by Dr. Holmes, pp. 20-21.

Poems, Riverside Edition, 1891.

World's Homage, The. To Harriet Beecher Stowe on her Seventieth Birthday (June 14, 1882)

Before the Curfew, and Other Poems, 1888.

* "Yes, home is sweet! and yet we needs must sigh" (Read by Prof. H. P. Bowditch at the annual dinner of the Harvard Club of New York, Feb. 21, 1882)

Boston Medical and Surgical Journal, Feb. 23, 1882, vol. 106, p. 187; also Dec. 13, 1894 vol. 131, p. 586.

The sonnet was printed on slips for distribution at the dinner.

The second reference is to the account of the Holmes Memorial meeting of the Boston Medical Library Association, at which Dr. Bowditch again read the sonnet, having first told the circumstances under which it was written; he spoke of it as having never before been printed. It there has the title "Alma Mater." 


\section{[ 94 ]}

Yes, home is sweet! and yet we needs must sigh,

Restless until our longing souls have found

Some realm beyond the fireside's narrow bound

Where slippered ease and sleepy comfort lie, -

Some fair ideal form that cannot die

By age dismantled and by change uncrowned,

Else life creeps circling in the self-same round,

And the low ceiling hides the lofty sky.

$A h$, then to thee our truant hearts return,

Dear Mother, Alma, Casta - spotless, kind!

Thy sacred walls a larger home we find,

And still for thee thy wandering children yearn,

While with undying fires thine altars burn

Where all our holiest memories rest enshrined.

Youth (Written for the Thirty-First Anniversary of the Boston Young Men's Christian Union, May 31, 1882)

Poems, Cambridge Edition, 1895.

Not in Riverside Edition. The Boston Daily Advertiser of June 1, 1882, has an account of this anniversary celebration, with the poem in full, as well as the witty little speech with which Dr. Holmes prefaced it.

A copy of the poem, in Dr. Holmes's autograph, brought $\$ 16.00$ at Henkels's in 1898. 
II

\section{PROSE}

* Address at the Annual Meeting of the Boston Microscopical Society

Boston Medical and Surgical Journal, May 24, 1877, vol. 96, pp. 601-602.

* Address at the Inauguration of Cornelius C. Felton, LL. D., as President of Harvard College, July 19, 1860

Addresses at the Inauguration, etc., 1860 (pamphlet, 8vo), pp. 121-124, 132.

Dr. Holmes presided at the dinner after the inauguration, the account of which, with his speeches introducing the different speakers, is printed on pp. 121-149 of the pamphlet.

* Address before the Medical Library Association (Delivered at the formal presentation of Dr. Holmes's medical library, Jan. 29, 1889)

Boston Medical and Surgical Journal, Feb. 7, 1889, vol. 120, pp. 129-130.

* Address at the One Hundredth Anniversary of the Foundation of the Medical School of Harvard University, Oct. 17, 1883

The New Century and the New Building of the Harvard Medical School, 1884 (pamphlet, 8vo, illus.), pp. 3-35.

* After-Breakfast Talk, An

Atlantic Monthly, Jan., 1883, vol. 51, pp. 65-75.

* After Our Hundred Days

Atlantic Monthly, Jan., 1888, vol. 61, pp. 127-130.

* Agassiz's Natural History [Review]

Atlantic Monthly, Jan., 1858, vol. 1, pp. 320-333.

* Americanized European, The

Atlantic Monthly, Jan., 1875, vol. 35, pp. 75-86. 


\section{[96 ]}

* Amory, William, Memoir of

Proceedings of the Massachusetts Historical Society, June 13,

1889, 2d series, vol. 4, pp. 414-417.

See also p. 215 of the same volume.

* André, Major John, Life of [Review]

Atlantic Monthly, July, 1871, vol. 28, pp. 121-122.

* Appleton, Thomas Gold

Atlantic Monthly, June, 1884, vol. 53, pp. 848-850.

* Autocrat of the Breakfast-Table, The [No. I]

[Buckingham's] New England Magazine, Nov., 1831, and Feb., 1832, vol. 1, pp. 428-431, vol. 2, pp. 134-138.

These papers have been reprinted, but not in any authorized edition of Dr. Holmes's works, and are known to-day only as explaining the mysterious opening sentence of the real "Autocrat." They may be found in the Cornhill Booklet of Feb., 1901.

Autocrat of the Breakfast-Table, The

Atlantic Monthly, Nov., 1857, to Oct., 1858, vol. 1, pp. 48-57, 175-184, 312-320, 457-469, 614-625, 734-744, 871-883:

vol. 2, pp. 102-111, 234-245, 360-370, 496-506, 619-633.

As the poems scattered through the "Autocrat" have not been printed in any of the collected editions in the order in which they appear in that work, a list of them in that order is here given. Those which were printed in the Atlantic without titles are placed between brackets.

[Album Verses.]

Latter Day Warnings.

[A Parting Health - to J. L. Motley.] ${ }^{1}$

Spring has Come - Intra Muros.

A Good Time Going.

The Two Armies.

Musa.

The Deacon's Masterpiece.

Estivation.

Contentment.

[Prelude.]

1 This poem was first printed in the "Autocrat" when it appeared in book form. 


\section{[97 ]}

Parson Turell's Legacy.

The Voiceless.

[Sun and Shadow.]

[Prologue.]

[Ode for a Social Meeting.]

The Old Man Dreams.

The Chambered Nautilus.

Mare Rubrum.

What we All Think.

The Last Blossom.

The Living Temple.

* Autocrat, The, Gives a Breakfast to the Public

Atlantic Monthly, Dec., 1858, vol. 2, pp. 889-894.

Contains the poem "Avis." The original ms. of the article, 14 pp., 4to, brought $\$ 145.00$ at the Williamson Sale, 1904.

* Bartlett, The Late Dr. Elisha

Boston Medical and Surgical Journal, Aug. 14, 1865, vol. 53, pp. 49-52.

* Beecher, Henry Ward, Tribute to

The Beecher Memorial, Edward W. Bok, editor, 1887, pp. 1-3.

* Bigelow, Henry J., M. D., Memoir of

Proceedings of American Academy of Arts and Sciences, May 26, 1891, vol. 26, pp. 339-351.

* Bigelow, Dr. Jacob, Memoir of

Proceedings of American Academy of Arts and Sciences, May 27, 1879, vol. 14, pp. 333-342.

* Bigelow, Dr. Jacob, Remarks on

Proceedings of the Massachusetts Historical Society, Feb. 13, 1879 , vol. 17, pp. 40-44.

Border Lines of Knowledge in Some Provinces of Medical Science

[Abstract in] Boston Medical and Surgical Journal, Nov. 14, 1861, vol. 65, pp. 318-319, under the title "Dr. Holmes's Introductory Lecture."

Medical Essays, 1883. 


\section{[ 98 ]}

Bread and the Newspaper

Atlantic Monthly, Sept., 1861, vol. 8, pp. 346-352.

Soundings from the Atlantic, 1864, pp. 1-23.

Pages from an Old Volume of Life, 1883.

* Brewer, Gardner, Tribute to

In Memoriam. Died at Newport, Sept. 30, 1874, Gardner Brewer, pp. 8-12.

* Brief Expositions of Rational Medicine [Review]

Atlantic Monthly, Nov., 1858, vol. 2, pp. 763-764.

Cinders from the Ashes

Atlantic Monthly, Jan., 1869, vol. 23, pp. 115-123.

Pages from an Old Volume of Life, 1883.

* Clamms of Dentistry, The

Boston Medical and Surgical Journal, Feb. 29, 1872, n. s. vol. 9, pp. 134-141.

* Clarke, Edward Hammond, Memorial Sketch of

Visions: A Study of False Sight, by Edward H. Clarke, M. D., 1878, pp. xiii-xxii.

The same volume contains, on pp. vii-xiii, an introduction by Dr. Holmes.

* Clarke, James Freeman, Remarks on

Proceedings of the Massachusetts Historical Society, June 14, 1888, $2 \mathrm{~d}$ series, vol. 4, pp. 144-147.

Contagiousness of Puerperal Fever, The

New England Quarterly Journal of Medicine and Surgery, April, 1843, vol. 1, pp. 503-530.

Medical Essays, 1883.

See also "Puerperal Fever as a Private Pestilence."

Crime and Automatism

Atlantic Monthly, April, 1875, vol. 35, pp. 466-481.

Pages from an Old Volume of Life, 1883.

* Cry from the Study, A

Atlantic Monthly, Jan., 1886, vol. 57, pp. 91-98.

See "The New Portfolio," II. 
Currents and Counter-Currents in Medical Science

Medical Communications of the Massachusetts Medical Society, 1860, pp. 305-348. On pp. 345-348, under the heading "Notes," are certain passages omitted in delivery. ${ }^{1}$

Currents and Counter-Currents in Medical Science, with Other Addresses and Essays, 1861, pp. 1-50.

Medical Essays, 1883, pp. 173-208.

\section{* Dana, Richard H., Jr., Remarks on}

Proceedings of the Massachusetts Historical Society, Jan. 12, 1882, vol. 19, pp. 197-199.

* Dante, Remarks on (600th Anniversary of his birth)

Proceedings of the Massachusetts Historical Society, May 11, 1865, vol. 8, pp. 277-278.

* Davis, George T., Remarks on

Proceedings of the Massachusetts Historical Society, Oct. 11, 1877, vol. 15, pp. 310-311.

\section{* Debut, The}

[Buckingham's] New England Magazine, March, 1832, vol. 2, pp. 225-229. Signed O. W. H.

Contains the poem, "I cannot say if truth there be."

Dedicatory Address at the Opening of the New Building and Hall of the Boston Medical LiBrary Association (Read December 3, 1878)

* Boston Medical and Surgical Journal, Dec. 12, 1878, vol. 99, pp. 745-758.

See "Medical Libraries."

${ }^{1}$ In the Boston Medical and Surgical Journal, June 7, 1860, is the following note:-

"As the Address delivered by Dr. Holmes last week has been variously and erroneously reported in some of the public papers, the attention of our readers is directed to the following note on the subject from Dr. Holmes:

"Messrs. Editors, - I beg leave to say that I prepared an abstract of my address before the Massachusetts Medical Society for the Boston Journal, and disclaim all responsibility for opinions attributed to me in any other report of the Address.

“June 4th, 1860."

"Yours, very truly,

“O. W. Holmes. 


\section{[ 100 ]}

* Dental Cosmos, The. A Monthly Record of Dental Science [Review]

Boston Medical and Surgical Journal, March 11, 1869, n. s. vol. 3, pp. 99-102.

* Dr. Asa Gray's Botanical Series [Review]

Atlantic Monthly, Aug., 1858, vol. 2, pp. 383-384.

* Dr. Holmes at the Festival. "A reply to the charges which various evangelical papers have brought against a recent article of his in the Atlantic Monthly, that it is poisoning public opinion"

Quarterly Journal of the American Unitarian Association, July, 1859 , vol. 6 , pp. $355-362$.

The " article" referred to is not named, but the animadversions of the evangelical press were called forth by certain passages in the "Professor at the Breakfast-Table," notably in the installment which had recently appeared in the May number of the Atlantic Monthly.

* Doings of the Sunbeam

Atlantic Monthly, July, 1863, vol. 12, pp. 1-15.

Soundings from the Atlantic, 1864, pp. 228-281.

EDwards, Jonathan

International Review, July, 1880, pp. 1-28.

Sketches and Reminiscences of the Radical Club of Chestrut St., Boston, 1880, pp. 362-375.

Pages from an Old Volume of Life, 1883.

* Elliotson's Principles and Practice of Medicine [Review]

Boston Medical and Surgical Journal, Dec. 13, 1843, vol. 29, pp. 369-376.

Elsie Venner. Episode de la Vie Américaine. Par E.-D. Forgues

Revue des Deux Mondes, 15 Juin and 1 Juillet, 1861, tomes 33, pp. 930-963, and 34, pp. 67-100.

In this translation the story is very much abridged. It was published in book form in the same year. See infra, p. 178 . 


\section{[ 101 ]}

* Emerson, Ralph Waldo, Tribute to

Proceedings of the Massachusetts Historical Society, May 11, 1882, vol. 19, pp. 303-310.

Tributes to Longfellow and Emerson, 1882, pp. 39-50.

* Exotics [Review]

Atlantic Monthly, Sept., 1875, vol. 35, pp. 356-360.

* Facts and Traditions respecting the Existence of Indigenous Intermittent Fever in New England

Boylston Prize Dissertations for the Years 1836 and 1837 (1838), pp. 1-132.

Farewell Address to the Medical School of Harvard UNIVERSITY

Boston Medical and Surgical Journal, Dec. 7, 1882, vol. 107, pp. 529-534.

On page 546 are two letters from Dr. Holmes, dated Dec. 1 and 2, acknowledging gifts from his pupils.

See "Some of my Early Teachers."

* Great Instrument, The (A History of the Music Hall Organ)

Atlantic Monthly, Nov., 1863, vol. 12, pp. 637-647.

Soundings from the Atlantic, 1864, pp. 362-400.

Guardian Angel, The

Atlantic Monthly, Jan. to Dec., 1867, vol. 19, pp. 1-17, 129 143, 257-271, 385-401, 513-527, 641-654; vol. 20, pp. 1-15, 129-143, 257-274, 385-397, 513-527, 641-658. ${ }^{1}$

The poem "The Triumph of Song" occurs in the number for Sept., 1867, vol. 20, pp. 264-265.

\section{* Hawthorne}

Atlantic Monthly, July, 1864, vol. 14, pp. 98-101.

Pansie, by Nathaniel Hawthorne. His Last Literary Effort (London, Hotten), 1864, pp. 3-4.

In this very rare little volume Dr. Holmes's article is printed as an introduction.

'It is worth noting that "The Guardian Angel" occupied the place of honor at the head of the table of contents of the Atlantic throughout its course as a serial. 


\section{[102]}

* Hillard, George S., Remarks on

Proceedings of the Massachusetts Historical Society, Feb. 13, 1879, vol. 17, pp. 38-40.

* Holmes, Abiel

Duyckinck's Cyclopædia of American Literature, 1856, pp. 512-513.

* Holmes Estate, The

Harvard Book, 1875, vol. ii, pp. 424-426.

* Homœopathic Domestic Physician, The [Review]

Atlantic Monthly, Dec., 1857, vol. 1, pp. 250-252.

See "Some More Recent Views," etc.

* Homœopathy, Report of a Committee of the Massachusetts Medical Society on

See "Report of a Committee," etc.

Homceopathy, and its Kindred Delusions: Two Lectures delivered before the Boston Society for the Diffusion of Useful Knowledge, 1842

Currents and Counter-Currents in Medical Science, with Other Addresses and Essays, pp. 51-177 (Special Preface, pp. 53-55).

Medical Essays, 1883.

* How Far are the External Means of Exploring the Condition of the Internal Organs to be considered Useful and Important in Medical Practice? [Boylston Prize Dissertation for 1836]

Library of Practical Medicine, vol. vii, 1836, pp. 189-288. ${ }^{1}$

Boylston Prize Dissertations for the Years 1836 and 1837 (1838), pp. 245-371. ${ }^{2}$

Human Wheel, The, its Spokes and Felloes [with cuts]

Atlantic Monthly, May, 1863, vol. 11, pp. 567-580.

Soundings from the Atlantic, 1864, pp. 282-327.

See "The Physiology of Walking."

${ }_{1}$ This volume contains the other prize dissertations of that year, on the same subject, by Drs. Robert W. Haxall and Luther V. Bell.

${ }^{2}$ Here entitled, "On the Utility and Importance of Direct Exploration in Medical Practice." 
Inevitable Trial, The (ORATION DELIVERED BEFORE THE

City Authorities of Boston, July 4, 1863)

Soundings from the Atlantic, 1864.

Pages from an Old Volume of Life, 1883.

Intermittent Fever in New England

See "Facts and Traditions," etc.

\section{* Introduction}

Huguenots in the Nipmuck Country or Oxford [Mass.] prior to 1713 , by George F. Daniels, 1880, pp. x-xiv.

The Introduction is in the shape of a letter to Mr. Daniels.

\section{* Introduction to Horatian Echoes}

Horatian Echoes [Translation of the Odes of Horace], by John O. Sargent, 1893, pp. vii-ix.

"We began our literary life together. Hand in hand, like the Babes in the Wood, we ventured into the untried realm of letters: he, a college senior of twenty; I, a half-trained graduate of about the same age. Side by side our early productions appeared in the same periodicals."

See under "The Collegian," infra, p. 202.

* Introduction to Typical Elms, etc.

Typical Elms and Other Trees of Massachusetts, by Lorin L. Dame, 1890, pp. 7-10.

IrIs [From the "Professor at the Breakfast-Table"]

Little Classics, Rossiter Johnson, editor, 1875, vol. vii, pp. 8-82.

* Irving, Washington, Remarks on the Death of

Proceedings of the Massachusetts Historical Society, Dec. 15, 1859, vol. 4, pp. 418-422.

* Jackson, Dr. James. A Biographical Sketch

Boston Medical and Surgical Journal, Sept. 5, 1867, vol. 77, pp. 108-109.

The original manuscript of this sketch, $12 \mathrm{pp}$. , 4to, was presented by Dr. Holmes to the Boston Medical Library Association, May 1, 1876. 


\section{[ 104]}

* Jackson's (Dr. James) Letters to a Young Man (just entering upon practice) [Review]

Boston Medical and Surgical Journal, Oct. 4, 1855, vol. 53, pp. 197-206.

* Leyden in the Time of the Puritans, Remarks on (based on certain passages in Scaligerana)

Proceedings of the Massachusetts Historical Society, June 11, 1874 , vol. 13, pp. 315-317.

* Light of Asia, The [Review of Sir Edwin Arnold's poem] International Review, Oct., 1879, pp. 345-372.

* Livermore, George, Tribute to the Memory of

Proceedings of the Massachusetts Historical Society, Sept. 14,1865 , vol. 8, pp. 456-458.

Tribute of the Massachusetts Historical Society to the Memory of G. L., 1866, pp. 17-18.

\section{* Long and Interesting Friendship, A}

Cambridge [Mass.] Tribune, Feb. 20, 1892. Lowell Memorial Number.

* Longfellow, Henry W., Tribute to

Proceedings of the Massachusetts Historical Society, April 13,1882 , vol. 19, pp. 269-275.

Tributes to Longfellow and Emerson, 1882, pp. 13-22.

* Lotus Club, Address at Dinner of, April 15, 1883

A Brief History of the Lotus Club, by John Elderkin [c. 1895], pp. 61-64.

* Love (Review)

Atlantic Monthly, Sept., 1859, vol. 4, pp. 391-393.

Lowell, James Russell

See "A Long and Interesting Friendship."

* Lowell, Hon. John, Speech at Dinner given to, May 23, 1884 Reception and Dinner to Hon. John Lowell (pamphlet, 8vo), 1885, pp. 29-32.

"In respectfully proposing the health of his great-greatgrandmother, I am speaking of one whom few, if any, of you 


\section{[ 105 ]}

can remember. Yet her face is as familiar to me as that of any member of my own household. She looks upon me as I sit at my writing-table; she does not smile; she does not speak; even the green parrot on her hand has never opened his beak; but there she is, calm, unchanging, in her immortal youth, as when the untutored artist fixed her features on the canvas. To think that one little word from the lips of Dorothy Quincy, your greatgreat-grandmother, my great-great-grandmother, decided the question whether you and I should be here to-night, in fact whether we should be anywhere at all, or remain two bodiless dreams of nature! But it was Dorothy Quincy's yes or no to Edward Jackson which was to settle that important matter important to both of us, certainly - yes, your Honor; and I can say truly, as I look to you and remember your career, important to this and the whole American community. . . ."

Dr. H. then recited portions of "Dorothy $Q$.," changing " $I$ " to "we," "my" to "our," and, in one place, "me" to "we."

\section{* May and October}

[Buckingham's] New England Magazine, June, 1832, vol. 2, pp. 449-451.

\section{Mechanism in Thought and Morals}

Pages from an Old Volume of Life, 1883.

* Mechanism of Vital Actions (Review of Draper's Human Physiology, Statical and Dynamical; Carpenter's Mutual Relations of the Vital and Physical Forces; Grove's Correlation of Physical Forces; Metcalfe's Caloric: its Mechanical, Chemical, and Vital Agencies in the Phenomena of Nature)

North American Review, July, 1857, vol. 75, pp. 39-77.

Essays from the North American Review, Allen Thorndike Rice, editor, 1879, pp. 433-482.

* Medical Directions, written for Governor Winthrop by Ed. Stafford of London, in $\mathbf{1 6 4 3}$

Proceedings of the Massachusetts Historical Society, Feb. 13, 1862, vol. 5, pp. 379-399.

"Dr. Holmes communicated the following paper, commenting upon and illustrating a manuscript written by an eminent 


\section{$[106]$}

physician in England, and found in the collection of Winthrop Papers in the possession of the President of this Society."

* Medical Highways and By-ways

Boston Medical and Surgical Journal, June 1, 1882, vol. 106, pp. 505-513.

Medical Times and Gazette [London], Sept. 16, 1882, vol. 2 of that year, pp. 346-352.

Medical Libraries. Dedicatory Address at the Opening of the New Building and Hall of the Boston Medical Library Association

Boston Medical and Surgical Journal, Dec. 12, 1878, vol. 99, pp. 745-758.

Medical Essays, 1883.

See "Dedicatory Address," etc.

Medical Profession in Massachusetts, The

Lectures delivered in a Course before the Lowell Institute in Boston, etc., 1869, pp. 257-301.

Medical Essays, 1883.

* Medical School, The

Harvard Book, 1875, vol. i, pp. 239-251.

* Medicine in Boston. Additional Memoranda ${ }^{1}$

Memorial History of Boston, etc. (1881), vol. iv, pp. 549-570.

\section{* Microscopic Preparations}

Boston Medical and Surgical Journal, May 25, 1853, vol. 48, pp. 337-340.

* Minister Plenipotentiary, The [Henry Ward Beecher]

Atlantic Monthly, Jan., 1864, vol. 3, pp. 106-112.

\section{* Morse, Isaac E., Memorial Notice of}

Boston Daily Advertiser, March 5, 1866.

Mr. Morse was a member of the Class of '29, from the South; he served in the Confederate army. See a letter to his son in Morse's Life and Letters of O. W. H., vol. i, pp. 310-312.

${ }^{1}$ The main article on this subject was written by Dr. Samuel A. Green. 


\section{[ 107 ]}

* Mothers and Infants, Nurses and Nursing [Review]

Atlantic Monthly, May, 1859, vol. 3, p. 645.

* Motley, John Lothrop, Memoir of

Proceedings of the Massachusetts Historical Society, Dec. 12, 1878, vol. 16, pp. 404-473.

On p. 403 is the following note: "Dr. Holmes, through Mr. Winthrop, announced that the Memoir of John Lothrop Motley, which he had been appointed to prepare, would be published immediately, by Messrs. Houghton, Osgood \& Co., as had been agreed by the committee to whom their application for this privilege, made in June last, was referred. As the memoir had grown to a size greater than was expected at first, Dr. Holmes had revised the original draft, and had made numerous omissions so as to bring it within limits suited to publication in the Proceedings."

* Motley, John Lothrop, Tribute to

Proceedings of the Massachusetts Historical Society, June 14, 1877, vol. 15, pp. 292-297.

Tribute of the Massachusetts Historical Society to the Memory of Edmund Quincy and John Lothrop Motley, 1877, pp. 16-23.

My Hunt after " the Captain"

Atlantic Monthly, Dec., 1862, vol. 10, pp. 738-764.

Soundings from the Atlantic, 1864, pp. 24-123.

Pages from an Old Volume of Life, 1883.

Favorite Poems, and My Hunt after the Captain, 1884.

My Hunt after the Captain, and Other Papers, 1887.

Neuralgia, On the Nature and Treatment of

See "On the Nature," etc.

New Portfolio, The

Atlantic Monthly, Jan.-Dec., 1885, vol. 55, pp. 105-111, 248-258, 403-414, 523-534, 678-691, 721-733; vol. 56, pp. 1-13, 145-157, 353-364, 522-533, 694-706, 836-847.

Published under the title, "A Mortal Antipathy - First Opening of the New Portfolio."

In the number for May, 1885, is the poem "The Old Song," more familiarly known as "The Lyre of Anacreon." 


\section{[ 108 ]}

* New Portfolio, The, II

After the completion of the publication in serial form of the novel printed in the Atlantic under the above title (see above), Dr. Holmes contributed to the same magazine, in January, March, and July, 1886, three articles under the same general title, but having no connection with the novel or with one another. See "A Cry from the Study," "Two 'Occasional" Poems with an Introduction," and "A Prospective Visit."

\section{* New Stand for the Compound Microscope}

Proceedings of the Department of Microscopy of the Boston Society of Natural History, Aug., 1857.

Boston Medical and Surgical Journal, Dec. 10, 1857, vol. 52, pp. 376-380.

\section{* Old Books}

[Buckingham's] New England Magazine, Jan., 1832, vol. 2, pp. $46-49$.

* On the Nature and Treatment of Neuralgia

Boylston Prize Dissertations for the Years 1836 and 1837 (1838), pp. 133-243.

* On the Use of Direct Light in Microscopic Researches

Proceedings of the American Academy of Arts and Sciences, May 4, 1852, vol. 2, pp. 326-332.

* On the Utility and Importance of Direct Exploration in Medical Practice

Boylston Prize Dissertations for the Years 1836 and 1837 (1838), pp. 245-371.

See "How Far are the External Means of Exploring," etc.

* Oration before the New England Society of New YoRK, at their semi-centennial anniversary, 1855

Semi-Centennial Celebration of the New England Society in the City of New York, 1856, pp. 3-46.

The New England Society Orations. Addresses, Sermons and Poems delivered before the New England Society in the City of New York, 1820-1855; Cephas and Eveline Warner Brainerd, editors, 1901, vol. ii, pp. 271-302. 


\section{[ 109 ]}

In this volume the oration is introduced by the following note:

"This year the society returned to its early custom, and a poem formed a part of the program. . . The verses of Dr. Pierpont, though he was then over seventy years of age, would have been quoted with enthusiasm by the youngest and wildest abolitionist, while Dr. Holmes, his junior by thirty years, stood frankly for the most conservative element of the North. One sentiment of the orator in regard to slavery was met with a hiss, to which incident Dr. Pierpont referred at the dinner the following evening. 'I have prepared,' he said, 'some lines, should it ever occur again, which would run somewhat in the following fashion:

“' Our brother Holmes's gadfly was a thing

To Io known by its tormenting sting.

The noisome insect still is known by this,

But geese and serpents by their harmless hiss.'

“ Dr. Holmes, rising, instantly replied:

“ 'Well said, my trusty brother, bravely done;

Sit down, good neighbor, now I owe you one!" "

\section{* Our Battle-Laureate (H. H. Brownell)}

Atlantic Monthly, May, 1865, vol. 15, pp. 589-591.

\section{Our Hundred Days in Europe}

Atlantic Monthly, March to Oct., 1887, vol. 59, pp. 343-356. 533-545, 638-649, 832-842; vol. 60, pp. 116-126, 213-225, 289-299, 462-474.

A small part of the article entitled "The New Portfolio. A Prospective Visit," published in the Atlantic for July, 1886, was used as an introductory chapter when "Our Hundred Days" appeared in book form.

\section{* Our Progressive Independence}

Atlantic Monthly, April, 1864, vol. 13, pp. 497-512.

\section{Over the Teacups}

Atlantic Monthly, March, 1888, Jan. to Nov., 1890, vol. 61, pp. 323-328; vol. 65, pp. 111-121, 232-243, 402-412, 549$560,691-703,829-841$; vol. 66, pp. 92-105, 236-248, 387$400,535-547,660-671$. 


\section{[ 110 ]}

The poems occur in the Atlantic in this order:

To the Eleven Ladies, etc.

After the Curfew.

The Peau de Chagrin of State Street.

Cacoethes Scribendi.

The Rose and the Fern.

I Like You and I Love You.

La Maison d'Or.

Too Young for Love.

The Broomstick Train.

Tartarus.

At the Turn of the Road.

Invita Minerva.

* Parthenia [Review]

Atlantic Monthly, Feb., 1858, vol. 1, pp. 509-510.

Physiology of Versification, The. Harmonies of Organic and Animal Life

Boston Medical and Surgical Journal, Jan. 7, 1875, vol. 92, pp. 6-9.

Pages from an Old Volume of Life, 1883.

Physiology of Walking, The

Pages from an Old Volume of Life, 1883.

My Hunt after the Captain, and Other Papers, 1888.

See "The Human Wheel, its Spokes and Felloes."

* Pillow-Smoothing Authors

Atlantic Monthly, April, 1883, vol. 51, pp. 457-464.

Poet at the Breakfast-Table, The

Atlantic Monthly, Jan. to Dec., 1872, vol. 29, pp. 90-104, 224$236,338-349,485-496,606-618,731-742$; vol. 30 , pp. 98110, 225-239, 352-363, 426-437, 513-526, 720-734.

The poems occur in the Atlantic in this order:

Homesick in Heaven.

Fantasia.

Aunt Tabitha.

$\mathrm{J}$ [oseph] A[ngier].

Wind Clouds and Star-Drifts, I to VII.

Epilogue to the Breakfast-Table Series. 


\section{[111 ]}

* Poet, to the Children, The (Letter to the School Children of Cincinnati, on their celebration of his 71st Birthday) Holmes Leaflets, 1881, p. 11.

* Position and Prospects of the Medical Student, THE

Currents and Counter-Currents in Medical Science, with Other Addresses and Essays, 1861.

Professor at the Breakfast-Table, The

Atlantic Monthly, Jan. to Dec., 1859, vol. 3, pp. 85-96, 232$241,350-361,492-503,609-620,760-770$; vol. 4 , pp. 119128, 232-243, 369-379, 500-511, 622-634, 751-766.

The poems occur in the Atlantic in this order:

De Sauty.

The Boys.

The Opening of the Piano.

[At a Birthday Festival - To J. R. Lowell.] ${ }^{1}$

The Crooked Footpath.

A Mother's Secret.

Robinson of Leyden.

Saint Anthony the Reformer - His Temptation.

Midsummer.

Iris, Her Book.

Under the Violets.

Hymn of Trust.

A Sun-Day Hymn.

The "Story of Iris," which is told piecemeal, so to speak, in the "Professor," has been put together and published separately. See p. 171, infra.

Professor's Story, The

Atlantic Monthly, Jan., 1860, to April, 1861, vol. 5, pp. 88-99, 222-235, 347-357, 470-486, 602-614, 735-746; vol. 6, pp. 95-105, 215-227, 362-373, 482-492, 613-631, 729-739; vol. 7, pp. 75-85, 214-226, 272-283, 395-415.

Published in book form, at first in two volumes, in 1861, under the title of "Elsie Venner."

1 Without title in the Atlantic and in the various editions of the "Professor." 


\section{[ 112 ]}

* Prospective Visit, A

Atlantic Monthly, July, 1886, vol. 58, pp. 1-16.

A small portion of this article - roughly speaking, the first and last three pages - was afterward printed as an introductory chapter to Our Hundred Days in Europe, 1887; there are some changes, however, even in those passages which were used in the volume.

See "The New Portfolio," II.

* Public Parks, Speech on the subject of

Parks for the People (8vo pamphlet), 1876, pp. 20-25.

Puerperal Fever as a Private Pestilence

Currents and Counter-Currents in Medical Science, with Other Addresses and Essays, 1861.

This essay was printed originally (1843) under the title "The Contagiousness of Puerperal Fever," and that title was restored when it was published in Medical Essays, 1883.

Pulpit and the Pew, The

North American Review, Feb., 1881, vol. 132, pp. 117-138.

Pages from an Old Volume of Life, 1883.

\section{* Reflex Vision}

Proceedings of the American Academy of Arts and Sciences, Feb. 14, 1860, vol. 4, pp. 373-375.

* Reply of Dr. Holmes on the Presentation of the Portrait of Dr. J. B. S. Jackson to the Boston Medical Library Association [May 23, 1881]

Boston Medical and Surgical Journal, June 16, 1881, vol. 104, pp. 560-561.

* Report of a Committee of the Massachusetts Medical Society on Homœopathy

Boston Medical and Surgical Journal, March 5, 1851, vol. 44, pp. 97-100.

The report is signed by George Hayward, John B. S. Jackson, and Dr. Holmes. 


\section{[ 113 ]}

Report of the Committee on the Plowing-Match at the Cattle-Show of the Berkshire Agricultural Society, 1849

The Poet among the Hills (J. E. A. Smith), 1895, pp. 129-133; closing with the poem, "The Ploughman" (here spelled Plowman).

Poems, Cambridge Edition, 1895, pp. 339-340, Appendix.

* Response of Dr. Holmes at the banquet to his honour by the Liverpool Philomathic Society, 1886

Response to the Toast "The President of the United States," together with the response of the Guest of the Evening, Dr. Oliver Wendell Holmes, at the banquet to his honour by the Liverpool Philomathic Society, August 20th, 1886, pp. 11-13. ${ }^{1}$

Scholastic and Bedside Teaching. An Introductory Lecture delivered before the Medical Class of Harvard University, Nov. 6, 1867

Medical Essays, 1883.

See "Teaching from the Chair and at the Bedside."

* Seasons, The. By the "Autocrat of the Breakfast-Table"

The Atlantic Almanac, 1868, edited by Oliver Wendell Holmes and Donald G. Mitchell, pp. 2-13.

* Sex in Education [Review]

Atlantic Monthly, Dec., 1873, vol. 32, pp. 737-740.

* Some More Recent Views on Homœopathy. A Notice of the Homœopathic Domestic Physician

Atlantic Monthly, Dec., 1857, vol. 1, pp. 250-252; under the title "The Homœopathic Domestic Physician."

Currents and Counter-Currents in Medical Science, with Other Addresses and Essays, 1861.

1 This is a 12mo pamphlet of 16 unnumbered pages, with a decorative front cover; the collation is as follows: 1-2, blank; 3, dedication, signed H[arold] M[arsh] S[ewall], and dated Liverpool, England, Sept. 1, 1866. "For Private Circulation;" 4-6, blank; 7-9, response by Harold Marsh Sewall to the above-named toast; 10, blank; 11-13, response of Dr. Holmes to the toast to himself; 14, blank; 15, verse; 16 , blank. 


\section{[114 ]}

Some of my Early Teachers. Dr. Holmes's Farewell Address to the Medical School

Medical Essays, 1883.

See "Farewell Address," etc.

* Speech at the Annual Dinner of the Massachusetts Medical Society, May, 1856

Speeches of Drs. Thompson, James Jackson, John Homans, O. W. Holmes, S. Durkee, and H. W. Williams, in response to sentiments offered at the Annual Dinner, etc., 1856, pp. 9-11.

* Speech at the Dinner of the Alumni of Harvard College, Nov., 1886

Record of the Commemoration, November fifth to eighth, 1886, etc. (1887), pp. 302-304.

* Speech at the First Dinner of the Phillips Academy Alumni Association, March 24, 1886

Speeches at the First Dinner, etc., 1886, pp. 21-26. "Bill and Joe" is introduced on pp. 23-24.

"Brethren of the Alumn: I had a call this morning from that most formidable of visitors, the reporter, who asked me for the poem I was going to read to-night, which poem was a fiction of his own powerful imagination. It is sixty-one years since I read my first verses at Phillips Academy. It is eight years since I read a long poem on the celebration of the one hundredth anniversary of the institution. . . .

"I am going to read you a poem, written for another occasion, but surely it never could be read more appropriately than it is now. As the gray heads come together the young ones will sympathize with them, but the gray heads as they meet their old companions feel that all their differences of situation, of history, of condition, are abolished, and this poem embodies that feeling. Will you listen to 'Bill and Joe,' to two gray-headed old men who meet, one, perhaps, high in position, the other humble, struggling to forget all their differences, and strip off everything, and call each other by the old names, the old short names? There are not more than half a dozen people now living, out of my own family, that call me by my first name. Queen Victoria said, "There is nobody left to call me "Vic."' It is a dreadful loss 
when you lose your 'Bill,' and become the Honorable So-andSo. ... .

"I was subjected to the severest castigation known, I believe, in the annals of punishment in the institution, such as made a sensation among all the delicate females of the vicinity, and caused young men to utter violent threats, and was, in fact, almost the occasion of a riot. It was an unfortunate display of temper on the part of one of the instructors. [Laughter and applause.] Forty years afterward I heard a knock at my study door, and an old, bending man came in and looked me in the eyes, and I in his. I knew what he came for. [Laughter.] He knew, too well, what he came for. [Renewed laughter.] But we made the usual meteorological remarks [great laughter] and we sat down, I with a cold and calm hospitality; he, evidently, laboring under some inward embarrassment. Presently it came out, the confession and the pardon came out, and after that we were, though separated - and he is now dead or I would not mention it - we were good friends, so far as friendship could base itself upon such a foundation." [Great laughter.] "

* Speech at the Graduating Exercises of the Pittsfield Young Ladies' Institute, 1849

The Poet among the Hills (J. E. A. Smith), 1895, pp. 110-111; concluding with the previously unpublished poem, "A Vision of Life."

* Speech at the "Jubilee Dinner" at Pittsfield, Aug. 23, 1844

The Poet among the Hills (J. E. A. Smith), 1895, pp. 65-66; followed by the poem, "Come back to your mother, ye children, for shame." ("Lines recited at the Berkshire Festival.")

* Stereoscope and the Stereograph, The

Atlantic Monthly, June, 1859, vol. 3, pp. 738-748.

Soundings from the Atlantic, 1864, pp. 124-165.

* Storer, Dr. David Humphrey, Tribute to

Memorial Meeting of the Boston Society of Natural History, Dec. 16, 1891, pp. 353-354. 


\section{[ 116 ]}

* Sun-Painting and Sun-Sculpture

Atlantic Monthly, July, 1861, vol. 8, pp. 13-29.

Soundings from the Atlantic, 1864, pp. 166-227.

Talk concerning the Human Body and its Management.

By the Professor at the Breakfast-Table

The Atlantic Almanac, 1869, edited by Donald G. Mitchell.

pp. 47-58.

Pages from an Old Volume of Life, 1883.

* Taylor, Bayard, Tribute to the Memory of

See Appendix, p. 310, infra.

* Two "Occasional " Poems with an Introduction

Atlantic Monthly, March, 1886, vol. 57, pp. 369-374.

See "The New Portfolio," II. The poems are "The Old

Tune. Thirty-Sixth Variation" and "To Frederick Henry Hedge."

* Undergraduate, The [Review]

Atlantic Monthly, March, 1860, vol. 5, pp. 382-383.

Valedictory Address to the Graduating Class of Bellevue Hospital College, March 2, 1871

New York Medical Journal, April, 1871, vol. 13, pp. 420-440.

See "The Young Practitioner."

* Valedictory Address to the Medical Graduates of Harvard University, 1858

Boston Medical and Surgical Journal, March 25,1858, vol.58, pp. 149-159.

Currents and Counter-Currents in Medical Science, with Other Addresses and Essays, 1861.

* Visit to the Asylum for Aged and Decayed Punsters, A

Atlantic Monthly, Jan., 1861, vol. 7, pp. 113-117.

Soundings from the Atlantic, 1864, pp. 348-361.

* Visit to the Autocrat's Landlady, A

Atlantic Monthly, Nov., 1858, vol. 2, pp. 738-744.

Soundings from the Atlantic, 1864, pp. 328-347.

Contains the poem "The Old Man of the Sea - A Nightmare Dream by Daylight." See p. 52, supra. 


\section{[ 117 ]}

* Warren, Dr. John Collins, Tribute to

The Life of John Collins Warren, M.D., by Edward Warren, 1860 , vol. ii, pp. 296-302.

* Warren, Dr. J. Mason, Remarks on the Character of

Boston Medical and Surgical Journal, Aug. 22, 1867, vol. 77, pp. 66-68.

\section{* Week of Frailty, A}

[Buckingham's] New England Magazine, Oct., 1831, vol. 1, pp. 316-320.

Signed O. W. H. Contains two poems without title, one of which has had its place in all collected editions under the title "L'Inconnue;" the other, which has never been reprinted, begins: "Hast thou a look for me, love?"

* Wormwood Cordial of History, The

Atlantic Monthly, Oct., 1861, vol. 8, pp. 507-512.

* Wyman, Professor Jeffries

Atlantic Monthly, Nov., 1874, vol. 34, pp. 611-623.

Proceedings of the Massachusetts Historical Society, April 15, 1875, vol. 14, pp. 4-24.

A copy of this last-named pamphlet (which contains also the poem "Grandmother's Story of Bunker Hill Battle"), with an autograph letter of Dr. Holmes inserted, was sold at the Arnold Sale, 1901, for $\$ 10.00$; another at the Pyser Sale, 1906, for $\$ 3.00$.

Young Practitioner, The. A Valedictory Address delivered to the Graduating Class of the Bellevue Hospital College, March 2, 1871

Medical Essays, 1883. 


\section{CHRONOLOGICAL LIST OF SINGLE PUBLICATIONS \\ I}

\section{POETRY}

The first entry in this list is placed here, although it contains poems by other hands than Dr. Holmes's, because it may properly be regarded as the first collected edition of his poems. In like manner the various issues of the Songs of the Class of '29 are included in this division; although they contain the work of several other members of the Class, they are generally, and not unnaturally, regarded as special collections of Dr. Holmes's poems. The magazines in which his earliest productions were printed are placed, for convenience, if not most appropriately, under the heading Selections and Compilations.

\section{THE HARBINGER}

The Harbinger: | A | May-Gift. | Boston: | Carter, Hendee and Co. ! MDCCCXxxirr. 8vo, pp. vi, 96.

Dedicated " To the Ladies who have so kindly aided the New England Institution for the Blind."

A collection of poems divided into three parts, viz.: Part I, by Park Benjamin, pp. 1-30; Part II, by Oliver Wendell Holmes, pp. 31-61; Part III, by John O. Sargent, pp. 63-96. The authors' names do not appear.

Part II contains: -

The Dying Seneca.

* The Departure.

The Last Leaf.

The Ballad of the Oysterman.

From a Bachelor's Private Journal.

Domestic Thoughts. 
Lines by a Very Interesting Young Man.

My Aunt.

The Dilemma.

“Is thy Name Mary, Maiden Fair" (L'Inconnue).

* The Two Shadows.

Thoughts in Dejection (The Poet's Lot).

To an Insect.

The Toadstool.

Evening.

Moonshine.

Stanzas.

Of these seventeen poems, all save the first - "The Dying Seneca" - had previously appeared in the Collegian, the Amateur, or Buckingham's New England Magazine.

\section{POFMS, 1836}

Poems. | By | Oliver Wendell Holmes. | Boston: | Otis, Broaders, and Company. | M DCCC Xxxvi. $8 \mathrm{vo}, \mathrm{pp}$. xvi, 164. The collation is as follows: i, half-title; ii, blank; iii, title; iv, copyright, and imprint (Cambridge: Printed by Folsom, Wells, and Thurston); v-xii, preface; xiii-xiv, contents; xv, half-title ("Poetry: a Metrical Essay"); xvi, blank; 1, dedication (To Charles Wentworth Upham the following Metrical Essay is affectionately inscribed); 2, blank; 3-39, "Poetry;" 40, blank; 41-44, notes to "Poetry;" 45, half-title (Lyrics); 46, blank; 47-163, lyrics; 164, colophon (Cambridge: Folsom, Wells, and Thurston).

Some copies have on the title-page, just above the date, the additional imprint: "New York:| George Dearborn and Company."

On pp. 16-20 is printed (without separate title) "The Cambridge Churchyard," and on pp. 24-25 (likewise 


\section{[ 120$]$}

without title), "Old Ironsides." In the contents, these familiar titles appear as sub-titles under "Poetry."

The Preface is as follows:-

As the poem which stands at the head of this collection was received kindly enough to warrant its publication, I have availed myself of this occasion as an apology for offering a little book to the public. Among the poems which it contains are several, which the wishes of others rather than my own have led me to admic. Besides, having written comparatively little, and nothing of late years, until within a few months, I could ill afford to be over nice in my selection, unless I were willing to reduce my volume to dimensions odious alike to the self-love of authors and the cupidity of booksellers. If the good-natured reader, then, should find some pages a little overdull, or overextravagant, let him take it for granted, that they were reluctantly admitted by the author in consideration of the exigencies of the publisher.

The first poem in the collection being somewhat discursive, I will point out, in a few words, its scope and connexion. Its object is to express some general truths on the sources and the machinery of Poetry; to sketch some changes which may be supposed to have taken place in its history, constituting four grand eras; and to point out some less obvious manifestations of the poetic principle. The stages assigned to the progress of poetry are as follow:-

I. The period of Pastoral and Descriptive Poetry; which allowed a digression upon Rome, and the introduction of a descriptive lyric. ${ }^{1}$

II. The period of Martial Poetry. At the close of this division are some remarks on our want of a national song, and an attempt is made to enliven the poem by introducing a lyric ${ }^{2}$ which deals in martial images and language, although written only for an occasional purpose.

III. The Epic or Historic period of Poetry. Under this division of the subject, the supposed necessity of an American "Iliad" was naturally enough touched upon.

IV. The period of Dramatic Poetry, or that which analyzes, and traces from their origin, the passions excited by certain combinations of circumstances. As this seemed the highest

1 "The Cambridge Churchyard." 2 "Old Ironsides." 


\section{[121 ]}

reach of poetical art, so it constitutes the last of my supposed epochs.

The remarks contained in the last division relate to some of the different forms in which poetry has manifested itself, and to a pseudo-poetical race of invalids, whose melancholic notions are due, much oftener than is supposed, to the existence of pulmonary disease, frequently attributed to the morbid state of mind of which it is principally the cause. The allusions introduced at the close will carry their own explanation to all for whom they were intended. I have thus given a general analysis of a poem which, being written for public delivery, required more variety than is commonly demanded in metrical essays.

The shorter pieces are arranged mainly with reference to the dignity of their subjects. A few remarks with regard to a species of writing in which the author has occasionally indulged, are offered to the consideration of those who are disposed to criticise rigorously; without the intention, however, of justifying all or any of the attempts at comic poetry, if they are bad specimens of their kind.

The extravagant is often condemned as unnatural; as if a tendency of the mind, shown in all ages and forms, had not its foundation in nature. A series of hyperbolical images is considered beneath criticism by the same judges who would write treatises upon the sculptured satyrs and painted arabesques of antiquity, which are only hyperbole in stone and colors. As material objects in different lights repeat themselves in shadows variously elongated, contracted, or exaggerated, so our solid and sober thoughts caricature themselves in fantastic shapes inseparable from their originals, and having a unity in their extravagance, which proves them to have retained their proportion in certain respects, however differing in outline from their prototypes. To illustrate this by an example. Our idea of a certain great nation, an idea founded in substantial notions of its geography, its statistics, its history, in one aspect of the mind stretches into the sublime in the image of Britannia and in another dilates into the sub-ridiculous in the person of John Bull. Both these personifications partially represent their object; both are useful and philosophical. And I am not afraid to say to the declaimers upon dignity of composition, that a metrical arabesque of a storm or a summer, if its images. 
though hyperbolical, are conceivable, and consistent with each other, is a perfectly healthy and natural exercise of the im- agination, and not, as some might think, a voluntary degradation of its office. I argue, as I said before, for a principle, and not for my own attempt at its illustration.

I had the intention of pointing out some accidental plagiarisms, or coincidences as they might be more mildly called, discovered principally by myself after the composition of the passages where they occur; but as they are, so far as I know, both innocent and insignificant, and as I have sometimes had literary pickpockets at my own skirts, I will leave them, like the apples of Atalanta, as an encouragement to sagacious critics, should any such follow my footsteps.

I have come before the public like an actor who returns to fold his robes and make his bow to the audience. Already engaged in other duties, it has been with some effort, that I have found time to adjust my own mantle; and I now willingly retire to more quiet labors, which, if less exciting, are more certain to be acknowledged as useful and received with gratitude; thankful that, not having staked all my hopes upon a single throw, I can sleep quietly after closing the last leaf of my little volume.

O. W. H.

Boston, Massachusetts, 1 Norember, 1836.

Contents:-

Poetry: a Metrical Essay.

The Last Reader.

Our Yankee Girls.

La Grisette.

An Evening Thought.

A Souvenir.

"Qui Vive."

The Wasp and the Hornet.

From a Bachelor's Private Journal.

Stanzas.

The Philosopher to his Love.

L'Inconnue.

The Star and the Water Lily.

Illustration of a Picture.

The Dying Seneca.

A Portrait.

A Roman Aqueduct. 


\section{[ 123 ]}

The Last Prophecy of Cassandra.

To a Caged Lion.

To my Companions.

The Last Leaf.

To a Blank Sheet of Paper.

To an Insect.

The Dilemma.

My Aunt.

The Toadstool.

The Meeting of the Dryads.

The Mysterious Visiter. ${ }^{1}$

The Spectre Pig.

Lines by a Clerk.

Reflections of a Proud Pedestrian.

The Poet's Lot.

Daily Trials.

Evening. By a Tailor.

The Dorchester Giant.

To the Portrait of "A Gentleman."

To the Portrait of "A Lady."

The Comet.

A Noontide Lyric.

The Ballad of the Oysterman.

The Music-Grinders.

The Treadmill Song.

The September Gale.

The Height of the Ridiculous.

The Hot Season.

POEMS, 1846

Poems. | By | Oliver Wendell Holmes. | London:| O. Rich \& Sons, 12, Red Lion Square. MDCCCXLVI.

12mo, pp. xxiv, 176. Collation is as follows: i, half-title; ii, blank; iii, title; iv, imprint (London: Bradbury and Evans, Printers, Whitefriars); v, Note by the English Pub-

${ }^{1}$ The word is so spelled in all impressions of the edition of 1849, after which it was changed to Visitor. 


\section{[ 124$]$}

lisher; ${ }^{1}$ vi, blank; vii-xii, preface to the first American edition; xiii-xv, contents; xvi, blank; xvii-xx, Memoir of the Author; ${ }^{2}$ xxi, half-title ("Poetry: a Metrical Essay"); xxii, blank; xxiii, dedication; 1-34, "Poetry;" 35-38, notes on "Poetry;" 39, half-title (Miscellaneous Poems); 40, blank; 41-175, poems; 176, colophon (London: Bradbury and Evans, Printers, Whitefriars).

The first English edition of the Poems, although the title-page of the Routledge edition of 1852 tells a different story, which Dr. Holmes's remarks regarding the present edition in his preface to that of 1849 (infra, p. 126) may partly explain. The poems contained in the edition of 1836 are reprinted without change, except that "To my Companions" precedes "To a Caged Lion." The volume contains these additional poems:-

Lines recited at the Cambridge Phi Beta Kappa Society's Dinner [1844].

Terpsichore.

The Parting Word.

Lines recited at the Berkshire Festival.

Song, written for the Annual Dinner of the New York Mercantile Library Association.

Departed Days.

The Steamboat.

Song, written for the Dinner given to Charles Dickens, by the Young Men of Boston.

The Only Daughter.

1 “'Those poems which follow 'The Hot Season,' on page 141, are here collected for the first time from magazines and other sources, available to the English Editor."

2 From Griswold's Poets and Poetry of America. 


\section{URANIA: A RHYMED LESSON}

[Ornament] Urania: | a Rhymed Lesson. | By Oliver Wendell Holmes. | Pronounced before the Mercantile Library Association, | October 14, 1846.|Boston:|William D. Ticknor \& Company. | MDCCCXLvI.

Pamphlet, 8vo, pp. 32, viz.: 1, title; 2, copyright, and imprint (Boston: Printed by Freeman and Bolles, Devonshire Street); 3-31, poem; 32, notes.

A second edition was published in the same year, identical with the above, except that the words "Second Edition" are added on the title-page, below the date.

In a letter to J. R. Lowell, dated Nov. 29, 1846, printed in Morse's Life and Letters, vol. i, 295-303, Dr. Holmes answers certain strictures of Lowell, and discusses the poem and his own views as reflected therein.

\section{POEMS, 1849}

Poems. | By | Oliver Wendell Holmes. | New and Enlarged Edition. | [Cut] Boston:|William D. Ticknor \& Company. | M DCCC XLIX. | [c. 1848.] 8vo, pp. xii, 272; numerous vignettes and tail-pieces. The collation is as follows: i, halftitle; ii, blank; iii, title; iv, copyright, and imprint (Boston: Thurston, Torry and Emerson, 31 Devonshire Street); v-vi, From a Letter of the Author to the Publishers; vii-x, contents; xi, dedication of "Poetry;" xii, blank; 1-35, “Poetry;” 36, blank; 37-40, notes on "Poetry;" 41, half-title (Lyrics); 42, cut; 43-160, lyrics; 161, half-title (Poems added since the First Edition); 162, cut; 


\section{[ 126 ]}

163-192, poems; 193-226, "Urania, a Rhymed Lesson;" 227-228, notes on "Urania;" 229272, poems.

The extract "from a letter of the Author," printed as preface to this somewhat rare volume, reads as follows:

As these productions are to be given to the public again at your particular request, I must trust that you will make all proper explanations. I need hardly remind you that a part of them appeared in a volume published about a dozen years ago; that when this volume had been some time out of print, another edition was printed, at your suggestion, in London, but I suppose sold principally in this country; and that the present edition is published to please you rather than to gratify myself. You will, therefore, take the entire responsibility of the second and third appearances, except so far as my consent involved me in the transaction.

Let me remark, also, that it was only to suit your wishes that several copies of verses, which sound very much like school exercises, were allowed to remain unexpunged. If any body takes the trouble to attack them, you may say that they belong to the department of "Early" or "Juvenile" Poems, and should be so ticketed. But stand up for the new verses, especially those added in this edition. Say that those two names, "Terpsichore" and "Urania," may perhaps sound a little fantastic, but were merely intended as suggestive titles, and fall back upon Herodotus. Say that many of the lesser poems were written for meetings more or less convivial, and must of course show something like the fire-work frames on the morning of July 5 th. If any objection is made to that bacchanalian song, say that the author entirely recedes from several of the sentiments contained in it, especially that about strong drink being a national want. But ask, if a few classical reminiscences at a banquet may not be quite as like to keep out something worse, as to stand in the way of something better.

If any thing pleasant should be said about the "new edition," you may snip it out of the paper and save it for me. If contrary opinions are expressed, be so good as not to mark with brackets, carefully envelop, and send to me, as is the custom with many friends. 


\section{[ 127 ]}

I have looked over the proof-sheets pretty accurately, and arranged the poems in something like order. The first one hundred and fifty-eight pages contain all that were printed in the edition of 1837 [1836]; the next thirty-two pages were added in that of 1846; the remaining ones are now added.

You can take this note of mine as the basis of some kind of programme or advertisement; but that "Preface" and "Biography" " made rather too heavy a portico for so slight a structure as the volume they introduced, and had better be abstracted.

The "Poems added since the First Edition" include all of those added in the edition of 1846 except "The Only Daughter," but arranged in a different order; also the following, which had not previously been collected:

Urania: a Rhymed Lesson (which had already appeared as a separate publication).

The Pilgrim's Vision.

A Modest Request.

Nux Postcœnatica.

On Lending a Punch-Bowl.

The Stethoscope Song.

Extracts from a Medical Poem.

A Song of Other Days.

A Sentiment ("The Pledge of Friendship," etc.).

The Same. Boston:| Ticknor, Reed \& Fields. | MDCCCXLIX. $\mid$ [c. 1848.]

8vo, pp. xii, 286.

This second issue of the Poems of 1849 differs from that bearing the imprint of W. D. Ticknor \& Co. in the following respects:-

The imprint on p. iv (back of title) is, "Stereotyped by George A. Curtis; New England Type and Stereotype Foundery [sic], Boston. Printed by Thurston, Torry \& Co., 31 Devonshire Street." The prefatory matter on pp. v-vi is headed "The Author to the Publisher," and is entirely different from the corresponding matter in the earlier issue. It reads as follows:-

1 [Referring to the London edition of 1846.] 


\section{[128]}

I thank you for the pains you have taken to bring together the poems now added to this collection; one of them having been accidentally omitted, and the existence of the others forgotten. So many productions which bear the plain marks of immaturity and inexperience have been allowed to remain, because they were in the earlier editions, that a few occasional and careless stanzas may be added to their company without any apology. I have no doubt you are right in thinking that there is no harm in allowing a few crudities to keep their place among the rest; for, as you suggest, the readers of a book are of various ages and tastes, and what sounds altogether schoolboylike to the author may be very author-like to the schoolboy. Some of the more questionable extravagances to be found in the earlier portion of the volume, have, as I learn, pleased a good many young people; let us call these, and all the others that we have outgrown, Juvenile Poems, but keep them, lest some of the smaller sort that were, or are, or are to be, should lament their absence. I thought of mentioning the date at which the several poems were written, which would explain some of their differences; but the reader can judge them nearly enough, perhaps, without this assistance.

To save a question that is sometimes put, it is proper to say, that in naming two of the poems after two of the Muses, nothing more was intended than a suggestion of their general character and aim. In a former note of mine (which you printed as a kind of preface to the last edition), I made certain explanations which I thought might be needed; but as nobody seems to have misinterpreted any thing, we will trust our book hereafter to itself, not doubting that whatever is good in it will redeem and justify the rest.

Boston, January 13th, 1849.

The poems referred to in the first sentence of the above are five in number, to wit: "The Only Daughter" (the one accidentally omitted), "Lexington," "The Island Hunting-Song," "Questions and Answers," and "A Song for the Centennial Celebration of Harvard College, 1836." They are not added at the end of those printed in the earlier issue, but are inserted at pp. 182-195, between the "Song for a Temperance Dinner" and 
"Terpsichore," so that the pagination in the two issues corresponds only to p. 181. "Terpsichore" begins on p. 196, instead of on p. 182, as in the earlier issue, and the fourteen additional pages are thus accounted for.

This edition, in its final form, was reprinted many times, - nearly every year until 1861 . In the reprint of 1851, a frontispiece portrait of Dr. Holmes was first added to the other embellishments of the volume.

\section{ASTRAA}

Astrata: | the Balance of Illusions. | A Poem | delivered before the | Phi Beta Kappa Society of Yale College, | August 14, 1850, | by | Oliver Wendell Holmes. | Published by request of the Society.|Boston:| Ticknor, Reed, and Fields. | M DCCCL.

12mo, pp. 39 ; viz.: 1, title; 2 , copyright, and imprint (Boston: Thurston, Torry \& Company, Printers, Devonshire Street); 3-39, poem.

There are copies in boards, others in cloth.

This poem has never again been printed as written, except in the collection published in London (Routledge) in 1852. In Songs in Many Keys (1862) certain excerpts from it were printed in the group called Pictures from Occasional Poems, under these titles: "Spring," "The Study," "The Bells," "Non-Resistance," "The Moral Bully," and "The Mind's Diet," and they have continued to be so printed in the Household and all other collected editions.

In the Cambridge (1895) and Cabinet (1899) editions, the balance of the poem is printed in the Appendix, with indication of the original position of the above-named passages.

The following lines from that portion of "Astræa" which is now published under the title "Spring," were printed in Silhouettes and Songs, Illustrative of the 


\section{[ 130 ]}

Months, E. E. Hale, editor, 1876. "April" is the title there given to them.

At last young April, erer fresh and fair,

Wooed by her playmate with the golden hair,

Chased to the margin of receding floods

O'er the soft meadows starred with opening buds,

In tears and blushes sighs herself away,

And hides her cheek beneath the flowers of May.

\section{DEDICATION OF PITTSFIELD CEMETERY}

A Poem | by Oliver Wendell Holmes, | delivered at the dedication of the | Pittsfield Cemetery, | September 9, 1850.

Pamphlet, 8vo, pp. 8; viz.: 1, title; 2, blank; 3-8, poem.

This poem was printed also in a pamphlet containing the Rev. Mr. Neill's address, and other matter relating to the dedication. For a description of various forms of this pamphlet, see Appendix, p. 311, infra.

POEMS, 1852

The | Poetical Works | of | Oliver Wendell Holmes. | First English Edition. | London: G. Routledge \& Co., Farringdon Street. MDCCCLII.

32mo, pp. xvi, 296; illustrated; engraved half-title. Pp. iii-iv, The Author to the (American) Publisher [as in Poems, 1849, 2d issue]; $\mathrm{v}$-viii, contents; ix-xiv, introduction; $\mathrm{xv}$-xvi, poem, "To an English Friend;" 1-35, "Poetry: a Metrical Essay;" 1 36-46, "Terpsichore;" 47-81, "Urania;" 82-115, “Astræa;” 116-291, lyrics; 292-296, notes.

1 "The Cambridge Churchyard" and "Old Ironsides" are set apart in the table of contents, but not by title in the text. 


\section{[ 131 ]}

The lyrics include all the poems printed in the $2 \mathrm{~d}$ issue of the edition of 1849 , in the order there adopted, except for "Terpsichore" and "Urania;" also "The Ploughman," the "Poem for the Dedication of Pittsfield Cemetery," and the introductory lines "To an English Friend."

The notes to "Poetry" and to "Urania" are here printed at the end of the volume; in other early editions they follow the poems to which they respectively refer.

\section{AMERICAN MEDICAL ASSOCIATION}

Response | of | Oliver Wendell Holmes, M. D., | to the following Toast, proposed at the Entertainment given to the American/Medical Association, by the Physicians of the City of New York, | at Metropolitan Hall, on the 5th of May, 1853.

Toast. - "The union of Science and Literature - a happy marriage, the fruits of which are nowhere seen to better advantage / than in our American Holmes." |

[Then follows the poem, printed in Songs in Many Keys (1862), and in subsequent collections, under the title, "A Poem for the meeting of the American Medical Association, May 5, 1853.']

Published by the Committee of Arrangements and Reception of the American Medical Association.|Baker, Goodwin \& Co., Printers, 1 Spruce St., N. Y.

Broadside; all of the above, including poem, printed on one large page. 
POEMS OF THE CLASS OF 1829

Songs | of the | Class of mdcccxxix. | Printed for the use of the Class only. | [Scroll $] \mid$ Boston: - Prentiss and Sawyer, Printers, 1854. 8vo, pp. 12, paper.

Dr. Holmes's contributions are:-

A Song of '29. Written for the Annual Meeting, 1851, pp. 3-6. For the Class Meeting, Nov. 29, 1853. An Impromptu - Not Premeditated, p. 8.

Questions and Answers. From Holmes's Poems, pp. 10-11.

This little volume was printed during the winter of 1853-54, in accordance with a vote of the Class, passed at the meeting of Nov. 29, 1853.

Songs and Poems | of the | Class of | Eighteen Hundred and Twenty-Nine. Second Edition. | Printed for the use of the Class only. | [Scroll] | Boston:| Prentiss, Sawyer, \& Company, Printers, | 19 Water Street. | 1859.

8vo, pp. 46. Portrait of Dr. Holmes.

Dr. Holmes's contributions are:-

A Song of "Twenty-Nine." Written for the Annual Meeting, 1851, pp. 3-6.

An Impromptu - Not Premeditated. Written for the Class Meeting, Nov. 29, 1853, p. 10.

The Dream ["The Old Man Dreams"]. Written for the Class Meeting, Nov., 1854, pp. 14-16.

Song [" Remember - Forget"]. Written for the Class Meeting, Jan. 10, 1856, pp. 17-19.

A Poem ["Our Indian Summer"]. Written for the Class Meeting, Nov., 1856, pp. 20-21.

Mare Rubrum. Written for the Annual Meeting of the Class, 1858, pp. 22-24.

The Boys. Written for the Class Meeting, Jan. 6, 1859, pp. 29-31.

Questions and Answers. "From Holmes's Poems," pp. 45-46 (Appendix). 
Songs and Poems | of the | Class of | Eighteen Hundred and Twenty-Nine. / Third Edition. | Printed for the use of the Class only. | Boston:|Prentiss \& Deland, Book and Job Printers, | No. 40, Congress Street. | 1868.

$8 v o$, pp. 117. Collation of front matter is as follows: p. 1, title; 2, blank, with border; $3-5$, list of members of the Class; 6 , Class-Day officers; 7, present officers; 8, motto.

The poems begin on p. 9, and include the following by Dr. Holmes:-

A Song of "Twenty-Nine," pp. 9-12.

Questions and Answers ("For the Class, 1852"), pp. 12-13. An Impromptu, pp. 16-17.

The Dream, ${ }^{1}$ pp. 19-21.

Song, ${ }^{1}$ pp. $21-23$.

Poem, ${ }^{1}$ pp. 24-25.

Mare Rubrum, pp. 25-27.

The Boys, pp. 31-33.

Lines ["I'm ashamed - that's the fact," etc.]. Written for the Class Meeting, 1860, pp. 41-42.

A Voice of the Loyal North. Written for the Class Meeting, Jan. 3, 1861, pp. 59-61.

In Memory of J. D. R. Read at the Class Meeting, Jan. 23, 1862 , p. 63.

Voyage of the Good Ship Union. Read at the Class Meeting, Jan., 1862, pp. 64-67.

"Choose You this Day whom Ye will Serve." Read at the Class Meeting, Jan. 8, 1863, pp. 69-71.

Our Classmate, F. W. C. Written for the Class Meeting, Jan. 7, 1864, pp. 73-75.

The Last Charge. Read at the Class Meeting, Jan. 7, 1864, pp. 77-78.

Our Oldest Friend. Read to "The Boys of '29," Jan. 5, 1865 , pp. 80-82.

Sherman 's in Savannah! Written for the Class Meeting, Jan., 1865, p. 83.

${ }^{1}$ For the titles afterward given to these poems see Songs and Poems of the Class of 1829, edition of 1859 , p. 132, supra. 


\section{$[134]$}

My Annual. For the "Boys of '29."-At Annual Meeting, Jan. 4, 1866, pp. 84-86.

All Here, 1829-1867. Written for the Class Meeting, Jan. 10, 1867, pp. 90-92.

Once More. Condiscipulis, Coœtaneis, Harvardianis, Amicis.

Written for the Class Meeting, Jan., 1868, pp. 96-99.

The Appendix, pp. 113-117, contains two extracts from the "Autocrat."

The Class records state that this volume was printed "on tinted paper and entirely new type."

Additional | Songs and Poems | of the | Class of 1829. | 1868-1881.

8vo, pp. 119-197. "The paging of these 'Additional Songs and Poems' has been arranged with a view to their being bound with the original volume" (p. 120).

The following are Dr. Holmes's contributions:-

Bill and Joe, pp. 121-123.

Hymn, written for the Class, and sung at their meeting, Jan. $6,1869,{ }^{1}$ p. 124.

Lines, written for the Class Meeting, Jan. 6, 1869, ${ }^{2}$ pp. 125128.

Ad Sodales. Written for the Class Meeting, Jan. 6, 1870, ${ }^{3}$ pp. $130-135$.

Lines written for the Class Meeting, Jan. 5, 1871, ${ }^{4}$ pp. 137140.

Our Sweet Singer J. A. Written for the Class Meeting, Jan. 4, 1872, pp. 142-144.

Lines written for the Class Meeting, Jan. 9, 1873. H. C. M.

H. S. J. K. W., pp. 153-155.

What I have come for. Written for the Class Meeting, Jan. 9, 1873, pp. 155-156.

Lines written for the Class, Jan. 8, 1874, ${ }^{5}$ pp. 155-156.

Lines written for the Class Meeting, Jan. 7, 1875, ${ }^{6}$ pp. 160161.

1 "Hymn for the Class Meeting."

3 "Even-Song."

s "Our Banker."

2 "The Old Cruiser."

1 "The Smiling Listener."

6 "For Class Meeting." 


\section{[ 135 ]}

"Ad Amicos," 1829-1876. For the Class Meeting, Jan. 6, 1876, pp. 165-168.

How not to Settle It. Read to the Class, Jan. 4, 1877, pp. 168-173.

The Last Survivor. Read at the Meeting of Jan. 10, 1878, pp. 176-180.

A Dialogue, Senex - Juvenis. ${ }^{1}$ Read at the Class Meeting, Jan. 9, 1879, pp. 180-183.

Vestigia Quinque Retrorsum. An Academic Poem. Read at the Commencement Dinner of the Alumni of Harvard University, June 25, 1879, by Oliver Wendell Holmes; it being also the fiftieth anniversary of our class, pp. 186192.

The Shadows. Written for the Class Meeting, Jan. 8, 1880, pp. 192-194.

Benjamin Peirce. Astronomer, Mathematician. Read at the Class Meeting, Jan. 6, 1881, pp. 196-197.

It appears from the Class records that this volume was published in June, 1881.

The Latest Poems | of the | Class of 1829. | 1882-1889.

8vo, pp. 199-232. The pagination continues that of the edition of 1881 .

Contains the following poems by Dr. Holmes:-

Before the Curfew. Read at the Class Meeting, Jan. 5, 1882, pp. 204-208.

A Loving-Cup Song. Read at the Class Meeting, Jan. 4, 1883, pp. 211-212.

The Girdle of Friendship. Read at the Class Meeting, Jan. 10, 1884, pp. 213-214.

The Lyre of Anacreon. Read at the Class Meeting, Jan. 8, 1885, pp. 217-219.

The Old Tune. Thirty-Sixth Variation. Read at the Class Meeting, Jan. 7, 1886, pp. 219-220.

The Broken Circle. Read at the Class Meeting, Jan. 6, 1887, pp. 223-225.

1 Printed "with some changes" in the Atlantic Monthly for August, 1880, under the title "The Archbishop and Gil Blas." 


\section{[ 136 ].}

The Angel-Thief. Read at the Class Meeting, Jan. 5, 1888, pp. 225-226.

After the Curfew. Read at the Class Meeting, Jan. 10, 1889 , pp. 227-229.

Also an extract from Dr. Holmes's article in the Atlantic Monthly for Jan., 1890 (the first installment of "Over the Teacups"), pp. 229-232.

The Class records do not disclose the date of publication of this concluding volume of the poems written by its members for their annual meetings, but it was undoubtedly published during the year 1890 , as it contains an extract from the Atlantic for January of that year, and as the Rev. Mr. May's letter to the librarian of Harvard College, accompanying a copy, is dated January $9,1891$.

\section{THE NEW EDEN}

The New Eden. | Read before the Berkshire Horticultural Society, at $\mid$ Stockbridge, Sept. 13, 1854. | By Oliver Wendell Holmes.

Broadside, small 8vo, pp. 4; viz. : 1, title; 2-4, poem.

Mr. J. E. A. Smith, in The Poet among the Hills, states that, after reading the poem, Dr. Holmes acceded to the request of a local editor who wished to print it, on condition that he should have as many proofs and make as many alterations as he chose, and should have a hundred copies of the poem printed by itself. He had sixteen proofs and doubled the length of the poem, besides giving it a more serious tone.

\section{THE PROMISE}

The Promise. A Poem written for Harriet Ryan's Fair, for a Home for Destitute and Incurable Women. March 20, 1859. Boston, 1859. 


\section{[ 137 ]}

Leaflet, 8vo, pp. 4. Poem on p. 1, signed O. W. Holmes, March 20th, 1859; other pages blank.

\section{VIVE LA FRANCE}

The |Address of Mr. [Edward] Everett| and the | Pozm of Dr. O. W. Holmes, | at the Dinner given to $\mid$ H. I. H. Monseigneur | The Prince Napoleon, | September 25th, 1861. Cambridge: | Privately Printed. | 1861.

8vo, pp. i-iv, 5-20; viz.: i, title; ii, imprint (Riverside, Cambridge: Printed by H. O. Houghton); iii-iv, introductory note; 5-16, Mr. Everett's address; 17, half-title (Poem by O. W. Holmes); 18, blank; 19-20, poem ("Vive la France!").

\section{SONGS IN MANY KEYS}

Songs In MANY Keys. | By | Oliver Wendell Holmes. | Boston: Ticknor and Fields. | 1862. | [c. 1861.]

8vo, pp. x, 308. Page i, title; ii, copyright, and imprint (University Press, Cambridge: Stereotyped and Printed by Welch, Bigelow \& Co.); iii, dedication, "To the most indulgent of readers, the kindest of critics, my beloved mother, all that is least unworthy of her in this volume is dedicated by her affectionate son;" iv, blank; v, verse, ${ }^{1}$ beginning "The piping

${ }^{1}$ In all collected editions of Dr. Holmes's poems the title "Songs in Many Keys" has been given to a group corresponding in the main to the contents of this volume, but varying slightly from time to time, and these lines are printed at the head of that group in every case. In the various issues of the Household Edition they have no separate title, but in the Riverside, Cambridge, and Cabinet Editions, they are entitled "Prologue." 


\section{[ 138 ]}

of our slender, peaceful reeds;" vi, blank; vii- $x$, contents; 1-305, poems; 306, blank; 307-308, note to "Agnes."

A list of the poems follows; none of them had previously appeared in any collection, with these exceptions: "The Ploughman," the "Poem for the Dedication of the Pittsfield Cemetery," and the lines "To an English Friend" were included in the London edition of 1852; and "Spring," "The Study," "The Bells," "Non-Resistance," "The Moral Bully," and "The Mind's Diet" are excerpts from "Astræa," which was printed entire in that edition.

\section{Agnes. ${ }^{1}$}

The Ploughman.

A Poem for the Dedication of the Pittsfield Cemetery.

Pictures from Occasional Poems, 1850-1856.

Spring.

The Study.

The Bells.

Non-Resistance.

The Moral Bully.

The Mind's Diet.

Our Limitations.

The Old Player. ${ }^{2}$

The Island Ruin.

The Banker's Dinner.

The Mysterious Mlness.

A Mother's Secret.

The Disappointed Statesman.

The Secret of the Stars.

To Governor Swain.

To an English Friend.

Vignettes.

After a Lecture on Wordsworth.

${ }^{1}$ In the poem as here printed (part ii, stanza 28), and in all subsequent reprintings except the Riverside, Cambridge, and Cabinet Editions, Agnes's surname is spelled Surraige; in those editions it is changed to Surriage, the form adopted by Mr. E. L. Bynner, in his romance.

2 For the history of this and the six following poems, see supra, p. 20. 


\section{[ 139 ]}

After a Lecture on Moore.

After a Lecture on Keats.

After a Lecture on Shelley.

After a Course of Lectures.

The Hudson.

A Poem for the Meeting of the American Medical Association. The New Eden.

A Sentiment ("A triple health to Friendship, Science, Art"). Semicentennial Celebration of the New England Society (Dec. 22, 1855).

Ode for Washington's Birthday.

Class of '29 (Nov. 6, 1856).

For the Meeting of the Burns Club (1856).

For the Burns Centennial Celebration (Jan. 25, 1859).

Birthday of Daniel Webster (Jan. 18, 1856).

Meeting of the Alumni of Harvard College (1857).

The Parting Song (1857).

Boston Common - Three Pictures, 1630, 1774, 186- (1859).

Latter-Day Warnings.

Prologue [from the "Autocrat"].

The Old Man of the Sea.

Ode for a Social Meeting, with Slight Alterations by a Teetotaler.

The Deacon's Masterpiece: or the Wonderful "One-Hoss Shay."

Estivation.

Contentment.

Parson Turell's Legacy.

De Sauty.

The Old Man Dreams.

Mare Rubrum.

What we all Think.

Spring has Come.

A Good Time Going.

The Last Blossom.

"The Boys."

The Opening of the Piano.

Midsummer.

A Parting Health. To J. L. Motley (1857).

A Good-by. To J. R. Lowell (1855).

At a Birthday Festival. To J. R. Lowell (Feb. 22, 1858). 


\section{[ 140 ]}

A Birthday Tribute. To J. F. Clarke (April 4, 1860).

The Gray Chief (1859).

The Last Look. W. W. Swain (Sept. 22, 1858).

In Memory of Charles Wentworth Upham, Junior (1860).

Martha (Died Jan. 7, 1861).

Sun and Shadow.

The Chambered Nautilus.

The Two Armies.

For the Meeting of the National Sanitary Association (1860).

Musa.

The Voiceless.

The Crooked Footpath.

The Two Streams.

Robinson of Leyden.

Saint Anthony the Reformer.

Avis.

Iris, her Book.

Under the Violets.

The Promise.

The Living Temple.

Hymn of Truth.

A Sun-Day Hymn.

A Voice of the Loyal North. National Fast, Jan. 4, 1861.

Brother Jonathan's Lament for Sister Caroline.

Under the Washington Elm, Cambridge (April 27, 1861).

International Ode. Our Father's Land. Sung in unison by 1200 children of the public schools, at the visit of the Prince of Wales to Boston, October 18, 1860.

Freedom, our Queen.

Army Hymn.

Parting Hymn.

The Flower of Liberty.

The Sweet Little Man.

Vive la France! Dinner to Prince Napoleon, Revere House, Sept. 25, 1861.

Union and Liberty.

It will be noticed that, while the poems scattered through the "Autocrat" and "Professor" are given a place in this volume, they are curiously intermingled and are not arranged according to any system which 


\section{[ 141 ]}

one can readily grasp. At this time (1862) Dr. Holmes had long since acquired the habit of reading an annual poem to the Class of '29, but his contributions of 1851, 1853 , and 1855 are omitted from this collection. They had already been printed in the Songs of the Class, but so had "The Old Man Dreams" (1854), "Our Indian Summer" (1856), "Mare Rubrum" (1858), and "The Boys" (1859), which are included in this volume.

Apparently reprinted several times.

\section{POEMS : BLUE AND GOLD EDITION}

The Poems | of | Oliver Wendell Holmes. | [Ornament] | [Device] | Boston: | Ticknor and Fields. | 1862.

Blue and Gold Edition; 32mo, pp. xii, 410, followed by blank leaf, list of Blue and Gold books, another blank leaf, and a list of books published by Ticknor \& Fields (16 pages). Collation is as follows: Portrait (frontispiece, facing title); i, title; ii, copyright, and imprint (University Press: Welch, Bigelow, and Company, Cambridge); iii-v, verse, "To my Readers," dated April 8, 1862; ${ }^{1}$ vi, blank; vii-xi, contents; xii, blank; 1, half-title ("Poetry: a Metrical Essay"); 2, blank; 3, dedication of "Poetry;" 4, blank; 5-32, "Poetry;" 33, half-title (Miscellaneous Poems); 34, blank; 35-190, poems; 191, half-title (Songs in Many Keys); 192, blank; 193, dedication (to his mother); 194, blank; 195-402, poems; 403, half-title (Notes); 404, blank; 405-410, notes. Floriated initial letters throughout, and ornaments on half-titles and dedication pages.

1 Printed in all subsequent collected editions as the opening poem. 


\section{[ 142$]$}

This edition contains, in addition to all the poems included in the 2d issue of 1849, and in Songs in Many Keys, 1862, the "Voyage of the Good Ship Union," on pp. 398-401, before "Union and Liberty," which closes the volume. "The Cambridge Churchyard" and "Old Ironsides" were first printed as separate poems in this edition, which was reprinted many times.

\section{SONGS OF MANY SEASONS}

Songs of Many Seasons. $\mid$ 1862-1874. $\mid$ By Oliver Wendell Holmes. |[Device]| Boston: James R. Osgood and Company, | late Ticknor \& Fields, and Fields, Osgood, \& Co. 1875. [c. 1874.]

12mo, pp. xii, 216. Collation is as follows: i, title; ii, copyright, and imprint (University Press: Welch, Bigelow, \& Co., Cambridge); iii-iv, verse, "Opening the Window;" iv-vii, verse, "Programme," dated Oct. 7, 1874; viii, blank; ix-xii, contents; 1-216, poems, divided into groups, as follows:-

IN the Quiet DaYs, pp. 1-40:

An Old-Year Song, 1874.

Bill and Joe, 1868.

Dorothy Q. 1871.

The Organ-Blower, 1872.

Homesick in Heaven, ${ }^{1} 1872$.

Fantasia. The Young Girl's Poem, ${ }^{1} 1872$.

Aunt Tabitha. The Young Girl's Poem, ${ }^{1} 1872$.

At the Pantomime, 18-, rewritten 1874.

After the Fire, 1872.

A Ballad of the Boston Tea-Party, 1874.

Epilogue to the Breakfast-Table Series, 1872. ${ }^{1}$

Nearing the Snow-Line.

IN WAR Time, pp. 41-62:

To Canaan. A Puritan War-Song, 1862.

${ }^{1}$ From "The Poet at the Breakfast-Table." 


\section{[ 143 ]}

Thus Saith the Lord, 1862.

Choose You this Day, etc., 1863.

Never or Now! An Appeal, 1862.

The Last Charge, 1864.

Our Country, 1865.

Sherman's in Savannah! A Half-Rhymed Impromptu, 1865.

God Save the Flag, 1865.

Hymn - After the Emancipation Proclamation, 1865.

Hymn for the Fair at Chicago, 1865.

Songs of Welcome and Fareweld, pp. 63-97:

America to Russia. Read by Hon. G. V. Fox at a dinner given to the Mission from the United States, St. Petersburg, Aug. 5, 1866.

Welcome to the Grand Duke Alexis, Music Hall, Dec. 9, 1871. At the Banquet to the Grand Duke Alexis, Dec. 9 [11], 1871. At the Banquet to the Chinese Embassy, Aug. 21, 1868.

At the Banquet to the Japanese Embassy, Aug. 2, 1872.

Bryant's Seventieth Birthday, Nov. 3, 1864.

At a Dinner to General Grant, July 31, 1865.

At a Dinner to Admiral Farragut, July 6, 1865.

A Toast to Wilkie Cullins, Feb. 16, 1874.

To H. W. Longfellow. Before his Departure for Europe, May 27, 1868.

To Christian Gottfried Ehrenberg. For his Jubilæum at Berlin, Nov. 5, 1868.

Memorial Verses, pp. 98-128:

For the Services in Memory of Abraham Lincoln, June 1, 1865.

For the Commemoration Services, Cambridge, July 21, 1865.

Edward Everett, Our First Citizen, Jan. 30, 1865.

Shakespeare Tercentennial Celebration, April 23, 1864.

In Memory of John and Robert Ware, May 25, 1864.

Humboldt's Birthday. Centennial Celebration, Sept. 14, 1869.

Poem at the Dedication of the Halleck Monument, July 8, 1869.

Hymn for the Celebration at the Laying of the Corner-Stone of Harvard Memorial Hall, Oct. 6, 1870.

Hymn for the Dedication of Memorial Hall at Cambridge, June 23, 1874.

Hymn at the Funeral Services of Charles Sumner, April 29, 1874. 


\section{[144]}

RhyMes of aN Hour, pp. 129-166:

Address for the Opening of the Fifth Avenue Theatre, New York, Dec. 3, 1873.

Rip Van Winkle, M. D. An After-Dinner Prescription taken by the Massachusetts Medical Society, at their meeting held May 25, 1870.

Chanson without Music. By the Professor Emeritus of Dead and Live Languages, 1867.

For the Centennial Dinner of the Proprietors of Boston Pier, or the Long Wharf, April 16, 1873.

A Poem Served to Order. Phi Beta Kappa, June 26, 1873.

The Fountain of Youth. Read at the Meeting of the Harvard Alumni Association, June 25, 1873.

A Hymn of Peace. Sung at the "Jubilee," June 15, 1869.

For Meetings of the Class of 1829, pp. 167-216:

Our Classmate F. W. C., 1864.

Our Oldest Friend, 1865.

My Annual, 1866.

All Here, 1867.

Once More, 1868.

The Old Cruiser, 1869.

Hymn for the Class-Meeting, 1869.

Even-Song, 1870.

The Smiling Listener, 1871.

Our Sweet Singer, J. A., 1872.

H. C. M., H. S., J. K. W., 1873.

What I have Come For, 1873.

Our Banker, 1874.

\section{GRANDMOTHER'S STORY OF BUNKER HILL} BATTLE

[Private Copy.] ${ }^{1}$ Grandmother's Story of Bunker-Hill Battle | as she saw it from the Belfry. | By Oliver Wendell Holmes. [1875.]

Pamphlet, folio, pp. 10. Printed in very large type, on right-hand page only. Six copies printed.

1 These brackets are in the original. 


\section{[ 145 ]}

On the title-page of the copy in the Boston Public Library Dr. Holmes wrote, "for old eyes."

Grandmother's Story of Bunker-Hill BatTLE, by Oliver Wendell Holmes. Illustrated by H. W. McVickar. Imprinted at New York by Dodd, Mead \& Company by arrangement with Houghton, Mifflin \& Co. [c. 1883.]

Square 8vo, pp. 32. Illustrated in color; full-page cuts, and cut on each page of text.

The Same. With Biography and Notes by Margaret Hill McCarter. Topeka, Kansas, Crane $\&$ Co., 1904.

12mo, pp. 69. Contains a "guide to the study of Oliver Wendell Holmes."

The earliest publication of this poem was in the copyrighted volume, Memorial-Bunker Hill, issued by James R. Osgood \& Co., which contained also 12 pages of historical matter, written by James M. Bugbee, Esq. See p. 31, supra, note.

\section{A FAMILY RECORD}

A Family Record. Woodstock, Connecticut, July 4th, 1877.

Pamphlet, 4to, pp. 11. Poem begins on page 1, under above heading. Only very few copies printed.

In the correspondence accompanying the copy now in the Library of Harvard College, Dr. Holmes states that the pamphlet was printed for him at "Mr. Clapp's Printing Office."

This poem was read at Roseland Park, Conn., during the annual celebration of Independence Day under the auspices of Dr. Bowen of the Independent. "The Ship of State" was read on the same occasion. 


\section{POEMS, HOUSEHOLD EDITION}

The | Poetical Works | of | Oliver Wendell Holmes. | Household Edition. | [Device] Boston:|Houghton, Osgood and Company. | The Riverside Press, Cambridge. | $187 \%$.

$8 \mathrm{vo}$, pp. xii, 322. The collation is as follows: i, half-title; ii, blank; iii, title; iv, copyright; $\mathrm{v}-\mathrm{x}$, contents; xi, "To my Readers" [verse]; xii, blank; 1-320, poems; 321-322, notes.

The Household was the first collected edition of Dr. Holmes's poems after the Blue and Gold Edition of 1862. It included all of those contained in the edition of 1836, except "A Souvenir," “The Dying Seneca," “The Last Prophecy of Cassandra," and "To my Companions;" all of the edition of 1849; all of the Songs in Many Keys; "The Voyage of the Good Ship Union" (which was the only "uncollected" poem in the Blue and Gold Edition); all of the Songs of Many Seasons; and some additional poems, a list of which will be given a little later. The contents of the volume were arranged thus:-

Earlier Poems (1830-1836).

This group contained eighteen of the Poems of 1836, "Poetry: a Metrical Essay," coming last. "Old Ironsides" and "The Cambridge Churchyard" are again printed separately.

Additional Poems (1837-1848).

This group contained twenty-one of the poems added in the edition of $1849,2 \mathrm{~d}$ issue.

Miscellaneous Poems (1830, etc.).

This group contained all the rest of the poems printed in 1836 and 1849, except the four named above, and except also "Questions and Answers," which was here placed among the Poems of the Class of '29.

${ }^{1}$ Written as an introduction to the Blue and Gold Edition. 


\section{[ 147 ]}

Songs IN MANy Keys (1849-1861).

This group was divided into I, 1849-1856, and II, 1857-1861. The two divisions embraced the poems contained in the volume of this title, with the exception of most of those originally published in the "Autocrat" and "Professor," and those written for the Class of '29, which were printed in separate groups.

Poems from the Autocrat of the Breakfast-Table: (1857-1858).

"The Living Temple" and "The Voiceless" were omitted from this group, for some unfathomable reason, and left in the second division of Songs in Many Keys; while "The Old Man Dreams" and "Mare Rubrum," which were originally written for meetings of the Class of '29, were placed in that group. "Album Verses" had not previously been collected.

Poems from the Professor at the Breakfast-Table (1858-1859).

"A Mother's Secret" was printed among the Pictures from Occasional Poems in the first division of Songs in Many Keys; "The Two Streams" and "At a Birthday Festival," in the second division of the same group; and "The Boys," among the Class poems.

Poems from the Poet at the Breakfast-Table (18711872).

"J[oseph] A[ngier]" was printed in the next following group under the title "Our Sweet Singer - J. A." "Wind-Clouds and Star-Drifts" here first collected.

Poems of the Class of '29 (1851-1877).

This group includes all the songs and poems found in the third edition of the Cliss publication (1868), together with "Bill and Joe" (placed at the head of the group), and the following additional pieces:-

The Old Cruiser (1869).

Hymn for the Class-Meeting (1869).

Even-Song (1870).

The Smiling Listener (1871).

Our Sweet Singer - J. A. (1872).

H. C. M. H. S. J. K. W. (1873).

What I have Come For (1873).

Our Banker (1874). 


\section{$[148]$}

For Class Meeting (1875).

Ad Amicos (1876).

How Not to Settle It (1877).

Of these Class poems the following had not previously appeared in any collection of Dr. Holmes's works, except the privately printed Class publications: "A Song of '29," "An Impromptu - Not Premeditated," "Remember - Forget," "For Class Meeting" (1875), "Ad Amicos" (1876), and "How Not to Settle It" (1877).

Songs of Many Seasons (1862-1874).

The poems contained in the volume of this title are here reprinted under the same subdivisions and in the same order, with these omissions: "Homesick in Heaven," "Fantasia," "Aunt Tabitha," and the "Epilogue to the Breakfast-Table Series," which are printed under the separate heading of "Poems from the Poet at the Breakfast-Table;" "Bill and Joe," "Choose You this Day," "The Last Charge," "Sherman's in Savannah," and the whole subdivision "For Meetings of the Class of '29," all of which appear in the preceding group.

Adpitional Poems (то 1877).

At a Meeting of Friends, August 29, 1859.

A Farewell to Agassiz.

A Sea Dialogue.

At the "Atlantic Dinner," December 15, 1874.

"Lucy." For her Golden Wedding, October 18, 1875.

Hymn for the Inauguration of the Statue of Governor Andrew, at Hingham, October 7, 1875.

A Memorial Tribute.

Joseph Warren, M. D.

Grandmother's Story of Bunker-Hill Battle.

Old Cambridge, July 3, 1875.

Welcome to the Nations, Philadelphia, July 4, 1876.

A Familiar Letter.

Unsatisfied.

How the Old Horse Won the Bet. An Appeal for "the Old South."

The First Fan.

To R. B. H.

"The Ship of State."

A Family Record. 


\section{[ 149 ]}

"A Farewell to Agassiz" and "A Sea Dialogue" had previously appeared in the Humorous Poems, 1865; none of the others had been printed in any collection.

First Verses. Phillips Academy, Andover, Mass., 1824 or 1825.

These verses (a translation from the Eneid Bk. I) fill the last page of the text (320).

Reprinted without change in 1880 .

The Same. Household Edition. With Illustrations. Boston, 1878.

The Same. Boston and New York, Houghton, Miffin and Company, 1887.

$8 \mathrm{vo}$, pp. xiv, 357; with frontispiece portrait, and 8 full-page cuts. The collation is as follows: i, blank; ii, panel advertisement of other books "by the same author;" iii, title; iv, copyright and imprint; $\mathrm{v}-\mathrm{x}$, contents; $\mathrm{xi}$, list of illustrations; xii, blank; xiii, “To my Readers;" xiv, "From the first gleams of morning to the gray" (Prelude to Poems, Handy Volume Edition, 1881, since called "Rhymes of a Lifetime”); 1-351, poems; 352, blank; 353-354, notes; $355-357$, index of titles.

Pages 1 to 320 are printed from the same plates as the earlier impressions of the Household; on pages 321 to 351, under the group heading The Iron Gate, and Other Poems, are printed the contents of the volume of that title which was published in 1880 , the order being unchanged.

The Same. Boston and New York, Houghton, Miffin \& Co. [1895.]

$8 \mathrm{vo}$, pp. xviii, 426. Collation of front matter is as follows: i, title; ii, copyright; iii, Pub- 


\section{[150]}

lishers' Note; ${ }^{1}$ iv, blank; v-vi, Biographical Sketch; vii-xiv, contents; $\mathrm{xv}$, list of illustrations; xvi, blank; xvii, "To my Readers;" xviii, "From the first gleams of morning," etc.

This edition is printed from the old plates to p. 351; pp. 352-409 contain, under the general heading Before the Curfew, and Other Poems, the poems printed in the volume of that title (1888), in the same order there adopted, together with others of later date; and pp. 410416, a group of Poems from Over the Teacups. The notes are on pp. 417-418, and there are indexes of first lines (419-422), and titles (423-426).

As the plates of the earlier impressions of the Household were used, it was impossible to adopt the more logical arrangement followed in the Riverside Edition, and still further improved in the Cambridge Edition.

\section{Poems, Boston, James R. Osgood \& Co., 1877.}

\section{Library Edition.}

Substantially uniform with Household Edition. The compiler's knowledge of this edition is limited to a bare mention of it in an old catalogue.

\section{THE SCHOOL-BOY}

The School-Boy. | By | Oliver Wendell Holmes. | With Illustrations. |[Device]| Boston:|Houghton, Osgood and Company. | The Riverside Press, Cambridge. | 1879.

8vo, pp. 79 (i-x, 11-79), with 28 full-page 1 "When the Riverside Edition of Dr. Holmes's complete works was issued about three years before his death, he took advantage of the opportunity to decide finally what poems, printed up to that time, he wished to preserve. Later, the publishers added the few poems written after the author's selection was made, and a few other fugitive pieces which had then escaped his notice. The contents of the present Household Edition are substantially the same as those of the three volumes in the Riverside Fdition devoted to poems, though the order of arrangement varies slightly." 


\section{[ 151 ]}

and text cuts. Collation: i, blank; ii, frontispiece; iii, title; iv, copyright [1878]; v, dedication: "To the Students of Phillips Academy, Andover, Massachusetts. Read at the Centennial Celebration, June 6, 1878;" vi, blank; vii, ix, list of illustrations; viii, x, blank; 11, half-title; 12, blank; 13-79, poem, printed on right-hand pages only.

Issued in England with imprint of G. Routledge \& Sons.

\section{THE IRON GATE, AND OTHER POEMS}

The Iron Gate, | and Other Poems. $\mid$ By | Oliver Wendell Holmes. [ [Device $]$ Boston: Houghton, Miffin and Company. | The Riverside Press, Cambridge. | 1880.

8vo, portrait, pp. 82. Collation: 1, title; 2, copyright, and imprint (Riverside, Cambridge: Stereotyped and Printed by H. O. Houghton and Company); 3, contents; 4, blank; 5-82, poems.

Contents:-

The Iron Gate.

Vestigia Quinque Retrorsum. An Academic Poem, 1829-1879.

My Aviary.

On the Threshold.

To George Peabody.

At the Papyrus Club.

For Whittier's Seventieth Birthday.

Two Sonnets: Harvard.

The Last Survivor.

The Archbishop and Gil Blas.

The Shadows.

The Coming Era.

In Response.

For the Moore Centennial. 


\section{[ 152 ]}

To James Freeman Clarke.

Welcome to Chicago Commercial Club.

American Academy Centennial Celebration.

The School-Boy.

The Silent Melody.

\section{POEMS, HANDY VOLUME EDITION}

The | Poetical Works | OF | Oliver Wendell Holmes | Volume I [II] | [Device] | Boston | Houghton, Miffin and Company|The Riverside Press, Cambridge | 1881.

32mo; vol. i, pp. xiv, 444; vol. ii, pp. viii, 427. Collation of vol. i: i, title; ii, copyright and imprint; iii, "From the first gleam of morning to the gray" (sonnet, now called "Rhymes of a Lifetime"); iv, blank; v-vii, "To my Readers;" viii, blank; ix-xiv, contents; 1-444, poems. Collation of vol. ii: i, title; ii, copyright and, imprint; iii-vii, contents; viii, blank; 1-413, poems; 414, blank; 415-418, notes; $419-427$, index of first lines. Vol. ii has a frontispiece portrait.

The contents are divided into the same groups as in the Household Edition, each group having a separate half-title, and the order of the poems is unchanged from that edition, except that "Vestigia Quinque Retrorsum," "The Last Survivor," "The Archbishop and Gil Blas," and "The Shadows" are taken from The Iron Gate collection and placed at the end of the Poems of the Class of '29. Under the heading The Iron Gate, and Other Poems," at the end of vol. ii, are printed the contents of the volume of that title, less the four poems named above, and plus these four, now first collected, viz.: "Boston to Florence," "Post-Prandial," "Our Home- 
Our Country," and "Poem for the Centennial Anniversary Dinner of the Massachusetts Medical Society."

Issued in England with imprint of Sampson Low \& Co.

The catalogue of the British Museum contains an entry of a "revised edition" of Dr. Holmes's "Poems," published by Routledge \& Sons (pp. xii, 324), in 1881; and of his "Poetical Works," published by the same firm in its "Excelsior Series," in 1883.

\section{THE LAST LEAF}

The Last Leaf | Poem | by | Oliver Wendell Holmes | Illustrated by | George Wharton Edwards \& F. Hopkinson Smith | [Device] | Houghton, Mifflin \& Co. | The Riverside Press, Cambridge, | M DCCCLXxxv.

4to, decorated cloth, pp. 54, with decorative borders and many full-page plates. Rubricated title. Pp. 3-9 and 52-54 are right-hand pages; pp. $10-51$ are printed on one side only, text on left-hand page, cut on right-hand. Pp. 3-5, list of illustrations. On pp. 6-8 is a facsimile of a manuscript copy of the poem; on pp. 5254, "The History of this Poem," by Dr. Holmes, dated Beverly Farms, July 9, 1885.

In the "history" Dr. Holmes says: "Just when it was written I cannot exactly say, nor in what paper or periodical it was first published. It must have been written before April, 1833; probably in 1831 or 1832. It was republished in the first edition of my poems, in the year 1836." The fact is that the poem was first published in the Amateur for March 26, 1831, no. 17. See p. 205, infra. 


\section{[ 154]}

The "history" is given almost in full in the Cambridge Edition, 1895, pp. 4-5. The false rhyme in the 3d stanza, there referred to, was corrected in 1836, "sad and wan" being substituted for "so forlorn," in the $3 \mathrm{~d}$ line.

\section{The Same. Boston; Houghton, Miffin \& Co.,} 1894.

8vo, pp. 55, with the decorative borders and illustrations of the quarto edition reproduced in smaller format.

Issued in England, with imprint of Sampson Low \& Co.

The two editions correspond exactly, page for page, except in these respects: between the title-page and list of illustrations is a two-page letter from Dr. Holmes to the publishers, in facsimile, dated Beverly Farms, July 12, $1894 ;^{1}$ on pp. $6-8$, the poem is printed in ordinary type; the text and illustrations are printed on alternate righthand pages; and the "history of the poem," at the end, fills four pages, 52-55.

Dr. Holmes's letter is printed in the Cambridge Edition, p. 5 . It reads thus: "I have read the proof you sent me and find nothing in it which I feel called upon to alter or explain.

"I have lasted long enough to serve as an illustration of my own poem. I am one of the very last of the leaves which still cling to the bough of life that budded in the spring of the nineteenth century. The days of my years are threescore and twenty, and I am almost halfway up the steep incline which leads me toward the base of the new century so near to which I have already climbed.

"I am pleased to find that this poem, carrying with it the marks of having been written in the jocund morning of life, is still read and cared for. It was with a smile on my lips that I wrote it; I cannot read it without a sigh of tender remembrance. I hope it will not sadden my older readers, while it may amuse some of the younger ones to whom its experiences are as yet only floating fancies."

1 Dr. Holmes died in October, 1894. 


\section{$[155]$}

TRANSLATION

La Derniere Feuille. Traduit du texte americain par B. H. Gausseron. Paris, Quantin, 1889.

4to. Illustrated by F. H. Smith and G. W. Edwards.

This French version of "The Last Leaf" is printed by Mr. Morse in the Life and Letters, vol. ii, pp. 98-100.

\section{POEMS, FAMILY EDITION}

Poems, Family Edition. Boston, Houghton, Miffin \& Co., 1887.

BEFORE THE CURFEW, AND OTHER POEMS

Before the Curfew | and Other Poems Chiefly | Occasional | by | Oliver Wendell Holmes | [Device $]$ | Boston and New York | Houghton, Mifflin and Company | The Riverside Press, Cambridge | 1888.

16mo, pp. vi, 110. Collation: i, title; ii, copyright and imprint; iii, "At my Fireside" (verse), dated March 1, 1888; iv, blank; v-vi, contents; 1-110, poems.

Contents:-

Before the Curfew, 1829-1882.

A Loving-Cup Song, 1829-1883.

The Girdle of Friendship, 1829-1884.

The Lyre of Anacreon, 1829-1885.

The Old Tune, Thirty-sixth Variation, 1829-1886.

The Broken Circle, 1829-1887.

The Angel-Thief, 1829-1888.

At the Saturday Club.

Benjamin Peirce: Astronomer, Mathematician, 1829-1880.

Our Dead Singer. H. W. L. 


\section{[ 156 ]}

To James Freeman Clarke, April 4, 1880.

Two Poems to Harriet Beecher Stowe on her Seventieth Birthday, June 14, 1882.

I. At the Summit.

II. The World's Homage.

A Welcome to Dr. Benjamin Apthorp Gould.

To Frederick Henry Hedge.

To James Russell Lowell.

To John Greenleaf Whittier, on his Eightieth Birthday, 1887.

Prelude to a Yolume printed in Raised Letters for the Blind.

Boston to Florence.

At the Unitarian Festival, March 8, 1882.

Poem for the 250th Anniversary of Harvard College.

Of these poems, two - "To James Freeman Clarke" and "Boston to Florence" - had already appeared in collected editions, - the former in The Iron Gate, and Other Poems, and in the revised Household Edition of 1887, - and both in the Handy Volume Edition, 1881.

Issued in England with imprint of Sampson Low \& Co.

\section{POEMS, RIVERSIDE EDITION}

The Poetical Works / of / Oliver Wendell Holmes. | In Three Volumes | Volume I [II] [III] $\mid[$ Device $] \mid$ Boston and New York | Houghton, Miffin and Company | The Riverside Press, Cambridge | MDCCCXCI.

Crown 8vo; pp. $\mathrm{x}, 287$; $\mathrm{x}, 307$; viii, 294. Portrait in vol. i. Pp. ix-x of vol. i: "To my Readers."

The rearrangement of the poems which was made, under Dr. Holmes's supervision, for this edition, was sadly needed; there had been no collected edition approaching completeness except the Household and the Handy Volume, and the successive reissues of the Household had been made by simply adding new plates for such poems as had been published since the last preceding issue. Thus, for instance, some of the Poems of 


\section{[ 157 ]}

the Class of '29 were printed under that heading, some under Songs of Many Seasons, some under Before the Curfew, and Other Poems, some under The Iron Gate, and Other Poems; while some other unclassified poems were unaccountably omitted altogether.

In the Riverside the following new categories were made up, viz.: Medical Poems, and Readings over the Teacups; while the Miscellaneous Poems (1830, etc.) of the Household, including those of his earlier productions to which Dr. Holmes was least partial, were placed at the end of the third volume, under the heading, Verses from the Oldest Portfolio.

In making up this edition some poems were accidentally omitted, and the omission is noted in each case in the first part of this bibliography.

POEMS, EDINBURGH, 1892

Poetical Works of Oliver Wendell Holmes. Edinburgh, David Douglas, 1892.

4 vols., $12 \mathrm{mo}$.

\section{THE ONE-HOSS SHAY, ETC.}

The One-Hoss Shay | With its Companion Poems | How the Old Horse Won the Bet $|\&|$ The Broomstick Train | by Oliver Wendell Holmes | with Illustrations by | Howard Pyle | [Device]|Boston and New York|Houghton, Miffin and Company|The Riverside Press, Cambridge | M DCCC XCII.

8 vo, pp. 80 ; rubricated title-page, frontispiece, head- and tail-pieces, and about sixty full-page and text cuts. Preface by the author, dated July, 1891.

Printed on right-hand page only. 


\section{[ 158 ]}

The Same. Christmas Edition.

With colored illustrations.

The Same. Boston and New York, Houghton, Mifflin \& Co., 1905.

Reprinted from new plates, with illustrations in colors.

\section{DOROTHY Q}

Dorothy Q [red] | Together with | A Ballad of the Boston Tea Party | \& | Grandmother's Story of Bunker Hill Battle | By Oliver Wendell Holmes [red] | with Illustrations by | Howard Pyle |[Device $]$ | Boston and New York | Houghton, Miffin and Company | The Riverside Press, Cambridge | M DCCC XCII.

12mo, pp. 131. Half-titles for each of the three poems; many full-page cuts, borders, vignettes, etc.

250 copies printed on large paper. Issued in England with imprint of Gay and Bird.

\section{POEMS, CAMBRIDGE EDITION}

The Complete | Poetical Works of | Oliver Wendell Holmes | Cambridge Edition | [Cut of the "Gambrel-Roofed House," Cambridge]| Boston and New York | Houghton, Mifflin and Company | The Riverside Press, Cambridge. [1895.]

8vo, pp. xxii, 352; engraved title-page; portrait. Collation: i, title; ii, copyright; iii, Publishers' Note; iv, blank; v-ix, contents; $\mathrm{x}$, blank; xi-xxi, Biographical Sketch, by H. E. S[cudder]; xxii, blank; 1-2, “To my 
Readers ;" 3-320, poems; 321-344, appendix; $345-348$, index of first lines; 349-352, index of titles.

Issued in England with imprint of Sampson Low \& Co.

The arrangement of the poems follows in the main that adopted in the Riverside Edition; but the poems printed at the end of the third volume of that edition are here relegated to the Appendix, and printed in smaller type, together with four poems, which had been omitted altogether in both Riverside and Household Editions, namely: "A Souvenir," “The Dying Seneca," "The Last Prophecy of Cassandra," and "To my Companions." The Appendix also contains (pp. 333-337) the long poem, "Astræa," except those portions which have always been printed under separate titles (see p. 129). Also (pp. 337-341) Notes and Addenda, the latter category including the Report of the Committee on the Ploughing Match (at the Anniversary of the Berkshire Agricultural Society, 1849), and a list of the Members of the Class of '29. Also a Chronological List of Dr. Holmes's poems, in which, "whenever the first appearance of a poem has been not precisely determined, the title is printed in italic under the year when the volume first including it was published."

In this edition are collected for the first time: (1) a number of poems which, for some reason not explained, were omitted from all previous issues of the Household as well as from the Riverside Edition, - "An Impromptu at the Walcker Dinner," etc. (1863), "Hymn for the Great Central Fair in Philadelphia " (1864), "Harvard" (1880), "Youth" (1882), "Poem read at the Dinner given to the Author by the Medical Profession of New York City" (1883), ${ }^{1}$ and "But One Talent" (1890); (2) those poems which were written after the publication of the Riverside Edition, - "In Memory of John Greenleaf Whittier,"

${ }^{1}$ Added to the group of Medical Poems. 


\section{[ 160 ]}

"To the Teachers of America," "Hymn for the 25th Anniversary of the Reorganization of the Boston Y. M. C. U.," and "Francis Parkman;" and (3) a hitherto neglected bit from the "Autocrat," namely, the "Prelude" to "Parson Turell's Legacy," which, it will be remembered, was the only part of that poem which the Professor was allowed to read.

\section{POEMS, CABINET EDITION}

Complete Poetical Works. Cabinet Edition. Boston and New York, Houghton, Mifflin \& Co., 1899.

16mo, pp. xii, 453; portrait.

This edition contains everything that is included in the Cambridge Edition, except the head-notes and the last two divisions of the Appendix, namely, the Notes and Addenda, and the Chronological List.

\section{POEMS, LIBRARY EDITION}

The Complete | Poetical Works | of | Oliver Wendell Holmes | Library Edition | Illustrated with Photogravures | [Device]| Boston and New York|Houghton, Miffin \& Company | The Riverside Press, Cambridge | MDCCCC.

Printed from plates of the Household Edition, with additional half-titles (disregarded in pagination) before most of the groups of poems, and before the Notes and the Index. On the verso of each of the half-titles, with two exceptions, is a small cut. On page 88 (blank in the Household Edition) is the dedication of Songs in Many Keys, originally printed in the volume of that name. 
II

\section{PROSE}

\section{BOYLSTON PRIZE DISSERTATIONS}

Boylston | Prize Dissertations | For the Years 1836 and 1837. By Oliver Wendell Holmes, M. D., | Fellow of the Massachusetts Medical Society, and Member of the | Société Médicale d'Observation of Paris. | Boston: | Charles C. Little and James Brown. |

M. DCCC. XXXVIII.

$8 v o$, pp. xvi, 371 ; map. On p. v is the dedication: "To P. Cha. A. Louis, Doctor in Medicine of the Faculties of Paris and St. Petersburg, President of the Société Médicale d'Observation, etc., in the Recollection of his invaluable instruction and unvarying kindness, These Essays are respectfully inscribed." Pp. vii-ix, preface; xi-xiv [analytical] table of contents; 1-132, Facts and Traditions respecting the Existence of Indigenous Intermittent Fever in New England. Perseverando. 133-243, On the Nature and Treatment of Neuralgia. "Read not to contradict and confute, nor to believe and take for granted, nor to find talk and discourse, but to weigh and consider." 245-371, On the Utility and Importance of Direct Exploration in Medical Practice. Inter labores et taedia.

Each dissertation has its own half-title. 
HOMGEOPATHY,AND ITS KINDRED DELUSIO NS

Homcopathy, | AND its Kindred Delusions: | Two Lectures|delivered before the Boston Society for the | Diffusion of Useful Knowledge. | By Oliver Wendell Holmes, M. D. |

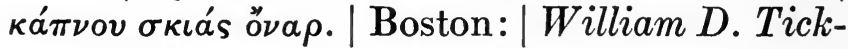
nor, | 1842.

Pamphlet, 12mo, pp. viii, 72. Preface on pp. iii-v, with 3 lines of errata at foot of p. $v$. First Lecture, pp. 1-27; Second Lecture, pp. 28-72. No headlines.

THE CONTAGIOUSNESS OF PUERPERAL FEVER

The | Contagiousness | of Puerperal Fever | by Oliver W. Holmes, M. D. | Read before the Society for Medical Improvement, and published at the Request of the Society. [1843.]

Pamphlet, 8vo, pp. 28.

Reprinted from the New England Quarterly Journal of Medicine and Surgery, April, 1843, vol. 1, pp. 503-530.

Puerperal Fever, | as a | Private PestiLence. | By | Oliver Wendell Holmes, M. D. | Parkman Professor of Anatomy and Physiology at Harvard University. | Boston:| Ticknor and Fields. | M DCCC LV.

Pamphlet, 8vo, pp. 60. On p. 3 is the dedication: "To the Medical Students and Graduates of Harvard University;" p. 4, "The Point at Issue;" pp. 5-24, introduction; pp. 25-60, "The Contagiousness of Puerperal Fever" (April, 1843). 
THE POSITION AND PROSPECTS OF THE MEDICAL STUDENT

The | Position and Prospects | of | the Medical Student.|An Address | delivered before the | Boylston Medical Society of Harvard University, | January 12, 1844, | by Oliver W. Holmes, M. D. | Published at the request of the Society. | Boston: | John Putnam, Printer | 1844.

Pamphlet, 8vo, pp. 28, including title.

REPORT OF THE COMMITTEE ON MEDICAL LITERATURE

Report of the Committee on Medical LitERATURE. (Extracted from the Transactions of the American Medical Association, vol. i.) [1847.]

Pamphlet, 8vo, pp. 40; slip attached with list of errata.

The report is signed (p. 40) by Dr. Holmes, Enoch Hale, G. C. Shattuck, Jr., D. Drake, John Bell, Austin Flint, and W. Selden.

\section{INTRODUCTORY LECTURE, 1847}

An | Introductory Lecture, | delivered at the | Massachusetts Medical College, | November 3, 1847. By Oliver Wendell Holmes, M. D. | Parkman Professor of Anatomy and Physiology. |[Device $]$ | Boston: | William D. Ticknor $\&$ Company, | corner of Washington and School Streets. | M DCCC XLVII.

Pamphlet, 8vo, pp. 38, with 1 blank leaf at 


\section{[ 164 ]}

end. Collation: 1, title; 2, copyright, and imprint (Printed by I. R. Butts, 2 School Street, Boston); 3, correspondence relative to printing the lecture; 4, blank; 5-38, lecture.

On the outside of the back cover is an advertisement of "medical books published by William D. Ticknor \& Co., Medical Booksellers."

\section{THE BENEFACTORS OF THE MEDICAL SCHOOL}

The | Benefactors | OF the | Medical School of Harvard University; | with a Biographical Sketch | of the | Late Dr. George Parkman. An | Introductory Lecture, | delivered at the | Massachusetts Medical College, | November 7, 1850, | by | Oliver Wendell Holmes, M. D. | Parkman Professor of Anatomy and Physiology.|Boston:| Ticknor, Reed, and Fields. | MDCCCL.

Pamphlet, 8vo, pp. 38, viz.: 1, title; 2, copyright and imprint; 3, correspondence with regard to printing the lecture; 4, blank; 5-37, lecture; 38, blank.

\section{ORATION BEFORE THE NEW ENGLAND SOCIETY}

Oration | Delivered before the New EngLAND SocIETY, | in the City of New York, | by Oliver Wendell Holmes, M. D., | at their Semi-centennial Anniversary, | December 22, 1855. [1856.]

Pamphlet, 8vo, pp. 48, including cover. 


\section{VALEDICTORY ADDRESS, 1858}

Valedictory Address, | delivered to the | Medical Graduates of Harvard University, | at the | Annual Commencement, | Wednesday, March 10, 1858. | By Oliver Wendell Holmes, M. D. | Parkman Professor of Anatomy and Physiology. | Re-printed from "The Boston Medical and Surgical Journal.”| Boston:| David Clapp ... 184 Washington Street.|Medical and Surgical Journal Office. | 1858.

Pamphlet, 8vo, pp. 15, including title.

\section{THE AUTOCRAT OF THE BREAKFAST- TABLE}

[For other editions see Appendix, pp. 312, 313, infra.]

The Autocrat [red]| of the | BreakfastTable. [red] | Every man his own Boswell. | Boston:| Phillips, Sampson and Company. [red]| M DCCC LVIII.

Crown 8vo, pp. viii, 373, 4 of advertisements ( 1 each at front and back and on inside of each cover), 4 blank pages in front and 5 at back. Plates; engraved title (not included in pagination) between the half-title and the title transcribed above. Collation: i, half-title; ii, blank; iii, title; iv, copyright, and imprint (Riverside, Cambridge: Stereotyped and Printed by H.O. Houghton and Company); v-viii, "The Autocrat's Autobiography," dated Nov. 1, 1858; 1-364, text; 365-373, index.

Motto on title printed in small type. Other copies of the same date have no engraved title, and are probably 


\section{[ 166 ]}

of a later issue. Another impression from the same plates was made in 1859. Of this issue some copies were printed on large paper, but none of the first issue are known to have been so printed. In later impressions the imprint was omitted from the copyright page, and the motto on the title-page printed in small capitals.

The original manuscript of the "Autocrat" is in the collection of J. P. Morgan, Esq.

The Same. By Oliver Wendell Holmes, Author of "Astræa" and other Poems. [Motto $\left.{ }^{1}\right]$ Edinburgh, Alexander Strahan \& Co.; London, Hamilton, Adams \& Co., 1859.

8vo, pp. 302.

The Same. London, Alexander Strahan, 148 Strand; Sampson Low, Son, \& Marston, Ludgate Hill, 1865.

8vo, pp. 200.

The Same. Boston, Ticknor and Fields, 1865. 32mo, pp. vi, 395; portrait. Pp. iii-vi, "The Autocrat's Autobiography;" pp. 381-395, index, with separate half-title.

Blue and Gold Edition.

The Same. With illustrations by J. G. Thomson. London, Alexander Strahan, 56 Ludgate Hill, 1865.

8vo, pp. xii, 329.

The Same. With an Introduction by George A. Sala. London, Chatto and Windus, 1875.

1 "Aquí está encarrada el alma del licenciado Pedro Garcias."

Gil Blas. 


\section{[ 167 ]}

24mo, pp. iii-vi, 9-235, and 32 of advertisements at end. Introduction on pp. v-vi.

Dr. Holmes's preface and “The Autocrat's Autobiography" are omitted.

The Same. New and Revised Edition, with illustrative notes. Boston, Houghton, Miffin \& Co., 1883.

8vo, pp. x, 321; portrait, opposite title; copyright, 1858 and 1882. On pp. iii-v is a new preface: "To the Readers of the Autocrat of the Breakfast-Table," dated Beverly Farms, Aug. 29, 1882; pp. vii-ix, "The Autocrat's Autobiography;" x, blank.

The "illustrative notes" are foot-notes.

The Same. Author's Edition. Edinburgh, David Douglas, 1883.

2 vols., 12mo; vol. i, pp. 212; vol. ii, pp. 256.

This edition contains, besides the "new preface" of this year ("To the Readers of the Autocrat") and "The Autocrat's Autobiography," "An After-Breakfast Talk," printed in the Atlantic Monthly for January, 1883.

The Same. Stereotyped and printed, with the permission of the author, by the American Printing House for the Blind [Louisville, Ky.], 1885.

2 vols., 4to; printed in raised letters on one side of the leaf. Vol. i, pp. 1-144; vol. ii, pp. 145-261; including title in each case.

The Same. By Oliver Wendell Holmes, Author of " The Professor at the Breakfast-Table, ${ }^{1}$ and "The Poet at the Breakfast-Table." London,

1 Quotation marks omitted here. 


\section{[ 168 ]}

Walter Scott, 24, Warwick Lane. Toronto, W. J. Gage \& Co. [1889.]

$12 \mathrm{mo}$, pp. viii, 271 , and 8 of advertisements. “The Autocrat's Autobiography" on pp. v-vii.

Camelot Series, vol. 44.

The Same. Boston, Houghton, Mifflin \& Co. [c. 1889.]

2 vols., $16 \mathrm{mo}$; vol. i, pp. x, 1-203 (half-title omitted in pagination); vol. ii, pp. iv, 205-442. Title-pages set in Old English type, within decorative borders. In vol. $i$, the preface of 1882, "To the Readers," etc., occupies pp. iii-vi, and the "Autobiography," pp. vii-x. In vol. ii, the index occupies pp. 433-442.

Birthday Edition. Printed from new plates. The "Professor," the "Poet," and "Over the Teacups" were published in the same style, the whole under the title of "The Breakfast-Table Series." About 300 copies were bound uncut, with paper labels.

The Same. Boston, Houghton, Miffin \& Co., 1891.

Crown 8vo, pp. $\mathbf{x}, 321$; portrait; preface to the new edition, dated Beverly Farms, July 28, 1891, pp. viii-ix.

Riverside Edition, vol. i, printed from plates of the edition of 1883.

The Same. Boston and New York, Houghton, Miffin \& Co., 1892.

8 vo, pp. xiv, 321 ; portrait and many illustrations; list of illustrations, p. xiii.

Vol. i of the Standard Library Edition; printed from the same plates as the Riverside Edition. 


\section{[ 169 ]}

The Same. The Autocrat [red] | of the Breakfast-Table | by Oliver Wendell Holmes [red] | with Illustrations by | Howard Pyle | I [II] [red] [Device]|Boston and New York|Houghton, Miffin and Company|The Riverside Press, Cambridge | M DCCC XCIII.

2 vols., 8vo; pp. xvi, 218; vi, 219-474; the pagination is continued through the two volumes. Illustrated with photogravures, headand tail-pieces and numerous cuts. Collation of vol. $\mathrm{i}$ : v-vi, list of illustrations; vii-x, preface of 1882 ; $x$-xii, preface of 1891 ; xiii-xvi, "The Autocrat's Autobiography."'

Holiday Edition; printed from new plates. Issued in England with imprint of Gay and Bird.

The Same. Boston, Houghton, Miffin \& Co., 1895.

Riverside Literature Series, no. 81. Printed from the same plates as the Riverside Edition.

The Same. Boston, New York, and Chicago, Houghton, Mifflin \& Co., 1896.

12mo; portrait. Printed from the plates of the Riverside Edition, with new title-pages and notes. Panel advertisement of Dr. 'Holmes's works preceding frontispiece, and $32 \mathrm{pp}$. of advertisements at end.

Riverside School Library.

The Same. Boston and New York, Houghton, Miffin \& Co., 1898.

Crown 8vo; portrait.

Cambridge Classics. Printed from the same plates as the Riverside Edition. 


\section{[ 170 ]}

The Same. "Reprinted from theoriginal edition." Chicago, W. B. Conkey Co., 1900. $16 \mathrm{mo}$, pp. 341.

The Same. With an Introduction by Richard Burton. New York, Thomas Y. Crowell \& Co., 1900.

16mo, pp. 329. Rubricated half-title, with device.

The Same. Boston, Houghton, Mifflin \& Co., 1902.

\section{$16 \mathrm{mo}$.}

Handy Volume Edition. Printed from the plates of the Birthday Edition. The "new preface" written for the Riverside Edition is omitted.

The Same. With illustrations by H. M. Brock. London, J. M. Dent \& Co., 1902.

12mo, pp. xxii, 318; frontispiece and many full-page and text cuts. Title-page in blue and brown, inclosed in an ornamental design in brown; device in centre is a tea-set in blue.

An American edition of 500 copies was made from the same plates, bearing the imprint of Houghton, Mifflin \& Co., in addition to that of Dent. It also has a copyright page (vi), which is not in the English copies.

Reissued in London and Boston in 1906; in this issue the title is printed on the title-page, "Autocrat at the Breakfast-Table."

The Same. With an Introduction by Gilbert K. Chesterton. London, Blackie \& Son, $L^{d}$. [1904.]

$16 \mathrm{mo}, \mathrm{pp} . \mathrm{x}, 390$; portrait; title set in ornamental border; running heads printed in red 


\section{[ 171 ]}

throughout. Introduction, pp. iii-x; "The Autocrat's Autobiography," pp. 1-4; Notes; prepared by E. H. Blakeney, M. A., Trinity College, Cambridge, pp. 349-390.

\section{TRANSLATION}

Der Tisch-Despot. Von Oliver Wendell Holmes. Deutsch von L. Abenheim. Stuttgart, Verlag von Aug. Berth. Auerbach.

12mo, pp. 431.

The translation is preceded by an unsigned poem. There is no indication of the date of publication.

THE PROFESSOR AT THE BREAKFASTTABLE

The Professor | at the | Breakfast-Table; with the | Story of Iris. | By Oliver Wendell Holmes, | Author of "The Autocrat of the Breakfast-Table." | Boston: | Ticknor and Fields. | м DCCC Lx. [c. 1859.]

12mo, pp. iv, 410; index, pp. 405-410.

Some copies were printed on large paper, but such copies are very rare.

The Same. London, Sampson Low, Son, \& Co., 1860.

8vo, pp. 286.

The Same. London, John Camden Hotten.

12mo, pp. 252.

The only indication of the date is an advertisement of new books for 1872 at the back of the volume.

The Story of Iris. | By | Oliver Wendell Holmes. | Boston: | James R. Osgood and Com- 


\section{[172].}

pany, late Ticknor \& Fields, and Fields, Osgood \& Co. 1877.

32mo, pp. 108, and 4 of advertisements; also advertisements on inside of both covers and on leaves facing them.

The | Professor at a the Breakfast-Table; with | The Story of Iris. |[Device]|Boston:| Houghton, Osgood and Company. | The Riverside Press, Cambridge. 1880.

8 vo, pp. ii, 410. Panel advertisement opposite title; index, pp. 405-410.

Printed from plates of the first edition.

The Professor at the Breakfast-Table. Boston, Houghton, Mifflin \& Co., 1883.

12mo, pp. viii, 332. Preface to new edition, dated Nov., 1882, pp. v-vii; index, pp. 321332.

The Same. Author's Edition. Edinburgh, David Douglas, 1883.

2 vols., $12 \mathrm{mo}$, pp. 260 and 227.

Uniform with the "Autocrat" and "Poet."

The same publisher also issued in this year an edition in one volume, 8vo, pp. vi, 410 .

The Professor at the Breakfast-Table. with the Story of Iris. Authorized Edition. Bernhard Tauchnitz, 1883.

Leipzig, $12 \mathrm{mo}$, pp. 336.

Selections from | The Professor | at the | Breakfast-Table. | By | Oliver Wendell Holmes, | Author of "The Autocrat of the Breakfasttable." | Stereotyped and Printed | by the | 


\section{[ 173 ]}

American Printing House | for the Blind. | Louisville, Kentucky. | 1884.

Quarto of 156 leaves, printed in raised letters on one side only; pp. 1-78 are printed on alternate right-hand pages; pp. 79-156 are printed on the intervening pages turned the other way.

The Professor at the Breakfast-Table. London, Walter Scott, 1889.

$12 \mathrm{mo}$.

Camelot Series. Uniform with "Autocrat" and "Poet." The Same. Boston, Houghton, Miffin \& Co., 1890.

2 vols., crown 8vo; pagination continued through the two volumes. Title-pages set in Old English type, within decorative borders.

Birthday Edition; uniform with the "Autocrat" and the other volumes of the "Breakfast-Table Series." About 300 copies were bound uncut with paper labels.

The Professor | at | the Breakfast-Table | with The Story of Iris | by / Oliver Wendell Holmes | [Device] | Boston and New York | Houghton, Miffin and Company|The Riverside Press, Cambridge / M DCCCC XCI.

8vo, pp. $x, 332$. Collation is as follows: $i$, half-title; ii, blank; iii, title; iv, copyright; v-vii, preface to revised edition (Nov., 1882); viii-x, preface to new edition, dated Beverly Farms, Mass., June 18, 1891. Index on pp. 321-332.

Riverside Edition, vol. ii.

The Same. With illustrations. Boston, Houghton, Miffin \& Co., 1892.

Standard Library Edition, vol. ii. 


\section{[174]}

The Same. Boston and New York, Houghton, Miffin \& Co., 1898.

\section{Crown 8vo.}

Cambridge Classics. Printed from the plates of the Riverside Edition.

The Same. With illustrations by H. M. Brock. London, J. M. Dent \& Co., 1902.

12mo, pp. xvi, 320.

Uniform with the same publishers' "Autocrat." Reissued, in London and Boston, in 1906. See p. 170, supra.

The Same. With an Introduction by Richard Burton. New York, Thomas Y. Crowell \& Co., 1902.

The Same. Boston, Houghton, Miffin \& Co., 1902.

$16 \mathrm{mo}$.

Handy Volume Edition; printed from the plates of the Birthday Edition.

\section{CURRENTS AND COUNTER-CURRENTS} IN MEDICAL SCIENCE

Currents and Counter-Currents | In MediCal Science. |An | Address | delivered before the | Massachusetts Medical Society, | at the Annual Meeting, | May 30, 1860. | By Oliver Wendell Holmes, M. D. | [Motto $\left.{ }^{1}\right] \mid$ Boston: | Published by Ticknor and Fields. D. Clapp, Printer . . . Med. and Surg. Journal Office.| MDCCCLX.

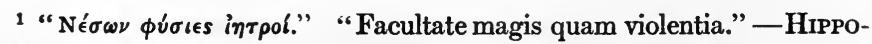
CRATES. 
8vo, pamphlet, pp. 56, viz.: 1, blank; 2, "Extract from the Records;" 1 3, title; 4, copyright; 5-43, address; 44, blank; 45-48, notes; $49-55$, list of deceased members and obituaries ; ${ }^{2}$ 56 , blank.

There are copies of the pamphlet containing only 48 pages, the list of deceased members and the obituaries being omitted.

Currents and Counter-Currents in MediCal Science. | With | Other Addresses and Essays. | By | Oliver Wendell Holmes, | Parkman Professor of Anatomy and Physiology in Harvard University, late Physician in the Massachusetts General Hospital, Member of the | Society for Medical Observation at Paris, - Fellow of the / Massachusetts Medical Society, Fellow of the | American Academy of Arts and Sciences. | Boston: | Ticknor and Fields. | MDCCCLXI.

8vo, pp. [ii], xii, 406, and 18 of advertisements. Collation: [i], title; [ii], copyright; i, dedication: "To James Jackson, M. D., my earliest medical teacher, whose friendship and counsel have been among the chief pleasures

1 At an adjourned meeting of the Fellows of the Massachusetts Medical Society, held on Thursday, May 31, $1860-$

"Some discussion ensued in regard to the Annual Address, when the following resolution, offered by Dr. H. H. Childs, of Pittsfield, was adopted by a vote of nine in the affirmative and seven in the negative:-

"Resolved, "That the Society disclaim all responsibility for the sentiments contained in this Annual Address.'

"A true copy,

1

"Attest: John B. Aluer

"Recording Secretary."

2 "The notices of Drs. Perry and Roby were written by the author of the foregoing Address. The sources of the others are indicated." 


\section{[ 176 ]}

and privileges of my life, these Essays are affectionately and respectfully dedicated;" ii, blank; iii-ix, preface; $x$, blank; xi, contents; xii, blank.

\section{Contents:-}

Currents and Counter-Currents in Medical Science, pp. 1-50. Homœopathy and its Kindred Delusions, pp. 51-177.

Some more Recent Views on Homœopathy. A Notice of the " Homœopathic Domestic Physician," pp. 179-188. First appeared in the Atlantic Monthly, Dec., 1857, vol. 1, pp. 250-252.

Puerperal Fever as a Private Pestilence. An Essay printed in 1843, reprinted with additions, 1855, pp. 189-278. First appeared in the New England Quarterly Journal of Medicine and Surgery, April, 1843, under the title "The Contagiousness of Puerperal Fever."

The Position and Prospects of the Medical Student, pp. 279321.

The Mechanism of Vital Actions, pp. 323-382. First appeared in the North American Review, July, 1857, vol. 75, pp. 39-77.

Valedictory Address, delivered to the Medical Graduates of Harvard University, at the Annual Commencement, Monday, March 10, 1858, pp. 383-406. First appeared in the Boston Medical and Surgical Journal, March 25, 1858, vol. 58, pp. 149-159.

There is a separate half-title to each essay.

See Medical Essays, infra, p. 189.

\section{ELSIE VENNER}

Elsie Venner:|A Romance of Destiny.|By Oliver Wendell Holmes, | Author of "The Autocrat of the Breakfast-Table," etc. | In Two Volumes. | Volume I. [II.] | Boston: Ticknor and Fields $\mid$ MDCCCLXI.

8vo; vol. i, pp. i-xii, 13-288; vol. ii, pp. i-iv, 5-312. Collation of vol. i: i, blank; ii, list of Dr. Holmes's works; iii, half-title; iv, blank; v, title; 


\section{[ 177 ]}

vi, copyright and imprint; vii, dedication, "To the Schoolmistress who has furnished some outlines made use of in these pages and elsewhere, this story is dedicated by her Oldest Scholar;" viii, blank; ix-x, preface, dated January, 1861; xi-xii, contents. Vol. ii has no half-title.

Originally appeared, under the title "The Professor's Story," in the Atlantic Monthly, January, 1860, to April, 1861.

The Same. Authorized Edition. Leipzig, Alphons Dürr, 1862.

8vo, pp. 380.

Elsie Venner. Boston, Houghton, Miffin \& Co., 1883.

12mo, pp. 487. On pp. vii-ix is "A Second Preface," dated Jan. 23, 1883.

The Same. Boston, Houghton, Miffin \& Co., 1891.

Crown 8vo, pp. xvi, 487; new preface, dated Beverly Farms, Aug. 3, 1891, pp. xii-xiii.

Riverside Edition, vol. v.

The Same. Boston, Houghton, Miffin \& Co. [1892.]

Illustrated with photogravures, etc. Standard Library Edition, vol. v.

The Same. London, Walter Scott, Limited, Paternoster Row. [1895?]

$8 \mathrm{vo}$, pp. 362 and 14 of advertisements; plate. Original preface on p. 5, and "Second Preface," dated Jan. 23, 1883, on pp. 7-8. Text begins on p. 11. 


\section{[ 178 ]}

The Same. Boston, Houghton, Mifflin \& Co., 1898.

Crown 8vo, pp. 487.

Cambridge Classics. Printed from plates of Riverside Edition.

\section{TRANSLATION}

E.-D. Forgues | Elsie Venner | La Sorcière à L'Ambre | Imitations de l'Anglais | [Device] | Paris $\mid$ Collection Hetzel $\mid$ - J. Hetzel - Librairie Claye - 18 Rue Jacob.

\section{$12 \mathrm{mo}, \mathrm{pp} .320$.}

The translation of Elsie Venner is on pp. 1-150.

A dramatization of Elsie Venner was attempted, against Dr. Holmes's wish, and a play founded on the novel was brought out in 1865, at the Boston Theatre. "The result was absolute failure." 1

\section{BORDER LINES OF KNOWLEDGE}

Border Lines of Knowledge | in some Provinces of $\mid$ Medical Science. | An Introductory Lecture, | delivered before the Medical Class of Harvard University, | November 6th, 1861. | By Oliver Wendell Holmes, M. D. | Parkman Professor of Anatomy and Physiology. | Boston: Ticknor and Fields, | 1862.

8vo, pp. ii, 80. Facing the title is an advertisement of Currents and Counter-Currents in Medical Science. Collation: i, title; ii, copyright; 1, correspondence; 2, blank; 3, "To the Reader;" 4, blank; 5-78, lecture; 79-80, "The Two Armies" [poem].

1 Morse's Life and Letters of O. W. H., vol. i, p. 257. 


\section{[179]}

\section{THE INEVTTABLE TRIAL}

Oratios| DelTVRed BefORE/THE CTT AtTHORIrIES OF Bostor, on the | Fourth of July, 1863, | by | Oliver Wendell Holmes. Boston, Ticknor and Fields. 1863.

Pamphlet, 8vo, pp. 60; riz.: 1, title; 2, imprint (Printed by J. E. Faruell and Comparsy, 37 Congress Street); 3, rote of thanks of the City Council; 4, blank; 5- $-\infty$, oration.

Sume copies bear on the title-page the imprint of J.E Farwell aod Co. Reprinted, under the title "The Inevitable Trial," in Pages from an Old Volume of Lifte, 1859.

The Save Private Copt. Boston, J. E. Farwell and Com paryy, Printers, 37 Congress Street, 1863.

4to, Pp. riil, 71; riz: i, title; ii, blank; iii, introductory note; iv, blank; $\pi$, half-title, "Oration;" vi, blank; rii, "principel alterations in the Address as delivered and printed:" viii, blank; 1-71, oration.

The introductory pote is as follows:-

-The realer has before hio the fest dratt of the

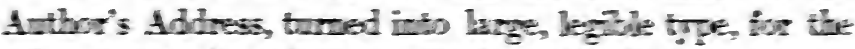
sole purpose of readering eaviez its pubbe delivery-

-It represeats, therefore, a rongh maenseript, withor: thase adfitions, on iswions aod euedatives, bo which

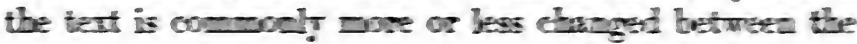
earibest copt aod the last revised peovt.

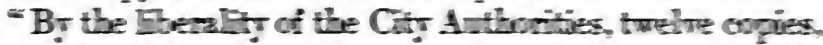
of which this is one, were privest, and placed at the anthor's disprsal No othens were strock of , with the exception of those which the printers were allowed to perserve as typographical speci-ueas " 


\section{[ 180 ]}

It is impossible to say how many copies were struck off for preservation by the printers. There are copies in existence which omit all reference to the number printed, and which show some variations in the text of the oration, although the same large type is used. In these copies there is a half-title, "Printed by order of the Common Council," the introductory note is omitted, and the oration is printed on pp. 5-75.

The Same. Philadelphia: Printẹd for Gratuitous Distribution, 1863.

Pamphlet, 8vo, pp. 30.

\section{LECTURE, 1863}

LECTURE, 1863.

See Appendix, p. 311, infra.

NEW ENGLAND'S MASTER-KEY

New England's Master-Key, 1864.

See Appendix, p. 312, infra.

\section{POETRY OF THE WAR}

LECTURE - 1865.

4to, pp. 54, unnumbered; signatures 1-14. No title-page.

The words "Lecture-1865" appear at the head of the first page. The covers are of blank paper and no author's name is given. But the Liberator for Dec. 15, 1865, published an abstract of the lecture as having been delivered at Music Hall, "in the course of Fraternity Lectures," by Dr. Holmes, "on Tuesday evening last." The pamphlet, which is printed in very large type (great primer), is exceedingly rare, only 2 copies being known. One of these, in perfect condition, with Dr. Holmes's autograph on the cover, is in the collection of Mr. S. H. Wakeman. 


\section{[ 181 ]}

\section{THE GUARDIAN ANGEL}

The | Guardian Angel. | By Oliver Wendell Holmes, | Author of "The Autocrat of the Breakfast-Table,"| "Elsie Venner," etc. | [Device]|Boston:| Ticknor and Fields. | 1867.

8vo, pp. xii, 420. Collation: i, title; ii, copyright and imprint; iii, dedication: "To James T. Fields, a token of kind regard from one of many writers who have found him a wise, faithful, and generous friend;" iv, blank; $v-x$, "To my Readers;" xi-xii, contents.

The Same. London, Sampson Low, Son, \& Marston, Milton House, Ludgate Hill, 1867.

2 vols., 12mo; vol. i, pp. xvi, 294, and 2 of advertisements; vol. ii, pp. viii, 302 , and 26 of advertisements, the first 2 unnumbered.

Reissued in 1869, in Low's Copyright Series of American Authors; the words "New Edition" being added to the title-page.

The Same. Boston, Houghton, Miffin \& Co., 1883.

Crown 8vo, pp. xvi, 431. New preface, dated 1883. Printed from new plates.

The Same. Boston, Houghton, Miffin \& Co., 1891.

Crown 8vo, pp. xvi, 431. New preface, dated Beverly Farms, Aug. 7, 1891.

Riverside Edition, vol. vi.

The Same. Boston, Houghton, Miffin \& Co. [1892.]

Illustrated with photogravures, etc. Standard Library Edition, vol. vi. 


\section{[ 182 ]}

TEACHING FROM THE CHAIR AND AT THE BEDSIDE

Teaching from the Chair and at the BEDside. | An | Introductory Lecture | delivered before the / Medical Class of Harvard University, | November 6, 1867. | By Oliver Wendell Holmes, | Parkman Professor of Anatomy and Physiology. | Printed at the request of the Class. | Boston: | David Clapp \& Son - 334 Washington Street. 1867.

Pamphlet, 8vo, pp. 46.

Reprinted in Medical Essays, 1883, under the title "Scholastic and Bedside Teaching."

\section{MEDICAL PROFESSION IN MASSACHUSETTS}

The | Medical Profession in MassachusetTs. | A Lecture | of a | Course by Members of the Massachusetts | Historical Society, | delivered before the Lowell Institute, | Jan. 29, 1869. | By | Oliver Wendell Holmes. | Boston: | Press of John Wilson and Son. | 1869.

Pamphlet, 8vo, pp. 45.

\section{HISTORY OF THE AMERICAN STEREOSCOPE}

History of the American Stereoscope. Joseph L. Bates, Boston. | Patented, Aug. 13, 1867. | From the Philadelphia Photographer, | January, 1869.

Pamphlet, 16mo, pp. 16, including title and 2 pp. of advertisements.

MECHANISM IN THOUGHT AND MORALS Mechanism | in | Thought and Morals. |An 
Address | delivered before the Phi Beta Kappa Society of | Harvard University, June 29, 1870. | With Notes and Afterthoughts | by | Oliver Wendell Holmes. | [Quotation from Pascal ${ }^{1}$ ] Boston | James R. Osgood \& Co. | Late Ticknor \& Fields, and Fields, Osgood, \& Co. $\mid 1871$. 8vo, pp. 101.

Reprinted in Pages from an Old Volume of Life, 1883.

\section{VALEDICTORY ADDRESS AT BELLEVUE HOSPITAL}

VAledictory Address delivered to the Graduating Class of the Bellevue Hospital College, March 2, 1871. New York, 1871.

Pamphlet, 8vo, pp. 23.

Reprinted from the New York Medical Journal, April, 1871, vol. 13, pp. 420-440. Included in Medical Essays, 1883, under the title "The Young Practitioner."

\section{THE CLAIMS OF DENTISTRY}

The Claims of Dentistry.|An Address |delivered at the | Commencement Exercises | of the | Dental Department $\mid$ in Harvard University, | February 14, 1872, | by Oliver Wendell Holmes, M. D., | Parkman Professor of Anatomy. | Boston: | Printed by Rand, Avery \& Co. | 1872.

Pamphlet, 8vo, pp. 36.

\section{THE POET AT THE BREAKFAST-TABLE}

The | Poet | at | the Breakfast-Table. | He Talks with his Fellow-Boarders | and the Reader. | [Device] | Boston: | James R. Osgood

1 Car il ne faut pas se méconnaître, nous sommes automates autant qu'esprit. 
and Company, | late Ticknor \& Fields, and Fields, Osgood, \& Co. 1872.

12mo, pp. ii, 418; frontispiece (the "Old Gambrel-Roofed House”); index on pp. 413418.

The Same. Boston, Houghton, Miffin \& Co., 1883.

12mo, pp. iv, 360; preface dated Dec., 1882.

The Same. Author's Edition. Edinburgh, David Douglas, Castle Street, 1884.

2 vols., 12mo, pp. 256, 267.

The Same. Boston, Houghton, Miffin \& Co., 1890.

2 vols., 16mo; titles set in Old English type, within decorative borders; pagination continued through the two volumes.

Birthday Edition. About 300 copies were bound uncut, with paper labels.

The Same. Boston, Houghton, Miffin \& Co., 1891.

8vo, pp. viii, 360 ; new preface, dated Beverly Farms, Aug. 1, 1891.

Riverside Edition, vol. iii.

The Same. Illustrated with photogravures, etc.

Standard Library Edition, vol. iii.

The Same. Boston, Houghton, Mifflin \& Co., 1902.

$16 \mathrm{mo}$.

Handy Volume Edition; printed from plates of Birthday Edition. 
The Same. With illustrations by H. M. Brock. London, J. M. Dent \& Co., 1902.

12mo, pp. xii, 351.

Uniform with the same publishers' "Autocrat." Reissued in London and Boston, in 1906. See p. 170, supra.

\section{PROFESSOR JEFFRIES WYMAN}

Professor Jeffries Wrman. | A Memorial Outline. | By Oliver Wendell Holmes. | Reprinted from the Atlantic Monthly for November, 1874.

Pamphlet, 8vo, pp. 16, including covers.

\section{CRIME AND AUTOMATISM}

Crime and Automatism. By Oliver Wendell Holmes.

Pamphlet, 8vo, pp. 16; n. p., n. d.

Reprinted from the Atlantic Monthly, April, 1875.

ADDRESS BEFORE THE BOSTON MICROSCOPICAL SOCIETY

An Address | Delivered at the | Annual Meeting of the Boston Microscopical SocIETy. | By | Oliver Wendell Holmes, M. D. | [Reprinted from the Boston Medical and Surgical Journal, May 24, 1877.]|Cambridge:|

Printed at the Riverside Press. | 1877.

Pamphlet, 8vo.

\section{JOHN LOTHROP MOTLEY}

John Lothrop Motley. | A Memoir. | By Oliver Wendell Holmes. | [Device $] \mid$ Boston: | Houghton, Osgood and Company. | The Riverside Press, Cambridge.| 1879. [c. 1878.] 


\section{[ 186 ]}

Crown 8vo, pp. viii, 278; portrait. Collation: i, title; ii, copyright, and imprint [Electrotyped and printed at the University Press, Cambridge]; iii, introductory note; iv, blank; v-vii, contents; viii, blank; 1-224, text; 225-278, appendices.

Issued also on large paper. The introductory note is as follows:-

"The Memoir here given to the public is based on a biographical sketch prepared by the writer at the request of the Massachusetts Historical Society, for its Proceedings. The questions involving controversies into which the Society could not feel called to enter are treated at considerable length in the following pages. Many details are also given which would have carried the paper written for the Society beyond the customary limits of such tributes to the memory of its deceased members. It is still but an outline which may serve a present need, and perhaps be of some assistance to a future biographer."

The appendices include: (a) An account of the Saturday Club, with Dr. Holmes's poem, "A Parting Health" (pp. 226-228); and (e) Proceedings of the Mass. Hist. Soc., June 14, 1877, including Dr. Holmes's remarks (pp. 257-269).

\section{LETTER TO RABELAIS CLUB}

Letter to the Honorary Secretaries of the Rabelais Club.

Broadside, pp. 4, on tinted paper; pp. 1 and 4, blank.

“For Private Circulation only."

\section{Gentlemen:}

Boston, March 21st, 1880.

It gives me great pleasure to accept the honour you have conferred upon me in choosing me as a member of the Rabelais Club. 


\section{[ 187 ]}

I assure you it is very pleasant to receive such a kindly token of recognition from a Society of gentlemen whose names are so distinguished in the lists of artists and men of letters. When we get the Sub-Atlantic Telephone I hope to exchange a few words with you all. I ought to say to the Club that I have a special professional interest in its patron-Saint.

In the year 1835, coming from Marseilles to Paris, I was delayed a short time in Lyons, and strayed into a little mouse-hole of an old book shop. There I picked up two or three bouquins, one of which was a pudgy little volume just exactly as tall as the breadth of this paper.

The title was

\section{APHORISMO.}

The bookbinder, probably a teetotaller, left out the RUM in lettering the back. The title page runs thus:

Aphorismo
Rum Hippocrates
SeCtiones
Septem.
$*$
Ex Franc. Rabel.eSI
Recognitione
$*$ * * *
Apud Seb. GrY-
PhiUM LU-
GDINI
1545.

I will borrow from the dedicatory epistle prefixed by my learned professional brother, Dr. Francis Rabelais, to this edition of the Aphorisms of the Father of Medicine, a few words expressing my good wishes for the Club.

Utinam ita floreat hæc Societas ut in ea nostrates episcopi et omnes alii absolutissimum probitatis, modestiæ, humanitatis exemplar, veramque illum virtutis ideam habeant, in quam contuentes aut ad propositum sibi speculum se moresque suos componant aut (quod ait Persius) virtutem videant, intabescantque relicta.

$$
\begin{aligned}
& \text { I am, Gentlemen, } \\
& \text { Faithfully yours, }
\end{aligned}
$$

Oliver Wendelu Holmes. 


\section{JONATHAN EDWARDS}

Jonathan Edwards.|An Essay. / From the International Review.) |A. S. Barnes \& Company. | New York and Chicago. [1880.]

Pamphlet, sq. 8vo, pp. 28.

Reprinted in Pages from an Old Volume of Life, 1883.

\section{DEDICATORY ADDRESS - BOSTON MEDICAL} LIBRARY ASSOCIATION

Dedicatory Address at the Dedication of the New Building and Hall of the Boston Medical Library Association, 19 Boylston St., Dec. 3, 1878. Cambridge, 1881.

Pamphlet, 4to, pp. 21.

Reprinted, under the title "Medical Libraries," in Medical Essays, 1883.

\section{MEDICAL HIGHWAYS AND BY-WAYS}

Medical Highways and | By-Ways. |A Lecture $\mid$ delivered before the Students of the Medical | Department of Harvard University, | May 10, 1882. $\mid$ By $\mid$ Oliver Wendell Holmes, M. D., LL.D., | Parkman Professor of Anatomy. | [Reprinted from the Boston Medical and Surgical Journal.]|Cambridge:| Printed at the Riverside Press. | 1882.

Pamphlet, 12mo, pp. 32.

The Boston Medical Library Association owns the original ms. of this lecture, consisting of 36 quarto pages, with the title "Some Stepping-Stones and StumblingBlocks in the History of Medicine." The opening paragraph is different, and there are other trifling variations from the text as printed. 


\section{[ 189 ]}

\section{FAREWELL ADDRESS}

Farewell Address | of | Dr. Oliver Wendell Holmes | to the | Medical School of Harvard University, | Tuesday, November 28, 1882. | [Reprinted from the Boston. Medical and Surgical Journal of | December 7, 1882.] | Cambridge:| Printed at the Riverside Press. 1882.

Pamphlet, 12mo, pp. 24.

Reprinted, under the title "Some of my Early Teachers," in Medical Essays, 1883.

\section{MEDICAL ESSAYS}

Medical Essays | 1842-1882. | By | Oliver Wendell Holmes. | Boston, Houghton, Miffin \& Co., 1883.

8vo, pp. xii, 445. Collation: i, title; ii, copyright; iii, contents; iv, blank; $\mathrm{v}-\mathrm{x}$, preface to Currents and Counter-Currents in Medical Science, with Other Addresses and Essays, 1861, except the last paragraph; xi-xii, a "Second Preface," dated March 21, 1883.

\section{CoNTENTs:-}

Homœopathy and its Kindred Delusions, pp. 1-102.

The Contagiousness of Puerperal Fever, pp. 103-172.

Currents and Counter-Currents in Medical Science, pp. 173208.

Border Lines of Knowledge in Some Provinces of Medical Science, pp. 209-272.

Scholastic and Bedside Teaching, pp. 273-311.

The Medical Profession in Massachusetts, pp. 312-369.

The Young Practitioner, pp. 370-395.

Medical Libraries, pp. 396-419.

Some of my Early Teachers, pp. 420-440.

Appendix [Notes to Currents and Counter-Currents], pp. 441445. 


\section{$[190]$}

The Same. Boston, Houghton, Miffin \& Co., 1891.

Crown 8vo, pp. xviii, 445; new preface, dated Beverly Farms, Aug. 3, 1891, pp. xiiixvii.

Riverside Edition, vol. ix; printed from plates of first edition.

The Same. Boston, Houghton, Miffin \& Co. [1892.]

Illustrated with photogravures, etc. Standard Library Edition, vol. ix.

PAGES FROM AN OLD VOLUME OF LIFE

Pages from an Old Volume | of Life | A Collection of Essays | 1857-1881 | by |Oliver Wendell Holmes | [Device] | Boston | Houghton, Miffin and Company | New York: 11 East Seventeenth Street | The Riverside Press, Cambridge | 1883.

8 vo, pp. iv, 433 , and 16 of advertisements.

\section{Contents:-}

Bread and the Newspaper. Originally appeared in the Atlantic Monthly, Sept., 1861, vol. 8, pp. 346-352.

My Hunt after "the Captain." Originally appeared in the Atlantic Monthly, Dec., 1862, vol. 10, pp. 738-764.

The Inevitable Trial. Oration delivered before the City Authorities of Boston, July 4, 1863.

The Physiology of Walking. Originally appeared, under the title "The Human Wheel, its Spokes and Felloes," in the Atlantic Monthly, May, 1863, vol. 11, pp. 567-580.

The Seasons. Originally appeared in the Atlantic Almanac, 1868, pp. 2-13.

Talk concerning the Human Body and its Management. Originally appeared in the Atlantic Almanac, 1869, pp. 4758. 


\section{[ 191 ]}

Cinders from the Ashes. Originally appeared in the Atlantic . Monthly, Jan., 1869, vol. 23, pp. 115-123.

Mechanism in Thought and Morals. Phi Beta Kappa, Harvard, 1870.

The Physiology of Versification. Originally appeared in the Boston Medical and Surgical Journal, Jan. 7, 1875, vol. 92, pp. 6-9.

Crime and Automatism. Originally appeared in the Atlantic Monthly, April, 1875, vol. 35, pp. 466-481.

Jonathan Edwards. Originally appeared in the International Review, July, 1880, pp. 1-28.

The Pulpit and the Pew. Originally appeared in the North American Review, Feb., 1881, vol. 132, pp. 117-138.

The Same. Boston, Houghton, Mifflin \& Co., 1891.

Crown 8vo, pp. [ii], vi, 433; preface, dated Beverly Farms, Aug. 3, 1891.

Riverside Edition, vol. viii; printed from plates of first edition.

The Same. Boston, Houghton, Miffin \& Co. [1892.]

Illustrated with photogravures, etc. Standard Library Edition, vol. viii.

\section{RALPH WALDO EMERSON}

American Men of Letters. | RALPH WaLdo Emerson. | By | Oliver Wendell Holmes. | [Device] | Boston: | Houghton, Mifflin and Company. | New York: 11 East Seventeenth Street. | The Riverside Press, Cambridge. | 1885. [c. 1884.]

12mo, pp. [ii], xii, 441; portrait. Collation: [i], title; [ii], copyright and imprint; i, note; ii, blank; iii-viii, contents; ix-x, blank; xi, halftitle; xii, motto; 1-421, text; 422, blank; 423441 , index. 


\section{[ 192 ]}

On p. 350, first line, "eightieth" is erroneously printed for "seventy-ninth." 1

The Same. English Copyright Edition. London, Kegan Paul \& Co., 1885. 8vo, pp. viii, 441.

\section{A MORTAL ANTIPATHY}

A Mortal Antipathy|First Opening of $\mid$ The New Portfolio | by | Oliver Wendell Holmes | [Device] | Boston and New York Houghton, Mifflin and Company|The Riverside Press, Cambridge | 1885.

8 vo, pp. iv, 307 , and 13 of advertisements.

Originally appeared, under the title "The New Portfolio," in the Atlantic Monthly, Jan. to Dec., 1885.

See Appendix, p. 312, infra.

The Same. Boston, Houghton, Miffin \& Co., 1891.

Crown 8vo, pp. vi, 307; new preface, dated Beverly Farms, Aug., 1891.

Riverside Edition, vol. vii. Printed from plates of first edition.

The Same. Boston, Houghton, Miffin \& Co. [1892.]

Illustrated with photogravures, etc. Standard Library Edition, vol. vii.

\section{OUR HUNDRED DAYS IN EUROPE}

\section{Our Hundred Days | in Europe | by | Oliver} Wendell Holmes | [Device $] \mid$ Boston and New

1 In his Memoir of Emerson read before the Massachusetts Historical Society, June 11, 1885 (Proceedings, 2d series, vol. 2, p. 107), Rev. J. F. Clarke says of this work of Dr. Holmes: "It will, I think, be always regarded as one of the best biographies in the language." 


\section{[ 193 ]}

York|Houghton, Miffin and Company|The Riverside Press, Cambridge | 1887.

$8 \mathrm{vo}$, pp. vi, 329 , and 14 of advertisements. On p. iii is this dedication: "To my Daughter Amelia (Mrs. Turner Sargent), my Faithful and Devoted Companion, this Outline of our Summer Excursion is affectionately dedicated." Index, pp. 321-329.

The index is preceded by the following note: "There are various ways of reading a book. A few diligent persons read, mark, learn, and inwardly digest every page, sentence, word, syllable. Quick-witted students glance through a volume, and find in a few moments what it has which is likely to be of interest for them. Some run their eyes rapidly over the Index, when there is one, which is no more than every book worth printing is entitled to. Some are satisfied with the Table of Contents. Others find the Title-page as much as they want, and there are many books, the wall-flowers of book-shops and libraries, which we are content to read by the lettering on their backs, without calling them out from their places.

"The following Index, made for me under the direction of my publishers, frightened me, when I first looked at it, by its exhaustiveness and its extent. I struck out a few headings, altered a few others, and concluded to let it stand as a monument of industry and fidelity. But I must say that so long a tail to so small a kite is almost without a precedent in my literary experience."

Originally appeared in the Atlantic Monthly, July, 1886, March to Oct., 1887. The first, detached, installment, printed under the title "The New Portfolio - A Prospective Visit," fills 16 pages of the magazine, only a small fraction being used for the introductory chapter - "A Prospective Visit" - of the volume. 


\section{[ 194 ]}

The early issues of the first edition may readily be identified, as they contain an extraordinary error. In one of the paragraphs of "A Prospective Visit" reprinted in the published book, Dr. Holmes says (p. 14 of vol. 58 of the Atlantic): "Among the monuments [in Westminster Abbey], one to my namesake Rear Admiral C. H., a handsome young man standing by a cannon. He accompanied Wolfe in his expedition which resulted in the capture of Quebec. Dryden has immortalized him, in the Annus Mirabilis, as

" "the Achates of the General's fight." "

In a paper entitled "After Our Hundred Days," printed in the Atlantic for January, 1888 (vol. 61, pp. 127130), we find the following:-

'After the 'Hundred Days,' the story of which has been published in this magazine during the past year, the natural sequel would seem to be - Waterloo. I thought I had experienced that catastrophe when my attention was called to an anachronism of unusual dimensions in one of the early numbers. It is made all right in the more recent copies of the collected papers, but stands uncorrected in many of those first printed. . . .

"How was it possible for a writer with some half dozen academic gowns on his back, a member of the Historical Society and contributor to its annals, to have spoken of the companion of Wolfe in his victory at Quebec, in 1759, as having been commemorated in Dryden's Annus Mirabilis, which was published in 1667, nearly a century earlier? It could hardly be ignorance, - the pons asinorum is not long enough to stretch over such an interval."

As revised, the passage reads (p. 4): "Among the monuments, one to Rear Admiral Charles Holmes, a descendant, perhaps, of another namesake, immortalized by Dryden in the 'Annus Mirabilis' as

“' the Achates of the general's fight.' 
"He accompanied Wolfe in his expedition which resulted in the capture of Quebec."

Thus is afforded a certain means of identifying the first issue of "Our Hundred Days." The same article explains one or two other matters in this volume, but the explanations do not involve changes in the text.

The Same. London, Sampson Low, Marston, Searle, \& Rivington, Limited, St. Dunstan's House, Fetter Lane, Fleet Street, E. C., 1888.

Royal 8vo, pp. vi, 316 ; portrait. Collation: i, notice of limit of edition; ii, blank; iii, title; iv, "works by the same author;" $\mathrm{v}$, dedication; vi, blank; 1-307, text; 308-316, index.

Large paper edition, limited to 100 copies.

The Same. Boston, Houghton, Miffin \& Co., 1891.

8vo, pp. viii, 301; pp. 209-301, General Index.

Riverside Edition, vol. $x$; from new plates. The General Index covers this and the preceding nine volumes, that is, all the collected prose works except the Emerson and the Motley, which were subsequently printed together as vol. $x i$ of this edition.

The Same. Boston, Houghton, Miffin \& Co. [1892.]

Illustrated with photogravures, etc. Standard Library Edition, vol. x.

HENRY J. BIGELOW, M. D.

Tribute to the Memory of Henry J. BigeLow, M. D., read at the meeting of the Society for Medical Improvement, Nov. 4, 1890. Printed at the University Press, 1891.

Pamphlet, 8vo, pp. 15, including title. 


\section{[ 196 ]}

Reprinted from the Proceedings of the American Academy of Arts and Sciences, May 26, 1891, vol. 26, pp. 339-351.

The original ms. of this address is now among the treasures of the Boston Medical Library Association, presented by Dr. Albert N. Blodgett in 1903.

\section{OVER THE TEACUPS}

Over the Teacups | by | Oliver Wendell Holmes | Author of "The Autocrat of the BreakfastTable" | [Vignette] | Boston and New York | Houghton, Miffin and Company|The Riverside Press, Cambridge | 1891. [c. 1890.]

8vo, pp. 319.

On p. 3 is a prefatory note, giving the history of the Henry Flynt teapot, of which there is a representation on that page.

The text begins on p. 5, with some introductory matter explaining the fact that, while the first installment was published in the Atlantic Monthly in March, 1888, the second did not appear until Jan., 1890. The paragraph on p. 6 , which begins, "The readers who take up this volume," is the true beginning of the book, but there are some changes in the text as it appeared in the magazine. The first words in the latter are: "The readers of this magazine may recollect," etc., and several lines at the end of the first paragraph are omitted in the published volume. Passing over some slight changes in the way of revision of the text, the passage on pp. 18-20 of the volume, beginning, "I referred, when first reporting," etc., and ending with the italicized phrase, "but it did," does not occur in the magazine, where its place is taken by this brief paragraph only:-

"I have had a whole chapter of curious coincidences, some of which, strange as they were, it was impossible 
to believe were in any causal relation. The GrenvilleTudor case was the most picturesque among them; the Mary Salter case the most unlikely to happen. But I am afraid I have told them already, somewhere or other, and I will say nothing about them at this time."

The first lines of the next paragraph read in the Atlantic: "I could not keep my own personality out of this paper;" and the concluding paragraph of the chapter does not appear there.

At the beginning of the second chapter the Atlantic (Jan., 1890) reads: "I know that it is a hazardous experiment to return to these pages where in days long past I have found a generous welcome."

This first edition of Over the Teacups was issued in London in the same year, with the imprint of Sampson Low \& Co.

The Same. Boston, Houghton, Mifflin \& Co., 1891.

Crown 8vo, pp. [vi], ii, 5-319.

Riverside Edition, vol. iv; printed from the plates of the first edition.

The Same. Boston, Houghton, Mifflin \& Co. [1892.]

Illustrated with photogravures, etc. Standard Library Edition, vol. iv.

The Same. Boston, Houghton, Miffin \& Co., 1895.

2 vols., 16mo; title-pages set in Old English type, within decorative border; pagination continued through the two volumes.

Birthday Edition. Uniform with other volumes of "The Breakfast-Table Series." About 300 copies were bound uncut, with paper labels. 


\section{[ 198 ],}

The Same. Boston, Houghton, Mifflin \& Co., 1902.

$16 \mathrm{mo}$.

Handy Volume Edition. Printed from plates of Birthday Fdition.

\section{EMERSON - MOTLEY}

Ralph Waldo Emerson John Lothrop Motley | Two Memoirs | by | Oliver Wendell Holmes | [Device] | Boston and New York|Houghton, Mifflin and Company|The Riverside Press, Cambridge. [1892.]

8vo, pp. xiv, 542. Collation: i, half-title; ii, blank; iii, title; iv, copyright; v-xi, contents; xii, blank; xiii, half-title [R. W. E.]; xiv, note; 1-325, Ralph Waldo Emerson; 326, blank; 327, half-title [J. L. M.]; 328, note; 329-526, John Lothrop Motley; 527-542, index.

Riverside Edition, vol. xi. 300 copies printed on large paper. This volume was added in 1892.

The Same. Illustrated. Houghton, Miffin \& Co., 1892.

Standard Library Edition, vol. xi. The collation corresponds with the last, except that a list of illustrations, with verso blank (xiii-xiv), follows the contents, and the R. W. E. half-title and the note are on pp. xv and xvi.

\section{WHITTIER COMMEMORATION}

Letter to William H. Baldwin, Esq., read at the Whittier Commemoration at the Boston Young Men's Christian Union, Sunday, Oct. 16, 1892.

Broadside, pp. 4; pp. 1 and 4 blank. 


\section{[ 199 ]}

The following works, believed to be the only ones as to which Dr. Holmes performed the functions of editor, are placed here for convenience.

Principles of the Theory and Practice of Medicine. By Marshall Hall, M. D., F. R. S. L[ondon] and E[dinburgh]. First American Edition. Revised and much enlarged by Jacob Bigelow, M. D., and Oliver Wendell Holmes, M. D. Boston, Charles C. Little and James Brown, 1839.

8vo, pp. iv, 724.

Medical Directions written for Governor Winthrop by Ed: Stafford, of London, In 1643. With Notes, by O. W. Holmes, M. D. Reprinted from the Proceedings of the Massachusetts Historical Society. Boston: Printed by John Wilson and Son, 22, School Street, 1862.

Pamphlet, 8vo, pp. 23. 


\section{COLLECTED WORKS}

Riverside Edition.

13 vols., crown 8vo. With portraits, notes by Dr. Holmes, etc. Boston, Houghton, Miffin \& Co., 1891.

Vol. I. The Autocrat of the Breakfast-Table.

Vol. II. The Professor at the Breakfast-Table.

Vol. III. The Poet at the Breakfast-Table.

Vol. IV. Over the Teacups.

Vol. V. Elsie Venner.

Vol. VI. The Guardian Angel.

Vol. VII. A Mortal Antipathy.

Vol. VIII. Pages from an Old Volume of Life.

Vol. IX. Medical Essays.

Vol. X. Our Hundred Days in Europe.

Vol. XI-XIII. Poems.

In 1892 the Memoir of Motley and the Emerson were printed together, and the volume was added to the Riverside Edition as vol. xi, the numbers of the three volumes of poems being changed to xii, xiii, and xiv.

Three hundred copies of this edition were printed on large paper, and numbered.

Issued in England with imprint of Sampson Low \& Co.

Standard Library Edition.

13 vols., 8vo. More than 100 photogravures and engravings on steel. Boston, Houghton, Miffin \& Co., 1892.

Printed from the plates of the Riverside Edition. The contents of the different volumes are the same, except that the poems occupy only two volumes, xii and xiii. Vol. xii contains the poems included in vol. xi and the 


\section{[ 201 ]}

first 158 pages of vol. xii of the Riverside Edition. After the publication of Mr. Morse's Life and Letters of O. W. H., those two volumes were added to the Standard Library Edition as vols. xiv and xv.

Artists' Edition.

13 vols., 8vo. Illustrated. Boston, Houghton, Mifflin \& Co. [1892-1896.]

Limited to 750 copies. Plates of the Standard Library Edition printed on India paper and mounted.

Popular Edition.

8 vols., crown 8vo. Boston and New York, Houghton, Mifflin \& Co. [1900.]

Vol. I. The Autocrat of the Breakfast-Table.

Vol. II. The Professor at the Breakfast-Table.

Vol. III. The Poet at the Breakfast-Table.

Vol. IV. Over the Teacups.

Vol. V. Elsie Venner.

Vol. VI. The Guardian Anget.

Vol. VII. A Mortal Antipathy.

Vol. VIII. Poems.

Printed from the plates of the Riverside Edition, except the last volume (Poems), which is identical with the latest issue of the Household Edition. The volumes are not numbered except in the publishers' catalogues.

Autocrat Edition. The Complete Writings of Oliver Wendell Holmes, with Introductory and Explanatory Notes. Boston and New York, Houghton, Miffin \& Co., 1904.

13 vols., crown 8vo; uniform in contents with the Standard Library Edition. Illustrated with 78 full-page photogravures, a complete series of portraits of Dr. Holmes, etc.

The illustrations are in great measure new. The edition is one of a "New Library Series." 


\section{SELECTIONS AND COMPILA'TIONS}

\section{The Collegian | in Six Numbers | Cambridge: |}

Published by Hilliard and Brown. | M DCCC Xxx.

The poems which Dr. Holmes contributed to this publication are given in the list printed below. Those preceded by an asterisk have never been printed in any of the collections of his poems; those preceded by a dagger were printed in the collections of 1836 and 1849, in the Blue and Gold Edition of 1862, and in the Handy Volume Edition, 1881, but were omitted from the Household Edition, and from all subsequent collections prior to the Cambridge Edition of 1895 .

The Collegian is almost invariably found in the shape of a bound volume; the compiler has been unable to place a set of the original numbers, although he is informed that such sets are in existence.

No. 1. February, 1830.

* Runaway Ballads, I and II, pp. 11-12.

The Toad-Stool, pp. 23-24.

* An Enigma, p. 43.

No. 2. March, 1830.

† The Last Prophecy of Cassandra, pp. 55-56.

* Romance, p. 60.

* Scene from an Unpublished Play, pp. 61-62.

No. 3. April, 1830.

To a Caged Lion, p. 103.

The Cannibal, pp. 103-106.

$\dagger$ To my Companions, pp. 122-123.

The Dorchester Giant, pp. 123-125.

* Scene from an Unpublished Play, pp. 138-140.

No. 4. May, 1830.

The Spectre Pig, pp. 180-182.

Reflections of a Proud Pedestrian, p. 199.

* An Invocation, pp. 199-200. 
No. 5. June, 1830.

The Mysterious Visiter, pp. 212-214.

The Meeting of the Dryads, pp. 221-223.

No. 6. July, 1830.

Evening, by a Tailor, pp. 255-256.

* Octosyllabics, pp. 261-263.

* Scene from an Unpublished Play, pp. 265-268.

Stanzas, p. 268.

* Moonshine, p. 277.

* The Old Gentleman's Story, pp. 277-279.

* The Graduate's Song, p. 282.

The Height of the Ridiculous, pp. 285-286.

* The Tail-Piece, pp. 289-290.

In a note to the Proceedings of the Harvard Club of New York City at the dinner of February 21, 1878, to which Dr. Holmes contributed the two sonnets, "Christo et Ecclesire" and "Veritas," we find the following: "After the reading of Dr. Holmes's explanatory letter, the printed copies of the sonnets were distributed among the guests. The magazine referred to in the letter was the Collegian, a journal published by the undergraduates of the Classes of 1830 and 1831 . It was edited by a Club consisting of William H. Simmons ('Luke Lockfast'), Robert Habersham ('Frank Airy'), Frederick W. Brune ('Arthur Templeton'), of the Class of 1831; and of Theodore W. Snow ('Geoffrey La Touche') and John O. Sargent ('Charles Sherry' and 'Francis Hock') of the Class of 1830. Oliver Wendell Holmes, of the Class of 1829, an honorary member of the Club, was then a law-student at Cambridge, and contributed one or more poems to every number of the magazine; beginning with his 'Runaway Ballads,' and concluding with a ' $L$ 'Envoi' [sic] that is among the most charming productions of his pen, though it has never, we think, appeared among his collected poems. ${ }^{1}$ We should not omit to mention that in the Collegian is to be found the first printed composition of John Lothrop Motley, of the Class of 1832."

None of Dr. Holmes's poems are signed, but a note to the table of contents says that all the titles marked with an asterisk are by the same contributor, so that the identification is not difficult. Dr. Holmes tells of his connection with this "little

' It will be found in full, under its proper title, "The Tail-Piece," supra, pp. 75-77. 


\section{[204]}

monthly concern" in a letter to Phineas Barnes, printed in Mr. Morse's Life and Letters, on pp. 67-69 of vol. i.

In the Harvard Magazine for Jan., 1858 (vol. 4, pp. 6-8), there is an interesting history of the Collegian, in an article on "College Magazines."

The | Amateur |A Journal of Literature and the Fine Arts | Edited by Frederick S. Hill Vol. 1.|Boston. | Published at the Office of the New England Galaxy. 1830.

\section{Engraved title-page.}

Contains the following poems by Dr. Holmes, an asterisk marking those which have not found a place in any of the collected editions of his poems.

No. 1. June 15, 1830.

Annual Exhibition of Paintings.

* The Fish-Pieces, pp. 12-13.

* The Idle Boys, p. 13.

* The Gipsy, p. 13.

The Athencum Gallery.

* The Departure, p. 16.

* Portrait of a Lady, p. 16.

* Lady Drinking, p. 16.

No. 2. July 3, 1830.

From a Bachelor's Private Journal, p. 22.

The Athenæum Gallery.

* Sunset Scene, p. 24.

Poultry, ${ }^{1}$ p. 24.

No. 3. July 17, 1830.

The Ballad of the Oysterman, pp. 37-38.

To a Blank Sheet of Paper, pp. 39-40.

No. 4. Aug. 7, 1830.

* The Two Shadows, p. 59.

State Prison Melodies: ${ }^{2}$ The Treadmill Song, p. 59.

No. 6. Sept. 4, 1830.

* Poetry of Real Life: The Flies, p. 90.

${ }^{1}$ Printed in Poems, 1836, and subsequent collections, under the title

“A Noontide Lyric."

2 This portion of the title was never used again. 


\section{[205]}

* Domestic Thoughts, p. 92.

* Infelix Senectus, p. 95.

No. 7. Oct. 1, 1830.

The Star and the Lily, ${ }^{1}$ p. 105.

* Song of the Henpecked, p. 116.

No. 16. March 12, 1831.

* To the Lady Opposite, p. 244.

No. 17. March 26, 1831.

The Last Leaf, p. 261.

No. 18. April 9, 1831.

Lines by a Very Interesting Young Man, ${ }^{2}$ p. 273.

* City Madrigals: by the Author of State Prison Melodies, p. 275.

No. 19. April 23, 1831.

* To my Neighbour Who Sings and Plays on the Flute, pp. 291-292.

* Scene from an Unpublished Comedy, p. 294.

This list includes eight poems which are found in all collected editions. As some of these eight are signed H., and others O.W. H., the compiler has attributed to Dr. Holmes all of those in the magazine which are signed in either way.

The Gleaner, or Selections in Prose and Poetry from the Periodical Press. Boston, Office of the New England Galaxy, 1830.

Contains the following poems by Dr. Holmes. This is, so far as is positively known, the first appearance of any work of his elsewhere than in periodicals. "Banditti," now known as "The Music-Grinders," had appeared in the New England Galaxy, "Evening" in the Collegian, and the others in the Amateur.

Banditti.

* The Two Shadows.

* Infelix Senectus.

Evening: by a Tailor.

The Treadmill Song.

${ }^{1}$ Printed in Poems, 1836, and subsequent collections, under the title "The Star and the Water-Lily."

${ }^{2}$ Printed in Poems, 1836, and subsequent collections, under the title "Lines by a Clerk." 


\section{[206]}

The | Laurel: |A Gift for all Seasons. | Being a | Collection of Poems | [Ornament] | by American Authors. | Boston:|Edward R. Broaders. | 1836. [c. 1835.]

Contains the following poems by Dr. Holmes, all of which had been published elsewhere. As, however, those preceded by an asterisk had previously appeared only in periodicals, they were first "collected" in this volume. The others had been printed in the Harbinger.

* To a Blank Sheet of Paper, pp. 23-25.

* Old Ironsides, pp. 41-42.

* The Last Prophecy of Cassandra, pp. 53-55.

From a Bachelor's Private Journal, pp. 65-66.

* To my Companions, pp. 95-97.

Stanzas, p. 99.

The Dilemma, ${ }^{1}$ pp. 102-104.

* The Star and the Lily, pp. 139-141.

The Dying Seneca, pp. 184-185.

The Last Leaf, pp. 202-203.

Poets and Poetry of America. By Rufus Wilmot Griswold. 1850.

Selections from Holmes's poems on pp. 360-368.

Chimes of Freedom and Union. Boston: Published by Benjamin B. Russell, 1861.

Contains the following poems of Dr. Holmes:-

Under the Washington Elm, p. 5.

Army Hymn, pp. 14-15.

Brother Jonathan's Lament for Sister Caroline, pp. 27-28.

A Voice of the Loyal North, p. 44.

This was the first publication elsewhere than in periodicals of all except the "Army Hymn."

Lyrics of Loyalty. Arranged and edited by Frank Moore. New York, George P. Putnam, 1864. [c. 1863.]

1 Spelled "Dillema" in contents. 
Contains the following poems of Dr. Holmes:-

The Flower of Liberty, pp. 116-117.

Trumpet Song, pp. 150-152.

Voyage of the Good Ship Union, pp. 184-188.

An Appeal ["Never or Now"], pp. 241-242.

The first and only appearance of the "Trumpet Song," and the first known appearance of "Never or Now."

Soundings from the Atlantic.| By / Oliver Wendell Holmes. | [Device]| Boston:| Ticknor and Fields. | 1864. [c. 1863.]

8vo, pp. viii, 468, and 22 of advertisements. Dedicated to Dr. Jacob Bigelow.

\section{Contents:-}

Bread and the Newspaper, pp. 1-23.

My Hunt after "The Captain," pp. 24-123.

The Stereoscope and the Stereograph, pp. 124-165.

Sun-Painting and Sun-Sculpture, pp. 166-227.

Doings of the Sunbeam, pp. 228-281.

The Human Wheel, its Spokes and Felloes, pp. 282-327.

A Visit to the Autocrat's Landlady, pp. 328-347.

A Visit to the Asylum for Aged and Decayed Punsters, pp. 348-361.

The Great Instrument, pp. 362-400.

The Inevitable Trial, ${ }^{1}$ pp. $401-468$.

For the original appearance of each of these articles in the Atlantic, see their respective titles in the alphabetical list (prose).

Verses from the Island Book. Cambridge: Printed at the Riverside Press, 1865.

Contains the following poems by Dr. Holmes:Prelude, p. iii.

Song ["Island Hunting-Song"].

Answer to an Invitation ["To Governor Swain"].

The Last Look.

The "Song" had previously been printed, under its longer title, in Poems, 1849, 2d issue, and "To Governor Swain"

${ }^{1}$ Oration delivered before the City Authorities of Boston, July 4, 1863. 


\section{[208]}

and "The Last Look," in Songs in Many Keys, 1862. The "Prelude" was written for this very rare volume, which contains many other poems written on or concerning Naushon Island; it has never been reprinted and is given in full herewith.

For Dr. Holmes's sentiments touching Naushon and its owners, see the Autocrat of the Breakfast-Table, Riverside Edition, pp. 39-41.

O Thou who lovest best the song Of bird that never sang in cage,

Such are the wood-notes that belong To this, our Island song-book's page!

O'er its fair field the fancy flits That never bounden book confined, And on its perch the warbler sits Whom leaden chains could never bind.

As when the birds in copse and glen,

From oaken bough and birchen spray, Thrush, robin, sparrow, bobolink, wren, Blackbird and bluebird, finch and jay, -

With joyous clamor wake the morn And startle all the leafy woods, To thrill these poet-voices, born In Nature's seagirt solitudes!

Ah, happy seasons, lapsing sweet Amid those bowers of peace and rest, When all the songsters loved to meet And carol round the King-bird's nest,

Your flowers are dust, your suns have set, Yet here they still shall bloom and shine, Till Love and Friendship both forget They knelt before the Island shrine!

November, 1864.

Humorous Poems. By Oliver Wendell Holmes. With Illustrations by Sol Eytinge, Jr. [Device] Boston: Ticknor and Fields. 1865. 24mo, paper, pp. 100 (i-iv, 5-100). 


\section{[209 ]}

Contents:-

The Ballad of the Oysterman.

To an Insect.

The Dilemma.

Daily Trials.

To the Portrait of "A Lady."

Reflections of a Proud Pedestrian.

The Dorchester Giant.

The Music-Grinders.

The September Gale.

The Toadstool.

The Spectre Pig.

The Treadmill Song.

My Aunt.

Lines recited at the Berkshire Festival.

Verses for After-Dinner.

Poem for the Centennial Celebration of Harvard College.

Evening: by a Tailor.

Nux Postcœnatica.

The Stethoscope Song.

On Lending a Punch-Bowl.

The Height of the Ridiculous.

Latter-Day Warnings.

Prologue [from the "Autocrat"].

The Deacon's Masterpiece.

The Old Man of the Sea.

Ode for a Social Gathering.

Parson Turell's Legacy.

Contentment.

De Sauty.

Astivation.

The Old Man Dreams.

What we all Think.

The Comet.

The Last Blossom.

"The Boys."

A Sea Dialogue.

The Jubilee.

The Sweet Little Man.

Our Oldest Friend.

Farewell to Agassiz. 


\section{[210]}

"The Jubilee," "A Sea Dialogue," and "A Farewell to Agassiz" had not previously appeared in any collection of Dr. Holmes's poems, and while the last two have never since been omitted, "The Jubilee," which, like "A Sea Dialogue," was originally written for The Boatswain's Whistle, published by the National Sailors' Fair during the war, has never appeared again.

Wit and Humour. Poems by the Autocrat of the Breakfast-Table. London, John Camden Hotten, Piccadilly, W., 1867.

$$
\text { 8vo, pp. } 192 .
$$

Contains an introduction by Mr. Hotten and the following poems:-

The Ballad of the Oysterman.

To an Insect.

The Dilemma.

Daily Trials.

To the Portrait of "A Lady."

Reflections of a Proud Pedestrian.

The Dorchester Giant.

The Music-Grinders.

The September Gale.

The Toadstool.

The Spectre Pig.

The Treadmill Song.

My Aunt.

Lines recited at the Berkshire Festival.

Verses for After Dinner.

A Song for the Centennial Celebration of Harvard College. Evening.

Nux Postcœnatica.

The Stethoscope Song.

On Lending a Punch-Bowl.

The Height of the Ridiculous.

Latter-Day Warnings.

Prologue.

The Deacon's Masterpiece

The Old Man of the Sea.

Ode for a Social Meeting. 


\section{[211 ]}

Parson Turell's Legacy.

Contentment.

De Sauty.

Estivation.

The Old Man Dreams.

What we all Think.

The Comet.

The Last Blossom.

"The Boys."

A Sea Dialogue.

The Jubilee.

The Sweet Little Man.

Our Oldest Friend.

A Farewell to Agassiz.

The Last Leaf.

The Mysterious Visitor.

Lines by a Clerk.

To the Portrait of "A Gentleman."

The Hot Season.

A Modest Request.

Parnassus, edited by Ralph Waldo Emerson, 1874.

Contains the following poems of Dr. Holmes, under the categories indicated:-

Heroic.

Old Ironsides.

Never or Now.

Personal.

To George Peabody.

Humorous.

The Deacon's Masterpiece.

Dorothy Q.

Contentment.

Rudolph the Headsman.

Favorite Poems. By Oliver Wendell Holmes. Illustrated. [Ornament] Boston: James $R$. Osgood and Company, late Ticknor \& Fields, and Fields, Osgood \& Co., 1877. 


\section{[212]}

32mo, pp. 105; plates; advertisements on inside of both covers, and on pages facing them.

Contents:-

Old Ironsides.

Our Yankee Girls.

The Last Leaf.

My Aunt.

Reflections of a Proud Pedestrian.

The Dorchester Giant.

The Comet.

The Ballad of the Oysterman.

The Music-Grinders.

The September Gale.

The Height of the Ridiculous.

The Hot Season.

The Steamboat.

Lines recited at the Berkshire Festival.

On Lending a Punch-Bowl.

The Stethoscope Song.

The Wonderful One-Hoss Shay.

Contentment.

The Old Man Dreams.

The Chambered Nautilus.

The Two Armies.

Musa.

The Two Streams.

Avis.

Dorothy Q.

Army Hymn.

International Ode.

Parting Hymn.

Holmes Leaflets. Poems and Prose Passages from the works of Oliver Wendell Holmes. For Reading and Recitations. Compiled by Josephine E. Hodgdon. Illustrated. Boston, Houghton, Miffin \& Co. [1881.]

8vo, pp. 107; with portrait and many other cuts. 


\section{[213]}

This volume is made up of poems and prose selections, each beginning on a right-hand page. On p. 11 "The Poet to the Children," Dr. Holmes's letter to the School Children of Cincinnati, Ohio, on their celebration of his seventy-first year. The prose selections are all taken from the Breakfast-Table Series.

Reissued in 1891 as extra number $\mathrm{H}$ of the Riverside Literature Series. The recent impressions, since Dr. Holmes's death, have contained a Biographical Sketch.

Grandmother's Story, and Other Poems, with Notes and a Biographical Sketch. Boston, Houghton, Miffin \& Co., 1883.

12mo, pp. 96; portrait, and cut of Holmes's Birthplace.

Riverside Literature Series, no. 6.

ConTENTs :-

Biographical Sketch [as in Poems, Household Edition].

Grandmother's Story.

How the Old Horse Won the Bet.

An Appeal for "The Old South."

A Ballad of the Boston Tea-Party.

The Ballad of the Oysterman.

Reflections of a Proud Pedestrian.

Evening: By a Tailor.

The Ploughman.

The Old Man of the Sea.

Dorothy Q: a Family Portrait.

Bill and Joe.

The Last Leaf.

Brother Jonathan's Lament for Sister Caroline.

For the Services in Memory of Abraham Lincoln.

Ode for Washington's Birthday.

Lexington.

Old Ironsides.

Robinson of Leyden.

The Pilgrim's Vision.

The Living Temple. 


\section{[214].}

The Chambered Nautilus.

Contentment.

The Two Armies.

Spring.

Centennial Celebration of Harvard College, 1836.

The Steamboat.

The Deacon's Masterpiece.

The Broomstick Train.

Under the Washington Elm, Cambridge.

Freedom, Our Queen.

The Flower of Liberty.

Union and Liberty.

God Save the Flag!

A Sun-Day Hymn.

Favorite Poems, and My Hunt after “the Captain." By Oliver Wendell Holmes. Boston, Houghton, Mifflin and Company. New York: 11 East Seventeenth Street. The Riverside Press, Cambridge, 1884.

32mo, pp. 307; with illustrations; advertisements of Modern Classics on inside covers and pages facing them.

Modern Classics, no. 30. The volume contains the following poems in addition to those printed in the Favorite Poems of 1877.

Lexington.

After a Lecture on Moore.

The Hudson.

Semi-centennial Celebration of the New England Society.

For the Meeting of the Burns Club.

Birthday of Daniel Webster.

Brother Jonathan's Lament for Sister Caroline.

Union and Liberty.

Robinson of Leyden.

Aunt Tabitha.

Bill and Joe.

The Boys. 


\section{[215]}

The Last Charge.

A Ballad of the Boston Tea-Party.

Never or Now.

Bryant's Seventieth Birthday.

At a Dinner to General Grant.

At a Dinner to Admiral Farragut.

To H. W. Longfellow.

For the Commemoration Services [Lincoln].

Edward Everett.

At the Atlantic Dinner.

Grandmother's Story of Bunker-Hill Battle.

How the Old Horse Won the Bet.

The poems fill 205 pages; "My Hunt after "the Captain", begins on p. 207, with a separate half-title.

Selections from the Breakfast-Table Series and Pages from an Old Volume of Life. By Oliver Wendell Holmes. Boston and New York, Houghton, Miffin \& Co. [1884.]

32mo, pp. 332; advertisements of Modern Classics on inside covers and pages facing them; index, pp. 331-332.

Modern Classics, no. 33.

\section{Contents:-}

Selections from the Autocrat.

Selections from the Professor.

Selections from the Poet.

The Physiology of Walking.

Cinders from the Ashes.

Illudstrated Poems of Oliver Wendell Holmes, with Illustrations by George Randolph Barse [and 19 others] [Device]. Boston, Houghton, Miffin and Company. New York: 11 East Seventeenth Street; The Riverside Press, Cambridge, 1885.

4to, pp. x, 89; portrait and numerous cuts. 


\section{[216].}

Collation: i, title; ii, copyright and imprint; iii, contents; iv, blank; v-viii, list of illustrations; ix-x, "Ave" [verse], dated Beverly Farms, July 24, 1884; 1-89, poems.

Contains 28 poems, all of which had appeared in some previous collection.

Issued in England with imprint of Macmillan \& Co.

Selections from the Poetical Works of Dr. Oliver Wendell Holmes. With a "Dedication," written by the Author expressly for this edition. Electrotyped. The Howe Memorial Press. Perkins Institution and Massachusetts School for the Blind. Boston. 1885. 4 to, pp. v, 168. Printed in raised letters for the use of the blind.

On page $v$ is the "Dedication" in verse, beginning:-

"Dear friends, left darkling in the long eclipse,"

to which no other title has ever been given than "Prelude to a Volume printed in Raised Letters for the Blind." The poems number 91.

The Same. The Howe Memorial Press. 1885.

4to. The same selections printed in raised symbols, not letters.

Poems. By Oliver Wendell Holmes. London, George Routledge \& Sons, Broadway, Ludgate Hill; New York, 9 Lafayette Place, 1886.

12mo, pp. 384.

Selected poems.

Selections from the Writings of Oliver Wendell Holmes, arranged under the Days of the Year, and accompanied by Memoranda of Anniversaries of Noted Events, and of the 
Birth or Death of Famous Men and Women. Boston and New York: Houghton, Miffin $\&$ Co. The Riverside Press, Cambridge, 1887. 24mo, pages unnumbered.

"The Chambered Nautilus" on leaf next title; selections begin on following leaf.

Half-Hours with the Best American AUTHORS. Selected and Arranged by Charles Morris. Philadelphia, J. B. Lippincott \& Co., 1887.

4 vols., 8vo.

Vol. i, pp. 487-493, Excerpts from the "Autocrat."

Vol. ii, pp. 434-435, "The Voiceless."

Vol. iii, pp. 130-132, "The Chambered Nautilus."

My Hunt after the Captain and Other PAPers. With Notes and an Introductory Essay. Boston, Houghton, Miffin \& Co., 1887.

\section{$12 \mathrm{mo}, \mathrm{pp} .93$.}

Riverside Literature Series, no. 31.

\section{Contents:-}

Dr. Holmes's Prose Writings.

My Hunt after the Captain.

The Physiology of Walking.

Great Trees (from the "Autocrat").

The Holmes Birthday Book [Ornament] [Quotation $^{1}$ [ [Device]. Boston and New York, Houghton, Mifflin and Company. The Riverside Press, Cambridge. [c. 1889.]

32mo, pp. [iv], 407; portrait and plates.

On p. [iii] is a passage from the "Poet," and the familiar portrait of Dorothy $Q$ is reproduced opposite p. 1 of

1 Four lines from "The Iron Gate." 


\section{[ 218 ]}

text. The selections for each month are preceded and followed by a poetical quotation. On the left-hand pages selections from Dr. Holmes's works are assigned to the days of the month, two to each page, and on the righthand pages the corresponding dates are repeated, with the names of famous persons who were born on those days, with the year of birth. Index of persons whose births are so recorded, on pp. 399-407.

Holmes Geins. Illustrated by Louis K. Harlow. Boston, Samuel E. Cassino, 196 Summer Street, 1891.

8vo. Rubricated title.

Warner's Library OF the World's Best Literature. Vol. XIII, pp. 7457-7495.

Old Ironsides.

The Last Leaf.

On Lending a Punch-Bowl.

The Chambered Nautilus.

The Deacon's Masterpiece.

A Sun-Day Hymn.

The Voiceless.

Bill and Joe.

Dorothy $\mathbf{Q}$.

The Three Professions (from the "Poet").

Elsie at the Sprowle Party (from Elsie Venner).

On Rattlesnake Ledge (from Elsie Venner).

My Last Walk with the School Mistress (from the "Autocrat").

The Lark on Salisbury Plain (from Our Hundred Days in Europe).

Holmes Year Book. London, Gay \& Bird, 1895.

The “Autocrat" Birthday Book. Being Selections from the Works of Oliver Wendell Holmes, arranged by A. L. McDonald. London, Sunday School Union. [1895.]

16mo, pp. 268. 
Selections from the Writings of Eleven American Authors, with Portraits and Biographical Sketches. Boston, Houghton, Mifflin and Co., 1896.

Riverside Literature Series, N. Holmes, pp. 30-36.

Contents:-

Biographical Sketch.

The Chambered Nautilus.

Robinson of Leyden.

Departed Days.

Grandmother's Story of Bunker Hill Battle and other Verse and Prose. Boston, Houghton, Miffin \& Co., 1896.

12mo, pp. 1-96, and 1-93, with panel advertisement preceding frontispiece and $32 \mathrm{pp}$. of advertisements at end; portrait and cut.

Published in Riverside School Library, and consists of Riverside Literature Series, nos. 6 and 31 (see pages 213 and 217), bound together; each part has a half-title, the second bearing these words: "My Hunt after the Captain and Other Papers, with an Introductory Essay on Dr. Holmes's Prose Writings."

The Wonderful "One-Hoss-Shay" (Reprinted from the Atlantic Monthly of September, 1858) and Other Poems. With numerous original illustrations by C. Moore Smith. New York, Frederick A. Stokes Company, 1897.

24mo, pp. 126.

Selected Poems by Oliver Wendell Holmes. With Introduction and Notes by E. H. Turpin. New York, Maynard, Merrill \& Co., 1898.

$16 \mathrm{mo}$.

Maynard's English Classic, Series, no. 205. Contains 


\section{[220].}

a biographical sketch of six pages, a "Chronology of Holmes's Chief Works," and "Critical Opinions," together with the following poems:-

Cambridge Churchyard.

Old Ironsides.

Our Yankee Girls.

Illustration of a Picture.

The Last Leaf.

To an Inser.t.

The Meeting of the Dryads.

The Comet.

The Ballad of the Oysterman.

Lexington.

The Music-Grinders.

The Height of the Ridiculous.

The Hot Season.

The Wasp and the Hornet.

"Qui Vive!"

Selections from Urania.

The Stereoscope and Stereoscopic PhotoGRAPHS. Oliver Wendell Holmes. Underwood and Underwood, New York, London, Ottawa (Kansas), and Toronto, 1898.

12mo, pp. 80.

CoNTENTS:-

Introduction.

The Stereoscope and the Stereograph; first appeared in Atlantic Monthly, June, 1859, vol. 3, pp. 738-748.

Sun-Painting and Sun-Sculpture; first appeared in Atlantic Monthly, July, 1861, vol. 8, pp. 13-19.

Article on Stereoscopic Photographs, signed Underwood and Underwood.

The One-Hoss Shay, The Chambered Nadtilus, and Other Poems, Gay and Grave. By Oliver Wendell Holmes. Boston and New York, Houghton, Miffin \& Co., 1899.

12mo, pp. viii, 154, and 1 of advertisement 


\section{[221 ]}

of the series; "Editor's Note," signed H. E. S[cudder] on pp. v-vi.

Riverside Aldine Classics.

Contents:-

The Deacon's Masterpiece, or the Wonderful "One-Hoss Shay."

Parson Turell's Legacy.

How the Old Horse Won the Bet.

The Broomstick Train.

My Aunt.

The Dorchester Giant.

The Height of the Ridiculous.

The Spectre Pig.

The Ballad of the Oysterman.

The Hot Season.

The Stethoscope Song.

Bill and Joe.

Latter-Day Warnings.

Contentment.

De Sauty.

Ode for a Social Meeting.

The Archbishop and Gil Blas.

Old Cambridge, July 3, 1875.

Epilogue to the Breakfast-Table Series.

The Chambered Nautilus.

Old Ironsides.

The Last Leaf.

The Cambridge Churchyard.

Dorothy $\mathbf{Q}$.

The Organ-Blower.

Agnes.

Avis.

A Sun-Day Hymn.

The Crooked Footpath.

Robinson of Leyden.

My Aviary.

A Ballad of the Boston Tea-Party.

Grandmother's Story of Bunker-Hill Battle.

The School-Boy.

At the Saturday Club.

The Iron Gate. 


\section{[222]}

The Early Poems of Oliver Wendell Holmes. With an Introduction by Nathan Haskell Dole. New York, T. Y. Crowell \& Co., 1899. $16 \mathrm{mo}$, pp. 325.

The Early Poems of Oliver Wendell Holmes. With a Biographical Sketch by Henry Ketcham. New York, A. L. Burt, 1900.

12mo, pp. 250.

Each of the two volumes last described contains all the poems, and no others, that were included in the London (Routledge) edition of 1852.

An American Anthology, E. C. Stedman, 1900.

Contains the following poems of Dr. Holmes:-

Old Ironsides.

The Last Leaf.

The Height of the Ridiculous.

La Grisette.

On Lending a Punch-Bowl.

After a Lecture on Keats.

The Voiceless.

The Living Temple.

The Chambered Nautilus.

Bill and Joe.

Under the Violets.

Hymn of Trust.

Epilogue to the Breakfast-Table Series.

Dorothy $\mathbf{Q}$.

Cacoëthes Scribendi.

The Strong Heroic Line. ${ }^{1}$

From "The Iron Gate."

Gems from Holmes. Boston, De Wolfe, Fiske \& Co., 1904.

16mo. Printed in pale blue and gold, with decorative borders.

1 Extract from the "Poem read at the Dinner given to the Author by the Medical Profession of the City of New York," April 12, 1883. 
The Chief American Poets, by Curtis Hidden Page. Boston and New York, Houghton, Miffin \& Co., 1895.

Contains the following poems of Dr. Holmes:-

Old Ironsides.

The Ballad of the Oysterman.

The Height of the Ridiculous.

To an Insect.

L'Inconnue.

My Aunt.

The Last Leaf.

La Grisette.

Our Yankee Girls.

On Lending a Punch-Bowl.

The Stethoscope Song.

The Statesman's Secret.

After a Lecture on Wordsworth.

After a Lecture on Shelley.

The Hudson.

To an English Friend.

The Old Man Dreams.

Birthday of Daniel Webster.

For the Meeting of the Burns Club.

Latter-Day Warnings.

The Chambered Nautilus.

The Living Temple.

The Deacon's Masterpiece.

Contentment.

Parson Turell's Legacy.

The Voiceless.

For the Burns Centennial Celebration.

The Boys.

At a Meeting of Friends.

The Two Streams.

Under the Violets.

Hymn of Trust.

A Sun-Day Hymn.

Prologue to Songs in Many Keys.

Brother Jonathan's Lament for Sister Caroline.

Parting Hymn. 


\section{[224]}

Union and Liberty.

J. D. R.

To my Readers.

Voyage of the Good Ship Union.

Bryant's Seventieth Birthday.

My Annual.

All Here.

Bill and Joe.

Nearing the Snow Line.

Dorothy Q.

Epilogue to the Breakfast-Table Series.

Programme.

Grandmother's Story of Bunker-Hill Battle.

How the Old Horse Won the Bet.

For Whittier's Seventieth Birthday.

Veritas.

The Silent Melody.

The Iron Gate.

The Shadows.

At the Saturday Club.

The Girdle of Friendship.

To James Russell Lowell.

The Lyre of Anacreon.

After the Curfew.

La Maison d'Or.

Too Young for Love.

The Broomstick Train.

Invita Minerva.

James Russell Lowell, 1819-1891.

In Memory of John Greenleaf Whittier. 


\section{[225]}

Selections from Dr. Holmes's works may be found also in the following collections:-

Cyclopedia of American Literature, edited by Evert A. and George L. Duyckinck. New York, 1856 ; also SupPLEMENT to same, 1866.

Golden Leaves from the American Poets, collected by John W. S. Hows. New York, 1864.

American Poems, 1879.

Biographical Sketch on pp. 317-319.

Modern American Lyrics, edited by Karl Knortz and Otto Dickmann. Leipzig and Boston, 1880.

Poems of American Patriotism, chosen by J. Brander Matthews. New York, 1882.

Library of American Literature, from the Earliest Settlement to the Present Time, edited by Edmund Clarence Stedman and Ellen Mackay Hutchinson. New York, 1888-1890.

Selections in vol. vii.

Representative Sonnets by American Poets, edited by Charles H. Crandall. Boston, 1890.

Masterpieces of American Literature, edited by Horace E. Scudder. Boston, 1891.

American Song, edited by Arthur B. Simonds, A. M. New York, 1894.

Poems of American Patriotism, 1776-1898, selected by R. L. Paget. Boston, 1898.

American Prose, edited by George Rice Carpenter. London and New York, 1898.

The Treasury of American Sacred Song. London and New York, 1900. 


\section{LETTERS}

Mr. Monse's biography of Dr. Holmes contains a large collection of his letters, including many to Mr. Motley, and a large proportion of those to Mr. Lowell, the originals of which have been deposited in the Harvard Library by Professor Norton as a part of his valuable collection of Lowell manuscripts. Mr. Morse has this to say in his preface on the general subject of Dr. Holmes's correspondence:-

"The fact is that letter-writing was to Dr. Holmes an irksome task. Except to Motley and to Lowell, during their absences in Europe, he very rarely wrote spontaneously and in the way of friendship. His letters, it will be observed, were almost always written because some correspondent could not be left unanswered, or under the more or less mild compulsion of some special occasion. Therefore his letters are few. Every effort has been made to collect them, and the result is spread very fully before the reader. Nothing has been omitted which, by any liberality of judgment, could be supposed to have any interest; on the contrary, notes and letters are printed, which would hardly have been selected had there been an embarras de richesses."

In chapter xii of the first volume of the Life and Letters ("The Victim of Correspondents"), Mr. Morse deals with the same subject at considerable length.

In connection with this chapter it is interesting to read what Dr. Holmes has to say in his own behalf. In an article in the Atlantic Monthly for January, 1886, called "A Cry from the Study," he writes somewhat bitterly concerning the correspondents who "could not be left unanswered."

"I am overburdened with a correspondence which I 
find almost unmanageable. It has reached such a point that $I$ feel as if it would not be unreasonable for me to put out a sign bearing my name with the following additions:- $* * *$ Professional Correspondent, attends to letters on all subjects, from all persons and all quarters. Autographs in quantity at short notice. The Correspondent will furnish stationery without charge to all applicants, in the form of envelopes addressed to himself, and stamped, containing a blank sheet of paper for the letter or message he is to receive. All communications, long or short, all manuscripts, legible or illegible, all books and pamphlets, readable or unreadable, thankfully received and immediately read and criticised. The Correspondent expects no pecuniary return for the few daily hours consumed in this labor of love. It is more than enough to be told that his well-known kindness and universally recognized genial nature have emboldened the writer to venture on what he (with superfluous modesty) calls his 'unauthorized intrusion.' The Correspondent would add that, if any sentence or any fragment of a sentence can be found in any letter of his which can be made use of so as to add commercial value to any publication, it cannot be expected that the word Private prefixed to that letter should be considered as preventing the recipient from giving it publicity in such form as may best promote his interests."

The details that he proceeds to give concerning the different varieties of letter to which he was subjected, and concerning his habit of replying to an enormously large proportion of them, leave little room for doubt that there must be an exceedingly large number of his letters in existence, and, at the same time, that, in many cases, they are not likely to be published.

On November 1. 1887, Dr. Holmes addressed to his correspondents a circular letter in these words:-

"Dr. Holmes regrets that impaired eyesight and the large demands made upon his time by distant and un- 


\section{[228]}

known friends oblige him to contract his hitherto extended correspondence, and to avail himself of the services of an assistant in writing."

Copies of this document, printed on a sheet of note paper, are rare and much sought after by collectors, especially when one of the blank pages bears, as is sometimes the case, an autograph letter from Dr. Holmes.

Letters on matters of public or quasi-public interest may be found in the following works. The list is of course very, very far from complete, and is offered simply for what it is worth. On a later page will be found some information concerning manuscript copies of certain letters which have found their way to the auction room.

Some Account of the Letheon, or Who is the Discoverer, 1847 , pp. 84-85.

A letter to Dr. W. T. G. Morton, suggesting "Anæsthesia" as a name to be applied to the state produced by his new discovery, and to the agent thereof. In a second edition of the same year Dr. Holmes's letter is on p. 79. In this edition the subtitle is changed to "Who was the Discoverer."

Report of Select Committee of House of Representatrves, U. S., on the Memorial of W. T. G. Morton; Thirty-Second Congress, 1st Session, 1852, p. 117.

An Account of the Pilgrim Celebration at Plymouth, Aug. 1, 1853, p. 136.

Dr. Holmes's letter, dated Pittsfield, July 5, 1853, concludes thus:-

"The good people of Delft, - They were known to all the rest of the world by their ugly mugs: but we shall always remember them for sending us a cargo of Chosen Vessels."

Celebration of the Centennial Anniversary of the Introduction of the Art of Printing into New Hampshire, in the City of Portsmouth, Oct. 6, 1856 (1857), pp. 54-55.

Trials of a Public Benefactor [Dr. W. T. G. Morton], by Nathan P. Rice, 1859, pp. 137, 286, 312, 429. 


\section{[229 ]}

Contains the letter to Dr. Morton, suggesting the name, "Anæsthesia," and three others relating to the Ether Controversy.

A History of the Boston Dispensary, 1859, pp. 138141.

Proceedings on Behalf of the Morton Testimonial, 1861.

Fifty-Eighth Anniversary Celebration of the New England Society in the City of New York, Dec. 22, 1863, pp. 45-47.

Our Daily Fare [see p. 36], June 17, 1864, no. 9, p. 65.

Letter written by Dr. Holmes in reply to a request of the Autograph Committee of the Great Western Fair at Cincinnati, in Dec., 1863, that he should be "funny over his own signature."

Boston, Dec. 14, 1863.

Dear Sir:- You ask me for a list of questions in Natural History, with answers subjoined, for the use of the instructor. I submit a few which, I think, will serve your purpose for the proposed examination of the Scientific Class:

1. What animal produces one of its own parents?

Answer. The beaver, which is well known to construct its own dam.

2. Is the Dodo extinct?

Ans. It is not, as shown by the following bill in my possession.

$\begin{array}{cr}\text { Mr. - to X-, } & \text { Dr. } \\ \text { One mongrel goose } & \$ 3.00 \\ \text { One do do } & \frac{3.00}{\$ 6.00}\end{array}$

3. What is the largest quadruped ?

Ans. The mole of Adrian.

4. What is the lightest quadruped?

Ans. The lynx. The lynx weighs less than an ounce.

5. When does a horse stand on six legs?

Ans. When he stands on his fore legs and his two hind legs also.

6. What other insect is the bee afraid of ?

Ans. The beetle - (scare-a-bee-us).

7. Is the otter of roses obtained from that animal when fed on other vegetables - cabbages for instance? 


\section{[230]}

Ans. Probably. The musk deer furnishes his perfume when fed on water melons.

8. What instance can you give of the cunning of serpents ?

Ans. The simple fact that they secrete their venom where they can find it when wanted.

9. Why do the above questions amuse you more than the answers?

Ans. Because the person who asks the questions is the querist.

As to the other questions about which you ask my opinion, my answer must be brief.

Eighteen hours' study out of twenty-four is too much, I think, for delicate young persons. It does not allow sufficient time for sleep, recreation and meals.

I doubt about the introduction of capital punishment as a part of the ordinary college discipline. It will have a good effect on the survivors, no doubt.

Oliver Wendell Holmes.

Fifty-Ninth Anniversary Celebration of the New Fngland Society in the City of New York, Dec. 15,1864 , p. 20.

Boston, Dec. 15, 1864.

DEAR Sir: - I regret very much that my engagements render it impossible for me to accept the very kind invitation of the New England Society to be present at their annual festival. May I take advantage of your kindness by requesting you to read the following advertisement, which $I$ hope will not fail to interest the children of the Pilgrims:-

\section{GREAT MORAL EXHIBITION \\ OF}

Architectural Models

TWO SHOWS UNDER ONE CANVAS

No. 1. Temple of Slavery - Foundation, trap rock; basement, serpentine, with corner stone of black lava; walls, loose conglomerate.

In the background - Vesuvius smoking.

No. 2. Temple of Liberty - Foundation, Plymouth granite; basement, Northern freestone; walls, Jasper, from the celebrated quarry of the New Jerusalem. 


\section{[231 ]}

Background - Mountains of New England.

Monadnock, Kearsarge, Wachusett.

Tickets free to all Mankind.

School children from the Old World monarchies and their masters are cordially invited.

\section{A. Lincoln, Manager.}

Ushers - Messrs. Grant, Sherman, Sheridan, Butler, Farragut, Winslow and others.

$N$. B. - This is the last opportunity to see the complete double show, as model No. 1 is shortly to be taken to pieces and removed to make room for an extension of the Temple of Freedom.

Yours, very truly and respectfully,

$$
\text { O. W. Holmes. }
$$

Sixty-Second Anniversary Celebration of the New England Society, Dec. 23, 1867, p. 63.

The New Ledger Building (Philadelphia), 1867, pp. 41-42.

Celebration of the One Hundred and Eleventh Anniversary of Robert Burns' Natal Day, at Delmonico's Hotel, New York, Jan. 25, 1870, pp. 10-11. Extracts from the same letter are printed in

Burnsiana: a Collection of Literary Odds and Ends relating to Robert Burns, compiled by John D. Ross (Paisley and London), 1892, vol. i, p. 72.

Proceedings of the Massachusetts Historical SociETY, Sept. 8, 1870, vol. 11, p. 369.

Letter on the death of John P. Kennedy.

The Unity of Italy. The American Celebration, etc., Jan. 12, 1871, p. 71.

Proceedings of the Massachusetts Historical SoCIETY, Aug. 10, 1871, vol. 12, pp. 154-155.

Letter concerning Sir Walter Scott. Also printed in

Tributes to Walter Scott on the 100th anniversary of his birthday, by the Mass. Hist. Soc., 1871, pp. 15-16; and in Quarterly Review, London, April, 1872. 


\section{[232]}

Proceedings at the Farewell Banquet to Prof. Tyndall, Feb. 4, 1873, pp. 25-27.

History of the Black Bear, "Billy Bruin," who escaped from Ridge Hill Farms, Wellesley, Mass., 1874, p. 15.

The Ark, Feb. 26, 1875, vol. 1, no. 5.

This periodical was conducted in the interest of a fair for the benefit of the Society for the Prevention of Cruelty to Animals. Dr. Holmes's letter is headed: "Suggestive Hints from Oliver Wendell Holmes." The concluding paragraph is as follows:-

"The Society must remember that even speaking animals have a right sometimes to plead for protection. Especially should the poets, or those who are commonly spoken of as such, be spared. The ascent of Parnassus is notoriously very diffcult, and I venture to recommend to the Society that it cause to be placed at the door of every building occupied by any association whatsoever, but more especially of every benevolent association, - inasmuch as all such feel that they have a right to call on everybody for everything, $-\mathbf{a}$ board with the following inscription:

"Please Spare your Poets when going up Hill."

Semi-Centennial of the Philomathean Society, Phillips Academy, Andover, Mass., May 26, 1875, pp. 73-75.

Laurel Leaves. Original Poems, Stories and Essays, 1876, p. vii.

The book is dedicated to Dr. Holmes, and the letter is his acceptance of the compliment.

Boston Medical and Surgical Journal, Sept. 28, 1876, vol. 95, pp. 393-395.

Letter concerning Dr. John B. S. Jackson.

Edgar Allan Poe. A Memorial Volume. By Sara S. Rice (Baltimore), 1877, pp. 79-80.

Guide to the Ridge Hill Farms, Wellesley, Mass., and Social Science Reform, 1877, pp. 55-56. 


\section{[ 233 ]}

Proceedings at a Reception in Honor of the Rev. O. B. Frothingham, by the Independent Liberal Club, April 22, 1879, p. 54.

City of Boston. Report of the Joint Special Committee on Intramural Interments, 1879.

Letter to the Committee, Sept. 1, 1879, in reference to interments in King's Chapel Burial-Ground.

Proceedings of the Two Hundred and Fiftieth Anniversary of the First Church and Parish of DorCHESTER, 1880, p. 170.

Boston Medical and Surgical Journal, June 23, 1881, vol. 104, p. 593.

Letter to Dr. George E. Ellis (Read at the Centennial Dinner of the Mass. Medical Society).

The Sword and the Pen, Dec. 10, 1881, no. 4, p. 1.

"A Note of Regret," dated Nov. 23, 1881. The paper was published in the interest of the Soldiers' Home Bazaar.

Proceedings at a Banquet given by his Friends to the Hon. Marshall P. Wilder, Ph. D., on his Birthday, Sept. 22, 1883, p. 101.

Herbert Spencer on the Americans and the AmeriCans on Herbert Spencer, 1883, pp. 84-85.

Critic, Sept. 6, 1884, n. s. vol. 2, p. 109.

"Dr. Holmes's Reply" to the "Surprise Party" number. See infra, pp. 268-269.

American Anti-Slavery Society Commemoration, 1884, p. 61.

Proceedings at the Presentation of a Portrait of J. G. Whittier to the Friends' School, Providence, R. I., 10th Mo., 24, 1884 (1885).

Letter dated July 16, 1884.

History of the Ordination of Caleb D. Bradlee. Also History of the 30th Anniversary of his Ordination, Dec. 11, 1854-Dec. 11, 1884.

Letter dated Nov. 28, 1884. 


\section{[234]}

Boston Medical and Surgical Journal, Feb. 12, 1885, vol. 112, pp. 165-166.

Letter to Dr. Fordyce Barker, on his resigning the office of President of the New York Academy of Medicine.

Proceedings of the Maine Historical Society on H. W. Longfellow's 78th Birthday, Feb. 27, 1885, pp. 21-22.

Proceedings of the Dedication of the Fountain in Faton Square, Ward 24, in Memory of Theodore LyMAN, JR., Oct. 26, 1885 (1886), p. 53.

Recreations of the Rabelais Club, 1882-1885.

Dr. Holmes's letter is printed as a sort of introduction to this second series of the "Recreations."

A Testimonial to Charles J. Paine and Edward Burgess from the City of Boston, for their successful defence of the America's cup, 1887, p. 151.

Correspondence of John Lothrop Motrey, edited by G. W. Curtis, 2 vols., 1889.

These volumes contain, besides many letters to Dr. Holmes from Mr. Motley, some eight or ten letters from him to Mr. Motley. See the Index. Also see pp. 21-22, supra. In a letter of Sept., 1863 (vol. ii, p. 141), Motley speaks in the warmest terms of Dr. Holmes's Fourth of July Oration.

Bulletin of the New York Public Library, Nov., 1890, vol. 4, pp. 356-357.

New York "Pseudo-Critics" in 1850. - A letter, never before published, written by Dr. Holmes to E. A. Duyckinck, Nov. 9, 1850, in reply to a criticism of "Astræa" in the Literary World for October of that year, attributed to Cornelius Matthews.

Bulletin of the Harvard Medical School AssociaTION, no. 1, 1891, pp. 30-32.

Abraham Coles: Biographical Sketch, Memorial Tributes, etc. (Jonathan A. Coles, editor), 1892, p. 46. 


\section{[235 ]}

Sermons and Addresses in Recognition of the Twentyfifth Anniversary of the Installation of the Rev. Alexander McKenzie. The First Church in Cambridge, 1892, pp. 57-58.

Bryant Centennial at Cummington, Aug. 16, 1894, pp. 47-48.

Daniel Roberts, of the Society of Friends. A Quaker of the Olden Time, being a memoir of John Roberts, etc. E. T. Lawrence, editor [London], 1898.

Prefatory letter by Dr. Holmes.

Passages from the Correspondence and Other Papers of Rufus Wilmot Griswold, 1898, p. 146.

See supra, p. 77.

Thoughts and Experiences in and out of School, by John B. Peaslee. Cincinnati, 1900, pp. 285, 287, 293, 301, 307, 329.

The Story of My Life. Helen A. Keller, 1903.

Letter to Miss Keller, dated Aug. 1, 1890.

Proceendings of the Massachusetts Historical SoCIETY, June 9, 1904, 2d series, vol. 18, pp. 346-347.

Letter to Dr. George E. Ellis, describing the peculiar case of one Mary Chase; letter dated June 3, 1881. 


\section{DR. HOLMES'S CONTRIBUTIONS TO THE ATLANTIC MONTHLY}

THE following list includes all of Dr. Holmes's contributions to the magazine with which he was, perhaps, more closely identified than any other person, although he was never its editor. The poems which were printed as parts of serials and of other prose articles are not listed.

It will be noted that of the first sixty volumes of the Atlantic, the only ones which contain nothing from his pen are volumes xviii, xxvi, xl, and xliii; and that, of the remaining thirteen volumes which appeared during his life (volume lxxiii ended in June, 1894, and Dr. Holmes died in October), he was a contributor to seven. Surely a most exceptional record. The last three contributions were called forth by the deaths of three of his contemporaries, one of whom, at least (the first editor of the Atlantic), was his very dear friend.

The story of the founding of the Atlantic has been told many times, and is sure to be told again, authoritatively, during the celebration of its fiftieth anniversary, in 1907. It is well known that Dr. Holmes christened the magazine. ${ }^{1}$ His connection with its founding was told by himself in the paper ("Dr. Holmes's Reminiscence") read by Mr. H. O. Houghton at the Holmes Breakfast in Dec., 1879 (vol. 45, supp.); also by Mr. Scudder in his James Russell Lowell, vol. i, p. 413, and by Mr. Morse in the Life and Letters of O. W. Holmes, vol. i, pp. $204 \mathrm{ff}$.

Volume I: Nov., 1857, to May, 1858.

The Autocrat of the Breakfast-Table, November to May.

The Homœopathic Domestic Physician [Review], December.

Agassiz's Natural History [Review], January.

Parthenia [Review], February.

Volome II: June to Dec., 1858.

Dr. Asa Gray's Botanical Series [Review], August.

The Autocrat of the Breakfast-Table, June to October.

${ }^{1}$ In the "Autocrat" (Riverside Edition, p. 55), he observes that the Atlantic " is not so called because it is a notion, as some dull wits wish they had said, but were too late." 


\section{[237 ]}

A Visit to the Autocrat's Landlady, November.

Brief Expositions of Rational Medicine [Review], November.

The Last Look, November.

The Autocrat gives a Breakfast to the Public, December.

Volome III: Jan. to June, 1859.

The Professor at the Breakfast-Table, January to June.

Mothers and Infants, Nurses and Nursing [Review], May.

The Stereoscope and the Stereograph, June.

Volume IV: July to Dec., 1859.

The Professor at the Breakfast-Table, July to December.

Love [Review], September.

Volume V: Jan. to June, 1860.

The Professor's Story [Elsie Venner], January to June.

The Undergraduate [Review], March.

Volume VI: July to Dec., 1860.

The Professor's Story [Elsie Venner], July to December.

Volume VII: Jan. to June, 1861.

The Professor's Story [Elsie Venner], January to April.

A Visit to the Asylum for Aged and Decayed Punsters, January.

Brother Jonathan's Lament for Sister Caroline, May.

Army Hymn, June.

Volume VIII: July to Dec., 1861.

Sun Painting and Sun Sculpture, July.

Parting Hymn, August.

Bread and the Newspaper, September.

The Wormwood Cordial of History, October.

The Flower of Liberty, November.

Union and Liberty, December.

Volume IX: Jan. to June, 1862.

Voyage of the Good Ship Union, March.

Volume X: July to Dec., 1862.

The Poet to the Readers, July.

My Hunt after the Captain, December.

Volume XI: Jan. to June, 1863.

Choose You this Day whom Ye will Serve, March.

The Human Wheel, its Spokes and Felloes, May. 


\section{[238]}

Volume XII: July to Dec., 1863.

Doings of the Sunbeam, July.

The Great Instrument, November.

Volume XIII: Jan. to June, 1864.

The Minister Plenipotentiary, January.

The Last Charge, February.

Our Classmate (F. W. C.), March.

Our Progressive Independence, April.

Shakespeare, June.

Volume XIV: July to Dec., 1864.

Hawthorne, July.

In Memory of J. W. - R. W., July.

Bryant's Seventieth Birthday, December.

Volume XV: Jan. to June, 1865.

God Save the Flag, January.

Our Oldest Friend, March.

Our First Citizen (Edward Everett), April.

Our Battle Laureate (H. H. Brownell), May.

Volume XVI: July to Dec., 1865.

No Time like the Old Time, October.

A Farewell to Agassiz, November.

Volume XVII: Jan. to June, 1866.

My Annual, April.

Volume XIX: Jan. to June, 1867.

The Guardian Angel, Jan. to June.

All Here, March.

Volume XX: July to Dec., 1867.

The Guardian Angel, July to December.

Chanson without Music, November.

Volume XXI: Jan. to June, 1868.

Once More, April.

Volume XXII: July to Dec., 1868.

Bill and Joe, September.

Volume XXIII: Jan. to June, 1869.

Cinders from the Ashes, January. 


\section{[239 ]}

Volume XXIV: July to Dec., 1869.

Bonaparte, August 15, 1769 - Humboldt, September 14, 1769, November.

Volume XXV: Jan. to June, 1870.

Nearing the Snow-Line, January.

Even-Song, March.

Volume XXVII: Jan. to June, 1871.

Dorothy Q., a Family Portrait, January.

Volume XXVIII: July to Dec., 1871.

Life of Major John André [Review], July.

Volume XXIX: Jan. to June, 1872.

The Poet at the Breakfast-Table, January to June.

Volume XXX: July to Dec., 1872.

The Poet at the Breakfast-Table, July to December.

Volume XXXI: Jan. to June, 1873.

After the Fire, January.

Volume XXXII: July to Dec., 1873.

The Fountain of Youth, August.

A Poem Served to Order, September.

Sex in Education [Review], December.

Volume XXXIII: Jan. to June, 1874.

An Old-Year Song, January.

A Ballad of the Boston Tea-Party, February.

Volume XXXIV: July to Dec., 1874.

Professor Jeffries Wyman, November.

Volume XXXV: Jan. to June, 1875.

The Americanized European, January.

Crime and Automatism, April.

Volume XXXVI: July to Dec., 1875.

Old Cambridge, August.

Exotics, September.

Volume XXXVII: Jan. to June, 1876.

A Familiar Letter (To Several Correspondents), January. "Ad Amicos," March.

A Memorial Tribute, April. 


\section{[240]}

Volume XXXVIII: July to Dec., 1876.

How the Old Horse Won the Bet, July.

Volume XXXIX: Jan. to June, 1877.

How Not to Settle It, February.

The First Fan, June.

Volume XLI: Jan. to June, 1878.

My Aviary, January.

Volume XLII: July to Dec., 1878.

The Silent Melody, September.

Volume XLIV: July to Dec., 1879.

Vestigia Quinque Retrorsum, August.

Volume XLV: Jan. to June, 1880.

The Coming Era, January.

The Iron Gate, Supplement.

Dr. Holmes's Reminiscence, Supplement.

Volume XLVI: July to Dec., 1880.

The Archbishop and Gil Blas, August.

Benjamin Peirce: Astronomer, Mathematician, December.

Volume XLVII: Jan. to June, 1881.

Boston to Florence, March.

Volume XLVIII: July to Dec., 1881.

Post Prandial, September.

Volume XLIX: Jan. to June, 1882.

Before the Curfew, March.

Our Dead Singer, June.

Volume L: July to Dec., 1882.

At the Summit, August.

Volume LI: Jan. to June, 1883.

An After-Breakfast Talk, January.

A Loving-Cup Song, March.

Pillow-Smoothing Authors, April.

The Flaneur, May.

Volume LII: July to Dec., 1883.

King's Chapel, September. 


\section{[241 ]}

Volume LIII: Jan. to June, 1884.

At the Saturday Club, January.

The Girdle of Friendship, March.

Thomas Gold Appleton, June.

Volume LIV: July to Dec., 1884.

Ave, October.

Volume LV: Jan. to June, 1885.

The New Portfolio (A Mortal Antipathy), January to June.

Volume LVI: July to Dec., 1885.

The New Portfolio (A Mortal Antipathy), July to December.

Two Anniversary After-Dinner Poems, August.

Volume LVII: Jan. to June, 1886.

The New Portfolio (A Cry from the Study), January.

The New Portfolio (Two Occasional Poems with an Interlude), March.

Volume LVIII: July to Dec., 1886.

The New Portfolio (A Prospective Visit), July.

Poem on the Two Hundred and Fiftieth Anniversary of the

Foundation of Harvard University, Supplement.

Volume LIX: Jan. to June, 1887.

Our Hundred Days in Europe, March to June.

Volume LX: July to Dec., 1887.

Our Hundred Days in Europe, July to October.

Volume LXI: Jan. to June, 1888.

After "Our Hundred Days," January.

Over the Teacups, March.

Volume LXIII: Jan. to June, 1889.

To James Russell Lowell, April.

Volume LXV: Jan. to June, 1890.

Over the Teacups, January to June.

Volume LXVI: July to Dec., 1890.

Over the Teacups, July to November.

But One Talent, December. 


\section{[242.]}

Volume LXVIII: July to Dec., 1891.

James Russell Lowell, October.

Volume LXX: July to Dec., 1892.

In Memory of John Greenleaf Whittier, November.

Yolume LXXIII: Jan. to June, 1894.

Francis Parkman, February. 


\section{BIOGRAPHY AND CRITICISM}

\section{I \\ BIOGRAPHIES}

Bald, James. Dr. Oliver Wendell Holmes and His Works: Being a Brief Biography and Critical Review. London, Elliot Stock, 62, Paternoster Row, 1878.

$16 \mathrm{mo}, \mathrm{pp} .199$.

Brown, Emma Eumzabeth. I ife of Oliver Wendell Holmes. Boston, D. Lothrop \& Co. [c. 1884.]

12mo, pp. 302; portrait.

On p. 302 (unnumbered) is a brief and valueless bibliography. The portrait is shocking and the whole book is atrocious from a mechanical standpoint.

Jerrold, Walter. Oliver Wendell Holmes. London, Swan Sonnenschein \& Co.; New York, Macmillan \& Co., 1893.

24mo, pp. vi, 144.

"The Iron Gate" is printed on pp. 139-142. On pp. 143-144 is a so-called bibliography, which is simply a list of the volumes of the Riverside Edition, with the contents of each. Throughout the volume Dr. Holmes's father is called Abdiel instead of Abiel.

Kennedy, William Sloane. Oliver Wendell Holmes, Poet, Littérateur, Scientist. Boston, S. E. Cassino \& Co., 1883.

12mo, pp. 356; portrait.

This volume contains a valuable, although incomplete, bibliography of Dr. Holmes's writings: Appendix II, pp. 334-350.

Morse, John Torrey, Jr. Life and Letters of Oliver Wendell Holmes. Boston and New York, Houghton, Miflin \& Co., 1896. 


\section{[244]}

2 vols., crown 8 vo, pp. viii, 356 , and vi, 335 ; portraits, facsimiles, and cuts. Many letters are included in these volumes; also a number of bits of verse not previously printed; see, in addition to those reprinted in the present compilation, pp. 66, 249, 297, and 353 of vol. i.

SмIтH, J. E. A.

The Poet among the Hills. Oliver Wendell Holmes in Berkshire. His Berkshire Poems; some of them now first published, with Historic and Descriptive Incidents concerning the Poems, the Poet, and his Literary Neighbors. His Poetic, Personal and Ancestral Relations to the County. Pittsfield, G. Blatchford, 1895.

12mo, pp. 182; portraits of Holmes and Longfellow, and 5 full-page plates.

This volume contains, inter alia, Dr. Holmes's speech at the "Jubilee Dinner" at Pittsfield, August 23, 1844 (pp. 65-66); his poem on the same occasion (pp. 67-68); his poem, "The Vision" (pp. 104-105); his speech at the Pittsfield Young Ladies' Institute graduating exercises, in 1849 (pp. 110-111); his poem on the same occasion, "A Vision of Life" (pp. 111113); his "Report of the Committee on the Plowing-Match" at the Cattle-show of the Berkshire Agricultural Society, in 1849 , closing with the poem, "The Plowman," written for that occasion (pp. 129-133); the Dedicatory Poem of Pittsfield Cemetery, September 9, 1850 (pp. 140-144); his poem, "The New Eden," read at the anniversary dinner of the Berkshire Horticultural Society, September 13, 1854 (pp. 146-150); his poem, "Camilla," pp. 153-154; other poems, without titles (pp. 155-157); and letters (pp. 47, 90-93, 94). Of the poems mentioned, "A Vision of Life," "Camilla," and those without titles seem never to have been published in any collection of Dr. Holmes's poems. They are reprinted in the first part of this bibliography, under their respective titles; see supra, pp. 14, 19, 25, 87. "The Vision," said by the author to have been written and used as an epilogue to a lecture on Wordsworth in his Lowell Institute Course on the English Poets of the Nineteenth Century, was first printed in the Knickerbocker Gallery, 1855, pp. 23-26, under the title, "A Vision of the Housatonic;" in Songs in Many Keys, 1862, it appears under the title it has since retained, "After a Lecture on Wordsworth." 


\section{[245 ]}

Vossion, Louis. Un Poète Americain. Oliver Wendell Holmes. Paris, E. Dentu. [1896.]

Pamphlet, 8vo, pp. 26. Signed L. V., and dated at the end, "Philadelphie, 15 Août, 1895."

Such bibliographies of Holmes as have hitherto been published are hardly of a nature to call for listing in a separate category. In addition to those which are noted in the preceding biographies, the following may be mentioned.

Arnold, William Harris. First Editions of Bryant, Emerson, Hawthorne, Holmes, Longfellow, Lowell, Thoreau, Whittier. Collected by William Harris Arnold, 1901.

Boston Medical and Surgical Journal, Oct. 11, 1894, vol. 131, pp. 379-380.

Bibliography of Dr. Holmes's Writings on Medical and Scientific Subjects.

Foley, Patrick Kevin. American Authors, 1795-1895. A Bibliography of First and Notable Editions, Chronologically Arranged, with Notes, 1897, pp. 129-142.

Livingston, Luther S. The First Books of Some American Authors. II, Longfellow, Lowell, Holmes, Bryant.

Bookman, Oct., 1898, vol. 8. Holmes on pp. 141-142.

Page, Cuntis Hidden. The Chief American Poets. Boston, 1905.

Bibliographical matter on p. 645.

Stone, Herbert Stuart. First Editions of American Authors, 1893.

Holmes on pp. 100-105. 


\section{[ 246]}

II

SIGNED ESSAYS, REVIEWS, ETC.

Addison, Daniel Dulany. The Clergy in American Life and Letters (London), 1900.

See Index to the book.

Allen, Alexander V. G. Life and Letters of Phillips Brooks, 1900, vol. ii, p. 686.

F. M. B. With the Autocrat.

Lippincott's Magazine, Jan., 1875, vol. 55, pp. 107-110.

Barker, Dr. Fordyce, A Toast from, to Drs. Holmes and Bigelow.

Boston Medical and Surgical Journal, Jan. 11, 1883, vol. 108, pp. 45-46.

Barrows, Isabel C. Dr. Holmes and the Robin.

Outlook, Oct. 27, 1894, vol. 50, pp. 663-664.

Christian Register, Nov. 8, 1894, vol. 73, pp. 736-737.

Bates, Katharine Lee. American Literature, 1898, pp. 154-159, 227-232.

Beers, Henry A. Initial Studies in American Letters, 1895, pp. 136-143.

Bellows, Albert J., M. D. Currents and Counter-Currents in Medical Science, reviewed in an Address delivered before the Boston Academy of Homœopathic Medicine.

Pamphlet, 8vo, pp. 27. Boston, 1860.

Bidwelt, W. H. Oliver Wendell Holmes.

Eclectic Magazine, May, 1873, vol. 80, p. 632.

Bolton, Sarah K. Oliver Wendell Holmes.

Famous American Authors, 1887, pp. 133-155.

Bowen, Francis. Urania, a Rhymed Lesson [Review].

North American Review, Jan., 1847, vol. 64, pp. 208-216. 


\section{[247 ]}

Boyd, A. K. H. Oliver Wendell Holmes [Review of Morse's Life and Letters].

Longman's Magazine, Aug., 1896, vol. 28, pp. 344-356.

Brunnemann, Dr. K. Geschichte der Nordamerikanischen Literatur [pamphlet], 1868, pp. 115-116.

Burton, Richard. Literary Leaders of America, 1903, pp. 204-220.

P. A. C. How to Study the Chambered Nautilus [A School of Literature].

Poet-Lore, Nov., 1894, vol. 6, pp. 570-576.

Chadwick, John White. Oliver Wendell Holmes.

Forum, Nov., 1894, vol. 18, pp. 279-287.

-. Morse's Holmes.

Nation, June 11, 1896, vol. 62, pp. 456-458.

Chamberlain, Daniel H. John Lothrop Motley [Review of Motley's Correspondence and of Holmes's Memoir of Motley].

New Englander and Yale Review, Oct., 1890, vol. 247, pp. 297-330.

Cheever, David W. Oliver Wendell Holmes, the Anatomist.

Harvard Graduates' Magazine, Dec., 1894, vol. 3, pp. 154159.

Childs, George W. Recollections, 1890, pp. 26-27.

Clarke, H. V.

Munsey's Magazine, vol. 7, p. 400.

Closson, W. B. Homes and Haunts of the Poets. Holmes. Original Etchings. Boston, L. Prang \& Co. (c. 1886.)

Oblong 12mo.

Portrait.

Autograph.

Holmes House (Cambridge).

Study (Boston). 


\section{$[248$ ]}

View from Study Window.

Humility Flat, which is below Pride's Crossing (Beverly Farms).

Collins, Churton. The Poetry and Poets of America.

Cone, Helen Gray.

Critic, Oct. 13, 1894, vol. 25, pp. 243-244.

Cook, Keningale. American Novelists, Iv. Oliver Wendell Holmes.

Belgravia, April, 1873, vol. 20, pp. 222-232.

Cooke, George Wrulis. Dr. Holmes at Fourscore.

New England Magazine, Oct., 1889, n. s. vol. 1, pp. 115123.

Crandall, Charles H. Biographical Sketch.

Representative Sonnets by American Poets, 1890, pp. 332333.

Cullingworth, C. J. Oliver Wendell Holmes and the Contagiousness of Puerperal Fever. An address delivered at Marlborough, Wiltshire, to the Trowbridge division of the Bath and Bristol branch of the British Medical Association, Oct. 28, 1905.

8vo, London, 1906.

Curtis, George Wrlltam. Oliver Wendell Holmes.

Harper's Monthly, July, 1891, vol. 83, pp. 277-285.

Literary and Social Essays, 1895, pp. 205-235.

Delillf, Edward. Oliver Wendell Holmes.

Fortnightly Review, Aug., 1886, vol. 46, pp. 235-243.

Deshler, Charles D. Afternoons with the Poets, 1879, pp. 308-309; including the poem "Joseph Warren."

Doenn, Dr. Rudolf. Aus dem Amerikanischen Dichterwald. Literar-historische Skizzen.

8vo, Leipzig, Otto Wigand, 1881.

Dr. Holmes is discussed on pp. 130-132. On the title-page is this quotation in English:-

"The realm of Song and Beauty

Is the only home of Truth.

"Charles G. Leland." 


\section{[249 ]}

Dwight, Thomas. Reminiscences of Dr. Holmes as Professor of Anatomy.

Scribner's Magazine, Jan., 1895, vol. 17, pp. 121-128.

Fields, AnNiE. Oliver Wendell Holmes.

Warner's Library of the World's.Best Literature, vol. xiii, pp. 7457-7462.

- Oliver Wendell Holmes. Personal Recollections and Unpublished Letters.

Century Magazine, Feb., 1895, n. s. vol. 27, pp. 505-516.

Authors and Friends, 1896, pp. 107-155.

Findlay, Willitam, M. D. Dr. Oliver Wendell Holmes.

Robert Burns and the Medical Profession (London), 1898 pp. 107-110; with extracts from the Burns Centennial poem.

Fisher, Mary. Oliver Wendell Holmes (1809-1894).

General Survey of American Literature, 1899, pp. 260-275.

Foster, Margaret.

Hand-Book of American Literature (London), 1854, pp 82-84.

H. L. G. Oliver Wendell Holmes.

Dublin University Magazine, Sept., 1874, vol. 84, pp. 376-382

Gannett, W. G. Outlines for a Study of Oliver Wendell Holmes.

Outline Studies in Holmes, Bryant, Whittier, 1887, pp. 3-8 (Unity Club Leaflets).

Studies in Longfellow, Whittier, Holmes, and Lowell, 1898, pp. 63-74 (Riverside Literature Series, no. 12).

Gilder, Jeannette L. A Book and its Story. The Genial "Autocrat" [Review of Morse's Life and Letters].

Critic, May 9, 1896, vol. 28, pp. 325-327.

Gilman, Arthur. Oliver Wendell Holmes.

Harvard Register, April, 1881, vol. 3, pp. 185-188.

Gosse, Edmund. An English View of the "Autocrat."

Critic, Dec. 1, 1894, vol. 25, pp. 382-383 (from the St. James Gazette). 


\section{[250.]}

Green, R. F. Oliver Wendell Holmes: his writings and philosophy.

Proceedings Lit. and Phil. Soc., Liverpool, 1880-81, vol. 35, pp. 215-247.

Griswold, Hattie Tyng. Oliver Wendell Holmes.

Home-Life of Great Authors, 1888, pp. 251-261.

Griswold, Rufus Wilmot.

The Prose Writers of America, second edition, 1870, supplement, pp. 620-622.

Hale, Edward Everetr. An Afternoon with Dr. Holmes.

McClure's Magazine, May, 1893, vol. 1, pp. 99.

Human Documents, 1895.

- Oliver Wendell Holmes (including letters from friends of Dr. H.).

Critic, Oct. 13, 1894, vol. 25, pp. 242-246.

—. Impressions of Dr. Holmes.

Outlook, Oct. 20, 1894, vol. 50, pp. 622-623.

—. Oliver Wendell Holmes.

Review of Reviews, Nov., 1894, vol. 10, pp. 495-501.

- Personal Recollections of Oliver Wendell Holmes.

Arena, Dec., 1895, vol. 15, pp. 21-28.

Hale, ENoch. Boylston Prize Dissertations for the years 1836 and 1837 [Review].

North American Review, July, 1838, vol. 47, pp. 161-177.

Hapgood, Norman. Oliver Wendell Holmes.

American Prose, edited by George Rice Carpenter, 1898, pp. 303-307.

Hart, Ernest. Notes of a Conversation with Oliver Wendell Holmes, Sept. 13, 1893.

British Medical Journal, Oct. 13, 1894, vol. 2 of that year, pp. 833-834.

Hatfield, Edwin F. Poets of the Church, 1884, pp. 335338.

The "Hymn of Trust" is included. 


\section{[251]}

Higginson, Thomas Wentwónth. Cheerful Yesterdays, 1898; see Index.

—. Contemporaries, 1899; see Index.

—. Old Cambridge, 1900, pp. 73-108.

- Henry Wadsworth Longfellow (American Men of Letters Series), 1902, pp. 194, 287; and see Index.

Higginson, Thomas Wentworth, and Henry Walcott Boynton. A Reader's History of American Literature, 1903, pp. 154-160.

Hodge, Hugh L., M. D. On the Non-Contagious Character of Puerperal Fever: An Introductory Lecture, delivered Monday, Oct. 11, 1852. Philadelphia, C. K.\& P. G. Collins, 1852.

Pamphlet, 8vo, pp. 52.

See Medical Essays, pp. 109-110, and Morse's Life and Letters, vol. i, p. 164. Dr. Holmes is not mentioned by name.

Hodgkins, Louise Manning. A Guide to the Study of Holmes, 1888, pp. 12 (unpaged).

Howe, JUlia Ward. Reminiscences (1819-1899), 1899, pp. 277-280.

Howe, Mark Antony DeWolfe. American Bookmen, xIr. Longfellow and Holmes.

Bookman, May, 1898, vol. 7, pp. 217-228.

American Bookmen, 1898, pp. 265-286.

Howells, William Dean. Mechanism in Thought and Morals [Review].

Atlantic Monthly, May, 1871, vol. 27, pp. 653-654.

- The Poet at the Breakfast-Table [Review].

Atlantic Monthly, Dec., 1872, vol. 30, pp. 745-746.

-. Songs of Many Seasons [Review].

Atlantic Monthly, Jan., 1875, vol. 35, pp. 105-106.

- The School-Boy [Review].

Atlantic Monthly, Jan., 1879, vol. 43, pp. 120-121. 


\section{[252]}

Howells, William Dean. Oliver Wendell Holmes.

Harper's Monthly, Dec., 1896, vol. 94, pp. 120-134.

—. Oliver Wendell Holmes. Literary Friends and Acquaintance, 1900, pp. 146-177.

Hughes, James L. An Hour with Oliver Wendell Holmes.

Canadian Magazine of Politics, Science, Art, and Literature, Dec., 1893, vol. 2, pp. 134-141; with portrait and facsimiles.

Hughes, Sarah Forbes. Letters and Recollections of John Murray Forbes, 1899, vol. i, pp. 34-35; vol. ii, pp. 159-160.

On p. 35 of vol. i, is a poem - " "To J. M. F. on his Eightieth Birthday, February 23, 1813-February 23, 1893" - apparently not before published. See p. 80, supra.

Ingham, John H. The Poetical Works of Oliver Wendell Holmes.

Academy, Jan. 7, 1882, vol. 21, pp. 4-5.

"Jehu Junior." Men of the Day. No. ccclxit. Dr. Oliver Wendell Holmes. With burlesque portrait.

Vanity Fair (London), June 19, 1886.

"Born seven and seventy years ago at Cambridge, Massachusetts, he took his degree at the age of twenty from Harvard University, and deroted himself to the study of the Law. But after a few months he found that the Law bored him, and he determined to follow Medicine. He accordingly came to Europe, walked the Paris Hospitals, took various medical degrees, and on his return to his native land, married, became the fashionable Boston doctor, and took to Literature; and, although he has filled for five and thirty years, to the great delight of the students and the amazement of his brother Professors, the Chair of Anatomy at Harvard, it is to Literature that he belongs.

"He has written a great many books. His poems are quite harmless and full of common sense and flippancy. They range from Commemoration Odes to Valentines, and are excellent examples of what poetry ought not to be. His novels are an artistic combination of romance and physiology. They are very fantastic, very imaginative, and read like the conversation of a medical student in love. His essays are a sort of Montaigne 


\section{[253 ]}

for families, and can be highly recommended. He is the last of the laughing philosophers, and the author of the wise maxim, ' Give me the luxuries of life, and I will do without its necessaries.' His style scintillates with wit, and, when it is at its best, has all the charm of an exploding cracker. His chief quality is his wonderful versatility. When he writes poetry, he is a professor. When he lectures on anatomy, he is a poet. His novels are the notebooks of a physician; and his philosophy is the kindly observation of a man of the world, the wisdom of one who has dined well.

"Personally, he is a brisk, dapper little man, very brilliant and very bright-eyed; a Puck without malice, an Ariel with a sense of humour. He is very much loved by all who know him, for he has a wholesome dread of people who impart useful information, and thinks that serious conversation is a form of solemn trifling. Attic wit, Yankee humour, a very large supply of human nature, and an absence of any ambition to be president, have made hin the most popular man in America. He has been made much of recently in Iondon Society, and has delighted the Duchesses, for, unlike many Society lions, he has the most genial manners and no mane. On the whole, he is a great success. Though a Bostonian, he is not a prig; though a brilliant conversationalist, he can listen; and though seventyseven years of age, he is still a very young man."

According to Mr. Morse nobody appreciated the very clever caricature, which this text accompanied, more thoroughly than Dr. Holmes himself.

Johnson, Edward Gilpin. The Prose Writings of Oliver Wendell Holmes [Review of vols. i-vi of Riverside Edition].

Dial, Nov., 1891, vol. 12, pp. 209-211.

-. [Review of Morse's Life and Letters.]

Dial, May 16, 1896, vol. 20, pp. 299-302.

Kneeland, Sam'r, JR., M. D. On the Contagiousness of Puerperal Fever, and its Connection with Epidemic Erysipelas. Boston, 1856.

Pamphlet, 8vo, pp. 19.

Dr. Holmes's essay is frequently cited with approval, especially on pp. 7-10. 


\section{[254]}

Lamont, A. Oliver Wendell Holmes. His Touch with Nature and Humanity.

Sunday Magazine, Sept., 1889, vol. 18, pp. 588-595.

LANG, ANDrew. Adventures among Books, 1905, pp. 7996.

Lathrop, George Parsons. The Iron Gate, and Other Poems.

Atlantic Monthly, Nov., 1880, vol. 46, p. 705.

Lawrence, Eugene. A Primer of American Literature, 1880, pp. 104-105, 109.

Lawton, William Cranston. Introduction to the Study of American Literature, 1902, pp. 215-224.

- Holmes's The Last Leaf.

The New England Poets, 1898, pp. 232-254.

Le Baron, Grace. In the Autocrat's Library.

National Magazine, Dec., 1896, vol. 5, pp. 231-236. With portrait and photograph of library.

Lewin, Walter. A Mortal Antipathy, etc. [Review].

Academy, Jan. 16, 1886, vol. 29, p. 37.

—. Oliver Wendell Holmes.

Academy, Oct. 13, 1894, vol. 46, p. 279.

Lodge, Henry Cabot. Dr. Holmes.

North American Review, Dec., 1894, vol. 159, pp. 669-677. 154.

Certain Accepted Heroes and Other Essays, 1897, pp. 135-

Longfellow, Samuel. Life of Henry Wadsworth Longfellow, with Extracts from his Journal and Correspondence, 3 vols., 1886; see Index.

Lovejoy, George Newell. Lunch with Dr. Holmes.

Author, Nov. 15, 1889, vol. 1, pp. 167-169 (from the Chicago Tribune).

Loweld, James Russell. A Fable for Critics.

Poems, Riverside Edition, vol. iii, pp. 84-85.

—. Elsie Venner [Review].

Atlantic Monthly, April, 1861, vol. 7, pp. 509-511. 


\section{[255 ]}

Lowell, James Russell. Letters, 2 vols., New York, 1894; the same, 3 vols., Boston, 1904. Edited by Charles Eliot Norton.

These volumes contain many letters to Dr. Holmes.

Lowell, Percival. Oliver Wendell Holmes.

Proceedings of the American Academy of Arts and Sciences, May 8, 1895, vol. 30, pp. 555-562.

Lodlow, J. M. Elsie Venner and Silas Marner: a Few Words on Two Noteworthy Novels.

Macmillan's Magazine, Aug., 1861, vol. 4, pp. 305-309.

Macrae, David. Oliver Wendell Holmes in 1864.

Pen Pictures of Modern Authors (The Literary Life, II), William Shepard, editor, pp. 144-149.

Matthews, Brander. An Introduction to the Study of American Literature, 1896 (illustrated), pp. 170-183.

Matrhews, Connelius [?]. Review of "Astræa."

Literary World, Oct. 26, 1850.

See “New York 'Pseudo-Critics' in 1850," supra, p. 234.

May, Samuel. Dr. Holmes with his Classmates.

Harvard Graduates' Magazine, Dec., 1894, vol. 3, pp. 159162.

Meigs, Charles D., M. D. On the Nature, Signs, and Treatment of Childbed Fevers, in a Series of Letters addressed to the Students of his Class. Philadelphia, Blanchard \& Lea, 1854.

See Medical Essays, pp. $110 \mathrm{ff}$., and Morse's Life and Letters, vol. i, p. 164. The contagiousness of puerperal fever is discussed in the Sixth Letter, and Dr. Holmes's name is mentioned rather slightingly on p. 93. See also pp. 99-100. The "unpalatable expression" referred to by Dr. Holmes in the introduction to the reprint of his essay on that subject (Medical Essays, p. 110) occurs on p. 113. See Appendix, p. 313, infra.

Merrill, George B. Oliver Wendell Holmes. A paper read at the Twenty-First Annual Dinner of the Harvard Club of San Francisco, Oct. 18, 1894.

Pamphlet, 8vo, pp. 27. 


\section{[256]}

Mitchell, Donald Grant (Ik Marvel). Poet and Professor; as autocrat.

American Lands and Letters, 1899, vol. ii, pp. 331-364.

Mitford, Mary Russell. American Poets. Oliver Wendell Holmes.

Recollections of a Literary Life, 1858, pp. 399-410.

Morse, James Herbert. Oliver Wendell Holmes.

Critic, April 28, 1883, vol. 3, pp. 191-192.

Morse, John Torrey, Jr. Memoir of Oliver Wendell Holmes, D. C. L.

Proceedings of the Massachusetts Historical Society, 1897, 2d series, vol. 11, pp. 47-66.

Morse, Mary Blake. Letters of Dr. Holmes to a Classmate.

Century Magazine, Oct., 1897; n. s. vol. 32, pp. 946-949.

Moulton, Louise Chandler [Review of Morse's Life and Letters].

Bookman, July, 1896, vol. 3, pp. 417-420.

Neidhard, Charles, M. D. An Answer to the Homœopathic Delusions of Dr. Oliver Wendell Holmes. Kámvov

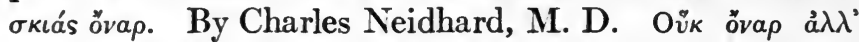
ĩrap. Philadelphia, 1842.

Pamphlet, 8vo, pp. 36.

"When I published my lectures on Homœopathy and its Kindred Delusions, I had three formal pamphlets, besides miscellaneous newspaper squibs, launched at my head - from Boston, Providence, and Philadelphia." - O. W. H. to Dr. J. C. Warren, April 14, 1873, quoted in Morse's Life and Letters, vol. i, p. 350.

The three pamphlets were Dr. Neidhard's, Dr. Okie's, and Dr. Wesselhoeft's.

Newcomer, A. G. American Literature, 1901, pp. 230-241.

Nichol, John. American Literature; an Historical Sketch [Edinburgh], 1882, pp. 249-250, 357-361, 407-411. 


\section{[257 ]}

Noble, James Ashcroft. Oliver Wendell Holmes.

Leisure Hour, Dec., 1894, vol. 44, pp. 82-88.

Impressions and Memories, 1895, pp. 19-35.

Окіе, А. H., M. D. Hотœораthy: with particular reference to a Lecture by O. W. Holmes, M. D. Providence, 1842.

Onderdonk, James L. History of American Verse (16101897), 1901, pp. 268-279; and see Index.

Osler, Wiluiam. Oliver Wendell Holmes.

Johns Hopkins Hospital Bulletin, Oct., 1894.

Reprinted in pamphlet form, 8vo, pp. 10.

Oswald, Felix L. Dr. Oliver Wendell Holmes's Health Code.

Chautauquan, Dec., 1894, vol. 20, pp. 321-325.

Page, Curtis Hidden. Biographical Sketch.

The Chief American Poets, 1905, pp. 677-679.

Palfrey, John G. Poems by Oliver Wendell Holmes [Review of 1st edition].

North American Review, Jan., 1837, vol. 44, pp. 275-277.

- Urania [Review].

North American Review, Jan., 1847, vol. 64, pp. 208-216.

Palmer, Ray. Oliver Wendell Holmes.

International Review, May, 1880, vol. 8, pp. 501-514.

Panconst, Henry S.

An Introduction to American Literature, 1900, pp. 211-218.

Payne, W. M. Little Leaders, 1895.

Pennell, Eumzabeth Robins.

Atlantic Monthly, March, 1905, vol. 95, pp. 312-313 ("A Bundle of Old Letters").

Charles Godfrey Leland, 1906; see Index.

Phelps, Elizabeth Stuart.

McClure’s Magazine, vol. 7, p. 114. 


\section{[258]}

Porter, Maria S. Oliver Wendell Holmes.

Bostonian, June, 1895, vol. 2, pp. 243-253; with portrait and facsimiles.

Prothero, R. E. Oliver Wendell Holmes.

Longman's Magazine, July, 1886, vol. 8, pp. 300-306.

Putnam, Alfred Porter, editor. Oliver Wendell Holmes.

Singers and Songs of the Liberal Faith, 1875, pp. 252-261. (Biog. sketch, pp. 252-253; poems, 254-261.)

Putnam, James Jackson. A Memoir of Dr. James Jackson, with Sketches of his Father, etc. Boston and New York, Houghton, Miffin \& Co., 1905.

See Index for references to Dr. Holmes, letters, etc.

Richardson, Charles F.

A Primer of American Literature, 1878, pp. 58-60.

American Literature, 1607-1885 (1889), vol. ii, pp. 204-218.

Rideing, William H. Holmes in Cambridge and Boston.

Chautauquan, Oct., 1887, vol. 8, pp. 15-16.

Boyhood of Living Authors, 1887, pp. 1-15.

Roe, Alfred S. American Authors and their Birthdays;

Programmes and Suggestions for the Celebration of the Birthdays of Authors, 1887, pp. 22-28.

Riverside Literature Series, $A$.

Rollins, Alice Wellington. Authors at Home, iv. Dr. Oliver Wendell Holmes in Beacon St.

Critic, Jan. 3, 10, 1885, vol. 6, pp. 1-2, 13-14.

Authors at Home (Jeannette L. and Joseph B. Gilder), 1888, pp. 163-179.

Sanborn, Frankuin B. Oliver Wendell Holmes.

Homes and Haunts of Our Elder Poets, R. H. Stoddard, editor, 1881, pp. 137-162; with portrait and facsimiles.

Saunders, Frederic. Famous Books, 1887, pp. 196-197.

Savage, Minot Judson. The Religion of Holmes's Poems. 


\section{[259 ]}

Unity Pulpit, Oct. 19, 1894, vol. 16, no. 3. ${ }^{1}$

Arena, Dec., 1894, vol. 11, pp. 41-54.

Schurz, Carl. Reminiscences of a Long Life.

McClure's Magazine, Jan., 1907, vol. 28, p. 259.

Scudder, Horace E. Ralph Waldo Emerson [Review].

Atlantic Monthly, March, 1885, vol. 55, pp. 416-417.

- Our Hundred Days in Europe [Review].

Atlantic Monthly, Dec., 1887, vol. 60, pp. 851-852.

—. Biographical Sketch.

Masterpieces of American Literature, 1891, pp. 65-67.

- Dorothy $\mathbf{Q}$ [Review].

Atlantic Monthly, Jan., 1893, vol. 71, p. 124.

—. Dr. Holmes.

Atlantic Monthly, Dec., 1894, vol. 74, pp. 831-834.

—. Biographical Sketch.

Poems, Cambridge Edition, 1895, pp. xi-xxi.

- James Russell Lowell. A Biography, 1899, vol. i,

pp. 248-249, 251-252, 413, 426, 448; vol. ii, pp. 83, 365; and see Index.

Simonds, Arthur B. Introduction.

American Song, 1894, pp. 91-94.

Smalley, George W. Oliver Wendell Holmes.

Studies of Men, 1895, pp. 314-333.

Smith, Samuel F. Oliver Wendell Holmes.

Harvard Graduates' Magazine, Dec., 1894, vol. 3, p. 153.

Stearns, Frank Preston. Dr. Holmes.

Cambridge Sketches, 1905, pp. 142-161.

Stedman, Arthur. Biographical Sketch.

Library of American Literature, E. C. Stedman and Ellen M. Hutchinson, editors, 1890, vol. xi, p. 529 .

Stedman, Edmund Clarence. Poets of America, 1885, pp. 273-303.

${ }^{1}$ On pp. 19-20 is the letter sent by Dr. Holmes to be read at the Whittier Commemoration at the B. Y. M. C. U., May 28, 1894. See p. 198, supra. Mr. Savage quotes a number of the poems. 


\section{[260:]}

Stephen, Lesuie. Oliver Wendell Holmes [Review of Morse's Life and Letters of Dr. Holmes].

National Review, July, 1896, vol. 27, pp. 626-641.

Littell's Living Age, Aug. 1, 1896, vol. 210, pp. 259-269.

Eclectic Magazine, Sept., 1896, vol. 127, pp. 359-369.

Studies of a Biographer, 1898, vol. ii, pp. 160-195.

Stewart, George, Jr. Oliver Wendell Holmes.

Belford's Monthly Magazine, Feb., 1877, vol. 1, pp. 371-390.

Evenings in the Library (Toronto), 1878, pp. 52-73.

- Oliver Wendell Holmes.

Arena, July, 1891, vol. 4, pp. 129-141.

Essays from Reviews (Quebec), 1892, pp. 109-138.

Mr. Stewart was a frequent correspondent of Dr. Holmes. Mr. S. H. Wakeman has in his collection an interesting autograph letter to Mr. S., concerning the two sonnets written for the meeting of the Harvard Club of New York in February, 1878. See p. 32, supra.

Sweener, Helen M. Tennyson and Holmes; a parallel.

Catholic World, Jan., 1895, vol. 60, pp. 521-534.

TaYlor, Bayard. Oliver Wendell Holmes [Review of Poems, Household Edition, 1877].

Critical Essays and Literary Notes, 1897, pp. 301-302.

Thompson, Alice Meynell. Dr. Oliver Wendell Holmes.

The Rhythm of Life and Other Essays, 1897 (6th edition), pp. 60-67.

Trent, William P. A History of American Literature, 1903, pp. 419-428; and see Index.

This book is published in the series Short Histories of the Literatures of the World, edited by Edmund Gosse.

Trowbridge, John Townsend. My Own Story: with Recollections of Noted Persons, 1903; see Index.

Underwood, Francis H. Oliver Wendell Holmes.

Scribner's Monthly, May, 1879, vol. 18, pp. 117-127.

Good Words, 1887, vol. 28, pp. 298-304. 


\section{[ 261 ]}

Vaille, Frederick Ozin, and Clark, Henry Allen. Oliver Wendell Holmes.

Harvard Book, 1875, vol. i, pp. 253-254.

Vedder, Henry C. American Writers of To-Day, 1895; see Index.

Vincent, Leon H. Oliver Wendell Holmes.

American Literary Masters, 1906, pp. 335-355.

Walsh, William Shepard. Lowell and Holmes.

Pen Pictures of Modern Authors, 1882, pp. 135-149.

Wendell, Barrett. A Literary History of America, 1900, pp. 407-424.

Wesselhoeft, Robert. Some Remarks on Dr. O. W. Holmes's Lectures on Homœopathy and its Kindred Delusions, communicated to a friend: "Many are called, but few are chosen." Boston, 1842.

Pamphlet, 8vo, pp. 59.

Contains 17 letters and an appendix.

Whipple, Edwin P. [Review of Griswold's Poets and Poetry of America].

North American Review, Jan., 1844.

Essays and Reviews, 1848.

- Currents and Counter-Currents in Medical Science [Review].

Atlantic Monthly, Aug., 1861, vol. 8, pp. 253-254. 76-78.

Whittier, John Greenleaf. Mirth and Medicine [Review of Poems, 1849].

Littell's Living Age, March 17, 1849, vol. 20, pp. 516-518 (from the National Era).

Literary Recreations, 1854, pp. 143-153.

Prose Works (Riverside Edition), vol. iii, pp. 374-382. 


\section{[262]}

Whittier, John Greenleaf. Oliver Wendell Holmes.

Critic, Aug. 30, 1884.

Prose Works (Riverside Edition), vol. ii, pp. 309-311.

Wilson, James Grant. Dr. Holmes and Old Ironsides.

Bookman, May, 1904, vol. 19, pp. 315-317.

Woodberry, George Edward. Before the Curfew, and Other Poems [Review].

Atlantic Monthly, July, 1888, vol. 62, pp. 123-125.

- Oliver Wendell Holmes.

Nation, Oct. 11, 1894, vol. 59, pp. 264-265.

—. America in Literature, 1903, pp. 108-109.

Wright, Henrietta Christian. Children's Stories in American Literature (1660-1860), 1895, Series II, pp. 234-249. 


\section{[263]}

\section{III}

\section{ESSAYS, REVIEWS, AND OTHER ANONYMOUS}

ARTICLES, ARRANGED IN CHRONOLOGICAL ORDER

Review of the Laurel; a Gift for All Seasons, 1836.

Knickerbocker, or New York Monthly Magazine, Feb., 1836, vol. 7, p. 219.

"The Last Leaf" was printed in the Laurel, and a few lines of the review are devoted to that poem.

American Monthly Magazine, March, 1836, n. s. vol. 1, pp. 305-309.

"The Last Leaf" and "Old Ironsides" are reviewed on pp. 306-307.

Review of Poems, 1836.

American Monthly Magazine, Jan., 1837, n. s. vol. 3, pp. 7378.

Nearly the whole review is devoted to "Poetry: a Metrical Essay."

The Token and Atlantic Souvenir, 1838 [Review].

American Monthly Magazine, Nov., 1837, n. s. vol. 4, pp. 486488.

"The Only Daughter," which was first printed in this issue of the Token, is criticised rather severely.

Position and Prospects of the Medical Student [Review].

Graham's Magazine, May, 1844, vol. 24, p. 240.

Holmes in England: a London Edition of his Poems.

Knickerbocker Magazine; Dec., 1845, vol. 26, pp. 570-573.

Review of Poems (London), 1846.

Graham's Magazine, Jan., 1846, vol. 28, p. 48. 


\section{[264]}

Dr. Holmes's Introductory Lecture as Parkman Professor, Nov. 3, 1847.

Boston Medical and Surgical Journal, Dec. 8 and 15, 1847, vol. 37, pp. 384, 408.

Review of Poems, 1849.

North American Review, Jan., 1849, vol. 68, pp. 201-203.

"On Lending a Punch-Bowl" is given in full.

Graham's Magazine, Jan., 1849, vol. 34, pp. 82-83.

Littell's Living Age, Jan. 6, 1849, vol. 20, p. 47.

Astrea [Review].

Graham's Magazine, Dec., 1850, vol. 37, pp. 385-386.

The poem is called "Astræa: the Balance of Delusions."

Astrea: Oliver Wendell Holmes. By a New Contributor.

Knickerbocker Magazine, Feb., 1851, vol. 37, pp. 142-151.

American Authorship, vi. By Sir Nathaniel. Oliver Wendell Holmes.

Colburn's New Monthly Magazine, Sept., 1853, vol. 99, pp. 77-84.

Littell's Living Age, Oct. 8, 1853, vol. 39, pp. 100-104.

The article concludes thus: "On the whole, here we have, in the words of a French critic, 'un poëte d'élite, et qui conte: c'est une nature individuelle très-fine et très-marquée' - one to whom we owe 'des vers gracieux et aimables, vifs et légers, d'une gaieté nuancée de sentiment.' And one that we hope to meet again and again."

Oliver Wendell Holmes.

Eclectic Magazine, Dec., 1853, vol. 30, pp. 532-536.

Oliver Wendell Holmes.

National Magazine (New York), Dec., 1853, vol. 3, pp. 502507.

The Poets of America. 4. The Poetical Works of Oliver Wendell Holmes, London, 1852.

Irish Quarterly Review, June, 1855, vol. 5, pp. 215-220.

Gives an extract from "Poetry;" also "The Star and the Water-Lily," "The Last Leaf," "My Aunt," "Evening," and "The Stethoscope Song." 


\section{[265]}

Conversation Holmes [Review of the Autocrat of the Breakfast-Table].

Chambers's Journal, Jan. 22, 1859, vol. 11, pp. 59-61.

Review of the Autocrat of the Breakfast-Table.

Littell's Living Age, March 5, 1859, vol. 60, pp. 630-632 (from the Economist).

American Humour ["Autocrat" and "Professor"].

North British Review, Nov., 1860, vol. 33, pp. 476-479.

The Professor's Story [Review].

Boston Review, July, 1861, vol. 1, pp. 384-398.

Dr. Oliver Wendell Holmes and Elsie Venner.

National Review, July, 1861, vol. 13, pp. 359-372.

Littell's Living Age, Dec. 7, 1861, vol. 71, pp. 435-442.

Dr. Holmes's Introductory LeCtURe.

Boston Medical and Surgical Journal, Nov. 14, 1861, vol. 65, pp. 318-319.

Songs in MaNY Keys.

Harvard Magazine, Dec., 1861, vol. 8, pp. 151-160.

The writer of this article, presumably an undergraduate, deals very severely with Dr. Holmes's poetical talent. He says, among other things, "The present volume is significantly entitled 'Songs in Many Keys,' - indeed in almost every key but the right one, which it would be hard to find anywhere in the book. ...

"If a young man has a right to speak critically of an older man, we should say that Mr. Holmes writes too much and writes too hastily, and that the greedy lust after the newspaper reputation of to-day is but too dearly gratified in the utter wreck of all literary hopes for the future."

A Batch of Last Year's Novels [Review of Elsie Venner].

Dublin University Magazine, April, 1862, vol. 59, pp. 401404.

Review of Blue and Gold Edition of Poems, 1862.

Harvard Magazine, Oct., 1862, vol. 9, p. 71.

Review of Holmes's Currents and Counter-Currents in Medical Science.

Boston Review, Nov., 1862, vol. 2, pp. 583-589. 


\section{$[266$ ]}

[Dr. Holmes's Introductory Lecture.]

Boston Medical and Surgical Journal, Nov. 13, 1862, vol. 67, p. 307.

\section{Verse, Poetry and O. W. Holmes.}

Knickerbocker, March, 1863, vol. 61, pp. 189-193.

This is rather a severe review of the Blue and Gold Edition of the poems. The reviewer's text is: "his so-called poems are only verses."

\section{Oliver Wendell Holmes.}

Sketches of Distinguished American Authors represented in Darley's New National Picture, entitled Washington Irving and his Literary Friends at Sunnyside, 1863, p. 50.

Scholastic and Bedside Teaching, commented on.

Boston Medical and Surgical Journal, Nov. 7, 1867, and Jan. 9, 1868, vol. 77, pp. 298, 479-483.

The Guardian Angel [Review].

Nation, Nov. 14, 1867, vol. 5, pp. 390-391.

"Your kind womanly words affect me more gratefully perhaps on account of the stinging phrases which have been made for me by a writer in the Nation, whose aim from the first seems to have been to wound if possible, to injure at any rate. I suppose I know who he is, and only wonder how he came to take me for his souffre-douleur." - O. W. H. to Harriet Beecher Stowe, Nov. 17, 1867, quoted in Morse's Life, vol. ii, p. 223.

The Guardian Angel [Review].

Every Saturday, Dec. 7, 1867, vol. 4, pp. 728-730.

American Humour. [3] The Autocrat of the BreakFAST-TABLE.

British Quarterly Review, Oct., 1870, vol. 52, pp. 324-351.

Oliver Wendell Holmes.

Every Saturday, Dec. 30, 1870, vol. 11, p. 642.

The Poet at the Breakfast-Table [Review].

Spectator, Nov. 23, 1872, vol. 45, pp. 1493-1494.

Oliver Wendell Holmes.

Every Saturday, April 26, 1873, vol. 14, pp. 466-469. 


\section{[ 267 ]}

The Poet at the Breakfast-Table [Review].

Southern Review, July, 1873, vol. 13, pp. 26-36.

Ouiver Wendell Holmes.

Appleton's Journal, Oct. 13, 1874, vol. 12, pp. 545-547.

Oliver Wendell Holmes, Brographical Sketch.

Harvard Book, 1875, vol. i, pp. 252-253; with portrait.

The Holmes Breakfast, Dec. 3, 1879.

Atlantic Monthly, Feb.. 1880, vol. 45, supplement, pp. 1-24.

Contents:-

Mr. H. O. Houghton's remarks 1-3

Dr. Holmes's poem, "The Iron Gate" 4-5

Dr. Holmes's Reminiscence (read by Mr. Houghton) 5

Mr. Whittier's poem, "Our Autocrat" 5-6

Mr. W. D. Howells's response 6-7

Mrs. Julia Ward Howe's remarks and poem 7-8

Mr. C. D. Warner's speech 8-9

Mrs. Helen Hunt Jackson's poem, “To Oliver Wendell Holmes on his Seventieth Birthday" (read by Mr. Warner)

President Eliot's speech 10-11

Mark Twain's explanation 11-12

Mr. J. W. Harper's speech 12-13

Mr. E. C. Stedman's poem 13-14

Mr. Aldrich's speech $\quad 14$

Mr. Winter's poem - "Hearts and Holmes" ["The Chieftain"]

14-15

Mr. Trowbridge's poem 15-16

Mr. Cranch's sonnet 17

Mr. T. W. Higginson's speech 18

Mr. Field's Fairy Tale (not read) 19

In addition, many letters are printed, some of which were read at the Breakfast, and some not.

Poetical Works [Review].

Modern Review, Jan., 1882, vol. 3, pp. 223-224.

Dr. Oliver Wendell Holmes on Medicine.

Medical Times and Gazette [London], Sept. 16, 1882, vol. 2 of that year, pp. 356-357.

Boston Medical and Surgical Journal, Oct. 5, 1882, vol. 107, pp. 331-332. 


\section{[268: $]$}

Dr. Oliver Wendell Holmes's Resignation of the Parkman Professorship of Anatomy in Harvard UNIVERSITY.

Boston Medical and Surgical Journal, Nov. 2, 1882, vol. 107, pp. 426-427.

Oliver Wendell Holmes.

The Sanitarian, 1883, vol. 11, p. 337; with portrait.

A Reception to Drs. Holmes and Bigelow.

Boston Medical and Surgical Journal, Jan. 4, 1883, vol. 108, p. 22.

Appointment of Oliver Wendell Holmes Emeritus Professor of Anatomy in Harvard University.

Boston Medical and Surgical Journal, Jan. 11, 1883, vol. 108, p. 46.

The New York Dinner to Dr. Holmes.

Boston Medical and Surgical Journal, April 19, 1883, vol. 108, pp. 378, 379-380.

Presentation of a Portratt of Professor Holmes to the Harvard Medical School.

Boston Medical and Surgical Journal, Oct. 25, 1883, vol. 109, p. 404 .

New Facts about Dr. Holmes.

Boston Medical and Surgical Journal, April 3, 1884, vol. 110, p. 334.

Quotation from an article on Dr. Holmes, his writings and his philosophy, in the Proceedings of the Literary and Philosophical Society of Liverpool, 1881: "Besides the Professorship at Dartmoor, he founded and carried on a medical school at Fremont and had a large private practice."

E. E. Brown's Life of Holmes [Review].

Saturday Review, May 17, 1884, vol. 57, p. 651.

Oliver Wendell Holmes on his Seventy-Fifth BirthDAY. 1809-1884.

Critic, Aug. 30, 1884, n. s. vol. 2, pp. 97-108.

This was a "Holmes Number," and, in addition to the editorial 


\section{[269]}

article (by Miss Gilder), ${ }^{1}$ contained letters from Matthew Arnold, Louisa M. Alcott, William F. Allen, Charles Barnard, Cyrus A. Bartol, H. H. Boyesen, Noah Brooks, Phillips Brooks, Frances Brown, John Burroughs, James Freeman Clarke, J. Esten Cooke, Rose Terry Cooke, Christopher P. Cranch, George William Curtis, Austin Dobson, Mary Mapes Dodge, R. Ogden Doremus, Samuel Adams Drake, Edward Eggleston, George P. Fisher, John Fiske, O. B. Frothingham, H. H. Furness, W. H. Furness, Sydney Howard Gay, W. A. Hammond, W. T. Harris, J. R. G. Hassard, Julian Hawthorne, John Hay, Paul H. Hayne, Frederic H. Hedge, H. C. Lea, Benson J. Lossing, Donald G. Mitchell, James H. Morse, Simon Newcomb, F. W. Palfrey, Elizabeth Stuart Phelps, Henry C. Potter, H. W. Shaw ("Josh Billings"), E. C. Stedman, Frank R. Stockton, Harriet Beecher Stowe, Maurice Thompson, J. T. Trowbridge, Moses Coit Tyler, Francis A. Walker, George E. Waring, Jr., Charles Dudley Warner, Andrew D. White, J. G. Whittier, Alex Winchell, C. A. Young. Also poems by C. de K., Julia C. R. Dorr, R. W. Gilder, Edmund Grosse, Edward Everett Hale, Bret Harte, Lord Houghton, Frederick Locker, Alice Wellington Rollins, and Edith M. Thomas.

Dr. Holmes's "Last Leaf."

Literary World, Nov. 28, 1885, vol. 16, p. 429.

Dr. Haweis on Dr. Holmes.

Critic, Jan. 23, 1886, vol. 8, pp. 46-47 (from the Pall Mall Gazette).

Dr. Holmes's New Novel [Review of A Mortal Antipathy].

Literary World, Jan. 23, 1886, vol. 17, p. 23.

Dr. Oliver Wendell Holmes.

British Medical Journal, April 10, 1886, vol. 1 of that year, p. 707.

The American Montaigne.

Spectator, May 15, 1886, vol. 59, pp. 650-651.

Oliver Wendell Holmes.

British Medical Journal, June 12 and June 26, 1886, vol. 1 of that year, pp. 1121 and 1223.

1 Including a facsimile of a letter from Dr. Holmes. 


\section{[270:]}

[Dr. Holmes at Oxford.]

Christian Union, June 24, 1886, vol. 33, p. 3.

Dr. Holmes in England.

Literary World, June 26, 1886, vol. 17, p. 216.

Dr. Holmes in England.

Boston Medical and Surgical Journal, June 30, 1886, vol. 114, p. 626.

Dr. Oliver Wendell Holmes (Phœbo ante alios dilectus).

Boston Medical and Surgical Journal, Sept. 2, 1886, vol. 115, p. 217.

Portratts and Biographical Sketches of Twenty American Authors. Boston, 1887.

Riverside Literature Series, B. Holmes, no. 9 (unpaged).

Recreations of the Rabelats Club, 1885-1888. [For private circulation only. 100 copies printed.]

In this third series of the "Recreations," 10 lines from "The Old Player" are printed, followed by a translation into Latin by S[amuel] L[ee]; the Latin version is then put into Greek by A. S., and that into English by A[ndrew] L[ang]. Mr. Lang's English version is then done into French by W[alter] H[erries] P[ollock]; the French version into Italian by S. G. C. M[iddlemere], and that back into English once more by Mr. Pollock.

Mr. Lang's and Mr. Pollock's English versions are given below, together with the original passage.

\section{Dr. Holmes}

Call him not old, whose visionary brain Holds o'er the past its undivided reign.

For him in vain the envious seasons roll

Who bears eternal summer in his soul.

If yet the minstrel's song, the poet's lay, Spring with her birds, or children at their play,

Or maiden's smile, or heavenly dream of art, Stir the few life-drops creeping round his heart, Turn to the record where his years are told, Count his gray hairs, - they cannot make him old. 


\section{[271 ]}

Mr. LANG

Call him not old whose kindly breast

Retains the glow of seasons dead,

Within whose heart is summer blest

Despite the cruel winters fled;

While yet the minstrel brings delight

To such a soul with piercing song,

While laughing girls and all things bright

Of mortal art can please him long -

$\mathrm{Ah}$, though the warm heart-drops be rare,

He yet is young, as he hath been,

Beneath whose crown of silver hair

Life and the love of life are green.

\section{Mr. Pollock}

Say not that he is old. His heart

Is lord of bygone time.

Winter in vain with envious smart

Puts rime against his rhyme.

His soul is summer. While the laugh of birds,

Or happy girls, or children, makes him young,

While he can think such thoughts, can write such words,

Can sing again such songs as he has sung,

"Stone walls do not a prison make, nor iron bars a cage,"

Nor whitening hairs do not reveal his age.

Dr. Holmes in his Library.

Book-Buyer, June, 1888, n. s. vol. 5, pp. 174-175.

Before the Curfew, and Other Poems [Review].

Spectator, June 23, 1888, vol. 61, pp. 855-856.

Before the Curfew, and Other Poems [Review].

Athenæum, June 28, 1888, no. 3165, pp. 787-788.

Dr. Holmes's Eightieth Birthday.

Critic, Sept. 7, 1889, vol. 15, p. 115.

Dr. Holmes's Reijgious Poems.

New England Magazine, Oct., 1889, vol. 1, pp. 124-125.

Dr. Holmes at Beverly Farms.

Critic, Sept. 20, 1890, vol. 17, pp. 147-148 (from the Boston Daily Advertiser). 


\section{[278 ]}

Oliver Wendell Holmes.

Blackwood's Magazine, Aug., 1892, vol. 152, pp. 194-207.

The Writings of Oliver Wendell Holmes [Review of Riverside Edition].

Spectator, Sept. 17, 1892, vol. 69, pp. 387-388.

Massachusetts Historical Society, Proceedings of, on the Death of Oliver Wendell Holmes.

Proceediugs, etc., Oct. 11, 1894, 2 d series, vol. 9, pp. 159-168.

Remarks of George E. Ellis.

Poem of William Everett.

Letter from Hon. E. R. Hoar.

Remarks of Henry Lee.

Remarks of Hon. George F. Hoar.

Remarks of Charles W. Eliot.

Oliver Wendell Holmes.

Boston Medical and Surgical Journal, Oct. 11, 1894, vol. 131, pp. 375-376.

Outver Wendell Holmes.

Outlook, Oct. 13, 1894, vol. 50, pp. 578-579.

Dr. Oliver Wendell Holmes.

Athenæum, Oct. 13, 1894, no. 3494, pp. 492-493.

Oliver Wendell Holmes.

Critic, Oct. 13, 1894, vol. 25, p. 242.

Oliver Wendell Holmes.

Saturday Review, Oct. 13, 1894, vol. 78, pp. 406-407.

Oliver Wendell Holmes.

Spectator, Oct. 13, 1894, vol. 73, pp. 485-487.

Littell's Living Age, Nov. 24, 1894, vol. 203, pp. 503-506.

[Oliver Wendell Holmes.]

Lancet (London), Oct. 13, 1894, vol. 2 of that year, pp. 862863 and 882-883.

The first is an editorial article upon Dr. Holmes, and the second an "obituary."

[Oliver Wendell Holmes.]

British Medical Journal, Oct. 13, 1894, vol. 2 of that year, pp. 839-841. 
Oliver Wendell Holmes.

Dial, Oct. 16, 1894, vol. 17, pp. 215-217.

Oliver Wendell Holmes.

Public Opinion, Oct. 18, 1894, vol. 17, p. 707.

Oliver Wendell Holmes.

Literary World, Oct. 20, 1894, vol. 25, p. 350.

Medical Tributes to Dr. Holmes.

Boston Medical and Surgical Journal, Oct. 25, 1894, vol. 131, pp. 423-425.

\section{Oliver Wendell Holmes.}

Writer, Nov., 1894, vol. 7, pp. 161-167, 183.

Personal tributes to the memory of Dr. Holmes, written at the request of the editor of the Writer, by F. B. Sanborn (poem), Charles Dudley Warner, Edward Eggleston, H. H. Boyesen, C. A. Bartol, George W. Cable, S. F. Smith, Julia C. R. Dorr (sonnet), Donald G. Mitchell, William H. Hayne, Richard Burton, Arlo Bates, J. T. Trowbridge, Thomas Nelson Page, Elizabeth Stuart Phelps Ward, Joaquin Miller, and others. On p. 168 of the same number is an editorial article on Dr. H., and on p. 169 a letter from Rev. Edward E. Hale, inclosing a copy of a letter from Dr. H. to himself, dated Dec. 7, 1869.

\section{[Oliver Wendell Holmes.]}

Book News, Nov., 1894, vol. 13, pp. 70-72; with portrait, quotations from the New York Sun, and from certain articles in the Holmes number of the Critic.

The Last Leaf [Review of Holiday Edition].

Outlook, Dec. 1, 1894, vol. 50, p. 916.

Holmes Memorial Meeting of Boston Medical Library Association, Tuesday, Oct. 30, 1894.

Boston Medical and Surgical Journal, Dec. 13, 1894, vol. 131, pp. 584-590.

[Oliver Wendell Holmes.]

Newsletter, Osterhout Library, Wilkesbarre, Pa., Dec., 1894.

Oliver Wendell Holmes [Review of Riverside Edition of his Works]. 


\section{[274:]}

Quarterly Review, Jan., 1895, vol. 180, pp. 189-206.

Littell's Living Age, March 2, 1895, vol. 204, pp. 537-549.

Eclectic Magazine, April, 1895, vol. 124, pp. 433-444.

Mr. Morse refers more than once to this article as a most judicious and discriminating one.

Oliver Wendell Holmes. 1809-1894.

Bulletin of Providence [R. I.] Public Library, Jan., 1895, vol. 1, pp. 3-4.

Oliver Wendell Holmes on Immortality.

Spectator, May 16, 1896, vol. 76, pp. 699-700.

Dr. Holmes - Sic Sedebat [Review of Morse's Life and Letters of Dr. Holmes].

Atlantic Monthly, June, 1896, vol. 77, pp. 830-837.

[Review of Morse's Life and Letters.]

Book News, June, 1896, vol. 14, pp. 477-478 (from the New York Times).

Life and LetTers of Oliver Wendell Holmes [Review of Morse's Life and Letters, and Jerrold's Oliver Wendell Holmes].

Quarterly Review, Oct., 1896, vol. 87, pp. 77-94. 


\section{[275 ]}

\section{IV}

\section{POEMS}

Aldrich, Thomas Barley. The Sailing of the Autocrat. On Board the S. S. Cephalonia, April 26, 1886.

The Sisters' Tragedy, with Other Poems, 1891.

The last line reads

"His absence will be shadow here."

After the death of Dr. Holmes the following lines were added to the poem, beneath the words "October 7, 1894," and have always since been printed with them:-

" 'His absence will be shadow here'-

A deeper shadow than I meant

Has fallen on the waning year

And with my lightsome verses blent.

Another voyage was to be! -

The ship that bears him now from shore,

To plough an unknown, chartless sea,

Shall bring him back to us no more!"

Anonymous. Sweet Holmes! [Dr. Oliver Wendell Holmes has resigned the Chair of Anatomy at Harvard University.]

Punch, Dec. 9, 1882, vol. 82, p. 274.

Boston Medical and Surgical Journal, Jan. 25, 1883, vol. 108, p. 86.

Your health, dear "Autocrat!" All England owns

Your instrument's the lyre, and not "the Bones."

Yet hear our wishes - trust us they 're not cold ones!

That though you give up bones, you may make old ones.

Anonymous. Lyrics in a Library, II. Oliver Wendell Holmes.

Punch, April 10, 1886, vol. 89, p. 178.

$O$ Thou, whose wisdom and whose wit, Whose fancy and whose fable, 


\section{[276]}

Have won two hemispheres to sit Around thy breakfast table,

Our old-world notions never find A more indulgent critic,

Though your sharp scalpel lurks behind Your verdicts analytic.

In Elia's hand the essay writ

With admirable fancy

A thousand prosy subjects lit

With potent necromancy.

So now across the Western seas, Atlantic billows tost on,

There comes, in precious books like these,

A LamB "designed of Boston."

I never crossed from this old shore

Atlantic ocean ridges,

I never heard the Charles downpour

Through all the Boston bridges;

And yet, I seem to know your home,

The "Hub," the Boston people;

To see the State House with its dome,

Hear chimes from Christchurch steeple.

For I have pondered o'er each page,

Till half by heart I know it,

Of keen "Professor," kind and sage,

Of tender-hearted "Poet;"

Before the "Autocrat" I see

In vain his foemen flounder,

Like Don Diego Perez, he,

A veritable "pounder."

One idyl to my heart of hearts,

Professor, you have granted,

Though scarce susceptible to darts

By Aphrodite planted.

In Dreamland Iris still I woo;

It raises up my dander,

To think she married even you,

A happy Marylander! 


\section{[277 ]}

So trust me, Doctor, writing here, Afar 'mid English daisies,

Howe'er unkempt my rhymes appear,

That honest are my praises.

I cry "Peccavi!" if you care

With my poor verse to quarrel,

Yet $P$ unch may ask you 'll deign to wear

This leaf of English Laurel.

Anonymous. "The Autocrat." Oliver Wendell Holmes.

Born 1809. Died October 7, 1894.

Punch, Oct. 20, 1894, vol. 106, p. 191.

Life and Letters of Oliver Wendell Holmes (Morse), vol. ii, pp. 96-97.

The Last Leaf! Can it be true,

We have turned it, and on you.

Friend of all?

That the years at last have power?

That life's foliage and its flower

Fade and fall?

Was there ever one who took

From its shelf, by chance, a book,

Penned by you,

But was fast your friend for life,

With one refuge from its strife

Safe and true?

Even gentle Elia's self

Might be proud to share that shelf,

Leaf to leaf,

With a soul of kindred sort,

Who could bind strong sense and sport

In one sheaf.

From that Boston breakfast-table,

Wit and wisdom, fun and fable,

Radiated

Through all English-speaking places.

When were Science and the Graces

So well mated? 


\section{[278]}

Of sweet singers the most sane, Of keen wits the most humane,

Wide, yet clear,

Like the blue, above us bent, Giving sense and sentiment

Each its sphere;

With a manly breadth of soul, And a fancy quaint and droll,

Ripe and mellow;

With a virile power of "hit,"-

Finished scholar, poet, wit, And good fellow!

Sturdy patriot, and yet

True world's citizen! Regret

Dims our eyes

As we turn each well-thumbed leaf;

Yet a glory 'midst our grief

Will arise.

Years your spirit could not tame,

And they will not dim your fame;

England joys

In your songs, all strength and ease, And the "dreams" you "wrote to please

Gray-haired boys."

And of such were you not one?

Age chilled not your fire of fun.

Heart alive

Makes a boy of a gray bard,

Though his years be, "by the card,"

Eighty-five!

[Bigelow, Jacob.] To a Tadpole. By O. W. H.

Eolopesis: American Rejected Addresses, now first published from the original manuscripts, 1855.

The poems in this volume, which was published anonymously, are parodies, not uniformly successful, of the work of various contemporary poets. The relations between the author and Dr. 


\section{[279 ]}

Holmes were exceedingly intimate. The first two and last three of the thirty-nine stanzas of "To a Tadpole" are here reproduced.

Thou nimble, polymorphous thing,

With limbs within thee bound,

Depending on thy caudal fin

To scull thy body round,

I fain thy character would read,

From signs that thus prevail,

And swear thou hast a waggish head

On such a waggish tail.

And though my hairs are getting thin

And thy short tail is shorter,

We 'll struggle yet a while to keep

Our heads above the water.

And we will sing a brave duet

On life's eventful dream,

And I will make the poetry

And thou shalt make the theme.

And when this planet shall explode,

And send us through the air,

They 'll find our bones in future rocks,

And wonder what they were.

Cluark, George H. A Berkshire Breeze.

Knickerbocker Magazine, April, 1856, vol. 47, pp. 336-340.

Clarke, James Freeman.

Life and Letters of Oliver Wendell Holmes (Morse), 1896, vol. ii, pp. 104-105.

These stanzas were addressed to Dr. Holmes on the eve of his departure for Europe in April, 1886, and were acknowledged by him in a note (printed by Mr. Morse) in which he asks Mr. Clarke to "print these dear lines as my envoi."

May all good thoughts go with thee from this shore,

All kindly greetings mcet thee on the other;

Bring all they can they will not give thee more

Than we send with thee, Poet, Friend, and Brother. 


\section{[280]}

While thou art absent we will say "How often The gloom from off our hearts his smile has lifted;

How well he knew our harder mood to soften, With gleams of sunlight where the storm clouds drifted!

"And how, when that o'erwhelming weight of duty Pressed upon Lincoln's weary hand and brain, Our Holmes's song of tenderness and beauty

Gave that worn heart a moment's rest again!

"Go, then, dear friend, by all good hopes attended;

To mother-England go, our carrier-dove, Saying that this great race, from hers descended, Sends in its Holmes an Easter-gift of love."

\section{Cone, Helen Gray.}

Critic, Oct. 13, 1894, vol. 25, pp. 243-244.

Cranch, Christopher Pearse. To Oliver Wendell Holmes, Et. 70. Read at the Atlantic Breakfast, Dec. 3, 1879.

Atlantic Monthly, Feb., 1880, vol. 45, supp. p. 17 (without title).

Ariel and Caliban, with Other Poems, 1887, p. 169.

A fountain in our green New England hills Sent forth a brook, whose music as I stood

To listen, laughed and sang through field and wood,

With mingled melodies of joyous rills.

Now, following where they led, a river fills

Its channels with a wide, calm, shining flood,

Still murmuring on its banks, with changeful mood.

So, Poet, sound thy stops of various quills,

Where waves of song, wit, wisdom, charm our ears

As in thy youth, and thoughts and smiles by turns

Are ours, grave, gay, or tender. Time forgets

To freeze thy deepening stream. The stealthy years

But bribe the Muse to bring thee amulets

That guard the soul whose fire of youth still burns.

De K[ay], Charles. To Oliver Wendell Holmes.

Critic, Aug. 30, 1884, n. s. vol. 2, p. 100. 


\section{[281 ]}

Dorr, Juila C. R. O. W. H.

Critic, Aug. 30, 1884, n. s. vol. 2, p. 100.

[Sonnet.]

Writer, Nov., 1894, vol. 7, p. 163.

\section{Everett, Willitam.}

Proceedings of the Massachusetts Historical Society, Oct. 11, 1894, 2d series, vol. 9, pp. 161-162.

One poet more, transferred to Homer's train;

One healer more, removed to Galen's side;

One more gold link upon our heroes' chain, -

One friend the less, who never should have died.

Friend, patriot, healer, poet, wit, and sage, -

How hard, how strange, to count him with the past!

We heard his gentle jests on time and age,

Nor dreamed such foes could win the fight at last.

Who for that grave may twine a fitting crown,

Where memory's pansy blends with glory's bay?

Whose pen like his, for ever now laid down,

Tender to feel, and lively to portray?

Yet, while from yonder tower he loved so long Still chime the echoes of his funeral psalm,

Let not the master lack one modest song,

Till bolder hands shall plant some statelier palm.

No single flower that garland can supply,

Such vast and varied springs his genius held,

Whence through a score of channels, never dry,

Fresh, deep, and pure, their shining currents welled.

Sprung from New England's chiefs and saints of yore,

His heart was rooted to her soil alone,

Nor siren charms from lands the ocean o'er

E'er shook his proud allegiance to his own.

Born where our ancient college throws her shade,

He served, he loved her, student to the last;

While o'er her sons in festive ranks arrayed

His genial Muse unfailing fragrance cast. 


\section{[282]}

In love he practised, and in patience taught, The sacred art that battles with disease; Nor stained, by one disloyal act or thought, The holy symbol of Hippocrates.

His lyre through every mood of music rang, The banquet's carol, and the battle's hymn; Now warbling like a child at play, it sang, Now soared to echoes of the seraphim.

Lustrous and leaping, like the Boreal dawn, His wit o'er every theme ranged unconfined; Flashed like a rapier's point in combat drawn, But drew no blood, and left no sore behind.

Wide as our country, wide as England's tongue, Flew his bright name, itself a household word; How frankly proud to all those wreaths he clung, How kindly caught each breath of praise he heard!

Dear were those plaudit notes; but dearer far One treasure, prized o'er all that high renown, Friendship's gemmed circlet, every friend a star, Outshining victor's helm or empire's crown.

So lived, so sang, so talked he; youth's gay beam, Manhood's hot splendor, age's milder glow, Each in its turn might fairest radiance seem, As year by year we watched them shine and go.

Threescore and ten with gentle footstep came, Nor labor pressed, nor sorrow, at fourscore; One lustre more; then rang his summoned name In softest music through Elysium's door.

His bright task wrought, his meed of glory won, His country honored, and his kind improved: Room there is none for tears; yet tears will run, For bard, for master, and for friend removed. 


\section{[283 ]}

Gilder, Richard Watson. August 29, 1809.

Critic, Aug. 30, 1884, n. s. vol. 2, p. 102.

God bless the day! But he hath blest

(And all the grateful world doth know it),

That happy day, when, in the West,

Was born the wise and witty poet -

The poet who first to Science sought,

And to the merry muses after;

Who learned what in no school is taught -

The secret of men's tears and laughter.

Be it, O Time, a weary while,

Ere, in the land where spirits meet us,

A shade shall say (with Shakespeare's smile),

"There comes the Autocrat to greet us."

Gosse, Edmund. An Epistle to Dr. Oliver Wendell Holmes on his Seventy-Fifth Birthday, August 29, 1884.

Critic, Aug. 30, 1884, n. s. vol. 2, p. 102.

Athenæum, Aug. 30, 1884, no. 2966, p. 274.

This poem was also printed separately by Mr. Gosse, in a very limited edition.

Hale, Edward Everetr. Of the Chief - and To Him.

Critic, Aug. 30, 1884, n. s. vol. 2, p. 103.

Harte, Bret. Our Laureate.

Critic, Aug. 30, 1884, n. s. vol. 2, p. 103.

One day, from groves of pine and palm,

The poets of the sky and cover

Had come to greet with song and psalm

The whip-poor-will, - their woodland lover.

All sang their best, but one clear note

That fairly voiced their admiration

Was his - who only sang by rote -

The mock-bird's modest imitation.

So we, who 'd praise the bard who most

Is poet of each high occasion,

Who'd laud our laureate, and toast

The blithe Toast-Master of the Nation, - 


\section{[ 284:]}

To celebratc his fête to-day,

In vain each bard his praise rehearses.

The best that we can sing or say

Is but an echo of his verses.

Heitland, W. E. Lines of Greeting to Dr. Oliver Wendell Holmes at Breakfast in Combination Room, St. John's College, Cambridge [England].

Academy, July 3, 1886, vol. 30, p. 9.

Houghton, LoRd. To Oliver Wendell Holmes.

Critic, Aug. 30, 1884, n. s. vol. 2, p. 104.

Howe, Julia Ward. Lines read at the Holmes Breakfast, Dec. 3, 1879.

Atlantic Monthly, Feb., 1880, vol. 45, supp. pp. 7-8.

Jackson, Helen Hunt [H. H.]. To Oliver Wendell Holmes on his Seventy-Fifth Birthday. Read (by Mr. Warner) at the Atlantic Breakfast, Dec. 3, 1879.

Atlantic Monthly, Feb., 1880, vol. 45, supp. pp. 9-10.

James, Bushrod W. Oliver Wendell Holmes.

Arena, Dec., 1894, vol. 11, p. 55.

Larcom, Lucy. O. W. H. August 29, 1879.

Wild Roses of Cape Ann, 1880.

Locker, Frederick. Dr. Oliver W. Holmes.

Critic, Aug. 30, 1884, n. s. vol. 2, p. 104.

From Boston Town they write to say

Their bard is serenty-five to-day,

And all the world must know it;

But while to him this stare I twine

I wish his birthday could be mine,

And he could be my poet.

Lowell, James Russell. A Fable for Critics.

Poems, Riverside Edition, vol. iii, pp. 84-85.

- To Holmes on his Seventy-Fifth Birthday.

Critic, Sept. 20, 1884, n. s. vol. 2, p. 133.

Heartsease and Rue, 1888.

Mrtchell, Silas Weir. Verses read on presentation of 


\section{[285 ]}

Mrs. Whitman's portrait of Dr. Holmes to the Philadelphia College of Physicians and Surgeons, April 30, 1892.

Boston Medical and Surgical Journal, May 5, 1892, vol. 126, pp. 450-451.

Collected Poems, 1896, p. 344.

Roberts, Charles G. D. Oliver Wendell Holmes. Obiit October 7, 1894.

Dial, Oct. 1, 1895, vol. 19, p. 169.

Roluins, Alice Wellington. The Silent Tribute.

Critic, Aug. 30, 1884, n. s. vol. 2, p. 106.

Sanborn, Franklin B. Dr. Holmes.

Writer, Nov., 1894, vol. 7, p. 161.

Poet and Wit! with heartiest love for man,

Narrowed at first in range, - but wider flowing

When lengthened life unfolded all her plain,

And on his brow mild age was softly snowing.

Smith, Samuel F. Oliver Wendell Holmes. In Memoriam.

Poems of Home and Country, 1895, pp. 109-110.

Stedman, Edmund Crarence. Read at the Atlantic Breakfast, .Dec 3, 1879.

Atlantic Monthly, Feb., 1880, vol. 45, supp. pp. 13-14.

Thомas, Еdiтh M. To Dr. Holmes on his Seventy-Fifth Birthday.

Critic, Aug. 30, 1884, n. s. vol. 2, p. 106.

Trowbridge, John Townsend. Filling an Order. Read at the Atlantic Breakfast, Dec. 3, 1879.

Atlantic Monthly, Feb., 1880, vol. 45, supp. pp. 15-16.

A Home Idyl, and Other Poems, 1881.

Whittier, John Greenleaf. Our Autocrat. Read at the Atlantic Breakfast, Dec. 3, 1879.

Atlantic Monthly, Feb., 1880, vol. 45, supp. pp. 5-6.

—_. To Oliver Wendell Holmes on his Eightieth Birthday.

Poems, Riverside Edition, vol. iv, p. 302. 


\section{$[286]$}

Whittier, John Greenleaf. To Oliver Wendell Holmes. 8th mo, 29th, 1892.

Atlantie Monthly, Sept., 1892, vol. 70, pp. 401-402.

This was the last poem written by Whittier.

Winter, William. The Chieftain. Read at the Atlantic Breakfast, Dec. 3, 1879.

Atlantic Monthly, Feb., 1880, vol. 45, supp. pp. 14-15.

Mr. Winte: gave his poem the title, "Hearts and Holmes," for the occasion, but requested that it be printed as "The Chieftain." 


\section{RECORD OF SALES AT AUCTION}

The following records are taken, necessarily, from the publication called Book-Prices Current, which Mr. Luther S. Livingston has compiled for the past twelve or thirteen years. The volumes included in the record are arranged as in the second division of the bibliography - chronologically. At the end will be found some few memoranda of sales of manuscripts, taken from the same source, and arranged according to the dates of sale. Sales of single works included in the first section of the bibliography are noted in connection with those works. The compiler is much indebted to Mr. Livingston for supplying him with notes of sales for the year 1905-06, before the volume of Book-Prices Current for that year had appeared. The word "sale" after a name indicates that the name is that of the owner of the volume sold; names standing alone are those of the auctioneers, and indicate that the owner's name was not disclosed.

\section{The Harbinger}

Foote sale, 1894, levant

$\$ 15.00$

Bangs, April 1897

Libbie, June 1897

3.50

Libbie, Sept. 1897

Bangs, Jan. 1898

Deane sale, 1898; presentation copy $\quad \mathbf{7 . 0 0}$

Libbie, Nov. 1898

Bangs, March 1899; autograph letter inserted

Roos sale, 1900

Daly sale, 1900

Arnold sale, 1901

Brown Duplicate sale, 1901

French sale, 1901

Libbie, Nov. 1901

Libbie, Dec. 1901 


\section{[288:]}

Libbie, June 1904 (imperfect)

$\$ 4.50$

Anderson, Oct. 1904

10.00

Libbie, March 1905

8.00

Anderson, April 1905

12.00

Anderson, June 1905

4.25

Libbie, Nov. 1905

8.00

Denny sale, 1906

17.00

Merwin-Clayton, Feb. $1906 \quad 9.50$

Pyser sale, 1906

9.50

\section{Poems, 1836}

Foote sale, 1894, $\frac{1}{2}$ mor.; 8 lines of one poem in author's autograph

Libbie, Jan. 1895

Bangs, April 1895

6.05

Bangs, April 1895

8.00

Libbie, Feb. 1897

8.20

Bangs, April 1897; orig. cloth, uncut

Bangs, May 1897; orig. cloth, uncut

16.00

Blanchard sale, 1898

9.00

Bangs, March 1899; autograph letter inserted $\quad \mathbf{7 . 5 0}$

Roos sale, 1900

12.50

Mackay sale, 1900

McKee sale, 1900

14.00

Arnold sale, 1901

23.00

Bangs, Feb. 1901

17.00

Libbie, Nov. 1901

4.25

Bangs, Jan. 1902; autograph letter inserted 21.00

Appleton sale, 1903, levant

Anderson, April 1903

20.00

12.00

Bartlett sale, 1903

15.00

French and Chubbuck sale, $1904 \quad 6.00$

Libbie, March $1904 \quad 7.00$

Stephens sale, $1904 \quad 4.25$

Anderson, May 1904, levant $\quad 10.00$

Anderson, Oct. 1904; autograph of J. S. Dwight $\quad 14.00$

Anderson, Jan. 1905, levant $\quad 15.00$

Knapp sale, 1905

Merwin-Clayton, March 1905

Anderson, March 1905, levant $\quad 21.00$

Libbie, March 1905; with author's autograph $\quad 3.50$ 


\section{[289]}

Anderson, Dec. 1905

$\$ 6.10$

Merwin-Clayton, Feb. 1906

17.00

Merwin-Clayton, March 1906

5.00

Anderson, April 1906

10.10

Barry sale, 1906, morocco

9.80

Merwin-Clayton, May 1906

4.25

Pyser sale, 1906

Poems, 1846 (London)

Foote sale, 1894, mor.; 4 lines in author's autograph $\quad 20.00$

Bangs, April 1896

8.25

Bangs, Nov. 1896

17.50

Libbie, April 1897

5.50

Deane sale, 1898

3.25

McKee sale, 1900

7.00

Arnold sale, 1901; presentation copy to Dr. Morton. with autograph of $\mathrm{O}$. W. $\mathrm{H}$.

47.00

Bangs, Jan. 1902

5.00

Appleton sale, 1903, levant

12.00

Pyser sale, 1906 (rebacked)

Uranta: A Rhymed Lesson

Foote sale, 1894

6.50

Libbie, March 1896

4.50

Libbie, June 1896; autograph note inserted

6.00

Bangs, April 1897

5.00

Bangs, May 1898; presentation copy

4.00

Libbie, Nov. 1898; presentation copy

4.50

Bangs, June 1899; presentation copy

3.00

Roos sale, 1900

3.00

McKee sale, 1900

2.25

Arnold sale, 1901

5.00

French sale, 1901, levant; autograph letter inserted $\quad 40.00$

Bangs, May 1901

3.60

Whipple sale, 1903; presentation copy

6.50

Libbie, Nov. 1904; presentation copy

3.10

Bangs sale, 1905; presentation copy

4.25

Wheeler sale, 1905

3.25

Anderson, Jan. 1906

3.40

Brandon sale, 1906

4.00

Pyser sale, 1906

2.00 


\section{[290:]}

Poems, 1849: first issue

(The copies preceded by an asterisk are those as to which the catalogue stated that they were of the first issue; as to the others no statement was made.)

*Foote sale, 1894, mor.; one stanza of "The Last Leaf" in author's autograph

Libbie, March 1896

$\$ 20.00$

Bangs, April 1896

9.00

Bangs, April 1897

5.50

Libbie, April 1897

7.75

Blanchard sale, 1898

2.50

Libbie, April 1900

4.00

Bangs, May 1900

4.00

*Arnold sale, 1901

4.13

Libbie, Dec. 1901

10.50

Anderson, Oct. 1902

3.50

*Whipple sale, 1903; presentation copy

9.00

*Anderson, June 1905

48.00

Anderson, Jan. 1906

7.50

3.75

*Pyser sale, 1906 ("very fine copy")

1.50

Poems, 1849: second issue

Foote sale, 1894, mor.; autograph letter inserted $\quad 10.00$

Arnold sale, 1901; autograph letter (2 pp.) inserted $\quad 31.00$

Anderson, June 1905; autograph letter inserted $\quad 6.25$

Pyser sale, 1906 (imperfect)

Astrea: the BataAnce of Illusions

Bangs, April 1897

1.50

McKee sale, 1900

1.25

Arnold sale, 1901

1.50

Bangs, Feb. 1901, levant

4.00

Peirce sale, 1903

4.00

Pattee sale, 1905

4.50

Comstock sale, 1906

5.00

Pyser sale, 1906

Poems, 1852 (London)

Arnold sale, 1901

Songs of the Class of 1829 : edition of 1868

Libbie, Oct. 1896

Libbie, Dec. 1896 


\section{[291 ]}

The Address of Mr. Everett, and the Poem of Dr. Holmes, at the dinner to Prince Napoleon, 1861 Foote sale, 1894

Bangs, April 1897

Arnold sale, 1901

Libbie, Dec. 1901

French and Chubbuck sale, 1904; portrait inserted, also autograph letters of Everett and Holmes

12.50

Songs IN Many Keys

Bangs, April 1897

Bangs, April 1897

2.75

McKee sale, 1900

2.50

Arnold sale, 1901

3.00

Whipple sale, 1903; presentation copy

36.00

French and Chubbuck sale, 1904; presentation copy

12.00

Huntington sale, 1905; presentation copy

6.25

Denny sale, 1906

Pyser sale, 1906; presentation copy

3.10

13.00

Songs of Many Seasons

Foote sale, 1894; autograph letter inserted

Arnold sale, 1901

6.50

Pyser sale, 1906

1.75

2.10

A Famir Record

Libbie, March 1896

6.50

Libbie, Sept. 1897

3.50

Arnold sale, 1901

Pyser sale, 1906; autograph letter inserted

Poems, Household Edition, 1877

Arnold sale, 1901

Hurst sale, 1904; presentation copy

The School-Boy

Libbie, April 1897

Arnold sale, 1901

French and Chubbuck sale, 1904; autograph letter inserted

The Iron Gate, and Other Poems

Bangs, April 1897

Whipple sale, 1903; presentation copy 


\section{[292:]}

Alger sale, 1905; presentation copy, with autograph inscription: leaflet, "In Memory of Fitz-Greene Halleck," with author's autograph inserted

$\$ 43.00$

Poems, Handy Volume Edition, 1881: 2 vols.

Pyser sale, 1906; presentation copy

Before the Curfew, and Other Poems

Bangs, April 1897

Arnold sale, 1901; autograph letter inserted $\quad 6.00$

Bangs, Feb. 1901, levant $\quad 9.50$

Whipple sale, 1903

French and Chubbuck sale, 1904; presentation copy $\quad 3.00$

Pyser sale, 1906

3.50

The One-Hoss Shay, etc., 1892

Libbie, Dec. 1901

Carey sale, 1902; autograph poem, signed and dated, on fly-leaf

Pyser sale, 1906

DoRothy Q., etc., 1893

Libbie, April 1895, large paper; autograph letter inserted $\quad 5.50$

Whipple sale, 1903; presentation copy

26.00

Pyser sale, 1906

Poems, Riverside Edition: 3 vols.

Foote sale, 1894; autograph letter inserted

Boylston Prize Dissertations

Libbie, Dec. 1896

3.25

Arnold sale, $1901 \quad 2.00$

Pyser sale, $1906 \quad .25$

Homceopathy, and its Kindred Delusions

Foote sale, 1894

McKee sale, 1900

Arnold sale, 1901; autograph letter (3 pp.) inserted $\quad 22.00$

Peirce sale, 1903

May sale, 1903

4.25

Swan sale, 1904

3.00

Knapp sale, 1905

Pyser sale, 1906

The Contagiousness of Puerperal Fever

Bangs, Jan. 1897

Arnold sale, 1901 (imperfect) 


\section{[293 ]}

Puerperal Fever as a Private Pestillence

Libbie, April 1897

$\$ 3.60$

Blanchard sale, 1898; presentation copy $\quad 4.00$

Arnold sale, 1901

Pyser sale, $1906 \quad 50$

The Position and Prospects of the Medical STUDENT

Libbie, April 1897

Bangs, Sept. 1902

An Introductory Lecture at the Massachusetts

Medical College, 1847

Libbie, April 1897

Peirce sale, 1903

The Benefactors of the Medical School of Harvard University

Arnold sale, 1901; presentation copy to Dr. Bigelow

Oration before the New England Society in NEW YoRK, 1855

Arnold sale, 1901

Valedictory Address to the Medical Graduates of Harvard UNIVERSITY, 1858

Libbie, April 1897

Arnold sale, 1901

Pyser sale, 1906

The Autocrat of the Breakfast-Table: first edition, first issue (with engraved half-title)

Foote sale, 1894, mor.; autograph letter inserted $\quad 25.00$

Bangs, May $1895 \quad 18.00$

Libbie, Jan. $1896 \quad 3.00$

Bangs, March $1896 \quad 6.50$

Libbie, March $1896 \quad 5.25$

Bangs, April $1897 \quad \mathbf{4 . 0 0}$

Libbie, April $1897 \quad 8.50$

Libbie, May 1897

Blanchard sale, 1898

Carruth sale, $1898 \quad 5.00$

Libbie, Nov. 1898; autograph letter inserted $\quad 3.50$

Bangs, April 1899; autograph letter inserted (imperfect) 3.00

Bangs, Oct. 1899 


\section{[294]}

Roos sale, 1900

Mackay sale, 1900

Bangs, May 1900, $\frac{1}{2}$ levant

McKee sale, 1900

Arnold sale, 1901; autograph of one stanza of "The Chambered Nautilus," dated 1892

Bangs, March 1901

Libbie, April 1901

Libbie, Dec. 1901

Bangs, March 1902, $\frac{1}{2}$ levant

Morgan sale, 1902

Bangs, Nov. 1902; autograph letter inserted

May sale, 1903

3.00

Appleton sale, 1903, levant

40.00

Bartlett sale, 1903

3.25

Peirce sale, 1903

8.00

Drowne sale, 1903

French and Chubbuck sale, 1904

6.00

Anderson, Oct. 1904

Anderson, Dec. 1904; autograph letter inserted

Merwin-Clayton, March 1905

Poole sale, 1905

Anderson, June 1905

Harrey sale, 1906

Anderson, Jan. 1906

3.75

Davis sale, 1906

Searing sale, 1906

Burnett sale, 1906; autograph letter inserted

Pyser sale, 1906

The Same: first edition, second issue

Arnold sale, 1901; autograph letter (3 pp.) inserted $\quad 10.00$

Pyser sale, 1906

The Same, 1859: large paper ${ }^{1}$

Bangs, Jan. 1897; presentation copy 10.25

French sale, 1901, large paper; presentation copy $\quad 51.00$

Whipple sale, 1903, large paper; presentation copy with autograph letter inserted

Knapp sale, 1905; autograph letter inserted

${ }^{1}$ A copy on ordinary paper was sold at Anderson's in Jan., 1905, for $\$ 6.50$. 


\section{[295 ]}

Alger sale, 1905; autograph letter inserted (imperfect) $\$ 9.00$ Merwin-Clayton, May 1906

Street sale, 1906

Pyser sale, 1906

The Same, 1860

Pennypacker sale, 1906; presentation copy

The Same, 1893: holiday edition, 2 vols., illustrated by H. Pyle

Libbie, Oct. 1895

Bangs, April 1900

Anderson, April 1900

The Professor at the Breakfast-Table: first edition, 1860

Foote sale, 1894, mor.

Bangs, May 1895

Libbie, March 1897

Bangs, April 1897

6.00

Bangs, April 1899, levant

7.50

Roos sale, 1900

3.25

Arnold sale, 1901; autograph of 3 stanzas of "Under the Violets," dated 1860

French sale, 1901

Libbie, Dec. 1901

Bangs, Jan. 1902

8.00

9.50

Appleton sale, 1902

6.50

Appleton sale, 1903, levant

20.00

Peirce sale, 1903

Whipple sale, 1903

8.00

Whipple sale, 1903; presentation copy, with autograph letter inserted

Libbie, June 1904

Anderson, Oct. 1904

Knapp sale, 1905

Libbie, March 1905

Lemoyne sale, 1905

Pyser sale, 1906

4.75

Peacock sale, 1906

Denny sale, 1906, large paper 


\section{[296:]}

Currents and Counter-Currents in Medical SciENCE

Bangs, May 1895

Libbie, April 1897

Arnold sale, 1901

Hammond sale, 1902; presentation copy to W. A.

Hammond

5.50

Whipple sale, 1903; autograph letter inserted

3.25

Merwin-Clayton, April 1905; autograph letter inserted 3.00

Pyser sale, 1906

Currents and Counter-Currents in Medical ScieNCE, with Other Addresses aNd Essays

Bangs, April 1897

Arnold sale, 1901

Elsie VenNer: first edition, 2 vols.

Foote sale, 1894; autograph letter inserted $\quad 7.50$

Bangs, Nov. 1894

4.00

Libbie, April 1895

5.00

Libbie, March 1896

3.75

Bangs, April 1896

3.50

Bangs, April 1896

4.00

Bangs, April 1897

5.25

Libbie, April 1897

3.75

Libbie, May 1897

4.00

Carruth sale, 1898

3.00

Libbie, Nov. 1898

5.00

Roos sale, 1900

3.25

Mackay sale, 1900

Arnold sale, 1901

Libbie, March 1901

Bangs, April 1901

4.50

Bangs, Dec. 1901

Bangs, Jan. 1902

Bangs, Feb. 1902

Bangs, Oct. 1902

Appleton sale, 1903

Whipple sale, 1903; presentation copy, with autograph letter inserted

Peirce sale, 1903

Cressy sale, 1903 


\section{[297 ]}

Libbie, June 1904

Libbie, March 1905

Merwin-Clayton, Feb. 1906

Pyser sale, 1906; presentation copy

Medical Directions, etc., 1862

Peirce sale, 1903

Border Lines of Knowisedge in some Provinces of Medical Science

Bangs, April 1897

Arnold sale, 1901

Whipple sale, 1903; presentation copy

French and Chubbuck sale, 1904; preseutation copy 14.00

Oration before the City Authorities of Boston, July 4, 1863: regular edition

Bangs, April 1897, $\frac{1}{2}$ calf

Arnold sale, 1901

Lincoln sale, 1901

French and Chubbuck sale, 1904; preface signed by author and 2 autograph letters inserted

The Same. Philadelphia

Hutchinson sale, 1906

The Same: quarto edition, 12 printed

Livermore sale, 1894

Lincoln sale, 1901; presentation copy to F. W. Lincoln, Jr., with autographic inscription ${ }^{1}$

Knapp sale, 1905

The Guardian Angel: first edition

Bangs, April 1897

Arnold sale, 1901; autograph letter inserted

Libbie, Dec. 1901

3.75

Bangs, Jan. 1902

3.25

Whipple sale, 1903; presentation copy

Pyser sale, 1906

Teaching from the Chatr and at the Bedside

Libbie, April 1897

${ }^{1}$ At this same sale a copy of the 4to edition without Dr. Holmes's introductory note (see p. 180, supra) brought only $\$ 7.00$. 


\section{[298]}

History of the American Stereoscope

Arnold sale, 1901

Mechanism in Thought and Morals

Foote sale, 1894; autograph letter inserted $\quad 9.00$

Whipple sale, 1903; presentation copy $\quad 40.00$

Anderson, March 1904; autograph letter inserted $\quad 3.25$

Anderson, April 1904; presentation copy $\quad 6.25$

Alger sale, 1905; presentation copy 21.00

The Claims of Dentistry

Libbie, April 1897

2.25

Arnold sale, 1901

The Poet at the Breakfast-Table: first edition ${ }^{1}$

Foote sale, 1894, mor.

8.75

Libbie, April 1895

9.50

Bangs, May 1895

6.00

Bangs, March 1896

3.00

Bangs, Jan. 1897; presentation copy $\quad 8.00$

Bangs, April 1897

9.00

Libbie, April 1897

3.25

Blanchard sale, 1898

4.75

Libbie, Nov. 1898; autograph letter inserted $\quad 4.25$

Bangs, April 1899, levant $\quad 8.50$

Libbie, May 1899

3.00

Libbie, Feb. 1900

4.12

Roos sale, 1900

3.13

Bangs, April 1900

3.60

Arnold sale, 1901; two autograph letters inserted

French sale, 1901; the C. B. Foote copy (see first entry above)

Libbie, Dec. 1901

Bangs, Jan. 1902

May sale, 1903

Whipple sale, 1903; presentation copy

Appleton sale, 1903

Anderson, April 1903

Somerby sale, 1903

5.25

Anderson, Jan. 1904

Anderson, Oct. 1904

'A "presentation copy" of an edition of 1877 was sold at Anderson's in Jan., 1905, for $\$ 10.00$. 
Alger sale, 1905

Anderson, Jan. 1906

Denny sale, 1906

Brandon sale, 1906

Pyser sale, 1906

Breakfast-Table Series: Autocrat, 1858, Professor, 1860, Poet, 1872 (all first editions)

Anderson, April 1905; autograph letter inserted

57.00

John Lothrop Mothey: first edition

Bangs, April 1897

Bangs, April 1897, large paper

Deane sale, 1898; presentation copy

Daly sale, $1900 ; 57$ portraits and an autograph letter inserted

Arnold sale, 1901, large paper; autograph letter to R. C. Winthrop inserted

Bangs, Jan. 1901

Henkels, Nov. 1902

French and Chubbuck sale, 1904; autograph letter inserted 7.00

Pyser sale, 1906, large paper

Pages from an Old Volume of Life: first edition

Pyser sale, 1906; the Foote copy

Ralph Waldo Emerson

Carruth sale, 1898; autograph letter inserted

McKee sale, 1900; sheets

Arnold sale, 1901

Bangs, Jan. 1901; sheets

Whipple sale, 1903

35.00

Denny sale, 1906; presentation copy to J. S. Dwight Anderson, Jan. 1906; autograph letter inserted

9.00 Merwin-Clayton, 1906; the Denny copy

Pyser sale, 1906; “original pink boards"

12.50

13.00

12.50

A Mortal Antipathy: first edition

Bangs, April 1897

Arnold sale, 1901; autograph letter inserted

Whipple sale, 1903; presentation copy

Pyser sale, 1906

Our Hundred Days IN Europe: first edition

Foote sale, 1894, $\frac{1}{2}$ mor.; autograph letter inserted 


\section{$[300]$}

Bangs, April 1897

$\$ 2.00$

Libbie, April 1897, levant; 54 portraits and plates inserted 7.25

Libbie, April 1897, large paper; autograph letter inserted

Bangs, April 1900; presentation copy, with inscription and autograph note on p. 111

Arnold sale, 1901; autograph letter inserted

Appleton sale, 1903, levant; 54 extra plates inserted

French anri Chubbuck sale, 1904, mor.; 43 plates inserted

Over the Teacups: first edition

Foote sale, 1894; autograph letter inserted

12.00

Bangs, April 1897

Arnold sale, 1901; autograph letter inserted

4.75

Libbie, Dec. 1901

3.00

Whipple sale, 1903; presentation copy

42.50

Bartlett sale, 1903; presentation copy

16.00

Phillips sale, 1906; presentation copy

10.00

Works: Riverside Edition

Bangs, Jan. 1895, 13 vols., large paper

55.25

Bangs, Jan. 1896, 14 vols., large paper

42.00

Bangs, Dec. 1896, 16 vols., large paper

48.00

Bangs, Feb. 1897, 16 vols., large paper

37.60

Henkels, March 1897, 14 vols., large paper

36.40

Bangs, Nov. 1897, 13 vols.

14.95

Henkels, March 1898, 13 vols., $\frac{1}{2}$ levant

48.75

Bangs, April 1899, 16 vols., large paper

64.00

Daly sale, 1900,16 vols., large paper

80.00

Bangs, Nov. 1901, 16 vols., large paper

68.00

Bangs, Feb. 1902; Autocrat, Professor and Poet, 3 vols., with 105 extra portraits and views inserted

19.50

Wales sale, 1903, 14 vols., large paper

66.50

Peirce sale, 1903, 16 vols.,

84.00

Anderson, May 1904, 14 vols., large paper

52.50

Field sale, 1905, 13 vols., large paper

56.00

Works: Standard Library Edition

Henkels, Sept. 1896

14.30

Libbie, Dec. 1896, $\frac{1}{2}$ levant

22.75

Bangs, June 1897, $\frac{1}{2}$ mor.

39.00

Libbie, Nov. 1898, $\frac{1}{2}$ levant

39.00 


\section{[ 301 ]}

Libbie, Jan. 1899, $\frac{1}{2}$ levant

$\$ 32.50$

Bangs, Jan. 1899, $\frac{1}{2}$ mor.

22.50

Libbie, April 1900

19.50

Bangs, May 1900, $\frac{1}{2}$ mor.

26.00

Bangs, April 1901, $\frac{1}{2}$ mor.

26.00

Works: Artists' EDITION

Bangs, May 1895, 13 vols.

24.37

Bangs, Nov. 1895, 13 vols.

58.50

Libbie, Feb. 1897, 13 vols.

22.75

Levy sale, 1903, 3 vols., $\frac{1}{2}$ levant

56.25

Anderson, May 1903, 13 vols.

24.00

Goodwin sale, 1903, 15 vols., levant; autograph letter inserted

Ruppert sale, 1904, 15 vols. in 30, $\frac{1}{2}$ levant

55.50

SoUNDINGS FROM THE ATLANTIC

Foote sale, 1894; autograph letter inserted $\quad 7.00$

Bangs, April 1897

2.25

Arnold sale, 1901

1.12

French sale, 1901

3.00

Bangs, Oct. 1901; autograph letter inserted

8.00

Appleton sale, 1903

3.00

Anderson, April 1905

4.75

Humorous Poems, 1865

Foote sale, 1894

Libbie, April 1897

3.50

Peirce sale, 1903

4.50

Brandon sale, 1906

3.25

Pyser sale, 1906; "original paper covers"

9.00 


\section{$[302]:$}

\section{MANUSCRIPTS}

Dr. Holmes said more than once that his autographs were likely to be so common that they would have little value. The following list seems to prove that he was mistaken; but it should be said that, for lack of space, the compiler has been compelled to omit the record of sales of many letters at prices ranging from $\$ 1.00$ to $\$ 3.00$. They were, in most cases, letters which derived no added value from their subjects or from the eminence of the persons to whom they were addressed. Such notes as the compiler has been able to collect concerning the original mss. of any of Dr. Holmes's works will be found in connection with such works respectively.

Letter of sympathy to James R. Osgood, 1885.

Bangs, March 1896

$\$ 6.25$

Letter of 3 pages, Dec. 29, 1846. “Very interesting personal and literary letter."

Bangs, March 1896

37.00

Autograph ms. of lecture on the Hahnemann Medicinal System, 2 pages.

Bangs, April 1899

Letter of 2 pages, dated Jan. 14, 1886, with 2 stanzas of "The Pilgrim's Vision."

Stryker sale, 1901

Letter unsigned, 2 pages, dated July 3, 1869, to R. C. Waterston.

Arnold sale, 1901

12.00

Letter, 3 pages, dated July 5, 1866, to R. C. Winthrop. Arnold sale, 1901

Letter to Houghton, Osgood \& Co., Oct. 18, 1879, about a sketch of his life being prepared by Ray Palmer.

Arnold sale, 1901

32.50

Letter, 4 pages, dated Dec. 29, 1855, referring to his address before the New England Society, Dec. 23, and discussing his views on slavery.

French sale, 1901

Resold at Bangs's in June 1902, for $\$ 13.00$. 


\section{[ 303 ]}

Autograph stanza, beginning "Iord, let War's tempests cease," 7 lines, signed, dated April 21, 1882.

Bangs, May 1902

$\$ 13.50$

Autograph stanza of "Union and Liberty," 10 lines signed and dated.

Bangs, May 1902

14.00

Letter of 2 pages, dated March 15, 1860.

Peirce sale, 1903

Letter of condolence to John S. Dwight on the death of Mrs. Dwight, 6 pages, dated Nov. 11, 1860.

Alexander sale, 1902

17.00

Letter to John G. Whittier, expressing pleasure at having received an appreciative letter from him, 4 pages, dated March 5, 1870.

Whittier sale, 1903

230.00

Letter to John G. Whittier, 4 pages, dated Oct. 18, 1881, endorsed “ $O$. W. Holmes " in Whittier's hand.

Whittier sale, 1903

60.00

Letter to Edwin P. Whipple, 3 pages, dated Nov. 16, 1880.

Whipple sale, 1903

56.00

Autograph stanza, 4 lines, from the "Army Hymn," signed, dated Nov. 28, 1864. (The hymn was written in 1861.)

Gilsey sale, 1903

Letter to George Bancroft, asking him to read "The Chambered Nautilus," 3 pages, dated Boston, Dec. 1864.

Williamson sale, 1904

Letter to Mrs. Lander, the actress, after seeing a performance of "The Scarlet Letter."

Beck sale, 1905

22.00

Resold by Merwin-Clayton Co. in Oct. 1906, for $\$ 15.00$.

Autograph ms. of the last stanza of "The Chambered Nautilus," signed with full name, and dated July 19, 1890, together with letter of same date, inclosing it.

Wilson sale, 1905 



\section{APPENDIX}

The following pages contain such notes and memoranda as came to the compiler's knowledge only when it was too late to place them where they belong. In one or two instances, place has been made for an important item in the body of the book, by relegating one of less importance to the Appendix.

\section{Page 3}

The "Address for the Opening of the Fifth Avenue Theatre" was spoken by Miss Fanny Morant, down to the passage beginning

"Behold the offspring of the Thespian Cart;"

the remainder by Mr. Frank Hardenberg. It has been printed twice in the publications of the Dunlap Society, viz: -

No. III. Opening Addresses, Laurence Hutton, editor, 1887, pp. 128-133.

No. XII. Occasional Addresses, 1773-1890, L. Hutton and W. Carey, editors, 1890, pp. 102-107.

Page 12

\section{Boston Common}

In the "Boston Common" leaflet, the poem is printed on the inside pages, in facsimile of Dr. Holmes's original ms., signed by him, and dated Nov. 14, 1859. There is a notice of copyright by F. H. Underwood, 1859.

\section{Page 16}

Choose You this Day whom Ye will Serve

Written in 1862, at the request of Rev. Thomas Starr King, of California, "to finish off the lecture he had devoted to me."

Holmes to Motley, Dec., 1862, quoted in Morse's Life and Letters, vol. ii, pp. 170-171.

Page 33.

" "How Came I here?" The Portrait thus might speak"

The following lines were printed in the Boston Medical and 


\section{[ 306 ]}

Surgical Journal, May 5, 1892, vol. 126, pp. 451-452. They were read by Dr. Holmes in reply to the poem with which Dr. S. Weir Mitchell accompanied the presentation of Mrs. Whitman's portrait of Holmes to the Philadelphia College of Physicians.

"How came I here?" The portrait thus might speak,

The crimson mantling in its canvas cheek;

"Here in this concourse of the grave and wise Who look upon me with inquiring eyes,

As on some homeless wanderer, caught astray?

An error loci, Boerhaave would say.

Is this great hive of industry my home?

Where is the Common? Where my gilded dome?

Where the Old South? The frog pond? Most of all,

My sacred temple, Freedom's Faneuil Hall?"

No answer comes; no trick of human art

Can force those fixed, unmoving lips apart.

He whom the picture shadows must explain

This lawless inroad on a strange domain.

Were it $m y$ votive offering, meant to show

My grateful sense of all the debts I owe

To your fair city, its unlooked-for face

Might find no caviller to dispute its place.

Yet though the friendly offering is not mine

It bears my benediction to the shrine

Where, if it meets a welcome, longer yet

Will stretch the column which displays my debt.

Friends of my earlier manhood, ever dear, Whose lives, whose labors all were centred here, How bright each figure stands before me now With eyes undimmed and fair unwrinkled brow, As when, with life before us yet untried, We walked the "Latin Quarter" side by side, Through halls of death, through palaces of pain That cast their shadows on the turbid Seine.

When o'er our coffee, at the old "Procope," Smiling, we cast each other's horoscope, Daring the future's dubious path to scan, Gerhard, your Gerhard was the coming man. 


\section{[ 307 ]}

Strong-brained, strong-willed, inquiring, patient, wise, He looked on truth through achromatic eyes:

Sure to succeed, for Nature, like a maid, Loves best the lovers who are not afraid,

Lends them her hand to lead them where they please, And trusts them boldly with her master-keys. Behold, unfading on the rolls of fame Typhus and Typhoid stamped with Gerhard's name.

Look on the stately form at Gerhard's side. $\mathrm{He}$, too, shall live to be his city's pride. Tall, manly, quiet, grave, but not austere, Not slow of wit, a little dull of ear, Him.we predestined to the place he won, Norris, the Quaker City's noble son.

Armed with the skill that science renders sure, His look, his touch, were half his patient's cure;

What need his merits I should further tell? His record stands; your pages know it well.

Still wandering, lonely, mid the funeral urns, To one loved name my saddening thought returns, Less to the many known, but to the few, A precious memory, - Stewardson, to you. Through many a league we two together fared, The traveller's comforts and discomforts shared.

When hills and valleys parted distant towns, Long ere the railway smoothed their ups and downs. In all the trials wearing days could bring No fretful utterance ever left its sting: Pity it was that, chased by pallid fears, He.walked in shadow through his morning years, Talked of his early doom, and then, and then Lived on, and on, past three score years and ten. Too shy, perhaps too timid, for success, He fought life's battle bravely not the less. Others left prouder memories, none more dear; For those a sigh, for Stewardson a tear!

Well, years rolled on, we went our several ways Not unrewarded with our meed of praise;

Time took the weight and measure of our brains 


\section{[308. ]}

Set us our tasks and paid us for our pains. At length (our side-locks fast were turning gray) He brought our art that all-important day When here our Esculapian Congress met (Its second gathering, you will not forget). I with the crowd your far-famed city sought, Pleased to behold the schools where Rush had taught, Where Wister labored and where Homer led His thinsting flock to Surgery's fountain-head.

What kindly welcome with the rest I shared; A little pleased - perhaps a little scared, When Chapman hugged me in his huge embrace With praise that lit a bonfire in my face When Francis, guest at Mitchell's generous board, My humble name across the table roared, Coupled with one which figures on the roll Of England's poets - bless his worthy soul! Garth - good Sir Samuel, whose poetic spark Scarce seen by day, still glimmers in the dark. These flitting phantoms of the past survive, While grateful Memory keeps her fires alive. Friends of the days that fear and anguish knew My heart records a deeper debt to you.

To this kind refuge hallowed evermore, Her shattered sufferers fond affection bore. Full many a father tracked his bleeding son Fresh from the murderous conflict, lost or won, Strayed through some quiet ward, and looking round, In pity's sheltering arms the lost was found.

Enough! Enough! these eyes will overflow In sweet remembrance of the debt I owe A debt ' $t$ would bankrupt gratitude to pay But Heaven perhaps will hear me when I pray: Peace to your borders! Long may Science reign Supreme, unchallenged o'er her old domain! While sons as worthy as their sires of old Her borrowed sceptre still unbroken hold, Till a new Rush arise who dares to think An unborn LeIDy finds the missing link. 


\section{[309]}

Page 43

\section{Lines written at Sea}

American Monthly Magazine, Feb., 1836, vol. 7, pp. 183184.

Printed in Poems, 1836, under the title "An Evening Thought."

\section{Page 58}

Poem at the Dedication of the Halleck Monument

The pamphlet of 1869 is rare. It was used as copy for a portion of a later pamphlet, printed in 1877 , at the time of the dedication of a memorial to Halleck in Central Park, N. Y.

\section{Page 64}

*A Rhymed Riddle

Fair Words (published in aid of the St. Luke's Home for Convalescents, Florence Street, Boston, at Horticultural Hall, Boston, Feb. 14, 1876), p. 12 (4to, double column).

"I'm going to blank," with failing breath, The fallen gladiator said;

Unconquered, he "consents to death;"

One gasp - the hero soul has fled.

"I'm going to blank," the school-boy cried;

Two sugared sweets his hands display, -

Like snow-flakes in the ocean-tide They vanish, melted both away. Tell with one verb, or I'll tell you,

What each was just about to do.

On the copy in the Boston Athenæum is pasted a tiny slip from the Daily Advertiser, bearing these lines:-

"Succumb," the gladiator groans,

And breathes away his life with moans;

"Suck 'em," the schoolboy cries in glee -

You need n't, Doctor Holmes, tell me. - Sucrer.

Page 68

* Sceptres and thrones the morning realms have tried

The Washington Centenary, celebrated in New York, April 29, 30-May 1, 1889. (Library of Tribune Extras, vol. i, no. 5 , May, 1889.) 


\section{$[310]$}

In the account of the banquet, the thirteenth toast - The President of the United States - to which President Harrison responded, has these lines printed below, motto-wise. They were presumably written for the occasion, but have not been reprinted.

Sceptres and thrones the morning realms have tried;

Earth for the people kept her sunset side.

Arts, manners, creeds the teeming Orient gave;

Freedom, the gift that freights the refluent wave,

Pays with one priceless pearl the guerdon due,

And leaves the Old World debtor to the New.

Long as the watch-towers of our crownless Queen

Front the broad oceans that she sits between,

May her proud sons their plighted faith maintain, And guard unbroken Union's lengthening chain, Union, our peaceful sovereign, she alone

Can make or keep the western world our own!

Page 71

*Song of Welcome

In the pamphlet described, Dr. Holmes's name is not mentioned as the author of the poem. His authorship was first publicly announced in the Annual Report of the Boston School Committee for 1864, p. 202, where the poem is reprinted.

\section{Page 116}

*Tribute to the Memory of Bayard Taylor. Read at a memorial meeting in Boston, Jan. 10, 1879.

Life, Travels and Literary Remains of Bayard Taylor, by R. H. Conwell, 1879 , pp. $325-326{ }^{1}$

The ms. of this address is owned by Mr. S. H. Wakeman.

\section{Page 130}

The Poem for the Dedication of Pittsfield Cemetery was printed with the Address delivered by Rev. Henry Neill on the

${ }^{1}$ In this volume the date of the meeting is not given, and the address is preceded by: "Dr. Holmes's address was nearly as follows." 


\section{[311 ]}

same occasion. The publication containing them is found in the following forms.

1. An Address by Rev. Henry Neill, and A Poem by Oliver Wendell Holmes: Delivered at the Dedication of the Pittsfield (Rural) Cemetery, September 9th, 1850, with other matter, and a Map of the Grounds. By the Committee of Publication. Pittsfield, Mass.: Axtel, Bull and Marsh. . . . Printers. 1850.

In this form the historical summary and proceedings fill pp. 1-22, followed by "Memorials for the Dead" (the Address and Poem), on pp. 23-60; then come 4 pages of miscellaneous verse and a plan of the cemetery. A lithographed plan precedes title.

2. The title-page is the same as in number one, except that the words "with other matter, and a Map of the Grounds" are omitted. The contents consist of the Address and Poem only, on pp. 1-35, the first 3 pages being unnumbered.

Mr. P. K. Foley, to whom I am indebted for the description of number two, advises me that he has a copy (a "presentation copy" from Mr. Neill), handsomely bound, and containing only the Address and Poem, with the pagination of number one, the preliminary matter and the pages beyond 60 having been removed. This would, as Mr. Foley suggests, seem to prove that the longer pamphlet was issued before the other, as $\mathrm{Mr}$. Neill would naturally have chosen for presentation an unmutilated copy if there had been such an one in existence.

\section{Page 180}

Lecture - 1863. Private Copy. Boston, 1863.

4to, blank paper covers; 6 copies printed.

There is no indication of the occasion on which, or of the place where, this lecture was delivered. It is historical in its nature, and opens thus:-

"A great change has taken place within the last two or three years, in the relations of our people and nation to the dynasties of the old world, especially to the predominant power of England. The change is the last of four stages." These stages are - First, Religious Independence; Second, Political Independence; Third, Movement towards Industrial Independence; Fourth, Rapid Growth of Intellectual Independence.

For his knowledge of this and the following item the compiler is indebted to Mrs. J. C. Chamberlain of New York. The copy in the collection of the late Mr. Chamberlain (bound in half- 


\section{[ 312:]}

morocco, original wrappers bound in) has on the first page, in Dr. Holmes's hand: "One of six Copies printed." It brought $\$ 15.50$ at the sale of the library of George Livermore, Esq., in 1894, and was resold by the purchaser, Mr. Chubbuck, at the French-Chubbuck sale in 1904, for $\$ 112.00$.

New England's Master-Key. Boston, 1864.

4to, blank paper covers; 6 copies printed.

Again, there is no indication of the place of delivery of the lecture; but it has at the end a date, Nov. 8, 1864. The theme is the advantage of specialization in making a success of life, and "New England's Master-Key" is defined as the specialization of intellectual labor. After citing examples of persons who devoted their lives to doing one thing thoroughly, - Prescott, Motley, Allibone, Worcester, Webster, Audubon, etc., - Dr. Holmes closes thus: "Nothing has been done in New England that may not be done elsewhere. Take our key, then, brothers and sisters of Kansas, of Florida, of Arizona, and open the gates of progress for yourselves. ... But this mighty nation can never forget its own peculiar task. There is one question in religion; there is one great question in government. The old world has failed to answer either; the new world must try to answer both!"

The late Mr. Chamberlain's copy (half morocco, original covers bound in) bears this inscription on the first page: "One of six copies printed. O. W. Holmes." It brought $\$ 16.00$ at the Livermore sale, and $\$ 110.00$ at the French-Chubbuck sale.

\section{Page 192}

\section{A Mortal Antipathy}

In the opening paper of The New Portfolio, Dr. Holmes said, referring to the founding of the Atlantic: " $I$... wondered somewhat when Mr. Lowell urged me with such earnestness to become a contributor," etc. Whereupon Lowell wrote from London: "The first number of your New Portfolio whets my appetite. Let me make one historical correction. When I accepted the editorship of the Atlantic, I made it a condition precedent that you were the first contributor to be engaged." As a consequence of this " historical correction," when The New Portfolio was issued in book form, as A Mortal Antipathy, 


\section{[313 ]}

the passage quoted was so changed as to read: "I wondered somewhat when Mr. Lowell insisted upon my becoming a contributor." See Scudder's James Russell Lowell, vol. i, p. 413.

\section{Page 255}

Charles D. Meigs, M. D.

The passage on page 113 of Dr. Meigs's book reads thus: -

"Or shall we rather disregard the jejune and fizenless dreamings of sophomore writers, who thunder forth denunciations, and would mark, if they might, with a black and ineffaceable spot, the hard won reputation of every physician, who, in the Providence of God, is called upon to contend with the rage of one of the most destructive of epidemics, and pay an ungrateful service, indispensable to the victims it is allowed to attack, and with the propagation of which they have no more to do than with the propagation of cholera from Jessore to San Francisco, and from Mauritius to St. Petersburg."

See also Copland's Medical Dictionary, 1845, pp. 558-560; and the Fifth Annual Report of the Registrar General of Births, Deaths, and Marriages in England, 1843, pp. 187-189.

In the Memoirs of "Malakoff," Extracts from the Correspondence and Papers of the late William Edward Johnston, edited by R. M. Johnston (London, Hutchinson \& Co., 1907), there is printed a poem called "A Battle-Hymn in Honour of Sir John Heenan," which was printed, soon after the famous Heenan-Sayers prize-fight in 1860, in the New York Times, over the initial "W." This poem is attributed by Mr. Johnston to Dr. Holmes; but the compiler is informed by the editor of the Times that it was written by Mr. Charles Henry Webb, author of Vagrom Verse, etc. 


\section{[314]}

ADDITIONS TO THE CHRONOLOGICAL LIST OF SINGLE PUBLICATIONS

The Autocrat of the Breakfast-Table. With Introduction by G. A. Sala. London, Ward, Lock \& Tyler, 1865.

8vo, pp. iv, 123.

Sixpenny Volume Library.

The Same. London, S. O. Beeton; 1868.

8vo, pp. vii, 279.

The Same. Author's Unabridged Edition. London, George Routledge \& Sons. [1868.]

8vo, pp. iv, 123.

World-Wide Library.

Other editions of the "Autocrat" were issued by Messrs. Routledge in 1884, and 1886 ("Camelot Classics").

Yankee Drolleries. The most celebrated works of the best American humorists. Complete editions, with introduction by G. A. Sala. London, 1870.

3 vols., 8 vo.

The "Autocrat" is included in vol. iii (called "A Third Supply") and the "Professor" in vol. ii. The contents of the volumes range from specimens of Josh Billings to "The Biglow Papers." Each work is paged separately. The paper and press-work are very bad.

The Autocrat, etc. Introduction by G. A. Sala. London, George Routledge \& Sons, 1893. $16 \mathrm{mo}$, pp. 315.

The Same. Introduction by Andrew Lang. London, Ward, Lock \& Co., 1896.

8vo, pp. xx, 331.

XIXth Century Classics, Clement K. Shorter, editor. 
Among their numerous reprints of Dr. Holmes's works, Messrs. Routledge seem to have issued in 1882, and again in 1888, an edition of The Breakfast-Table Series, in 3 "parts," with introduction by G. A. Sala. The issue of 1888 is included in Routledge's Popular Library of Standard Authors.

The Professor at the Breakfast-Table. Selections. With Introduction by H. R. Haweis. London, George Routledge \& Sons, 1886.

16mo, pp. 158.

Routledge's World Library.

The Same. London, George Routledge \& Sons, 1893.

$16 \mathrm{mo}$, pp. 315.

Elsie Venner. London, Routledge, Warne \& Routledge, 1861.

8vo, pp. 428.

"Reprinted from the Atlantic Monthly, where it appeared as "The Professor's Story."”

The Same. London, Routledge, Warne \& Routledge, 1861.

8vo, pp. 376.

Parlour Library, vol. 247.

The Same. Boston, James R. Osgood \& Co., 1869.

8 vo, 2 vols. in 1.

The Same. New Edition. London, George Routledge \& Sons, 1886.

8vo, pp. 148.

The Same. Edinburgh, W. Paterson. [1888.]

8vo, pp. 362. 


\section{[316 ]:}

The Same. London, George Routledge \& Sons, 1890.

8vo, pp. 376.

The Guardian Angel. London, Ward, Lock \& Tyler, 1868.

2 vols., 8vo, pp. 318.

Library of Popular Authors.

The Poet at the Breakfast-Table. London, George Routledge \& Sons, 1872.

8vo, pp. 370.

Reissued in 1884.

The Same. London, John Camden Hotten, $74 \& 75$ Piccadilly. [1872?]

2 vols., 32mo, paper.

The Same. London, Walter Scott. [1889.]

$12 \mathrm{mo}$.

Camelot Series. Uniform with "Autocrat" and "Professor."

The Same. London, George Routledge \& Sons, 1893.

16mo, pp. $315 .^{1}$

A Mortal Antipathy. London, Sampson Low \& Co., 1885.

8vo, pp. 14.

Contains the "Postscript" only.

1 The brief descriptions of the editions consigned to the Appendix are taken from the Catalogue of Printed Books in the British Museum, and the volumes themselves have not been examined. It is noted here as a curious fact that Messrs. Routledge seem to have published in 1893 editions of the "Autocrat," "Professor," and "Poet," each containing 315 pages! 
INDEX 



\section{INDEX}

After Our Hundred Days, 59, 194.

Agnes, 138 n.

Amateur, The, 204-205.

American Academy of Arts and Sciences, Proceedings of, 97, 112, 255.

American Medical Association, 131.

American Monthly Magazine, 24, 31, 41, 55, 64, 309.

Appleton, Thomas G., 92.

Astræa, the Balance of Illusions, 129, 234.

Atlantic Almanac, The, 1868, 113; 1869, 116.

Atlantic Monthly, founding of, 236, 312.

Autocrat, The, Gives a Breakfast to the Public, ms. of, 97.

Autocrat of the Breakfast-Table, The, I (1831-1832), 79, 80, 96.

Autocrat of the Breakfast-Table, The, list of poems in, 96-97;

translation of, 171.

Avis, ms. of, 9, 97.

Battle Hymn, A, 313,

Beecher, Henry Ward, 106.

Benefactors of the Medical School, The, 164.

Berkshire Festival, Lines recited at, sale of, 42.

Bibliographies of Holmes, 245.

Boatswain's Whistle, The, 40, 69.

Border Lines of Knowledge in some Provinces of Medical Science, 178.

Boston Medical Library Association, Holmes Memorial Meeting of, 93, 106; Dedicatory Address, 188.

Brave Old South, The, sales of, 12.

British Museum, catalogue of printed books in, 153, 314-316.

Buckingham's New England Magazine, 16, 17, 19, 32, 36, 39, 47, $60,70,79,80,85,99,117$.

Burns, Robert, 28, 231.

Chambered Nautilus, The, sales of, 15; ms. of, 303.

Childs, George W., 59.

Chimes of Freedom and Union, 206. 


\section{$[320]:$}

Collegian, The, 75, 202-204.

Contagiousness of Puerperal Fever, The, 248 (Cullingworth), 251

(Hodge), 253 (Kneeland), 255, 313 (Meigs).

Cry from the Study, A, 226-227.

Dentistry, The Claims of, 183.

Dickens, Charles, Song for the Dinner to, sale of, 72.

Dorothy Q., 18, 104-105.

Dunlap Society's Publications, 305.

Elsie Venner, translation of, 100, 178.

Ether Controversy, The, 228, 229.

Everett, Edward, Inauguration of, 46; Address of, 89, 137.

Fair Play, sale of, 66.

Fair Words, 65, 309.

Fifth Avenue Theatre, Address for the Opening of the, 305.

Forbes, John Murray, 5, 80, 84.

Gifts of Genius, 10.

Gleaner, The, 205.

Griswold, Rufus W., letter to, 77.

Hall, Marshall, M. D., O. W. H.'s edition of his Principles of the Theory and Practice of Medicine, 199.

Halleck Monument, Poem at the Dedication of, sale of 58, 309.

Harvard Advocate, 33-34.

Harvard Club of New York, Annual Dinner of, 1878, 32, 203.

Harvard Commemoration, 1865, 28.

Heenan, John C,. 313.

Holmes Breakfast, 267.

Homœopathy and its Kindred Delusions, 256.

Inevitable Trial, The, 179.

Iron Gate, The, sale of, 39.

Jackson, Dr. James, 46, 61, 78, 103, 104.

Last Charge, The, sale of, 41.

Last Leaf, The, translation of, 155.

Laurel, The, 206.

Leland, Charles Godfrey, 62. 


\section{[321 ]}

Lessoffsky, Admiral, entertainment of, in Boston, 71, 310.

Liverpool Philomathic Society, 113.

Longfellow, H. W., Journal of, 7, 37, 56, 90.

Lowell, James Russell, 1819-1891 (poem), sale of, 44.

Lowell, James Russell, 49 n, 125.

Lyrics of Loyalty, 206.

“Malakoff," Memoirs of, 313.

Massachusetts Historical Society, Proceedings of, 5, 9, 43, 54, 56, $57,61,96,97,98,99,101,102,103,104,105,107,117,231,235$, 256, 272.

Massachusetts Medical Society, Poem for Centennial Dinner of, ms. of, $58 ; 112,114$.

Medical Highways and By-Ways, 188.

Medical Profession in Massachusetts, The, 182.

Meigs, Charles D., M.D., 313.

Mercantile Library Reporter, 20-24.

Morse, John T., Life and Letters of Holmes, 11, 18, 32 n, 50, 63, $90,92,125,226,236,243,255,256,266,305$.

Mortal Antipathy, A, 312.

Napoleon, Prince, 89, 137.

Naushon Island, 40, 41, 84, 207-208.

New England Society in New York, 69, 108, 164, 229, 230-231, 302.

Old Ironsides, ms. copies of, 51.

Old Player, The, 270.

Our Daily Fare, 36, 60, 229-230.

Our Yankee Girls, sales of, 55.

Over the Teacups, list of poems in, 109.

Pansie (Nath. Hawthorne), 101.

Parkman, Dr. George, biographical sketch of, 164.

Phillips Academy, Andover, 27, 114, 232.

Pictures from Occasional Poems, 1850-1856, 20-24.

Pierce, John, Diary of, viii, 43, 57, 61.

Pittsfield Cemetery, Poem for the Dedication of, sale of, 59; 310.

Poet among the Hills, The, 14, 19, 25, 58, 87, 113, 115, 136, 244.

Poet at the Breakfast-Table, The, list of poems in, 110.

Position and Prospects of the Medical Student, The, 163. 


\section{[ 322 ]}

Professor at the Breakfast-Table, The, 100; list of poems in, 111. Prospective Visit, A, 194.

Punch, poems in, 275-278.

Rabelais Club, 186-187, 234, 270-271.

Sargent, John O., 103, 118, 203.

Scudder, H. E., James Russell Lowell, 236, 313.

Sewall, Harold Marsh, 113.

Smith, J. E. A. See The Poet among the Hills.

Some Stepping-Stones and Stumbling-Blocks in the History of

Medicine, ms., 188.

Sparks, Jared, Inauguration of, 68.

Stafford, Ed., Medical Directions written for Governor Winthrop by, 105, 199.

Teaching from the Chair and at the Bedside, 182.

"This evening hour," etc., sales of, 78.

Token, The, 1831, 43; 1833, 57, 62; 1837, 16; 1838, 53.

Unsatisfied, sale of, 86.

Vanity Fair, caricature of Dr. Holmes in, 252.

Visit to the Autocrat's Landlady, A, sale of ms. of, 52.

Voyage of the Good Ship Union, ms. of, 90.

Washington Centenary, The, 309.

Whitman's, Mrs., portrait of Dr. H., presentation of, to Philadelphia College of Physicians; Dr. H.'s reply to Dr. Mitchell's poem, 306-309.

Whitney, Rev. George, Diary of, viii.

Youth, sale of, 94.

Youth's Keepsake, 17, 26. 
[ 323 ] 
[324] : 
[ 325 ] 
[ 326 ] 
[ 327] 
[ 328 ] : 
[ 329 ] 
[330]: 
[ 331 ] 
[ 332 ] 
[ 333 ] 
[ 334 ] 
[335 ] 
[ 336 ] 
[ 337 ] 


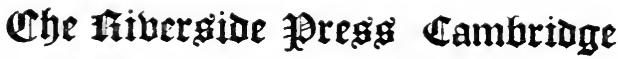


$\underline{\underline{ }}$

A

BIBLIOGRAPHY

OF

OLIVER

WENDELL

HOLMES

\&

IVES 


$$
3,5^{\circ}
$$


